\title{
The Making of Natal: Defensive Institutions and State Formation in Nineteenth Century Southern Africa
}

Jacob Mckinnon Ivey

Follow this and additional works at: https://researchrepository.wvu.edu/etd

\section{Recommended Citation}

Ivey, Jacob Mckinnon, "The Making of Natal: Defensive Institutions and State Formation in Nineteenth Century Southern Africa" (2015). Graduate Theses, Dissertations, and Problem Reports. 5863.

https://researchrepository.wvu.edu/etd/5863

This Dissertation is protected by copyright and/or related rights. It has been brought to you by the The Research Repository @ WVU with permission from the rights-holder(s). You are free to use this Dissertation in any way that is permitted by the copyright and related rights legislation that applies to your use. For other uses you must obtain permission from the rights-holder(s) directly, unless additional rights are indicated by a Creative Commons license in the record and/ or on the work itself. This Dissertation has been accepted for inclusion in WVU Graduate Theses, Dissertations, and Problem Reports collection by an authorized administrator of The Research Repository @ WVU.

For more information, please contact researchrepository@mail.wvu.edu. 
The Making of Natal: Defensive Institutions and State Formation in Nineteenth Century Southern Africa

By Jacob Mckinnon Ivey

\author{
Dissertation submitted to the \\ Eberly College of Arts and Sciences \\ at West Virginia University \\ in partial fulfillment of the requirements \\ for the degree of
}

Doctorate of Philosophy

in

History
Joseph Hodge, Ph.D., Chair
Robert Maxon, Ph.D.
Tamba Mbayo, Ph.D.
Katherine Aaslestad, Ph.D.
Timothy Stapleton, Ph.D.

Department of History

Morgantown, West Virginia

2015

Keywords: South Africa, Natal, British Empire, Africa, Durban, Pietermaritzburg, Theophilus Shepstone, Natal Volunteers, Natal Mounted Police, African Police

Copyright $(2015$ Jacob Mckinnon Ivey 


\begin{abstract}
The Making of Natal: Defensive Institutions and State Formation in Nineteenth Century Southern Africa

Jacob Mckinnon Ivey
\end{abstract}

This dissertation establishes an understanding of how the defensive institutions of the colony of Natal were formed in the context of the emerging British Empire in Southern Africa during the mid-nineteenth century, the parameters of their organization, and their contributions and influences to the institutions which characterized Natal as a colonial state. Paying particular attention to the organization of colonial defence, including the complexities of African contributions to colonial rule and white solutions to questions of security and defence in the emerging colonial state of Natal, a clearer picture of the manner in which Natal defined itself and its place in Southern Africa will be revealed. To accomplish this, particular attention is paid to the structures created during what I have called the "formative period" of the colony; from the Cape Colony's declaring the district of Natal a British territory in May 1844 to the Anglo-Zulu War of 1879. These defensive and military institutions will be revealed as an important pillar in Natal's overall defensive and social structures. These interacting structures of state formation, or "web of structures", illustrate the importance of Natal's creation as a colonial state. Focus is placed on four areas of colonial defence, which evolved over this formative period and helped defined Natal's creation. These include the white volunteer military organization, known collectively as the Volunteer Corps, the European police institutions, paying particular attention to the Natal Mounted Police, the African police constabulary, which worked sometimes in conjunction with and sometimes autonomous from their European counterparts, and finally the Africans who provided a direct military contribution to the colony's defence, or as I have titled them, simply "African military units". All of these organizations acted within the colonial government in one form or another and existed throughout the formative period of the colony. None were part of Her Majesty's formal military forces, and all were almost exclusively composed of residents of Natal, both white and black. The purpose of this limited scope is twofold. It provides an avenue of focus that moves beyond simple regimental histories and gives greater attention to the lives and events of those who took part in colonial defence. Also, by excluding the British Imperial troops, it is easier to strike a balance between both European and African defensive institutions within the colony of Natal. In doing so, my research reinforces the notion that colonial defence was truly a universal concern that included both white and black segments of Natal's society. By focusing on these institutions, tenets of state formation should be recognized, at the same time illustrating the fluid or even amorphous nature of Natal's early development as a colonial state. 


\section{Acknowledgements}

Perhaps one of the most difficult parts of completing a project of this scale is seeing how it has changed and evolved over the years. My first academic exposure to Natal and the Zululand, now KwaZulu-Natal, came from Alan Morris' Washing of the Spears: The Rise and Fall of the Zulu Nation just before the beginning of high school. Admittedly, this was my first exposure to not only Natal and the Zululand, but also the history of South Africa. It provided the catalyst not only for my interest in region, but also the history of apartheid, which was solidified after reading Mandela's Long Walk to Freedom. By the time I began my collegiate career, I knew this nation would dominate my academic interests.

For my Master's degree, I completed my thesis on the Locations System of Theophilus Shepstone, Diplomatic Agent and later Secretary of Native Affairs for Natal (who remains a key figure in this dissertation). The origins of this topic were a combination of two factors. One was the paucity of work that had been done on Shepstone since the 1980s. The other was the relationship Shepstone developed with the African population, particularly those who were impacted by the political turmoil of the early nineteenth century. I was introduced to J.D. Omer-Cooper's work and the wider mfecane debate during my undergraduate by my later Master's advisor, Ezekiel Walker, to whom I remain forever indebted. The administration of the African population, Natal's place in the changing dynamics of the early and mid-nineteenth century, and the manner Shepstone implemented his policy, remained the central focus of my early research.

Yet the importance of colonial Natal remained at the center of my thoughts as I started my PhD at West Virginia University. As I began my early course work, I came to the realization that one of the most interesting, and least developed, components of Natal's formation were the defensive institutions of the colony. The seed for this idea originated with 
Dr. Katherine Aaslestad's "War and Society" course my first year at WVU, where I wrote primarily on the white volunteer institutions within the colony of Natal. However, even within that seminar paper, the interaction and perceptions of the white volunteer corps in conjunction with the African military units under the command of the local magistracy presented a fascinating viewpoint in looking at Natal during its formative period. The extensive correspondence and commentary on Natal's defensive institutions I found in the South African archives solidified in my mind the need for a more nuanced examination of such defensive structures. The result is this dissertation.

This project could not have been completed without so many individuals who helped shape my arguments, academic abilities, and personal sanity. To begin with, Dr. Katherine Aaslestad's course was not only the catalyst for this project, but she has remained a diligent dissertation committee member and has always given me the confidence to move forward with this topic. Her positivity and support helped me to gain the confidence necessary to complete this $\mathrm{PhD}$, and I am eternally grateful to her. Dr. Robert Maxon has been my gateway to developing a deeper understanding of African history, and remains one of the most respectable academics I have had the pleasure to work with. My other committee members, Dr. Tambo Mbayo and Dr. Tim Stapleton were instrumental in the final stages of this project, and to what I hope is a fruitful beginning to my professional career. I would also like to take a moment to thank Dr. Silvermoon, who was only at WVU for the beginning of this process, but who fundamentally helped to shape my understanding of global history. But I cannot say enough about the role that Dr. Joseph Hodge has played as my committee chair, advisor, mentor, and friend. Dr. Hodge was the primary reason I decided to attend WVU and he has been a constant source of support, constructive criticism, and advice these past five years. I look forward to buying him a pint at the Lamb and Flag the next time we are working at Rhodes House. 
I would also like to thank the advisors and researchers who helped me along the path to completing this project. All of the archival staffs in London, Oxford, Edinburgh, and South Africa were very helpful in my research. I would also like to thank in particular the staff at the Killie Campbell Library in Durban and the Pietermaritzburg Depot of the South African National Archives. They were instrumental in assisting with my research, and were very accommodating considering the amount of documents I requested and moved through at what seemed to be lightning speed. I'd also like to thank the other historians who provided advice and assistance during this project, both at home and abroad, including Thom McClendon, Bill Guest, Paul Thompson, and Norman Etherington. A fond thanks goes to T.J. Tallie, who helped with recommendations and research tips for my journey to South Africa. A more somber thanks goes to Dr. Jeff Guy, who sadly passed away the morning of my dissertation defence. This made the defence bitter sweet, knowing he will never be able to read (and rightly critique) my finished work. But his legacy as a historian and teacher, along with the overwhelming contributions he has made to the field, is a gift to everyone who studies the history of South Africa and KwaZulu-Natal.

I had the wonderful opportunity to meet some fantastic friends during my time at WVU. Though I had the privilege of interacting with much of the department while acting as the History Department social coordinator, there are several people I would like to thank who made a strong impact on my time in Morgantown. Steve Santelli, Nick Githuku, Joel Christenson, Kat Fichtel, and Karina and Josh Esposito were wonderful pillars of support my first years in the progam, providing sources of humor, insight, and comradery that enriched my experience overall. Jordan Lieser was not only a great workout buddy, but also a boundless source of insight for my field in Latin America. Billy Feeney, who left Morgantown too soon after my arrival, remains a great friend to discuss teaching methods, classroom troubles, and the proper eating of chicken wings. Adam Zucconi, who I dare say 
spent more time in the office than I did, was a great source of encouragement and an enduring presence during my early dissertation writing in the offices of G13 and G14. Nilanjana Paul was another constant, though perhaps more hectic, presence in the office, and remains a true friend. Fabio Capano and his wife Danielle were wonderful friends during my first years in Morgantown, and continue to be so. Jinny Turman, my Appalachian expert, was also a source of great conversations, and a wonderful graduate social coordinator for the department (who I happily replaced once she graduated). Hal Gorby, my West Virginia and Wheeling expert, has become a great friend and constant source of insightful conversations on politics, teaching, and sports. I'd also like to thank Drs. Ken and Liz Fones-Wolf, who not only provided advice and guidance, but wonderful support during my time in Morgantown, despite my never taking any of their courses. And a final thanks to Joe Rizzo, Brandon Williams, David Goldberg, and Cara Snider, who made me feel like family at times at Copper Beech. Some of my finest memories in Morgantown are watching football games and planning career goals with Rizzo, playing video games and debating pedagogical perspective with Brandon, discussing (or being lectured on) fashion and teaching methods with Goldberg, or comparing recipes and a mutual fondness for Mark Twain with Cara.

Beyond the history department, I cannot thank enough Matt Titolo and Tania De Miguel Magro for their enduring friendship, and providing me a place to stay when I returned to Morgantown for meetings and my dissertation defence, despite our very different fields of study. Thanks also to Lindsey McNellis, who I convinced to move up to Morgantown to become a PhD student in the WVU History Department, but was a dear friend long before, and continues to act as a wonderful source of support for my academic career. Many thanks are also extended to Skip Parrish, who I taught with back at Seminole Community College's Adult High School during my Master's, and who continues to be a great friend. I would also like to thank my dear friend Stephen Ford, who, though in China for the vast majority of this 
process, continued to act as one of my best friends, confidants, and sounding board for ideas, teaching techniques, and random nerd discussions.

And finally, I would like to thank the people who were most impactful to my completion of this project: my family. My sister-in-law Catherine Poulin, and her husband Jimmy, while being great friends, were also wonderful in letting me stay with them for a month in London while I finished the last part of me research at the British Library. My inlaws, Liz and Bruce Anderson, were also very supportive of this process, even when it took me away from their daughter for a year or two. My sister Kelly, brother-in-law Brendan, and nieces Hannah and Elise McNeirney, though never acting as research assistants, did provide many moments of much needed respite from the toils of academia. My parents, Chuck and Liane Ivey, were always supportive of my love of history, including family vacations to history museums, historic sites, and battlefields during my youth. They also encouraged me to travel and see the world, and gave me the support necessary to see London for the very first time. Thank you for all you have done in making me the historian and man I am today. And last, but most certainly not least, I would like to thank my wife, Jennifer Ivey. She has been with me throughout this entire process, and knows the full extent of the trial, turmoil, and triumph that comes with the completion of this project. Four states, three continents, and five years have been nothing but a delight as I have spent the vast majority of it with her. She is my best source of confidence, my most diligent critic, my editor, my research assistant, my travel companion, and my best friend. This project would be nothing without her help and I dedicate it in full to her.

To everyone who has aided in this project, and all the projects to come, I thank you. 


\section{Table of Contents}

ABSTRACT




\section{Chapter One: Introduction}

In 1892, one year before the establishment of responsible government in the colony of Natal, Sir Theophilus Shepstone, former Secretary for Native Affairs and pivotal figure in the history Natal and South Africa, marvelled at what he considered his greatest success:

The history of Natal may be left to speak for itself. Forty-six years of existence, and forty-six years of peace, as far as its internal management in concerned, is a record that no other South African state can show. ${ }^{1}$

One war, and one significant rebellion, though measurable, does little to dissuade this claim. It is not farfetched to postulate that such an extended period of peace directly contributed to Natal's growth as a colonial state throughout the nineteenth century and made it a welcome addition to the Union of South Africa in 1910. Yet the achievement of peace was not as simplistic as summarized by Shepstone. The colony of Natal was part of the British Empire, and its government was the primary implementer of that peace. When considering the maintenance of that peace, the political society of the state, as described by Antonio Gramsci, requires the implementation of force. ${ }^{2}$ Using this logic, the key factor in the organization and implementation of colonial rule has always been the use of force. In terms of implementation, rule was maintained by the negotiation of authority and cooperation of local elites or collaborators, but initially and ultimately, like all states, colonial rule rests on the threat of the use of force. It was through such force or the professed threat of it the British Empire was able to maintain its possessions within Africa, on some fundamental level. Generally, as Robinson and Gallagher illustrated, the "Age of Imperialism" in Africa was not an overarching event dictated by an organized and established plan by the British, but instead

\footnotetext{
${ }^{1}$ Sir Theophilus Shepstone, “The Native Question: Answer to President Reitz,” Reprinted in The Natal Mercury, January 29, 1892, 16.

${ }^{2}$ See Antonio Gramsci, Selections from the Prison Notebooks, ed. Quintin Hoare and Geoffrey Nowell Smith (New York: International Publishers, 1971).
} 
was part of a constantly evolving approach to imperial rivalry with other European states in relation to ministerial questions of where to advance and why. ${ }^{3}$ Therefore, when looking at the formation of particular colonial states within the Empire, especially in Africa, one general thesis concerning the causes of imperial expansion, the reasons for its maintenance, or how it was held together will not suffice. Instead, a more detailed explanation is required to help understand how certain states defended and defined themselves in the period of British settlement and conquest during the nineteenth century. As D.A. Low has illustrated in the case of Uganda, the formation of empire was never set in stone, but instead "fabricated" by the disputes on the ground, leading to unique colonial ventures with their own distinct character and contingency. ${ }^{4}$ Such was the case with the colony of Natal. It would, however, be beyond the scope of this dissertation to provide a comprehensive examination of the "making of Natal", moving through the nineteenth century in the same manner Low moves through late nineteenth and early twentieth century Uganda. Instead, select elements of Natal's formation will be examined. As force and defence were consistent themes in the formation of the Empire across the globe, it is fitting to see how these elements aided in the development of Natal as a colonial state during the nineteenth century.

This dissertation aims to understand how the defensive institutions of the colony of Natal were formed in the context of the emerging British Empire in Southern Africa during the mid-nineteenth century, as well as the parameters of their organization, and their contributions and influences to other institutions which characterized Natal as a colonial

\footnotetext{
${ }^{3}$ Ronald Robinson, John Gallagher, and Alice Denny, Africa and the Victorians: The Official Mind of Imperialism (London: Macmillan, 1961), 13-17.

${ }^{4}$ For Low, the case of Uganda shows a level of "forced amalgamation" which led to the formation of states through a determined process of rule. See D. A Low, Fabrication of Empire: The British and the Uganda Kingdoms, 1890-1902 (Cambridge, UK; New York: Cambridge University Press, 2009).
} 
state. ${ }^{5}$ By paying particular attention to the organization of colonial defence, including the complexities of African contributions to colonial rule and white solutions to questions of security and defence in the emerging colonial state of Natal, a clearer picture of the manner in which Natal defined itself and its place in Southern Africa will be revealed. To accomplish this, close attention is paid to the structures created during what I have called the "formative period" of the colony; from the declaration of the district of Natal as a British territory in May 1844 to the Anglo-Zulu War of 1879.6 These defensive and military institutions will be revealed as an important pillar in Natal's overall defensive and social structures. These interacting structures of state formation, or "web of structures", illustrate the importance of Natal's creation as a colonial state. ${ }^{7}$ By focusing on these institutions, tenets of state formation should be recognized, at the same time illustrating the fluid and even amorphous nature of Natal's development as a colonial state. By using the defensive institutions as a foil, this fluidity, or constant development and change, will become more apparent in the manner in which the colonial government, its citizens, and its subjects attempted to come to grips with the concerns over security and safety within Natal during its formative period.

The very issue of state formation in early colonial or pre-colonial Africa continues to be a crucial question in understanding the role of African states in early colonial systems, whether Zulu, Ndebele, or, more widely, Nguni. ${ }^{8}$ An understanding of the chief system

\footnotetext{
${ }^{5}$ By "defensive institutions", I hope to encompass the civil, military, police, and security components of colonial society under a single term. While "security" could be an alternative, this term illustrates the full scope of these institutions' place in the development of Natal as a colonial state.

${ }^{6}$ The use of the term "formative period" is not only part of the attempt to place a temporal importance to the period of this research. It is during this period that Natal created the major institutions that would define it as a colonial state.

${ }^{7}$ By "web of structures", I mean the interconnected elements of Natal's colonial institutions that would lay the groundwork in defining Natal as a colonial state during this period, an element the defensive institutions were only one part of. These "web of structures" included the colony's military systems, legislature, legal systems, voting practices, indigenous policy, and socioeconomic order, all coming to fruition in some form during this "formative period".

${ }^{8}$ Norman Etherington, "Were There Large States in the Coastal Regions of Southeast Africa before the Rise of the Zulu Kingdom?" History in Africa 31 (January 1, 2004): 157-83.
} 
within Natal will rely on previous analyses of the Zulu chiefdoms during British settlement and following the Anglo-Zulu War of 1879. Though focused largely on the colonial era, such analyses attempt to create an understanding of the impact of the British presence on the institution of chiefship in early colonial Natal. This relates to the standard argument amongst historians of this period about how the British solidified their power base by reestablishing many chiefs who lost influence during the age of Shaka. The role of the chief, however, was significantly altered under the British system. The chief soon became a government official for the British, which undermined African society within the region and in many ways resulted in the collapse of powerbases within the Zulu kingdoms. ${ }^{9}$ All this acted as both a precursor and facilitator in the formation of Natal and its rise as a colonial state in Southern Africa.

A secondary, understated goal of this dissertation will be to show that the eventual incorporation of Natal into South Africa was not inevitable. Whereas previous scholarship has tended to view the history of Natal as part of the backdrop of the larger story of South Africa, the colony deserves independent consideration in its own right. At its core, the response and development of these defensive institutions within the colony shows the fluid and contentious nature of state formation within colonial Natal, and the British Empire as a whole. The need to defend itself, a key hallmark of all states, was an obvious drive and concern for not only the colonial government, but its population. This drive toward selfpreservation in the form of defensive institutions is indicative of a colonial system which envisioned itself as both semi-autonomous and independent from the other colonial entities within British Southern Africa and not of an administration that foresaw its eventual assimilation with the Cape Colony and the rest of what would become South Africa. In

\footnotetext{
${ }^{9}$ For more on the post-Anglo-Zulu War collapse of the Zulu state, see John Lambert, Betrayed Trust: Africans and the State in Colonial Natal (Scottsville, UZA: University of Natal Press, 1995).
} 
essence, the fate of the colony of Natal, with its incorporation into the Union of South Africa in 1910, should not be regarded as inevitable or preordained. Instead, this dissertation will show that the creation of Natal and its development was part of a process of state formation that remained largely autonomous, even when it was an actual dependent of the Cape Colony prior to Natal's Charter in 1856. This autonomous nature is most revealed in the defensive structures which were part of Natal and Natal alone during this period, with little or no overriding influence from the other segments of Southern Africa, especially after the approval of Natal's Colonial Charter. Moreover, Natal should be seen not as an extension of the Cape Colony before union, but instead as a part of the British Empire in its own right. Only then will the history of Natal help to facilitate a greater understanding of its place in the Empire and impact on colonial rule in Africa.

This dissertation will focus on four areas of colonial defence, which evolved over this formative period and helped define Natal's creation. These include the white volunteer military organization, known collectively as the Volunteer Corps; the European police institutions, paying particular attention to the Natal Mounted Police; the African police constabulary, which worked sometimes in conjunction with and sometimes autonomous from their European counterparts; and finally the Africans who provided a direct military contribution to the colony's defence, or as I have titled them, "African military units" or "African military units". All of these organizations acted on behalf of the colonial government in one form or another and existed throughout the formative period of the colony. None were part of Her Majesty's formal military forces, and were almost exclusively composed of residents of Natal, both white and black.

The purpose of this limited scope is twofold. It provides an avenue of focus that moves beyond simple regimental histories and gives greater focus on the lives and events of 
those who took part in colonial defence. Also, by excluding the British Imperial troops, it will be easier to strike a balance between both European and African defensive institutions within the colony of Natal. In doing so, it will become clear that colonial defence was truly a universal concern that included both white and black segments of Natal's society. This will contribute to an understanding of how the defensive institutions of the colony of Natal were formed in the context of the emerging British Empire in Southern Africa during the midnineteenth century, the parameters of their organization, and their contributions and influences to the institutions which characterized Natal as a colonial state.

\section{Historiography}

Despite the lack of a centricity to Natal's important to the history of South Africa within the historiography, there remains a vast scholarship on this particular region of the British Southern Africa. Alan Hattersley's work on the development of colonial Natal during the mid-nineteenth century is widely considered to be the seminal texts for understanding early Natal. ${ }^{10}$ Hattersley's work, though a necessary foundation for any research on early Natal, largely lacks an interpretation of the indigenous policy, as well as an understanding of the manner in which the presence of the indigenous population impacted the Europeans of Natal and their formation of a colonial state. Moreover, because Hattersley represents one of the founding historical accounts of Natal, few have called into question some of his basic research premises. This is beginning to change with the work of scholars like Jeff Guy, who

\footnotetext{
${ }^{10}$ Alan Frederick Hattersley, Portrait of a Colony: The Story of Natal, (Cambridge, UK: University Press, 1940); Alan Frederick Hattersley, The British Settlement of Natal; A Study in Imperial Migration (Cambridge, UK: University Press, 1950); Alan Frederick Hattersley, The Natalians; Further Annals of Natal (Pietermaritzburg,: Shuter \& Shooter, 1940). Hattersley's work, though somewhat dated, is a fantastic source of information for anyone attempting to understand the early history of Natal.
} 
specifically points to Hattersley's dismissal of Lieutenant-Governor Scott and his perceived impact, or lack thereof, on Natal's history. ${ }^{11}$

Hattersley focused largely on the development of Natal during the 1840s and provided an extensive amount of detail in regards to the individuals who initially settled the colony. Hattersley produced a very concise history of Pietermaritzburg, but it is largely a descriptive narrative that focuses on a single location that does not fully address its significance to the wider development of the colony. Other works, including Henderson's and Ingram's urban history of Durban, are local histories commissioned at the end of the nineteenth century to commemorate the fiftieth anniversary of the founding of Natal. ${ }^{12}$ Whereas these works are very insightful, they lack a more nuanced historical analysis of the development of Natal as a colony and more specifically the development of Natal as a colonial state. Hattersley was part a historical tradition which dated back to the beginning of the twentieth century and focused on settler history, political, economic, and military history, and a traditional historical narrative that neglected African involvement in Natal's formation and evolution. Typical examples of this tradition are those studies that examine one of the most famous characters to come out of Natal: Sir Theophilus Shepstone. Both C.J. Uys and J.R. Sullivan were instrumental in creating the early Shepstone narrative, though such works neglect the impact of the indigenous population on the European population, as well as on the colony as a whole. ${ }^{13}$ Similarly, one of the most famous comprehensive histories of Natal can be found in

\footnotetext{
${ }^{11}$ Specifically, Guy points out that though Scott was unable to set the right tone in settler social life, "he did please Professor Hattersley by organizing Christmas parties for children." Jeff Guy, Theophilus Shepstone and the Forging of Natal: African Autonomy and Settler Colonialism in the Making of Traditional Authority (Scottsville, South Africa: University of KwaZulu-Natal Press, 2013), 247.

12 W. P. M. Henderson, Durban: Fifty Years' Municipal History (Durban, South Africa: Robinson, 1904); Joseph Forsyth Ingram, The Colony of Natal: An Official Illustrated Handbook and Railway Guide (London: Sir Joseph Causton and Sons, 1895).

${ }^{13}$ The majority of these works focus on Shepstone's accomplishments during his career, more specifically his work on the annexation of the Transvaal in 1877. C.J. Uys, In the Era of Shepstone: Being a Study of British Expansion in South Africa (1842-1877 (Lovedale, South Africa: Lovedale Press, 1933); J. R Sullivan, The Native Policy of Sir Theophilus Shepstone (Johannesburg: Walker \& Snashall, 1928).
} 
Brookes' and Webb's History of Natal, published the same year as Morris' more famous (at least in the United States) The Washing of the Spears. ${ }^{14}$ Although both were milestones in the field, Morris' work was more of a popular history whereas Brookes and Webb attempted a comprehensive history of what had been an almost completely neglected segment of African history. Both, however, fell victim to the Eurocentric examination of African history, giving little credence or agency to the Africans who formed an important component in this history. Morris' work especially propagated a general misinterpretation of Shaka's regime, which would influence future historiographic debates and interpretations of Shaka's reign. ${ }^{15}$ Both Morris' and Brookes' and Webb's texts were published during the 1960s, a period of transition in African historiography when Eurocentric accounts of African history were challenged by those who wished to give greater agency to Africans during the period of colonization.

Terence Ranger is perhaps the person most responsible for a reexamination of the role of Africans during the colonial period. By presenting Africans with greater agency in their various roles during the period of colonial rule, Ranger illustrated the grander complexity that existed despite the European conquest of Africa. ${ }^{16} \mathrm{He}$ argued that previous historians had misjudged the relationship between rulers and ruled within Africa by contending that the colonial governments were not as strong in their rule and the Africans were not as weak in their subjugation as had been previously presented. Instead, Ranger argued for a greater complexity in understanding the relationship between the resisters and the collaborators, especially in the case of who was more enlightened. Though Ranger's work focused on East

\footnotetext{
${ }^{14}$ Edgar H. Brooks and C. De B. Webb, A History of Natal (Pietermaritzburg: University of Natal Press, 1965); Donald R. Morris, The Washing of the Spears: A History of the Rise of the Zulu Nation Under Shaka and Its Fall in the Zulu War of 1879 (New York: Da Capo Press, 1998).

${ }^{15}$ For the seminal texts of this debate, see Carolyn Hamilton, Terrific Majesty: The Powers of Shaka Zulu and the Limits of Historical Invention (Harvard University Press, 1998); Dan Wylie, Myth of Iron: Shaka in History (Scottsville, South Africa: University of KwaZulu-Natal Press, 2006).

${ }^{16}$ See T. O. Ranger, "African Reaction to the Imposition of Colonial Rule in East and Central Africa," in The The History and Politics of Colonialism in Africa, vol. I (Cambridge: Cambridge University Press, 1969).
} 
and Central Africa, it would have a lasting influence on historians of South African, perhaps most notably J.D. Omer-Cooper and Shula Marks.

J.D. Omer-Cooper provided the basis for the mfecane thesis, which became a staple of the historiography of nineteenth century South Africa. The thesis essentially states that during the precolonial early nineteenth century, the Zulu kingdom initiated a "crushing" or "scattering" of Nguni people across Southern Africa that resulted in a period of migrancy and increased state-building throughout the subcontinent, and which included the formation of the Zulu nation. These migrations and transformations also influenced the trajectory of African groups like the Sotho, Swazi, and Ndebele. ${ }^{17}$ Though Omer-Cooper's work and the mfecane thesis has been a major point of contention within South African historiography, his work is widely considered by many in the field to be a celebration of the revolutionary changes which took place in the Zulu kingdom following the turmoil, and its longstanding influence on African history. Marks, in her own right, took a more revisionist analysis of the Bambatha Rebellion of 1906, illustrating the principle causes of the rebellion were aimed more against the imposition of a "Poll Tax" than a simple rebellion against white authority. It so doing, Marks provided a deeper understanding of African agency during the colonial period, a first for a historian of Natal. ${ }^{18}$

Marks was also a critical figure in challenging the old Eurocentric patterns of Natal's history, specifically calling into question the works of Brookes and Webb, by claiming that their history of Natal was heavily biased "towards the history of white settlement in Natal" and appeared "cut off from the new thinking in their field", using Omer-Cooper as a key

\footnotetext{
17 Though the mfecane thesis remained a major source of debate, it continues to act as an importance catalyst for South African historiography. J. D. Omer-Cooper, The Zulu Aftermath: A Nineteenth-Century Revolution in Bantu Africa (Evanston, Ill: Northwestern University Press, 1966).

${ }^{18}$ Shula Marks, Reluctant Rebellion: The 1906-8 Disturbances in Natal, Oxford Studies in African Affairs (Oxford: Clarendon Press, 1970).
} 
counterpoint. ${ }^{19}$ Such criticism was the starting point for a new generation of young scholars who began examining the deeper cultural elements of Natal and African society during the nineteenth century. Despite the internal debates in South African historiography, particularly the divide over the "Radical-Liberal Debate" of the $1970 \mathrm{~s},{ }^{20}$ historians of Natal continued to focus on a more insightful analysis of the evolution of Natal and its people during the late nineteenth and twentieth century. From this wellspring, new topics of analysis, including missionaries, urban organization, and African intellectuals, have appeared over the last quarter of the twentieth century. ${ }^{21}$ The most prolific and influential product of this new wave of research was the volume on Natal and Zululand history published 1989, that included a reinterpretation of the archaeological records, and new analyses of state formation and of the inherent links between white supremacy and black impoverishment in Natal at the turn of the twentieth century. ${ }^{22}$ Other works from this new wave of historians focused almost exclusively on Africans and Natal and helped to fill the gap in the historiography with quality scholarship. This dissertation has been inspired by many of these works. ${ }^{23}$

\footnotetext{
${ }^{19}$ Shula Marks, "The Nguni, the Natalians, and Their History," The Journal of African History 8, no. 03 (1967): 529.

${ }^{20}$ The 'Radical-Liberal' debate emerged when a group of 'radical' historians from Britain challenged the 'liberal' stance of many South African historians that the roots of white racism lay in the frontier experience of the Afrikaner. Instead, these 'radicals' argued from a Marxist perspective that racial divisions were the result of class conflict. This debate fit within the larger divide that existed during the 1970s between economic Marxism and traditional empirical history, but the work from this period in Natal does not reflect this conflict. For more on this debate, see Christopher Saunders, The Making of the South African Past: Major Historians on Race and Class (Totowa, N.J: Rowman \& Littlefield Publishers, 1988).

${ }^{21}$ See Norman Etherington, Preachers, Peasants and Politics in Southeast Africa, 1835-1880: African Christian Communities in Natal, Pondoland and Zululand, Royal Historical Society Studies in History Series, no. 12 (London: Royal Historical Society, 1978); Bill Guest and John M. Sellers, Enterprise and Exploitation in a Victorian Colony: Aspects of the Economic and Social History of Colonial Natal (University of Natal Press, 1985); John Lambert, Betrayed Trust: Africans and the State in Colonial Natal (Scottsville, UZA: University of Natal Press, 1995).

${ }^{22}$ Andrew Duminy and Bill Guest, eds., Natal and Zululand from Earliest Times to 1910: A New History (University of Natal Press, 1990).

${ }^{23}$ Lambert, Betrayed Trust; Jeff Guy, The Destruction of the Zulu Kingdom: The Civil War in Zululand, 18791884 (Pietermaritzburg [S. Africa]: University of Natal Press, 1994); Jeff Guy, The View Across the River: Harriette Colenso and the Zulu Struggle Against Imperialism, Reconsiderations in Southern African History (Charlottesville, Va: University Press of Virginia, 2002).
} 
Yet perhaps one of the most fascinating elements of the historiography is the analysis of Theophilus Shepstone who defined nineteenth century colonial Natal, for better or worse. Although much of the early work by Uys and Sullivan focused on the formation of Shepstone's system, there is little emphasis on his adoption of indigenous tactics in managing the African chiefs of Natal. ${ }^{24}$ With the publication of David Welsh's The Roots of Segregation, the literature began to present Shepstone's actions in Natal as the roots of apartheid institutions in South Africa. ${ }^{25}$ The problem with this, as Jeff Guy explains, is that Welsh's work was structured thematically, leading to a misleading continuity and consistency in Shepstone's actions in Southern Africa. ${ }^{26}$ Over the last decade, however, there has been a shift in focus on tactics for administrative and colonial control, providing deeper insight in understanding the policy of Shepstone. ${ }^{27}$ Thomas McClendon has made great strides in providing a weightier analysis of Shepstone's activity in what I have termed the formative period of Natal. His examination provided a collection of thoroughly researched and presented case studies which illustrate Shepstone's methods of control and interaction with the indigenous population. Similarly, Jeff Guy's most recent work on Shepstone has produced one of the most detailed accounts of Natal's formative period in recent history. Systematically analysing Shepstone's activities in the colony beyond simple biography, Guy attempts to fully contextualize Shepstone's ideas and arguments, creating a deeper understanding of Shepstone, his policies, and his times. ${ }^{28}$ It is this type of analysis which provides the most important inspiration and influence for this work. Though the actions of Shepstone are not the only reason for Natal's development as a colonial state, the fluidity of

\footnotetext{
${ }^{24}$ A more detailed analysis of the Shepstone system will be provided in Chapter One.

${ }^{25}$ David Welsh, The Roots of Segregation; Native Policy in Colonial Natal, 1845-1910 (Cape Town, New York: Oxford University Press, 1971).

${ }^{26}$ Guy, Theophilus Shepstone and the Forging of Natal, 9.

27 Two examples include Thomas V McClendon, White Chief, Black Lords Shepstone and the Colonial State in Natal, South Africa, 1845-1878, Rochester Studies in African History and the Diaspora, v. 46 (Rochester, NY: University of Rochester Press, 2010); Guy, Theophilus Shepstone and the Forging of Natal.

${ }^{28}$ Guy, Theophilus Shepstone and the Forging of Natal, 5.
} 
his indigenous policy compared to colonial states during the later period of imperialism and its role in Natal's growth during this formative period were an important component in the development of Southern Africa, and the British Empire.

Colonial Natal should be situated not only within the history of Southern Africa but also within the British Empire. For this reason, this dissertation will attempt to come to grips with the growing field of the "New Imperial History". Over the past quarter century, in light of the "cultural turn" in the field of history more generally, the field of imperial history has witnessed a vast interdisciplinary expansion, which has challenged "Western" modes of thought, by examining the world from a global perspective. This can clearly be seen in multiple disciplines, from history, sociology, and literature, including research in the British Empire. Known as the "Imperial Turn", there was a pronounced shift away from the study of domestic and national history toward a study of empire, integrating domestic British history with the history of Britain overseas. This "turn" complicated the presumed territorial, cultural, and political boundaries between empire and nations and has resulted in a new wave of scholarship which is more inclusive of those ruled within the British Empire and also more focused on the peripheries of empire. As Kathleen Wilson has stated, the New Imperial history represents works of "historical analysis that are geared to doing precisely what [historians] themselves acknowledge to simultaneously be impossible...to recognize alternative modes and sources for understanding the past, to probe the limits of historical knowledge, and to make the 'subaltern'-from indigenes to women, and all others rendered silent or invisible by the historical archive- 'speak." ${ }^{29}$ To accomplish such a goal, many historians of imperial history have moved beyond the official archives and instead "focused more on the cultures of empire and on language, and [are] dependent on poststructuralist

\footnotetext{
${ }^{29}$ Kathleen Wilson, "Introduction: histories, empires, modernites" in Kathleen Wilson, ed., A New Imperial History: Culture, Identity and Modernity in Britain and the Empire, 1660-1840 (Cambridge, UK: Cambridge University Press, 2004), 2.
} 
ideas in which discourses, narratives, and representations were as important as material 'realities"." ${ }^{30}$ With this turn, imperial studies have moved toward globalization and postcolonial studies. This new scholarship, though very telling about Britain (especially England and Scotland), is less informative on Africa, Asia, or Latin America. Though less influenced by the postcolonial approach of the New Imperial History, especially its emphasis on culture and language, this dissertation will nevertheless attempt to create a hybrid methodology of empirical data, cultural analysis, and political and social commentary for Natal and Africa. Though not defined by these theories, this dissertation shares the desire of many new historians of empire to move beyond the "official" archives and embrace the variety of fields and alternative sources available to scholars.

Perhaps just as important, this dissertation will examine the importance of war and society in colonial Africa. Although only one widespread conflict, the Anglo-Zulu War of 1879, will be covered, the importance of war as an abstract phenomenon plays an important role in the formation of Natal. Roger Chickering acknowledged over a decade ago that "military history has largely escaped the methodological assaults that have been launched in the name of the "linguistic turn"”, but the study of war and society has quickly turned to emphasize the various ways war and militarism influenced society and civilian life, both at home and abroad. ${ }^{31}$ This wave of historical military analysis has moved beyond the simple purviews of "military history" and instead provided a more nuanced examination of the manner in which militarism influenced and directed social and political movements during the modern period. As Jeremy Black has written, military history should be understood

\footnotetext{
${ }^{30}$ Ghosh has recently produced a wonderful summary of the New Imperial Histories which acts as an introductory primer to this historiographic movement. See Durba Ghosh, "Another Set of Imperial Turns?," The American Historical Review 117, no. 3 (June 1, 2012): 785.

${ }^{31}$ Chickering uses this premise as the basis for his interpretation of "Total War", though he challenges the master narrative it provided historians for much of the twentieth century. See Roger Chickering, "Total War: The Use and Abuse of a Concept" in Manfred F. Boemeke, Roger Chickering, and Stig Förster, eds., Anticipating Total War: The German and American Experiences, 1871-1914 (Cambridge: Cambridge University Press, 1999), 13.
} 
through the approach of "military organisation" as an aspect of "wider social patterns and practices" and the systemisation of knowledge that assists in understanding "the military, its activities and its interactions with the wider world." 32 Colonial military history, in particular, has benefited from this transition to perhaps the greatest degree, providing new avenues for research and analysis from multiple angles of empires across the globe. Colonial wars, states of emergency, civil disturbances, or rebellions, despite their categorization by some as "small wars" or pacification, provide an opportunity for research not only in the study of war, but also in the social consequences of those conflicts on the individuals and communities, both white and black, involved. ${ }^{33}$

These "small wars" provide historians the means to address the wider topics of war and society, particularly the social and cultural impact of conflicts. One example is Jan-Bart Gewald's examination of the manner in which the Herero and their military actions moulded their society in the wake of a genocidal colonial war, fundamentally changing their politics and social order. Though Gewald's book is not centrally focused on the Herero-German War of 1904-1908, he uses the backdrop of the war as a means of understanding how the Herero "grappled to maintain and attain control over their freedom, and how, when they lost this, they reorganized to continue their struggle toward redemption." ${ }^{34}$ Another example of the use of war and society comes from Isabel Hull's work, also an examination of German West Africa. Hull, however, uses colonial warfare to provide evidence for her conclusion that

32 Jeremy Black, "Military Organisations and Military Change in Historical Perspective," The Journal of Military History 62, no. 4 (October 1, 1998): 871-872.

${ }^{33}$ The early twentieth century writer on colonial war Colonel Callwell defined colonial wars as "small wars" not because of their scale, but because of the nature of the opponents to European forces. Caldwell presented one of the two major schools of thought for colonial wars in the early twentieth century, the other from French writers such as Gallieni and Lyautey. The primary difference in these two schools revolved around the implementation of force, in which troops could be used as a force of intimidation or of protection and a symbol of progress among the indigenous people. The use of force was only used when necessary and in doing so, as Lyautey would attest, "with pacification a great wave of civilization spreads out like an oil slick." See H. L. Wesseling, Imperialism and Colonialism: Essays on the History of European Expansion (Westport, Conn: Praeger, 1997), 5-6.

${ }^{34}$ Jan-Bart Gewald, Herero Heroes: Socio-Political History Of Herero Of Namibia, (Athens, Ohio: Ohio University Press, 1999), 9. 
imperial Germany's political and military culture facilitated the reckless approaches that contributed to genocide, both by the Germans in Namibia and the National Socialists at home decades later. Using the Herero genocide as the prime case study, Hull connects the necessities on the ground in Southwest Africa to the German military culture. Hull argues it was this culture which resulted in military atrocities against the Maji-Maji in modern Tanzania, the Boxers in China, and finally in Europe, where it was defined by an "immediate propensity for extreme violence, its deadly instrumentalization of civilians, and its tendency when thwarted to repeat its scripts of violence to the point of self-destruction". ${ }^{35}$ Though controversial, both of these historians illustrate the ways war and society in a colonial setting can be incorporated into a richer analysis of both the colonized and the colonizer during the nineteenth century.

\section{Statement on Research and Outline}

The development of Natal as a colonial state is a fundamentally important topic in the history of the British Empire in South Africa. Not only is Natal the birthplace of many African National Congress and anti-apartheid leaders of the twentieth century, it also holds a distinctive place in the emergence of British colonial rule in Africa. Because of this, Natal deserves to be examined in its own right outside of the development of the Cape Colony, the Orange Free State, and the Transvaal, and not as a "backwater periphery" to these other sections of South Africa. The mid-nineteenth century was a period of major change within Africa and the British Empire. Predating the "Scramble for Africa" and the creation of formal colonial rule in many parts of the Sub-Saharan Africa, the actions taken by the British and their interaction with the indigenous populations of Southern Africa in the mid-nineteenth

\footnotetext{
${ }^{35}$ Isabel V. Hull, Absolute Destruction: Military Culture and the Practices of War in Imperial Germany (Cornell University Press, 2006), 4.
} 
century acted as a forerunner to subsequent colonial conquests in the late nineteenth and early twentieth century. This project will attempt to place Natal within that period of change.

To accomplish this, questions will be asked concerning the manner in which Natal was formed as a colonial state, specifically in regards to the institutions of defence and military organization. How does Natal's military develop during this period? What role did Africans play in the formation of the military and police forces within the colony? How important was land and the defence of land to the colonists and Africans within Natal? What were the central debates between the European colonists, Africans, and the colonial government? How were these debates articulated and what impact did they have on policy? What role did the policy toward indigenous Africans play in this overall state formation?

Extensive focus has been placed on the relationships between defensive institutions, the people who took part in them, and the emergence of the colonial government which formed and solidified during this period. Generally speaking, the means through which one establishes such connections rests largely on the reports generated from both the press and colonial governments. In a few cases, court and legal records have provided a view into the mind-set of the police, volunteers, and troops who helped forge Natal into a colonial state. This dissertation has made extensive use of colonial documents from both Britain and the colony, as well as the vast array of press opinions available. With that in mind, this project has taken a page out of Dane Kennedy's book and created a sort of overlap between postcolonial studies and imperial history, in which cultural history and discourse analysis are used in conjunction with empirical research on empires. ${ }^{36}$ Combining the information found in the colonial archives in both South Africa and London, the empirical data backs the

\footnotetext{
${ }^{36}$ Kennedy thoroughly examined the development of imperial history and its incorporation into postcolonial theory. While somewhat critical of postcolonial theory, Kennedy sees the benefits of its incorporation into Imperial history as well as the "New Imperial History". Dane Kennedy, "Imperial History and Postcolonial Theory," Journal of Imperial and Commonwealth History 24, no. 2 (2001): 131-41.
} 
conclusions asserted about Natal's formation as a colonial state. Government documents, agent correspondence, court statements, and newspapers provide the basis for much of this research. While reading "against the grain" in most of these archives, problems of bias still exist in the majority of these political accounts. But the rich case studies that can be found in such accounts still reveal the exceptional place of Natal in the formation of Southern Africa and the British Empire. Unfortunately, such resources also limit the subaltern voice, and result in partial interpretations or limited analysis.

The challenge of the "indigenous voice" remains one of the key obstacles for historians of the early colonial era in Africa. Written records by Africans are difficult, if not impossible, to come by, and those that are available present an even greater complexity to historians. Though some Africans were tutored by Bishop John Colenso and other missionaries in Natal during this formative period, few of them have left any extensive written records. ${ }^{37}$ The silences that occur in many colonial records and the limited recordings of the African voice have influenced the presentation of the indigenous population within the dissertation. Some elements of oral history do exist, either in depositions or interviews, particular the James Stuart Archives. ${ }^{38}$ These were used when available and relevant. By using this combination of methodologies, this dissertation makes a relevant contribution to the role of African and European agency and resistance and collaboration within Natal during its formative period. It will also illuminate the relationships which developed between

\footnotetext{
${ }^{37}$ Hlonipha Mokoena's book on Magema Fuze, the first African to publish a book in Zulu, does illustrate how some early African writers. Mokoena's work, though insightful and informative, is somewhat limited considering the publication of Fuze's book in 1920, but it still remains a critical component in understanding the growth of Zulu intellectualism; Hlonipha Mokoena, Mugema Fuze: The Making of a Kholwa Intellectual (Scottsville, UZA: University of KwaZulu-Natal Press, 2011).

${ }^{38}$ The James Stuart Archives is an invaluable tool for historians of Natal. A printed version of the James Stuart Collection exists at the Killie Campbell Africana Library in Durban. The archives provide an extensive collection of oral histories taken by the colonial administrator James Stuart at the turn of the twentieth century. Though a point of contention from some historians of Natal because of the supposed unreliable nature of Stuart's recording, the archives continue to be a primary tool for finding the "African voice" in the history of pre-colonial and colonial Natal. For the history of the archives, see John Wright, "Making the James Stuart Archive," History in Africa 23 (January 1, 1996): 333-50.
} 
European, Afrikaner, and African military and police institutions and how they were indicative of a developing state attempting to come to grips with problems of security, stability, and safety within a colonial setting.

This dissertation will begin with a brief summary of the history of Southern Africa that helps contextualize the place of Natal within the emerging British Empire of the nineteenth century. But beginning with the Volunteer Corps (Chapter Three), this dissertation will chronologically move through the history of Natal during its formative period. Government regulations between the enactment of the Volunteer Law of 1854 and the Volunteer Regulation Act of 1877 will illustrate the evolving nature of defence within the colonial state, as well as legitimate concerns for the issue of security, especially in response to the continuing influx of an indigenous population that estimates placed between 80,000 and 120,000 by $1845 .{ }^{39}$ Though the European population would make use of the volunteer system not only as a means of collective security, but as an instrument of power within the colonial state, the formation, preservation, and continuation of these volunteer systems would be consistently challenged, dismissed, and even abolished by members of the colonial government, the press, and citizens of the colony who had their own plans and suggestions of how the colony should defend itself. Ironically, despite the shortcomings of many components of this system, the volunteer corps would remain one of the most enduring and praised aspects of Natal's security institutions for much of its formative period.

Within fifty years of its founding, Natal had also established a police force that became a critical element in its internal security and fully established itself as a "pillar" of colonial authority. The origins of this system can be found in the formative period. The analysis of the European police institutions (Chapter Four) will attempt to address how the

39 The population well exceeded 100,000 by 1852, see "Population", Natal Blue Books, 1852. 
police and law enforcement systems within Natal acted as a key example of a society attempting to come to grips with the questions of security and safety which continued throughout the formative period of the colony. Though the Natal Mounted Police, and later the Natal Police, would normalize the level of discipline, consistency, and legal fairness in the police system of the colony following the Anglo-Zulu War, concerns of expense, security, racial divisions, and the extent of violence and criminality within the colony were all facilitated during this formative period.

Although the perceptions of control and security within Natal would be dominated by the white European pillars of defence, it was the Africans who provided perhaps the most striking and vital element of colonial security during the formative period of the colony. These African institutions would take the form of the police and the military establishments that were directed by colonial administrators, including the local magistracy and white officers. The last two chapters will in turn focus on the African police and military institutions during this formative period (Chapter Five and Six). Much like the white police and volunteer institutions of the colony, the African population was a component of colonial defence that elicited debate, apprehension, and a sense of fear which permeated Natal's public consciousness. Yet, by delving into the formation, organization, and responses to colonial violence the Africans experienced in the colonial constabulary, a deeper understanding of African agency in the formation of Natal as a colonial state will be revealed, indicative of a fluid state system of control that was characteristic of Natal. This will remain essential to understanding the imperial structures of defence that were common in the nineteenth century. Much like the chapter on African police, the next chapter on African troops (Chapter Six) will attempt to address the impact of indigenous military units on the security and organization of the British colony of Natal. The importance of these indigenous military units on the safety and security of the colony is undeniable in the broader 
examination of the colony's history, yet questions remain on how these units were organized within the colonial system, what their origins were in the formation of the colony, how they were perceived by European colonists, and in what manner the military institutions change during this period. Whereas it is clear that there was indigenous involvement in the security apparatuses of the colony, such participation not only advances the theory of a type of militarization of society that took place in Natal during this period (a type of militarization in which colonial apprehension was one aspect of the overarching idea of colonial security) but also provides a viable platform for incorporating African agency into the administration and creation of Natal as a colonial state.

By looking at these elements or pillars of colonial security, a more nuanced analysis of the history of Natal's defensive institutions will be revealed. This study meets the criteria of what Antoinette Burton defines as critically engaged historical scholarship, which "aims to trouble conventional narratives and exhilarates in the shifting ground of historical production itself'. ${ }^{40}$ The narrative to this point of the military development of Natal has been little more than regimental histories. The grounds of historical production have also examined either Africans or Europeans as exclusively independent from one another, instead of a form of collaboration during the formation of a colonial state. To fully understand how Natal was formed as a colonial state, an inclusive examination of the major institutions of colonial defence, both white and black, is critical in presenting a more compelling account of the making of Natal.

\footnotetext{
${ }^{40}$ Antoinette Burton, At the Heart of the Empire: Indians and the Colonial Encounter in Late-Victorian Britain (Berkeley: University of California Press, 1998), 14.
} 


\section{Chapter Two: British Southern Africa and Natal in the Nineteenth Century}

For historians of Africa, context, and the ability to properly situate such context, is a critical component in the formation of historical ideas. Without such context, it would be difficult to gauge the parameters and importance of Natal's place in the British Empire, and the influences of its defensive institutions on the emerging South African state in the nineteenth century. With this in mind, the following chapter will attempt to address the emergence of British and Afrikaner power in the region during the nineteenth century, the formation of imperial policy in Southern Africa, and the state of imperial rule during Natal's formative period. The chapter will conclude with a brief history of the colony of Natal and an analysis of the key debates during this period with the aim of situating Natal's defensive institutions within the wider history of nineteenth century Southern Africa.

For historians of South Africa, the emergence of colonial rule is one of the most basic tenants in understanding South Africa's unique place within the British Empire and its political and social origins. To better understand the emergence of Natal and its creation as a colonial state, the context of its surroundings and the influences of policies from other parts of South Africa must be established. As Crawford Young argues, the colonial state achieved a "distinctive personality of its own" after the colonial polity began expressing itself in the same process as its modern British counterpart. ${ }^{1}$ To understand the "distinctive personality" of Natal, it is necessary to contextualize influences from the rest of South Africa for a further analysis of Natal's emerging colonial identity. Such identities would also express themselves in the form of African agency and conflict, beyond the influences of European expansion during the nineteenth century.

\footnotetext{
${ }^{1}$ Crawford Young, The African Colonial State in Comparative Perspective (New York: Yale University Press, 1994), 44.
} 


\section{The Cape Colony}

The first settlers to arrive in what is today South Africa were not of British origin, but instead the predecessors of the Afrikaner minority which would become the architects of apartheid. Dutch settlers led by Jan van Riebeeck arrived in Southern Africa in 1652 and established a permanent settlement at Cape Town. The Dutch migrants, who initially worked as part of the Dutch United East India Company, turned their attention increasingly to the establishment of pastoral settlements in the Cape hinterland. This was done despite the presence of the Khoikhoi ("Bushman" or "Hottentot" in the colonial literature), who had no tradition of permanent city buildings and whose pastoral lifestyle allowed the Dutch migrants to push further inland. Though slavery was a key component of early settler life and the Dutch settlers built slave lodges in the Cape Town, most laws in this early settler society rested on segregational restriction on slaves owned by the Company being limited to their owner's home. ${ }^{2}$

By 1800 , the Dutch settlers represented the development of a distinct communal identity, what are now known as the Afrikaners or Boer ("farmer" in Dutch), with a distinctive language of Afrikaans, a creole language which incorporated Dutch and other African dialects. These Afrikaners also developed a common cultural identity, centred on their possession of land, a belief in racial superiority, and Calvinist religious tradition. This identity also encouraged a farming and moral system which implied that all Africans were the "children of Ham" and "designed by God to labour as the white man's slaves."3 As a result of this new cultural identity and the dissolving of the Dutch East India Company by the end of the eighteenth century, the Boer population declared two Afrikaner Republics, Graaff Reinet

\footnotetext{
${ }^{2}$ Some strong similarities exist between these early settlements and those in the Americas also set up by the Dutch settlers. See Carl H. Nightingale, Segregation: A Global History of Divided Cities (Chicago: University Of Chicago Press, 2012), 53-54.

${ }^{3}$ Basil Davidson, Africa in History, Revised edition (New York: Touchstone Books, 1995), 267.
} 
and Swellendam, in the land beyond the Great Fish River which had been gradually taken from the Khoikhoi and San groups in the Cape Colony region.

If the European military presence in South Africa began with the establishment of the Dutch East India Company post at Cape Town, it was the Afrikaner or voortrekker (Afrikaans for pioneers, literally “fore-movers") commando system which would dominate military conflicts against the Khoisan, the primary indigenous group of the Cape region. This volunteer settler system of mounted militias counterbalanced the guerrilla warfare favoured by the Khoisan, and would remain a component of Afrikaner military identity into the twentieth century. Beginning in the eighteenth century as a group of employers and volunteers from the Dutch East India Company, by mid-century the commando had become key feature of frontier society. Though Khoisan slaves would initially fight in these units, during the Great Trek the commando system would become a hallmark of the frontier mentality, with no required training or parade drills. By the mid-nineteenth century, the system became more institutionalized, but it still propagated the myth of white self-reliance on the South African frontier. The commando system would also influence to some degree the defensive institutions that were established within the colony of Natal. Yet, the ensuing conflicts in Europe eventually resulted in British maritime power extending its authority over the important global port at Cape Town.

With the loss of the Cape from the Dutch East India Company to the British in 1795, a transition took place within the Cape Colony which would fundamentally alter the Cape for the next century. The authoritarian trade company shifted toward a more franchise-based government of consent which allowed for the increased British population to make considerable headway in reform. This combined with a diversification of culture, population increase, educational improvements, and religious toleration challenged the authority 
established by the Afrikaner population within the Cape Colony. ${ }^{4}$ As the number of British settlers increased, the European population pushed further and further into the hinterland, coming in contact with a greater degree of the African population, and leading to a series of wars with the Khoikhoi and San population. The Cape Mounted Rifles, discussed below, would gain their initial prominence in these conflicts.

An important component of this new frontier society was the emergence of a large "Coloured" population within British rule. The most famous of these groups was the Griqua, who represented a combined population of "Bastaards" (people of European and Khoikhoi slave mixed decent), San, and Sotho and Tswana people. This Coloured population, though more common in the Cape Colony than other parts of South Africa, remained a key racial marker in the evolving makeup and demographics of the region. The fact that the Griqua retained some measure of independence and polity in the frontier region is telling of the social clusters which formed during this period. ${ }^{5}$ It must be noted, however, that the term "Coloured" remained a contentious idea well into the twentieth century. Emancipation in the early nineteenth century gave the Khoikhoi and former slaves the same legal status, so much so they became collectively known as the "Cape Coloured People". Yet so enduring was this terminology that it would remain in use during the apartheid regime, as one of the four main racial categories outlined by the government. ${ }^{6}$

\section{The Great Trek and the British Establishment of Colonial Rule}

Though the Afrikaner population remained an important component of British rule for the first two decades of the nineteenth century, social changes had a dramatic effect on the

\footnotetext{
${ }^{4}$ Monica Wilson and Leonard Monteath Thompson, eds., The Oxford History of South Africa, vol. I: South Africa to 1870 (New York: Oxford University Press, 1969), 272-273.

${ }^{5}$ For more on this social clusters, See Nigel Penn, The Forgotten Frontier: Colonist and Khoe-San on the Cape's Northern Frontier in the Eighteenth Century (Athens, Ohio: Ohio University Press, 2005).

${ }^{6}$ Leonard Thompson, A History of South Africa, 3rd edition (New Haven, CT: Yale University Press, 2001 ), 65.
} 
makeup of the Cape Colony. With the campaign for the abolition of the slave trade and eventually slavery within the Empire and the increase of free labour available, the sources of slave labour were eventually called into question in the Cape, particularly after Parliament's banning of British participation in the slave trade in 1807. Because the Cape Colony never developed a large-scale plantation slave system, free labour became an ever increasing component of the Cape economy. With the removal of formal discrimination against the Khoikhoi and "other free peoples of colour" under Ordinance 50 of 1828 and abolition of slavery within the Empire in 1834, voortrekker animosity toward British rule hardened. ${ }^{7}$

Though the British continued to support the Dutch Reform Church within the Cape region, a policy continued in Natal, Britain began the introduction of its own governmental and legal systems by the early 1830s. In response, between 1834 and 1840 some 15,000 voortrekkers moved from the frontier region of the Eastern Cape to the inland regions removed from British rule. The by-product of this "Great Trek" was the creation of new Afrikaner republics, including the Orange Free State, the South African Republic (or the Transvaal), and the Republic of Natalia, which would later become the British colony of Natal. British interests would follow the Great Trek, however. Within the coming decades, the British would annex the Republic of Natalia in 1844, the Transvaal in 1877, and the entirety of the Afrikaner republics by the conclusion of the Second South African War or Boer War in $1902 .^{8}$

If the Afrikaners threat was somewhat alleviated within the Cape Colony following the Great Trek, the British continued to have difficulties during the early nineteenth century

\footnotetext{
${ }^{7}$ Christopher Saunders and Iain R. Smith, "Southern Africa, 1795-1910," in The Oxford History of the British Empire: Volume III: The Nineteenth Century, ed. Andrew Porter (Oxford: Oxford University Press, 2001), 599.

${ }^{8}$ The annexation of the Transvaal will be an important event in the history of Natal development as well as the personal history of Theophilus Shepstone. Lord Carnarvon, the Secretary of State for the Colonies, instructed Shepstone to negotiate or proclaim British control of the Transvaal in 1877 as part of a confederation scheme. The scheme failed, but the British did retain control of the Transvaal until the end of the First South African War in 1881.
} 
as settlers continued to expand deeper into the African interior. Even with the establishment of British rule in Natal in 1844 (see below), there remained a prominent frontier region adjacent to the Cape Colony and part of the Eastern Frontier region, known as Kaffraria. ${ }^{9}$ This area was dominated by the Xhosa. Ironically, despite the presence of the Zulu in the collective imagination of the British as being the most aggressive and warlike Africans of South Africa, it was the Xhosa who would continue to act as a source of contention and conflict. Nine wars were fought in the Kaffraria between 1779 and 1879 before colonial white dominance was assured in the region. Though the response in Natal to the eighth "Frontier" or "Xhosa War" will be discussed below, the Xhosa people in Kaffraria were representative of the longest spell of resistance in modern South Africa. ${ }^{10}$ It was for the Xhosa that the British had to make a policy of rule, and it was the actions of the likes of Sir Harry Smith that solidified the British blueprint for action against the indigenous African population of South Africa. It was even the Xhosa who were the first Africans a young Theophilus Shepstone, architect of the indigenous policy of Natal, interacted with during his time as an interpreter for the Cape government before his arrival as diplomatic agent in the colony of Natal.

The British conquest and administration of Kaffraria, though tangential to the topic of this dissertation, is telling of the methodologies of British rule during this period, and the eventual factors which inspired colonial rule and state formation in the region. Kaffraria, part of what is today the Eastern Cape Province (known as the Transkei and Ciskei during apartheid), was the provincial frontier of the Cape Colony for the vast portion of the early nineteenth century. The region, though largely occupied by the Xhosa people, was not under

\footnotetext{
${ }^{9}$ This area would also include "British Kaffraria", a British colonial territory that laid between the Fish and Kei Rivers. This colonial territory existed between 1847 and 1865 until it was incorporated into the Cape Colony.

${ }^{10}$ Price rightly points out that "it is rather surprising that the Xhosa remained relatively unknown to the British. Yet Nelson Mandela is a Xhosa, as is Thabo Mbeke; and the ANC is a Xhosa-dominated party." See Richard Price, Making Empire: Colonial Encounters and the Creation of Imperial Rule in Nineteenth-Century Africa (Cambridge University Press, 2008), 2.
} 
any central rule, unlike the Zululand to the north. Instead, like many Nguni societies, the Xhosa were composed of a collection of chiefs who controlled a defined area under a particular chiefdom. In some cases, these chiefdoms were subdivided into smaller chiefdoms, and some grew into sizable communities, such as Chief Hintsa who in 1809 had some 10,000 followers with eleven chiefs under him. ${ }^{11}$ By 1800, the Xhosa were composed of at least two and possibly nine chiefdoms, allowing for the British to take gradual control of the territory piece by piece, creating alliances and conquering those chiefs who did not fall under imperial rule. Systematically, the Xhosa would fall under British rule, either through alliances or direct action.

The infamous Hintsa incident was such an episode of "direct action". It was important not only in the rise to prominence of Sir Harry Smith, the future Governor of the Cape Colony during the early period of Natal, but also in the manner in which British administration of indigenous leaders was managed in South Africa. During the war of 183435, then Cape Governor Benjamin D’Urban (namesake to the city of Durban in Natal) and Colonel Harry Smith demanded that Hintsa, a powerful Xhosa chief who was baselessly suspected of organizing the rebellion against the British, deliver 40,000 head of cattle as coverage to end the war, as it was suspected, again unfounded, that his territory was being used as refuge for the cattle of the chiefs fighting the British. Under the false pretext of negotiation, Hintsa was lured to a camp, captured, and summarily interrogated on the verge of torture. Though eventually agreeing to the British demands, Hintsa was not released and was later killed and his body mutilated in an escape attempt. ${ }^{12}$ As will become clear, such tactics were not unheard of, at least to some degree within the administration of other areas of South Africa, including Natal. What the Hintsa incident anticipates, however, is the manner

\footnotetext{
${ }^{11}$ Wilson and Thompson, The Oxford History of South Africa, 118.

${ }^{12}$ For a further account of the event and the response, see Price, Making Empire, 240-241.
} 
in which British agents attempted to use their authority and sometimes unfounded trust with the indigenous population to manipulate events and allow for greater expansion of colonial rule.

Such tactics were not supported by the Colonial Office, but instead representative of the level of independence which was exhibited by the men on the ground in South Africa. For much of South Africa, including Natal, direct or indirect British guidance superseded any formal British rule where it existed. Instead, administrative responsibility fell onto the local European settlers who acted as local agents who made the vast majority of decisions on the ground. In essence, the British government exercised limited formal responsibilities and allowed the colonies to manage themselves, except in cases of extreme need, with the AngloZulu War being one of the most famous examples. Although this remained part of the major tactics within the Empire, the irony rested on the fact that attempts to bring about greater unity led to increased involvement by the British government into the interior of South Africa by the conclusion of the nineteenth century, the key example being the two Boer Wars. ${ }^{13}$ Such actions within the Empire, however, move beyond the purview of this dissertation. Instead, it is important to contextualize the manner in which the African population in South Africa established itself during the precolonial period, especially at the dawn of the founding of Natal.

\section{Mfecane and Difaqane}

Historically, the Great Trek is illustrative of the founding of Afrikaner nationalist identity. Historiographically, it has become representative of the apartheid historical legacy which dominated early writings of the period. For the purposes of this dissertation, the importance of the Great Trek rests in the resulting interaction between African and Afrikaner

\footnotetext{
${ }^{13}$ Saunders and Smith, "Southern Africa, 1795-1910," 603.
} 
communities as the migrants moved across the eastern part of the continent. Though the motivations for this migration were driven by the interests of land and labour, racial perceptions would pervade the mind-set of the voortrekker. For the Afrikaner, the land they settled, which included Natal, was a land largely devoid of any substantial African population. Though such perceptions were unfounded, Southern Africa had experienced a series of conflicts which scattered or divided many segments of the African population. Punctuating this series of conflicts are two events that have been called the mfecane and the difaqane. Both terms remain contentious historiographic concepts which must be addressed before examining the founding of Natal.

Those who support the mfecane argument believe it was an autonomous event that occurred outside of European influence. J.D. Omer-Cooper's work provided the basis for the mfecane thesis, which became a staple of the historiography of nineteenth century South Africa. ${ }^{14}$ The thesis essentially states the during the early nineteenth century, the Zulu kingdom propagated a "crushing" or "scattering" of Nguni people across Southern Africa which resulted in a period of migrancy and increased state-building throughout the subcontinent. Julian Cobbing and his student John Wright opposed this view, contending that there was an active European force involved in the affairs of South Africans particularly interactions with the Zulu and Sotho. Cobbing rightly placed the history of early nineteenth century Natal outside the scope of pre-colonial history, arguing that pressures from the Portuguese, Afrikaner, and British influenced events within the interior. There remains, however, considerable contention over the role of slavery and labour demands at the centre of Cobbing's research, in which he claims that the missionaries at Dithakong in the North Cape

\footnotetext{
${ }^{14}$ The foundational argument is at the centre of Omer-Cooper's most famous work. See Omer-Cooper, The Zulu Aftermath.
} 
region were "fully and consciously engrossed in what they were doing, i.e. collecting slaves" and that "slaving was having a dramatic impact" on the region. ${ }^{15}$

Such actions also called into the question the connecting thesis of the mfecane, known as the difaqane, meaning "forced migration", which acted as a reference point to wars in the interior of South Africa before the Afrikaner arrivals in the $1830 \mathrm{~s} .{ }^{16}$ In principle, the $m f e c a n e$ took place in the south-eastern section of South Africa impacting Nguni-speaking peoples while the difaqane took place in the region west of the Drakensberg, impacting the Sotho, Tswana, and Pedi areas. The term difaqane gained considerable ground in Wilson and Thompson's Oxford History of South Africa, where it was popularized and became part of the common usage in academia, particularly in South Africa. ${ }^{17}$ It was the prominence of both these ideas within the South African academia which eventually led to the heart of Cobbing's critique of the thesis, and his challenge to historical representation of early nineteenth century South Africa.

Though not completely dismissing Omer-Cooper's work on pre-colonial Africa, Cobbing's main claim rested on the belief that the mfecane thesis was an apartheid myth created by liberal historians to legitimize racial inequality in South Africa. Cobbing and Wright criticized the journals and diaries of Nathanial Isaacs and Henry Francis Fynn, but were not able to provide alternatives in relation to the historical understanding of the emergence of Shaka and the early Zulu kingdom. For Cobbing, the concept of the mfecane as

\footnotetext{
15 Julian Cobbing, "The Mfecane as Alibi: Thoughts on Dithakong and Mbolompo," The Journal of African History 29, no. 3 (1988): 493, 509.

${ }^{16}$ So similar are these terms that historian Omer-Cooper used them practically interchangeably in ZuluAftermath, assuming difaqane was a straight Nguni translation of mfecane.

${ }^{17}$ Wilson and Thompson outline the causes being linked to the expansion of the Zulu kingdom and the mfecane and date the difaqane to between 1822 and 1836. See Wilson and Thompson, The Oxford History of South Africa, 391.
} 
a great upheaval caused by the Zulu was "integral to a white settler, 'Liberal' history." 18 In this sense, Cobbing was referring to settler historians, liberal historians, and apartheid apologists as essentially presenting the same belief that the political revolution in the Zululand was entirely self-contained. In doing so, Cobbing argued that this created a narrative which justified the racially unequal division of the land.$^{19}$ It remains difficult, however, to completely prove the source of these migrations or depopulation patterns in South Africa. Cobbing's work, though fundamentally important to the debate, also retained faults in his own analysis of the historiography. ${ }^{20}$ The current state of this debate is still contentious, with some historians accepting the validity of Omer-Cooper's claim while acknowledging the need for a multifaceted examination of the causes of this massive migration, and others outright dismissing the use of the term as evident by the disruptions caused by Europeans beginning in the nineteenth century. ${ }^{21}$ What remains important is that during the period of initial settlement of Natal, South Africa as a whole had experienced a dramatic movement of people and social groups, leading to a fragmented, and sometimes amorphous indigenous presence which the European settlers, particularly the Afrikaners, used to their advantage. ${ }^{22}$ Whether internal or external, the mfecane and the difaqane fundamentally set the stage of further European expansion and settlement in South Africa.

\footnotetext{
${ }^{18}$ Cobbing, "The Mfecane as Alibi: Thoughts on Dithakong and Mbolompo," 487.

${ }^{19}$ Ibid., 519.

${ }^{20}$ A summary of such discrepancies can be found in Christopher Saunders, "Pre-Cobbing Mfecane Historiography" in Carolyn Hamilton, ed., The Mfecane Aftermath: Reconstructive Debates in Southern African History, 1st ed. (Witwatersrand University Press, 1995), 21-34.

${ }^{21}$ See John Wright, "Political Mythology and the Making of Natal's Mfecane," Canadian Journal of African 23, no. 2 (1989): 272-91; J. D. Omer-Cooper, "Has the Mfecane a Future? A Response to the Cobbing Critique," Journal of Southern African Studies 19, no. 2 (June 1993): 273-94. For a comprehensive examination of the debate, see Hamilton, The Mfecane Aftermath.

22 This debate remains ostensibly about labels and the understanding of those labels. As Dan Wylie argues: "The misleading and politically overcharged labels of 'Afrocentric' and 'Eurocentric' processes or approaches must be abandoned, along with any notion of some clearly defined, geographically and chronologically bound "time of troubles' coincident with Shaka's reign." While a valid argument, labels remain an important tool for our historical understanding of the past, hence the continuing use of these terms. See Wylie, Myth of Iron, 439.
} 
Though this dissertation has used the term mfecane, it has done so sparingly and only in the historiographic context. This is not to dismiss the importance of the mfecane thesis, but instead to lessen its overall impact on this dissertation. The mfecane was an important event in the history of Southern Africa and was likely caused by a combination of both European and African involvement. By illustrating how Natal responded to the aftermath of the mfecane, caused either by European or African actions, this dissertation better contextualizes the mfecane debate, and illustrates the manner in which African and European agency acted in conjunction to create the layout of South Africa during the nineteenth century.

\section{A Short History of Natal}

Having contextualized the wider scope of South African history in which this dissertation is situated, we can now move to the primary locale of this topic: Natal. Located along the eastern frontier of the Cape Colony and below the established Afrikaner Republics of the nineteenth century was the British colony of Natal. It was first named by Portuguese explorers, who gave it the name on Christmas day, 1497 (Natal is the Portuguese word for Christmas). The territory, stretching roughly 150 miles along the Indian Ocean between the Tugela and Umzinyati Rivers in the North, and the Umzimkulu to the South with its western boundary largely defined by the Drakensberg Mountain range, has had both a diverse and complicated history from the first permanent European settlements in the nineteenth century. ${ }^{23}$ Below is a brief and incomplete account of the history of Natal during the nineteenth century. The intention of such a summary is not to dismiss the major nuances of Natal's early history, which will become more apparent in the body of the dissertation, but

\footnotetext{
${ }^{23}$ See Appendix: Map 1 and 2
} 
instead of provide some historical context for the larger events taking place over the scope of this dissertation. ${ }^{24}$

Originally a stopover for Portuguese traders, the region of Natal was generally ignored by European settlers until the nineteenth century. Then, after initial contact with the Zulu King Shaka by British settlers in the 1820 s, the area gained its first semi-permanent European settlers. In 1839, as a by-product of the Great Trek, Afrikaner settlers would establish the Republic of Natalia. The voortrekkers had crossed the Drakensberg Mountains in 1837, and had defeated the Zulu kingdom under Dingane (brother and successor to Shaka), on December 15, 1838 at the notorious Battle of "Blood River" on the River Ncome. Whereas the battle was decisive in preventing the Zulu from overtaking this European settlement, it left a number of questions related to the policy of African administration unanswered. Such questions remained in 1841, when the British announced their intentions of annexing Natal. Though Britain had staked an initial claim to the area around Port Natal during the 1820s with the expedition to contact the Zulu King Shaka led by Captain James King and Henry Fynn (who, incidentally, also provided the main travel narratives on which the contentious source for much of the mfecane thesis is derived), the Afrikaner migration to the region in the 1830 s limited British interaction in the region to little more than simple trade relations in the territory. However, the presence of the Afrikaner republic along Britain's sea route to India was perceived by the British in the Cape as a threat, especially once the republic began encroaching on the eastern frontier of the Cape. By 1842, Port Natal, later renamed Durban, had been seized as a British interest and the Cape government had begun to make designs on the territory, recognizing the opportunity for greater trade security by possessing the strategically important Port of Natal. After brief confrontations between the

\footnotetext{
${ }^{24}$ For a more comprehensive examination of the region and a fitting starting place for any detailed research on this period, see Duminy and Guest, Natal and Zululand from Earliest Times to 1910.
} 
British colonial military and Afrikaner commandos, the administration of the Cape Colony declared the district of Natal British territory in May of 1844.

Under the direction of the Cape Colony governor, Natal was instructed to form its own colonial government and executive council, with the Lieutenant-Governor of Natal Martin West reporting to the Governor of the Cape Colony. The colony of Natal, despite its political connections to the Cape, retained a sizable level of autonomy in light of Natal's somewhat remove location beyond both the Cape Colony and British Kaffraria. Through this relatively autonomous administrative arrangement, Natal would continue to experience steady growth throughout the formative period of the colony, though the settler population would always remain modest in size. In 1852, the European population was only 7,629 while the African population exceeded 100,000. By 1880, European or "whites" had increased to 25,271 as the African population continued to grow at over $362,000 .{ }^{25}$ Pietermaritzburg, the colonial capital, was one of two prominent urban areas during this period. Pietermaritzburg increased from a population of 300 houses and two thousand people in 1854, to 701 houses and 4,491 people by 1863 , to well over 10,000 people in $1881 .{ }^{26}$ Durban, the major port of the colony, also saw significant expansion, with a population of 1,204 Europeans in 1854, 8,241 by 1874 , and 67,847 by $1904 .^{27}$

Like much of the rest South Africa, the indigenous African population remained one of the key components of concern for much of this early formative period. The primary solution to the "native question", as it was referred to, came in the form of the locations system. The locations system, adopted by Theophilus Shepstone, Diplomatic Agent to the

\footnotetext{
${ }^{25}$ An Indian population of 18,877 meant the colonial population of Natal in 1880 was 404,363 versus 120,627 in 1852 (the first year accurate numbers were compiled in the colony). "Population”, Natal Blue Books, 1852, 1880.

${ }^{26}$ Ingram, The Colony of Natal, 187.

${ }^{27}$ W. P. M. Henderson, Durban: Fifty Years' Municipal History (Durban, South Africa: Robinson, 1904), 3, 53, 122.
} 
Native Population, and the Commission for Locating the Natives in 1847, was created with the intention of directing and controlling the massive indigenous population that had become a growing concern in the colony, especially in regards to the disparity in numbers between the European and African population. The system envisioned the creation of a number of individual African communities within the colony of Natal, largely within massive "native reserves" which was administered and overseen by a government magistrate, who acted partially as administrator of justice and partially as tax collector. Within this system, indigenous authorities, namely the African chiefs, were permitted considerable autonomy and authority within their own group. Final authority rested with the lieutenant-governor, who was given the title of "Supreme Chief". The intent of Shepstone's ideal policy, which he advocated from 1846 to 1852 , was the gradual process of "civilizing" the indigenous population though preserving indigenous traditions while allowing for "tenets of civilization" to be incorporated into African society.

Shepstone's system was specifically characterized by his personal relationship with the indigenous population. Shepstone's ability to interact with and direct the indigenous population would be one of the key factors in the long term survival of the locations system. For much of the early period of Shepstone's administration, he remained one of the few government officials to physically interact with the Africans. It should be noted, however, that Shepstone's system of colonial administration has been attributed to the beginnings of "indirect rule" by the likes of Mahmood Mamdani and his work Citizen and Subject. Though Mamdani places Shepstone and Natal at the forefront of the emergence of indirect rule, he admits that the system emerged through "trial and error" and it "was a good half-century before it could be codified as law in Natal". ${ }^{28}$ It is this trial and error period which made

\footnotetext{
${ }^{28}$ Mahmood Mamdani, Citizen and Subject: Contemporary Africa and the Legacy of Late Colonialism (Princeton, N.J: Princeton University Press, 1996), 62.
} 
Shepstone the ideal candidate for the development of Natal's indigenous policy. It should be noted, however, that although Mamdani's work as become the baseline for many Africanists' understanding of the placement of Shepstone and Natal in the development of indirect rule in Africa, it has been challenged by scholars such as Jeff Guy, who argue that this approach could be the result of a misreading of the sources as "the admirable sweep of Mamdani's approach has exposed gaps and omissions in his argument, and certainly his treatment of the policies attributed to Shepstone in Natal is misleading". ${ }^{29}$

Despite this debate, there was no question that Shepstone was well suited to the task of diplomatic agent, largely due to not only his experience in the Cape frontier, but also his mastery of multiple African languages (though admittedly there are striking similarities between Xhosa and Zulu). As diplomatic agent and later secretary for native affairs in Natal, it would become Shepstone's job to not only deal with indigenous concerns, but, on several occasions, to act as the representative to the British crown. This type of interaction would eventually result in the association of Shepstone as the true symbol of power to the indigenous populations in Natal. It should be noted, however, that Shepstone was typically the sole translator of British policy, allowing him to keep both British and indigenous interpretation of his policies separate and controlled. ${ }^{30}$ Such power and control will be evident in his management of the indigenous population illustrated below. By 1851, there were seven locations, each with an average size of 180,000 acres and largely under the jurisdiction of Shepstone. The locations system would be a major source of debate within the colony, especially after the death of the first Lieutenant-Governor Martin West and the arrival

\footnotetext{
${ }^{29}$ Guy points particularly to the interpretation of the Natal Locations Commission of 1847 , and the perceived assertion that African authority did not exist in 1846-47. Admittedly, Guy attributed such confusions to a lack of consistency in Shepstone's own writings. See Guy, Theophilus Shepstone and the Forging of Natal, 10.

${ }^{30}$ Jeff Guy, "An Accommodation of Patriarchs: Theophilus Shepstone and the Foundations of the System of Native Administration in Natal," Colloquium: Masculinities in Southern Africa, University of Natal, Durban (24 July 1997): 6. This same concept is examined more deeply in Guy's recent book on Shepstone. See Guy, Theophilus Shepstone and the Forging of Natal.
} 
of Benjamin Pine. Pine believed the best means for civilization rested on the complete removal of the African from his indigenous traditions, which represented a complete break with the past British policies. Such beliefs, however, did not limit Pine's attempts to use such indigenous traditions for military purposes, as will be discussed below.

Pine's intentions for the Africans were more in line with the opinions put forward by Earl Grey, Secretary of State for War and the Colonies. He believed that because the Africans were so spread out and "half of this population was made up of remnants of clans without chiefs", that Natal would be the perfect environment to organize these groups into more concentrated, smaller communities that could be more easily governed. Pine almost laments at the lost opportunities within the district to "mould [Africans] more easily to our views" and the removal of some indigenous practices, such as witchcraft, that "stood most in the way of their civilization, [which] might have been imposed as the indispensable terms upon which permission to inhabit the district should be granted to them."31 Pine perceived the indigenous situation in Natal to have been no better than any other indigenous tribe outside of British influence. Pine was not only fearful of the indigenous culture and tribal customs, including the concept of multiple wives for each African male, but was also concerned as to what effect this situation would have on the British settler. Pine wrote, "How can an Englishman with one pair of hands compete with a native man with five to twenty slave wives?"32 Interestingly, such a viewpoint links directly to the idea of controlling women's reproductive power, which can be seen as a key to controlling labour resources. The lieutenant-governor's concern not only rested with the placement of the Africans, but on how they would affect the economy of Natal a whole.

\footnotetext{
${ }^{31}$ British Parliamentary Papers (BPP): Natal. Further Correspondence Related to the Settlement of Natal (In continuation of Papers presented July 30, 1851), No. 9 Extract of a Despatch from Lieut.-Governor Pine to the Governor-General, dated Government House, Natal, November 1, 1851.

32 Ibid.
} 
Pine was not the only English official concerned with the principles of labour within the colony. Reverend William C. Holden, a long-time resident of the colony and part of one of the first Wesleyan missions in Natal, published a pamphlet in 1850 entitled "The Kafir Labour Question." ${ }^{33}$ Holden points out in his pamphlet that considerable strain was felt by the European farmers of Natal largely because of a lack of accessible indigenous labour within the colony. The pamphlet not only includes several possible solutions to the problem which were echoed within the European community, but also gives a solid understanding of the colonists' view of the Africans and their place within colonial society.

Holden's stance on the indigenous problem within Natal was very similar to that of Pine. Holden believed that the locations system itself was flawed and that the plan was "false in its principles, and injurious in its consequences." The idea of keeping the Africans as a "separate, distinct people, enjoying their own heathen rights and immunities" was seen as a great injustice by Holden. Like Pine, Holden believed that on the arrival of the British, the Natal Africans were in an ideal position to be influenced as they were "scattered, broken, powerless, and honest, and this disposed [the Africans] to submit to any form of government under which the English might be pleased to place them". ${ }^{34}$ But instead, the Africans were allowed to remain within their tribal societies, which Holden points out were "grossly impure" and "contrary to the dictates of humanity." 35 Within such a view, Shepstone's locations were presented as an invented chiefdom system, and, though largely untrue, individuals such as Pine and Holden saw a lost opportunity to "civilize" a malleable African population that had been placed in a system that had yet to be entrenched. The opportunities to create a truly "civilizing mission" for the African population would not be achieved.

\footnotetext{
${ }^{33}$ This pamphlet was included within Holden's History of the Colony of Natal in Chapter VIII, "The English Government of the Natives." See William C. Holden, History of the Colony of Natal, South Africa. (London: Alexander Heylin, 1855), 177.

${ }^{34}$ Ibid., 179.

${ }^{35}$ Ibid., 179.
} 
Despite these criticisms, Shepstone outlasted his critics and was able to place the locations under secure legal standing with the Natal Native Trust in 1864, thus preserving the system for the remainder of the formative period. The colony was never, however, able to fully fund the system, as administrators, magistrates, and proper oversight was never readily available. Natal experienced what many British colonies suffered during the early expansion of the Empire: what John Galbraith described as "humanitarianism on the cheap." ${ }^{36}$ Despite the locations system becoming the established norm within the colony, it remained representative of a limited commitment to the major problem of the ever increasing African population within the colonial structure, a problem which would permeate itself in the colony's defensive structures as well.

By 1856, Natal was granted a Colonial Charter and became an independent colony, with its own representative institutions and fully independent administrative structures, in the form of legislative and executive councils. It was at this time that both the boroughs of Pietermaritzburg and Durban attained their own status as corporations and began the process of creating their own town councils and administrative systems. Though there were a number of economic and internal struggles which permeated this formative period, the colony was able to maintain relative peace and security. The threat of a Zulu invasion was a consistent refrain, as will be shown, but there was little open conflict between Natal and its neighbours to the north. That did not mean that Natal did not influence or interact with the Zulu nation, but it did avoid direct conflict. This was evident in Shepstone's trip to the coronation of King Cetshwayo in 1873, which involved a physical crowning process and a proclamation by Shepstone of "coronation laws" which, if at the time had no particular sway over the Zulu, was later used as a pretext for the invasion of the Zululand in 1879. Though maintaining

\footnotetext{
36 John S. Galbraith, Reluctant Empire: British Policy in the South African Frontier, 1834-1854 (Westport, CT: Greenwood Press, 1978), 279.
} 
some semblance of peace and security (as will be somewhat called into question in the greater part of this dissertation), there remained multiple avenues and opportunities for debate, conflict, and even violence within Natal during this formative period.

Though this dissertation ends with the Anglo-Zulu War of 1879, the repercussions of the conflict on the history of Natal do not end there. Debates would continue to rage over the matters of land, labour, and most importantly, security. The threat of Zulu power in South Africa would be diminished by the defeat of the Zulu Kingdom in the Anglo-Zulu War of 1879 , though the threat of a Zulu uprising was present until the Bambatha Rebellion of 1906. ${ }^{37}$ The principle causes of the rebellion, however, stemmed more from the imposition of a "Poll Tax" rather than an overriding revolt against British authority. With the defeat of the Zulu in 1879, British attention in Natal would shift for the remainder of the nineteenth century to the Afrikaner population in the Transvaal and Orange Free State. Such tension would eventually result in the two Boer Wars and would help solidify the formation of an Afrikaner nationalist identity which would define the social and military tradition of the white community of South Africa in the coming century.

However, the story does not end so quickly. After the complete dissolving of the Zulu kingdom in the $1880 \mathrm{~s}$, Natal began to focus more intently on attaining greater prosperity. ${ }^{38}$ Though an attempt at confederation with the Transvaal and Cape Colony was made in 1875 by Lord Carnarvon, it was deemed a failure after the inability of the British to hold onto the Transvaal following its annexation in 1877. Natal, however, would eventually achieve responsible government, along the lines of other segments of the dominion, in 1893. Two decades later, Natal voted 11,121 to 3,701 to be incorporated into the Union of South Africa

\footnotetext{
${ }^{37}$ For a detailed account of the rebellion, See Marks, Reluctant Rebellion; Jeff Guy, Remembering the Rebellion: The Zulu Uprising of 1906 (Scottsville, South Africa: University of KwaZulu-Natal Press, 2006).

${ }^{38}$ For more on the civil war that eventually finished any hope of a renewed Zululand, see Guy, The Destruction of the Zulu Kingdom.
} 
in May 1910.With the exception of the Anglo-Zulu War and the Boer Wars, Natal had retained, for most of its history, a level of security which was nearly unprecedented in the region during this period. How and in what ways was this security achieved are questions that lie at the heart of this dissertation.

This chapter has attempted to contextualize the formation of Natal within the borader landscape of an emerging South Africa in the nineteenth century. Its intent is to provide the important background necessary for developing a deeper understanding of the importance of Natal's place in South African history. Concerns related to the African population and conflict with the Afrikaners will remain strong subtexts for the remainder of this dissertation, and should illustrate that the formation of Natal as a colonial state was wrought with problems, debates, and overwhelming concerns, not only for security, but for racial and economic issues. These defensive institutions, the examination of which make up the heart of this dissertation, were only one such entity in the "web of structures" which were established during this formative period. Through the case studies examined below, their importance will become even more apparent in understanding the making of Natal. 


\section{Chapter Three: Volunteers}

\section{Introduction}

During the Cape Frontier War of 1851, there was a general fear amongst the colonists of Natal of an indigenous uprising that would threaten the lives of European colonists. ${ }^{1}$ In response, solutions for the defence of the colony were formulated, including the raising of indigenous levies from the African population. Thomas Phipson, future sheriff of the colony, was one of the more outspoken critics of the rumoured policy of raising indigenous levies. At this time, most African military units within Natal were used to a limited extent in internal matters. Phipson argued that the creation of formal indigenous units was not only immoral, but illegal because such actions lacked approval by the colonial population and were implemented solely on the authority of Lieutenant-Governor Benjamin Pine. Phipson's suggestion was to rely on white volunteers from within the colony for defence, stating that "a volunteer is worth two pressed men."2

If the formation of Natal as a colonial state was invariably linked to the establishment of the colony's defensive institutions, then it is important to begin the analysis with the institution composed primarily of those who formed the colonial government: the European volunteer corps. One of the most visible pillars of the Natal's colonial defence, the volunteer corps represented an attempt by the European members of the colonial community to address the problems of colonial rule and security. Acting as a continuation of the military traditions and systems that were gaining popularity in Europe, volunteering became a means through which the citizens of Natal were able to take part in the protection of the colony while

\footnotetext{
${ }^{1}$ The Cape Frontier War, also known as the Xhosa War, was one of the multiple conflicts that took place within British Kaffraria during the mid-nineteenth century. Briefly discussed in the previous chapter, more details about this conflict will be discussed later in Chapter Six: African Military Units.

${ }^{2}$ Currey's criticism will be revisited later in Chapter Six: African Military Units. See R.N. Currey, Letters and Other Writings of a Natal Sheriff: Thomas Phipson, 1815-1876 (Cape Town: Oxford University Press, 1968), 32.
} 
remaining viable members of the colonial community outside of military responsibilities. Because of their consistent and sizable place within the white colonial community, the volunteers became the idealized form of everyman's contribution to the protection of the colonial state.

The volunteers, more importantly, were not simply the members of Natal's defensive forces, but were also important figures in the development of Natal as a colonial state. Lieutenant-governors, police commanders, magistrates, clerks, businessmen, and administrators all made up the ranks of the volunteer corps. Therefore, by examining the development and evolution of the volunteers, it becomes easier to trace the development of the colony of Natal as a whole. This also reveals their major importance to the emergence of Natal's security cognizance. The defence and security of the colonial state, in the eyes of many within Natal, rested on the "brave men" of the volunteer corps. The practicality of this assumption, though largely unfounded, still resulted in the volunteer corps holding an important place within the colonial consciousness and the emerging notions of what defined Natal during its formative period.

This chapter will move through the formative period of the colony of Natal, examining the formation and organization of the volunteer corps within the colony and provide key examples of their role in Natal's colonial defence. By more intensely considering the problems, limitations, and perceptions of the volunteers, the important place of the volunteer within Natal's defensive structures will be realized. Matters of equipment, readiness, and discipline will all be addressed, with particular emphasis on the lack of preparation which characterized the volunteer system for most of Natal's formative period. Though the most visible element of Natal's defence, at least amongst the European community, the lack of success from the volunteers will illuminate their overinflated place 
within Natal's history, and challenge the established settler narratives which permeated the early historiography of the colony. The complexities of the volunteer system's place within Natal will instead illustrate the fluid nature of defence within the colony and the solutions to colonial safety during the colony's formative period.

In 1854 , the lieutenant-governor of Natal approved the volunteer law which formalized the organizational structures of the volunteer units of the colony. It was the first such law in South Africa. At the time there were five units ranging between 30 and 100 troops within the colony of Natal. By the end of 1878 with the build-up to the Anglo-Zulu War, the colony possessed 15 units numbering 760 men. Nevertheless, the impact of these volunteer military organizations on the security and organization of the British colony of Natal during the mid-nineteenth century went beyond a mere military build-up. The military systems within Natal, particularly the volunteer corps, were part of a more general militarization of Natal society which continued throughout the formative period of the colony, from the founding of the colony in 1845 to the Anglo-Zulu War of 1879. Government regulations between the enactment of the Volunteer Law of 1854 and the Volunteer Regulation Act of 1877 illustrate the evolving nature of defence within the colonial state, as well as legitimate concerns for the issue of security, especially in response to the continuing influx of an indigenous population that estimates placed around 100,000 by $1845 .^{3}$ The European population would make use of the volunteer system as not only a means of collective security, but as an instrument of power within the colonial state. Yet the formation, preservation, and continuation of these volunteer systems would be consistently challenged, dismissed, and even abolished by members of the colonial government, the press, and citizens

\footnotetext{
${ }^{3}$ Though an official census of the African population was not taken until the $1850 \mathrm{~s}$, with the Natal Blue Books indicating a "coloured" population of 112,988, the Commission for the Locating of the Natives reported to Lieutenant-Governor West in 1847 that the African population was "estimated with perhaps greater accuracy at 100,000." BPP: Correspondence Related to the Establishment of the Settlement of Natal, Enclosure in No. 65: Martin West to the Governor of the Cape of Good Hope, April 22, 1847.
} 
of the colony who had alternative plans and suggestions of how the colony should defend itself. Despite the presence of a strong military detachment of the $45^{\text {th }}$ Infantry Regiment at Fort Napier, the European colonists still believed in the necessity of maintaining their own elements of security within the colony, even when those systems were impractical, ineffective, or even criminal. Ironically, despite the shortcomings of many components of this system, the volunteer corps would remain one of the most enduring and praised aspects of Natal's security institutions for much of the formative period of Natal.

It should be emphasized that this chapter is not meant to be a "white man's history of Africa" but instead attempts to demonstrate the place of white European settlers within the defensive structures of the colony of Natal. By illustrating the clear agency exhibited by white settlers outside of the official British military, the apprehensions and source of tension with the indigenous African population will become clearer. By understanding how the colonists defined themselves, greater links between English and European identity and overall perceptions of defence materialize. What the volunteer systems illuminated was the means through which the European population of the colony of Natal coped with the concerns for security, but also their attempts to address their own place in the emerging state. The fear of invasion, the formalization of the volunteer system, the solutions to discipline, and the response of the volunteers during crises like the Langalibalele Incident and the Anglo-Zulu War all address the critical question of the place of the European within Natal's defensive institutions. By providing such an encompassing view of the volunteers during the formative period of Natal, their relationship with the other pillars of defence within Natal will reveal the interconnecting concerns from all individuals living within the colony. Despite these overwhelming concerns for security, the expansion of these volunteer military institutions was indicative of a developing state attempting to come to grips with problems of security, stability, and safety during the mid-nineteenth century. 


\section{Volunteering and Natal}

The catalyst for the European styled volunteer system formed in Natal in the midnineteenth century can be traced back to the establishment of British identity during the eighteenth and early nineteenth century, especially during the Napoleonic Wars. ${ }^{4}$ The motivations to volunteer on the British home front during the early nineteenth century were similar to those same motivations decades later in Natal; a mix of patriotism, economic factors, and self-interest. Many settlers were mostly recent arrivals from Britain so they brought these institutional ideas with them from Europe. Though lacking a unified ruling class in Natal, the similarities between Britain of the Napoleonic period and Natal of the midnineteenth cannot be ignored. Britain and Natal both had a proximity to a hostile force, though both threats could be defined in different ways between that of the Zulu Kingdom and the French across the English Channel. Each established new laws to regulate and arm groups of men. Both created in these forces a direct correlation between loyalty to the state and loyalty to the locality of their homes, and along those lines, volunteer corps were local and not national organizations "recruited from a very small area and officered by amateurs from the same neighborhood." Ironically, in both cases the usefulness of these volunteer forces were inflated by a self-engrossing narrative, though it remains possible that the volunteers, as argued by Austin Gee in his analysis of the volunteer movement of the Napoleonic period, played a role in maintaining the state through "gaining the active involvement of civilians and strengthening ties of social allegiance." ${ }^{6}$ The trend that began at the turn of the nineteenth century would continue well through the next five decades till the founding of Natal as a British colony.

\footnotetext{
${ }^{4}$ The number of armed volunteers in Britain in 1803 was around 200,000. Of course, these numbers far exceed any organizations that will be discussed in this paper. See, Linda Colley, Britons: Forging the Nation, 17071837 (New Haven: Yale University Press, 1992), 309.

${ }^{5}$ Though the military experience of the officers and soldiers in Natal could arguably have been more diverse than the groups examined by Colley. Ibid., 313.

${ }^{6}$ Austin Gee, The British Volunteer Movement 1794-1814 (Oxford: Oxford University Press, 2003), 268.
} 
Though a volunteer tradition can be traced back to the Napoleonic period, fundamental question remains of who were these volunteers and what defined them as volunteers. Though there is not a strong delineation between the "volunteer" and the "militia", some distinctions must be made. Though the militia system had consistently existed within the British Empire, the very notion of a "volunteer" was a relatively new concept in the nineteenth century, though it quickly became a powerful symbol of the complete identification of the individual with the nation. ${ }^{7}$ A volunteer was one who willingly served as a defender of one's state or nation, though retained a strong connection to his civilian life. What made the volunteers a distinct entity from a militia was the formal organization that existed within the volunteer system. Officers and men within the volunteers saw themselves as part of a refined military force that moved beyond a simple mustering of armed men, and instead acted within the structures of British military decorum. Though such systems saw an increase in membership in the British home front during the second half of the nineteenth century, it remained an understated component of the British military order. This is even more surprising considering Hugh Cunningham's assertion that as many as one in twelve British men served in a volunteer corps during their lifetime during the late nineteenth and early twentieth century. ${ }^{8}$

The history of the volunteer and understanding their place within the European modelled military systems has only recently come into focus. As with much of military history, the First World War has become the staging point for new research over the last three decades on volunteer service, and understanding the motivations of those involved. ${ }^{9}$ There

\footnotetext{
${ }^{7}$ Christine G Krüger and Sonja Levsen, eds., War Volunteering in Modern Times: From the French Revolution to the Second World War (Houndmills, Basingstoke, Hampshire; New York, NY: Palgrave Macmillan, 2011 ), 2.

${ }^{8}$ Hugh Cunningham, The Volunteer Force: A Social and Political History, 1859-1908 (London: Croom Helm, 1975), 49-50.

${ }^{9}$ For examples of the continuing debate on "war fever" and the role of volunteers, See Jeffrey Verhey, The Spirit of 1914: Militarism, Myth and Mobilization in Germany (Cambridge; New York: Cambridge University
} 
remains, however, little research examining the volunteer elements within colonial organizations outside of Europe, especially in the nineteenth century. The role of the volunteer within the British Empire has not been completely neglected, yet research has focused largely on the regimental history or volunteer activity during times of war, with the South African War gaining considerable attention in the period of imperial expansion. ${ }^{10}$ Nevertheless, little focus has been played to volunteer organizations during peace time, especially in the colony of Natal. ${ }^{11}$ Natal, with its location on the periphery of the British Empire, acts as a clear starting point in developing a better understanding of how volunteer organizations were formed and operated during the rise of the British Empire.

Volunteer corps within the British world was nothing new in 1854. Local militias had been one of the key components of defence within the Empire for much of the nineteenth century. Though the conscript military system had its origins in the French Revolution's Levee En Mass, Britain, "engaged in the imperial hinter-land", possessed an army which "remained quite literally a frontier variant of both the popular-conscript and the mass-reserve styles until the First World War". ${ }^{12}$ It was the home front which acted as the main inspiration for the volunteer movement. The British Volunteer Force, founded in 1859 as a response to the Crimean War, likely acted as the main inspiration for similar volunteer forces within the Empire, including Natal. Originally founded as an invasion defence force of middle class

Press, 2000); Gail Braybon, ed., Evidence, History, and the Great War: Historians and the Impact of 1914-18 (New York: Berghahn Books, 2003), 67-85.

${ }^{10}$ See Claus Nordbruch, The European volunteers in the Anglo-Boer War 1899-1902 (Pretoria: Auslieferung durch Tiegerpoort Versamelaars, 1999); Stephen M Miller, Volunteers on the Veld: Britain's Citizen-Soldiers and the South African War, 1899-1902 (Norman: University of Oklahoma Press, 2007); Jonathan Schneer, London 1900: The Imperial Metropolis (New Haven: Yale University Press, 1999). Schneer uses the volunteer system within London as backdrop to understanding London's place as an imperial metropole. Nordbruch and Miller provide two perspective on European volunteers fighting for either side in the conflict.

${ }^{11}$ An exception is the recently published collection edited by Ian Beckett that provides deeper insight into the role of citizen soldiers during the Victorian period, including analyses on the Dominions, India, Ireland, Britain, and South Africa. See Ian F. W. Beckett, ed., Citizen Soldiers and the British Empire, 1837-1902 (London: Pickering \& Chatto, 2012).

${ }^{12}$ This does not, however, minimize the impact of the British Army within its Empire, but this moves beyond the scope of this dissertation. John A. Lynn, "The Evolution of Army Style in the Modern West, 800-2000," The International History Review 18, no. 3 (August 1, 1996): 531. 
riflemen, the force eventually degraded into a working class military club, though the middle class members would remain officers after initial interest declined. Only being called upon to fall under military law during the time of an invasion, unit cohesion rested almost exclusively on the social interaction between officers and troops, similar to their counterparts in Natal, as will be shown later. Again, more than simply a militia, the volunteers of this era represented a bridge between the Victorian military and Victorian society during the latter half of the nineteenth century. ${ }^{13}$

Segments of the Empire, especially Canada, relied heavily on volunteer systems to maintain local defensive structures. The volunteer movements of North America act as a solid comparative analysis for the volunteer movements of the mid-19th century, especially in the settler colonies of the Empire, such as Australia, Southern Africa, and Canada. For much of the nineteenth century, the Canadian volunteer corps “represented the province's principal contribution to its own defence, providing the mechanism by which a pool of trained manpower would be available in an emergency. For much of this period, British troops guarded the territory against attack and bore the main burden of defence responsibility. Nevertheless, during the numerous emergencies faced by the province in the colonial period the militia played a key role." ${ }^{14}$ Like much of the rest of the Empire, however, Canada would define its ideas of citizen soldiers much later during the build-up to the Great War. ${ }^{15}$ Canada, with its proximity to a possible enemy in the United States, acts as a strong parallel with Natal and the neighbouring Zulu kingdom (though the threat level for both colonies was

\footnotetext{
${ }^{13}$ For a detailed account of this force, see Cunningham, The Volunteer Force.

${ }^{14}$ For a comparative case study of volunteer systems within the British Empire, see the study of the New Brunswick militia, See: David Facey-Crowther, "Militiamen and Volunteers: The New Brunswick Militia 17871871," Acadiensis 20, no. 1 (October 1, 1990): 172.

${ }^{15}$ For a the development of Canadian Citizen Soldiers during this period, see James Wood, Militia Myths: Ideas of the Canadian Citizen Soldier, 1896-1921 (Vancouver: University of Washington Press, 2010).
} 
relatively minimal for much of their existence and fear of invasion was driven almost exclusively by sensationalism). ${ }^{16}$

The concept of volunteer service becomes even more complicated when dealing with a colonial state, as those who served within the colonial system were attempting to strike a balance between systems at home and those within the colony, with all of the local conditions therein. Nonetheless, the manner in which volunteers became a modern phenomenon in the nineteenth century has clear relevance to the formation of colonial defensive structures in Natal. What made the volunteers distinct was their separation from mercenaries, conscripts, or professional soldiers, developing what Krüger and Levsen have called unique "normative judgments." ${ }^{\prime 17}$ As volunteering became more common within the military elements of British society in the nineteenth century, it gained greater positive definitions. Though Krüger and Levsen analysis of volunteering falls under the scope of a traditional European style military, and not in the context of colonial periphery, it still reveals considerable discernments in the relationship between military traditions, the concept of home, and the impact on society in colonial history. These individuals who were part of the volunteer forces illustrate a unique perspective on the use of force, the role of the government in colonial society, and the perception of groups and peoples outside the volunteer system (whether defined by race, gender, or economic status). Through these volunteers, the social, political, racial, and economic structures of colonial Natal this formative period of the colony's history are revealed. ${ }^{18}$

\footnotetext{
${ }^{16}$ Though some accounts, just like Natal, were overblown and reflective of a greater concern for internal security. One such example includes Fenians Raid of 1866, which involved a group of ex-Union Troops staging a raid along the Canadian border. See Hereward Senior, The Last Invasion of Canada: The Fenian Raids, 18661870 (Toronto: Dundurn, 1991).

${ }^{17}$ Krüger and Levsen, War Volunteering in Modern Times, 9-10.

18 The parameters and goals arguably are universally similar for most European style institutions of the nineteenth century. Ibid., 17.
} 
Despite the importance of these systems, previous work on military organizations and their impact on the colony of Natal has largely neglected the topics of collective security and these defensive structures' overall influence on colonial policy and the administration of the colony. One of the few exceptions is Graham Andrew Dominy's PhD dissertation on the garrison at Fort Napier, covering over fifty years of Natal's history and providing a near complete analysis of one of this dissertations neglected defensive structures: the British Army. ${ }^{19}$ Focusing on the British imperial forces of the colony exclusively, Dominy's analysis of the impact of pageantry and its relationship to colonial security as well as the role of "panics" within the colony provides a key component to understanding the importance of the military presence in Natal. ${ }^{20}$ The contributions made by the British Army, however, remains limited regarding their overall impression on Natal as an emerging colonial state, as those within the military hardly made long term contributions to the changing landscape of the colony. The volunteer military corps are also largely ignored in Dominy's work, possibly due to their size or simply because, as we will see below, they were not seen by the military as an intricate component of colonial defence.

Other works on the defensive structures of the colony of Natal largely present the colony as a staging area for other conflicts, including the Frontier Wars of the 1850s and the Anglo-Zulu War of $1879 .{ }^{21}$ Any work done specifically on Natal has been largely relegated to either the Anglo-Zulu War, or later involvement of South African forces in the Boer Wars

\footnotetext{
${ }^{19}$ Graham Andrew Dominy, “The Imperial Garrison in Natal with Special Reference to Fort Napier 1843-1914: Its Social, Cultural and Economic Impact" (PhD Dissertation, University of London, 1995).

20 "Panic" of this form, which is a common theme of this dissertation, is not uncommon to the British Empire. Bayly has particularly examined the impact of spies and misinformation in the creation of public panic in British India. More importantly Bayly creates strong links between the knowledge "panics" and its influence on colonial control and security. See Christopher Alan Bayly, Empire and Information: Intelligence Gathering and Social Communication in India, 1780-1870 (Cambridge University Press, 2000), 96.

${ }^{21}$ Two of the best examples of these works are Stapleton and Thompson, though neither provided considerable focus to Natal during this formative period. See Timothy Joseph Stapleton, A Military History of South Africa : From the Dutch-Khoi Wars to the End of Apartheid (Santa Barbara, Calif.: Praeger, 2010); P. S Thompson, Black Soldiers of the Queen: The Natal Native Contingent in the Anglo-Zulu War (Tuscaloosa: University of Alabama Press, 2006).
} 
or World War I and II. ${ }^{22}$ Those authors that do examine Natal in the nineteenth century do little beyond writing regimental histories or in some cases chronicles of European/white heroism and exploits in Africa. ${ }^{23}$ Two exceptions are Timothy Stapleton's work on colonial South Africa, which provides one of the few starting points in understanding the volunteer system of colonial Natal. ${ }^{24}$ Volunteering is also a component of Robert Morrell's work on colonial settler masculinity, but again the focus on this work centres on the post Anglo-Zulu War era. ${ }^{25}$ In light of this gap in the literature, this chapter will incorporate the more nuanced elements of recent military history to better evaluate the importance of the volunteer corps in the establishment of Natal and the development of an identity amongst the European settlers. In the words of Richard Price, the volunteer systems were an important element in the creation of a "culture of imperial rule in Southern Africa" and more importantly, "what happened to British culture in the empire" during the nineteenth century. ${ }^{26}$

\section{Early Volunteer Corps}

The volunteer corps at the dawn of the colony of Natal was nearly non-existent.

Though there were informal volunteer organizations that had existed in Port Natal before the British annexation of Natal in 1843, including the Port Natal Volunteers, this early corps consisted of little more than 20 Europeans (with 16 of the total corps being officers) commanding groups of local Africans. The Port Natal Volunteers were little more than a local militia, and did not have the formal military organization of later volunteer corps. It was

\footnotetext{
22 Alan Frederick Hattersley, Carbineer; the History of the Royal Natal Carbineers (Aldershot,: Gale and Polden, 1950). Though useful, many of these sources do not move beyond the simple facts and figures of the corps or evaluate their overall importance on the colony of Natal.

${ }^{23}$ Even Morris' work on the Zululand, though one of the most widely read books on the formative period, only makes passing reference to the volunteers and their involvement in set pieces during the 1850s, 60s, and 70s: See Morris, The Washing of the Spears.

${ }^{24}$ Stapleton rightly links the development of the commando system with the volunteers as a foundation for latter military development after the South African War. See. Timothy Stapleton, "South Africa" in Beckett, Citizen Soldiers and the British Empire, 1837-1902, 139-170.

${ }^{25}$ Robert Morrell, From Boys to Gentlemen: Settler Masculinity in Colonial Natal, 1880-1920 (Pretoria: Unisa Press, 2001).

${ }^{26}$ Price, Making Empire, 1-12.
} 
instead established in an environment where Britons were surrounded by what was deemed a hostile state in the Republic of Natalia and some type of military group was necessary for communal security. ${ }^{27}$ Though, in retrospect, the comparisons in establishing this corps were strikingly comparable to their decedents a decade later.

This initial volunteer system was, nonetheless, representative of a more general system of military control outlined within the frontier society of nineteenth century South Africa. The Afrikaner concept of the "Commando", or a mounted militia or "burger force", was a staple of white society within Natal. Such early groups could hardly be categorized as a formalized military force, but instead a militia formed in times of crisis. Unlike the "commando", the composition and organization of the volunteer military corps were outlined under a system similar to the volunteer social clubs in Britain at the time. Trends from London would have made their way to the colonists through the press and letters home. One example of this trend was the creation of the "Queen's Own Volunteer Rifle Corps" in London in September 1848. Though the exact cause for the creation of the corps is unclear, the corps was formed in the environment of the 1848 Revolutions, and possibly as a preventative measure against hostile forces from both outside and within Britain's borders. Such inference is clear in the corps motto, attributed to Virgil: In Utrumque Paratus (“Prepared for either event"). ${ }^{28}$

Though anticipating the formation of the British Volunteer Corps in 1859, such corps were a continuation of the volunteer mentality which had existed since the Napoleonic period. The corps was reported in the London Monthly Times having received full support from the government and supplied arms and ammunition. So popular was the measure that

\footnotetext{
${ }^{27}$ Godfrey T. Hurst, Short History of the Volunteer Regiments of Natal and East Griqualand: Past and Present (Durban, South Africa: Know Publishing Company, 1945), 1-4.

${ }^{28}$ London Monthly Times, September 15, 1848.
} 
the Naval and Military Gazette announced a second corps was in the course of formation. At the same time as this British corps creation, the Natal Witness produced an editorial that inferred that if the colony was to protect itself; it must establish some type of standing force with similar organizations requiring "tact, time and patience." 29 The opinion of the editor remained that it would be better to rely upon "voluntary bands of the colonists, uniting, not from any desire for war, but from the calm conviction that disturbances may arise" over "the dependence to be placed on the native agency". ${ }^{30}$

Almost as a response to this call to arms, the following week the lieutenant-governor approved of the formation of a volunteers corps at Pietermaritzburg, appointing Walter Harding, crown prosecutor and future attorney general of the colony, to be lieutenant colonel. ${ }^{31}$ On September $8^{\text {th }}$, the first meeting held by Mr. Harding of this "yeomanry corps" set out regulation, future meetings, votes for officers, and even styles of uniforms with "Forty being the complement for a troop, and that number having been already enrolled, it is calculated that it will not take long to raise a second troop." ${ }^{\prime 32}$ The troops did drill, yet there was an overall lack of permanence to this "yeomanry corps" as it was named. Though the volunteers did follow many of the same methods used later by the formal volunteer corps of the colony, the unit never took part in any formal action, with the exceptions of acting as part of the proceeding for the funeral of Lieutenant-Governor Martin West in 1849 and a muster of troops for the Queen's birthday in May 1850. Slowly, more units were formed within the colony including the German settlers at Claremont, where they established fortifications, consisting of a ditch, wall and palisade of sufficient extent to admit all persons on the station, as well as the neighbours living in the area. The lieutenant-governor appointed a Mr.

\footnotetext{
${ }^{29}$ The Natal Witness, September 1, 1848.

30 Ibid.

31 “Government Notice, No. 80," The Natal Witness, September 15, 1848.

${ }^{32}$ The Natal Witness, September 8, 1848.
} 
Bergtheil to be captain, and the volunteer corps was raised under the designation of "Berhtheil's Volunteers". ${ }^{33}$ The emphasis on fortifications was illustrative of the growing tension across the border in the Zululand, which was exacerbated by the fear of an impending invasion from Mpande.

Despite this fear, there were those within the colony who had reservations about these new corps. Several of the wives of colonists were not as enthusiastic as their husbands to become "valiant sons of Mars" who "'had heard of battles! And long'd to follow to the field, Some warlike lord". ${ }^{34}$ By December 1848, several women, described as "primitive colonial ladies", or original settlers to the colony, reported to have formed an anti-yeomanry-corpsnon-marrying-association, with the intention of preventing the young men of the colony from joining the military organizations by promising to "neither [give] themselves, nor their daughters, nor their daughter's fortunes to any imitation soldier." 35 The reaction from the press was unforgiving, claiming these women were a dangerous symptom of "bleeding hearts" who were not taking into account the dangers of lacking an effective military presence within the colony, with such action leading many men "to inglorious resignation". 36 The measures, predictably, were unsuccessful, and the praise within the press continued to espouse the benefits of the corps, and their overall role in the protection of the colony, even when no military actions were taken.

It was this perceived field of protection that the volunteers provided which would remain a constant theme for the remainder of Natal's formative period. Despite having taken part in no real military engagements, the colonist who drilled as volunteers continued to

\footnotetext{
33 "Bergtheil's Volunteers", The Natal Witness, November 17, 1848.

${ }^{34}$ The quote was taken from an eighteenth century British play Douglas: A Tragedy by John Home and used in a scornful manner by the editors of the Witness to challenge the "excuse makers" who sided with those against the corps. The Natal Witness, July 10, 1849.

35 The Natal Witness, December 29, 1848.

${ }^{36}$ Ibid.
} 
assure themselves that they were doing their part to keep the "Zulu Threat" out of the colony.

This was only exacerbated by such unfounded reports that the Zulu knew of the volunteers' effectiveness, and were in fear of the volunteer's wrath. One account even claimed Mpande was holding off an invasion because of the yeomanry corps:

Since Panda [Mpande] has heard of the enrolment of this band, he show no disposition to come up to the mark,--and woe betide him if he did! He says infantry waddle like ducks, and he doesn't care for ducks! But as for the yeomen he won't come and feel the edge of their carving knives on any account. No wonder therefore that his impudence is brought down an inch or two. ${ }^{37}$

Such exaggerated confidence not only ensured continuing confidence in the volunteers, but also permeated the next decade of volunteer formation. Even following the outbreak of the Crimean War, there was a sense of "patriotic enthusiasm" from the British members of Natal's community directly associated with the war against Russia. This enthusiasm was fuelled by rumours of an advance on Durban by Russian privateers following the outbreak of war. From these patriotic elements and the confidence of the volunteers to prevent any attack, volunteer military organizations were formed between the later part of 1854 and throughout 1855. ${ }^{38}$ Despite official legal consent for the forming of the volunteer corps not being fully approved until the Volunteer Law of 1854, by the ratification of the law elements of these organizations had been formed and officers selected.

\section{Formalization of the Volunteers}

The formalization of the volunteer system came under Legislative Ordinance No. 8, 1854, approved by Lieutenant-Governor Benjamin Pine November 15, 1854, "to promote the

${ }^{37}$ The Natal Witness, April 27, 1849.

${ }^{38}$ George Russell, The History of Old Durban and Reminiscense of an Emigrant of 1850 (Durban, South Africa: P. Davis \& Sons, 1908), 197. 
establishment of Volunteer Corps for the defence of the District." ${ }^{39}$ Under this Volunteer Law of 1854 , anyone residing in the colony would be permitted to form a volunteer corps, with the specific need to develop rules, regulation, and bylaws that focused on duties, discipline, arms and equipment, and the number and ranks of officers and members. Units were permitted to elect their own officers, and would receive a maximum of six shillings for each day called out to actual service. With this legal formalization of the role of the volunteer corps within the colony, the colonial government, specifically in the form of the lieutenant-governor, was granted considerable power and authority over the volunteer corps. Troops that failed in their duties would be liable to a fine of up to $£ 10$, and returns for the number of men and horses in each corps would be forwarded to the lieutenant-governor twice a year. Such returns were necessary because the volunteer law also stipulated that when "any volunteer corps shall be reduced below twenty men, rank and file, for a continuous period of six months, it shall become, ipso facto, disbanded." $" 40$

Such formalization of the volunteer system was critical in the creation of colonial records and paperwork, especially given the fluid nature of the volunteer system. By the end of 1855 , there were five volunteer corps established, the Natal Carbineers and the Natal Rifles (spilt into two unites) out of Pietermaritzburg, and the Durban Volunteer Guard and Royal Durban Rangers out of Durban. Both the Carbineers, Rangers, and half the Rifles were cavalry units (though both sections of the Natal Rifles were commanded by Walter Harding). ${ }^{41}$ All in all, the total number of men in these corps by the end of 1855 was 339. Of these, the majority were part of the Durban Volunteer Guard numbering 150. Considering Natal's population in 1855 numbered around 1,200 Europeans, the percentages of men

\footnotetext{
${ }^{39}$ William James Dunbar Moodie, Ordinances, Proclamations Relating to the Colony of Natal, 1836-1855, with Notes of Reference (Pietermaritzburg: May and Davis, 1866), 487.

${ }^{40}$ Ibid., 554.

${ }^{41}$ The future Chief Justice of Natal was also a crown prosecutor at the time. "Military", Natal Blue Books, 1855.
} 
involved in these volunteer corps constituted a measurable proportion of the able bodied white men in the colony. Despite this strong showing initially, a year later the Durban Volunteer Guard had been disbanded and the total number of volunteers hovered around 200.42

Every volunteer corps typically began with the founding by a single individual who would become the commanding officer. The Durban Rangers were a unique case, with the founding officer being Benjamin Pine, Lieutenant-Governor of the Colony. ${ }^{43}$ Though not universal, volunteer corps would be formed and then submit their bylaws for the approval of the lieutenant-governor. Bylaws sometimes lagged behind the formation of units because of this need for approval and because of the necessity for the members of the corps to agree on elements of the bylaws. An early example of these bylaws can be found for the Natal Carbineers, formed in January 1855 and published their bylaws in March 1855. These rules outlined the makeup of the corps, the rules and regulations related to troop behaviour, and the parameters under which the corps could change rules and bylaws. Though strictly militaristic in tone, the language of these bylaws is telling of important elements to the volunteer corps.

Officers, including the lieutenant-colonel, major, adjutant, surgeon, and quartermaster would all be elected by the corps as a whole. Non-commissioned officers would be elected by their particular troop, consisting of no more than 50 men. Elections would take place typically at corps meetings, even with the greater formalization of the volunteers following the 1872 law. Promotions amongst officers would typically come from within the ranks, as was the case of promotion of Second Lieutenant T. Menne to first lieutenant and adjutant of

\footnotetext{
${ }^{42}$ Such a drop in numbers was presumably the reason for a minimum number to be set for the volunteer corps, since the volunteer law was amended in 1855 to allow the lieutenant-governor "in the event of his deeming expedient so to do, disband any such corps." Moodie, Ordinances, Proclamations, 488.

${ }^{43}$ Though Pine would act as unit colonel, he would never march with the unit into the field. That distinction would fall to the corps Captain, James Proudfoot. This tradition would continue for the majority of the corps existence, no matter who the lieutenant-governor was at the time.
} 
the Natal Hussars in $1877 .{ }^{44}$ Some officers, however, were elected from outside the corps directly to the position of unit commander, as was the case in the election of Mr. Clius Saner to the position of captain of the Victoria Mounted Rifles also in $1877 .{ }^{45}$ Once officers were selected, the notice of the election for officers would be forwarded first to the commandant of the volunteers and then on to the lieutenant-governor for final approval. In the case of a death of an officer "his successor shall be elected by nomination and ballot" and at least 14 days" notice would need to be given before a replacement was elected, providing enough time for candidates to be found and possibly make their case while vacancies of critical positions would be filled by temporary appointment of the commanding officer. ${ }^{46}$

This democratization of the volunteer organization was not exclusively limited to the election of officers. In the case of court martial, a president and six members would act as the jury. The president would be one of the officers, chosen on rotation, and the other six members would be selected by ballot from the corps as a whole. The quartermaster would act as judge advocate, and the final verdict would be forwarded to the commanding officer, which he would either approve and order sentence, or recommend the court reassemble and reconsider its findings. Far removed from the military tribunals of the British Army, such a system was implemented with the express purpose of allowing the members of these volunteer corps to have a say in the discipline of their unit and in doing so provide their own source of agency in the manner in which such discipline was implemented. ${ }^{47}$ Punishment was far removed from the "lash" and would typically take the form of a fine measurable by the

\footnotetext{
${ }^{44}$ Letter from Capt. Hill Natal Hussars stating $2^{\text {nd }}$ Lieutenant Menne had been elected $1^{\text {st }}$ Lieutenant and Adjutant, April 26, 1877, CSO 592, No. 1609, 1877.

${ }^{45}$ Letter from Victoria Mounted Rifles electing Mr. Clius F. Saner Captain of that corps, April 27, 1877, CSO 592, No. 1077, 1877.

46 "Proclamation No. 32, 1856", The Natal Government Gazette, February 13, 1856.

${ }^{47}$ Such systems still created a degree of "military values" along the same lines as the British Army, which was used in conjunction with military spectacle to significantly influence the social organization and perception of military institutions within British society. See Scott Myerly, British Military Spectacle: From the Napoleonic Wars through the Crimea (Cambridge, MA: Harvard University Press, 1996), 11.
} 
offence, usually to the maximum of $£ 10$. Such methods of military discipline did not mean, however, that the corps bylaws encouraged a negligible attitude toward military precision. These elements of the volunteers which would come under greater scrutiny during the AngloZulu War.

Some elements of precision can be found in the early bylaws of units like the Natal Carbineers. Twenty days were expected for drill and other operations yearly, taking place on a quarterly basis (in the case of the Carbineers, it would take place during the first five days of the week in march, June, September, and December for three hours in the morning and two hours in the afternoon). ${ }^{48}$ This was perhaps one of the most obvious elements of military precision. The trumpet would call at 6:30 in the morning, and troops were normally in roll call by five minutes till. Although the corps members were expected to wear a simple and inexpensive uniform, unit colours were implemented under the rules and bylaws. For the Carbineers, uniforms were "blue, with white facings, consisting of a shell jacket, overalls (strapped), helmet of leather, with white cover, and forage cap." ${ }^{\prime 9}$ To illustrate the demand for discipline and order, unit bylaws forbade members from appearing at muster in a "slovenly state". First offences were subjected to a fine of less than five shillings, while continuing transgressions would result in a court martial. This fine system is indicative of the major means to inflict discipline on a volunteer unit: through the money they had gained working in the colony.

The pay of the volunteers was measurable, but would quickly disappear over continuing offences. Absence from drill or service (unless provided a leave of absence ahead of time) would be fined up to $£ 10$. Insubordination, disobedience of orders, or even

\footnotetext{
48 Though this number was not universal, in many cases, volunteer officers lamented the limitation in drill days as an infringement to readiness of the corps for proper military service. (See below)

49 "Proclamation No. 32, 1856", The Natal Government Gazette, February 13, 1856.
} 
drunkenness on duty would result in a fine of up to two pounds. And if a trooper wished to leave the unit, six months' notice had to be given to the commanding officer. The only alternative would be to find a viable substitute, or (the quickest and most likely option for those able) pay a fine of five pounds. Ironically, the success of the unit rested largely in its ability to remain financially stable, and this fine system of punishment was the surest manner in which to keep the unit financially viable as a form of defence in the colony. This is conceivably why many corps were unable to last an extended period of time due to financial constraints and members unable to deal with the financial and temporal obligations.

Such structures to the volunteer bylaws remained relatively consistent throughout the 1860 s and into the 1870 s. Some exceptions and changes did take place, especially in regards to the supplies provided and the leisure activities associated with the corps. The Newcastle Mounted Rifles also presented in their bylaws a possibility for honorary members to join the corps for "an annual subscription of two Guineas, or make a donation of ten Guineas to the funding of the Corps." 50 The primary purpose of these memberships seems to be associated with the contest events hosted by the corps, as honorary members were "entitled to shoot for Prizes, but not vote at any elections of other business of the Corps." ${ }^{51}$ These honorary memberships increased the amount of funds available to the corps while encouraging larger participation in the annual shooting contests that were held between the corps. Such an inclusion also indicates the growth in popularity and numbers of corps by the formation of the Newcastle unit in October 1875. So much so that members were not allowed to shoot for prizes until they had been a member of the corps for six consecutive months, and, of course, paid all the fines due by them up to that date.

\footnotetext{
50 “Rule and Reg. Laws of the Newcastle Mt. Rifles,” CSO 531, No. 3004, 1878.

51 Ibid.
} 
Another change from early corps bylaws was the attempt to address the issue of supplies beyond general issues of uniforms and what equipment to be worn. The intricate details about the saddle arrangement for the Newcastle corps went beyond anything that was seen in the early bylaws of the Carbineers, with each member needing a saddle that could carry rifle holster, a double rein bridle, as well as a pair of goose-necked spurs about one inch long. Other required equipment included saddle blankets and knee halters for the horse, though such equipment would largely standard issue for any persons familiar with open range horsemanship. Changes with military technologies from the 1850 s were also evident, with officers being required to carry a revolver pistol, specifically a Colt revolver with 50 rounds of cartridge ammunition. The Colt Navy Model was only recently adopted in 1854, but had become a standard weapon during the ensuing decades.

Perhaps the final change that can be seen in later bylaws rested on the continuation of the democratization process in the volunteer system. Because the corps was a system relying on sporadic meetings that occurred quarterly at best, annually a committee of the officers and five other members of the corps would be formed that would function for the remainder of the year as regulators of finance, as well as "other business of a civil nature appertaining to the Corps." ${ }^{\circ 2}$ The committee would be elected these five members on an annual basis, continuing the tradition of allowing the basic soldiers some say within unit business.

Though there were many unique individuals in the early volunteer corps, one of the most well documented accounts of the early formation of the volunteers was outlined by George Russell, a long-time resident of the colony, in his history of Durban. Russell provides many extensive details on the makeup and early years of the Durban Rangers (later the Royal Durban Rangers following its official proclamation in February 1855). The composition of

52 Ibid. 
the officers of the Durban Rangers was not necessarily based on military experience. Two of the officers elected on April $13^{\text {th }}$ did have previous military commissions. Patrick J. Maxwell, a former officer in the Austrian military, was made lieutenant, and Robert Tatham, member of the Cape Mounted Rifles, was selected as military instructor sergeant. ${ }^{53}$ The viability or success of such military experience can be questioned, and the commitment that many of them had to the organization remains uncertain, but such appointments are illustrative of the advantage of previous military experience in the election of officers.

If military drills and meetings were intended to be a common occurrence within the organization, by July 1855 , the Rangers had settled into having only quarterly meetings which included parade drills and firing practice. Of course, these meetings were also associated with banquets and entertainment, as in July when Captain James Proudfoot hosted an event at Boulton's Hotel in Durban. ${ }^{54}$ Also represented at this event were members of the $45^{\text {th }}$ Regiment out of Fort Napier and the Natal Carbineers.

Following the formation of the Royal Durban Rangers, Russell was also involved in the infantry corps dubbed the Durban Town Guard. Mustered in October 1854, the corps included three companies totalling 150 men. The designation for the unit was quickly changed to the "Durban Volunteer Guard" and they began taking part in drills soon after their first muster. ${ }^{55}$ Russell, in his history, recalls that individuals who volunteered for this corps were drawn from multiple professions and backgrounds. Brass forgers, bakers, carpenters, and other workers from the colony joined up. Former military men, largely retired army

\footnotetext{
${ }^{53}$ Russell, The History of Old Durban and Reminiscense of an Emigrant of 1850, 198.

${ }^{54}$ The Natal Mercury, July 11, 1855

${ }^{55}$ Russell, The History of Old Durban and Reminiscense of an Emigrant of 1850, 200.
} 
pensioners, provided instruction on military order and marches, in some cases in exchange for land from the War Department as compensation. ${ }^{56}$

This tactic was nothing new, and multiple examples can be found in the archives of colonial officials attempting to find work or land for former soldier settling in the colony. Major Dartnell, commandant and inspector of the volunteers from 1873 to the late 1880 s, was formerly a soldier in the $27^{\text {th }}$ Infantry Regiment. An H.O. Newland requested from the lieutenant-governor an appointment in a colonial corps while part of an imperial militia in Ireland in $1877 .{ }^{57} \mathrm{Mr}$. Newland claims to have been a resident of the colony for a number of years before his arrival to Ireland, but there is no evidence that he served in the volunteers as an officer of any kind. He could, however, have served in a trooper capacity. Even soldier stationed at Fort Napier may eventually decide to settle in the colony, as was the case with a Mr. Rayson who was permitted at the end of his service to remain in the colony of Natal and act as a settler. ${ }^{58}$ Whether Mr. Rayson remained in the colony for long or joined the volunteers is unknown, but he provides another example of the military men who were available within the colony. This crop of soldiers in the colony would only multiply as its population grew, and their presence could explain the increase in discipline and organization of the corps after their initial formation in the $1850 \mathrm{~s}$.

\section{Questions of Discipline and Organization}

The discipline and organization of these volunteer corps, despite the presence of former military men as instructors, began to break down almost as quickly as the units were formed. Even by October 1855, letters to the editor appeared in the Natal Mercury, criticizing

\footnotetext{
56 Though in 1867, the Secretary of State issued a letter from Horse Guards stating that the Commander-in-Chief would no longer issue letters to retired officers for the purpose of obtaining land in British Colonies. "Government Notice", Natal Blue Books, February 1, 1867.

${ }^{57}$ H.O. Newland, North Cork to the Colonial Secretary of Natal, April 19, 1877, CSO 590, No. 1508, 1877.

${ }^{58}$ H. Hallam Pass, District Adjutant of Natal to the Hon. Colonial Secretary, April 19, 1876, CSO 549, No. $1044,1876$.
} 
the lack of proper training time and drills, as well as lamenting how the corps might "with efficient management and proper co-operation, have been of the greatest value to the town" in terms of colonial defence ${ }^{59}$ An opportunity had been lost, to some colonists, to create an effective volunteer system which would properly contribute to Natal's defensive institutions, while also helping to stabilize Natal as it established itself as a colonial state. The most obvious cause for this lapse in discipline was the minimal incentive placed on the members of the organization to continue to take part in military activities. George Russell, a member of the volunteers and future quartermaster, gives an account of one incident involving a baker named Sandy Forbes who simply ceased to answer his name at roll call because of the public scorn put upon him for coming to drills with a broom instead of a rifle. This reveals how some individuals simply left the units or refused service, despite their good intentions, without any tangible repercussions from the units. ${ }^{60}$ This lack of discipline and failure to create a cohesive military unit for the defence of Durban gave credence to the heightening concerns by the colonists for the necessity of a proper defence corps. As indicated above, problems did not lie entirely with the organization and discipline of these militias, but also with the lack of proper distribution of equipment, arms, and ammunition.

George Russell concedes that the early military supplies provided for the Durban Rangers by the government came in the form of "surplus stores," or obsolete arms and supplies from Fort Napier and the Cape Mounted Rifles. The weapons provided were a heavy Brunswick pattern carbine that frequently jammed, making it impossible to be reliably used on horseback. The swords, old dragoon sabres, were only useful to the skilled swordsman, resulted in some cases men being thrown from their horses as they cut downward. ${ }^{61}$ Supplies for the Durban Volunteer Guard were no better, and in many instances worse. If uniforms

\footnotetext{
${ }^{59}$ The Natal Mercury, October 26, 1855.

${ }^{60}$ Russell, The History of Old Durban and Reminiscense of an Emigrant of 1850, 201.

${ }^{61}$ Ibid., 197-198.
} 
were supplied to the unit, they were mostly composed of remnants of sailors' coats with some alterations. Hats were tailor made and fashioned in the style of the French kepi, and a pewter insignia of "DVG" was sewn to the front. Trousers, however, were not provided, and it was assumed that the men would wear a standard grey colour. Firearms were not provided, and most troops brought their own weapons from home, ranging from rifles to rabbit guns. Those who did not own a firearm used wooden guns for training. ${ }^{62}$ The failure to obtain uniform firearms directly impacted the nature of how training could be properly implemented. Though this would eventually be changed and the corps would allow for certain funds to pay for the volunteers, costs remained a contentious issue for much of the early corps. ${ }^{63}$ This was due to the colonial government's lack of additional funding for much of the $1850 \mathrm{~s}$ and $1860 \mathrm{~s} .{ }^{64} \mathrm{It}$ was only exacerbated by the inability of the colonial government to allow for additional cost to be absorbed by the state. Even when the corps were able to regularly drill and provide their own uniforms, they sometimes incapable of dealing with additional expenses.

In June of 1873, the Durban Rifle Guard, formed in July 1861, requested from the colonial government additional funds for the expense of procuring a bandmaster and the musical instruments for the band. The memorial, drafted by Colonel H.J. Meller, contended that the request, combined with the procurement of uniform for the said band, had driven up the additional cost of the corps by $£ 150 .{ }^{65}$ More drastically, the same year the Victoria Mounted Rifles also requested funding from the government for the purpose of pay assistance

\footnotetext{
62 Ibid., 200-201.

${ }^{63}$ Under the Volunteer Law of 1872, every member of the volunteers was provided "a breech-loading rifle, to be supplied by the Government on receipt of a bond for its safe custody and return."

${ }^{64}$ Between 1858 and 1872 , the government spent less than $£ 2000$ on pay for the volunteer corps, despite their numbers increasing to over six hundred by 1870 . Perhaps the greatest disparity occurred in 1861 when the number of volunteers reached 449 (more than double the previous year) and the total funds provided remained $£ 500$. Minute: Attorney General, Natal: 'Return of Volunteer Corps \& their respected strength' and 'Expenses of Volunteer Corps', AGO I/8/20, No. 196A/1878.

${ }^{65}$ Legislative Council, Natal, Document No. 22, "Memorial from Members of Durban Rifle Guard to His Excellency the Lieutenant-Governor, Praying for Pecuniary Assistance from Public Funds, June 8, 1863," NCP $4 / 1 / 1 / 2,1863$.
} 
from the colonial government. Though there were a few corps that were established that did not receive the minimum government funds, these were usually very small contingents of mounted men that rarely lasted more than a few years. The Victoria Mounted Rifles had been formed in 1861 and presented their case to the lieutenant-governor for modest pay assistance for clothing, accoutrements for both man and horse, additional cartouche (ammunition) boxes and belts, and perhaps most importantly, tents for 50 men. ${ }^{66}$ Major George Adams, commander of the corps, had planned for his men to "camp out for a week at some distance from any settlement of Colonist in order that all members may have an opportunity to of knowing by actual experience what would be required and what they might have to do for their own comfort". ${ }^{67}$ Neither the pay, tents, nor boxes were immediately provided, due to the limitations place on funding for the volunteers at this time. The lieutenant-governor forwarded the request for the next legislative council session and made appropriate inquiries on the acquisition of the tent, but there was no immediate answer for these supplies.

These incidents illustrate some of the major limitations placed on many volunteer corps during this early period of the colony. However, the purpose and motivations of these units can still be seen in the acclaim placed upon the troops by their commanding officers. Major Adams does not request additional remuneration for the time devoted to drill and the like, but instead hoped to receive the funds for the benefit of the corps as a whole. Colonel Meller argued that additional funds were only a small segment of the overall cost of continuing the volunteers and that the volunteers had "incurred this liability in addition to the sacrifice of their time, solely for the public good, and the public have derived the benefit". ${ }^{68}$ These examples highlight the driving force behind most of these volunteer organizations: the

\footnotetext{
${ }^{66}$ Legislative Council, Natal, Document No. 21 "Correspondence Between Officer Commanding Victoria Mounted Rifles and Colonial Government Related to Allowance of Pay and Military Tents to the Corps, January 13, 1863," NCP 4/1/1/2, 1863.

67 Ibid.

${ }^{68}$ Legislative Council, Natal, Document No. 22, NCP 4/1/1/2, 1863.
} 
continuing need for collective security outside of government involvement. Despite the limitations placed upon the corps by funding and the lack of equipment, the quintessential ideals of the volunteers of maintaining the defensive structures of the colonies remained. By working through these early problems, and in some cases highlighting them to the government, the volunteers, whether by perception or actuality, were able to establish their place as a key pillar of colonial control within the colony of Natal. These would not, however, be the last set of administrative and practical problems that would face the volunteers during this formative period.

\section{Limitations on Firearms and Ammunition}

During the 1850s when ammunition was not supplied by the government, volunteers were discouraged from forging their own bullets. Attendance at training exercises also became scarce when volunteers were required to purchase their own powder. Such constraints illustrate the limitations on gunpowder, guns, and ammunition during this early period, and would remained a pivotal issue on how firearms and ammunition were regulated within the colony for much of the $1850 \mathrm{~s} .{ }^{69}$ Laws and regulations related to the sale and distribution of gunpowder remained a common concern in the colony until the gunpowder trade was monopolized by the colonial government in $1859 .{ }^{70}$ Before that time, the provisions of gunpowder were handled by private traders from the Cape Colony and the Transvaal. Colonial ordinance had been put in place to restrict the distribution of firearms within the colony in 1851 , forbidding the shipment or selling of arms or ammunition without the express

\footnotetext{
${ }^{69}$ The use of gunpowder and firearms by Sotho forces in Southern Africa and its connection to the evolution and power structures between indigenous groups, the British, and the Afrikaners has been insightfully examined in Anthony Atmore and Peter Sanders, "Sotho Arms and Ammunition in the Nineteenth Century," The Journal of African History 12, no. 04 (1971): 535-544.

${ }^{70}$ The Natal Mercury, September 1, 1859.
} 
permission of the chief customs officer. ${ }^{71}$ Because the penalties to the 1851 ordinance had been so steep (those without proper authorization would be given a penalty of $£ 500$ ) it would have been particularly dangerous to purchase arms and ammunition from illegal or nontraditional sources. ${ }^{72}$ Such limitation on equipment would lead to suggestions that the corps be completely reorganized, shifting toward a system in which ammunition would be provided for training along with pay. ${ }^{73}$

Even by the mid-1870s, there was a tight hold on the distribution of ammunition to the volunteers. When the imperial troops stationed at the colony were outfitted with the Martini-Henry rifles in 1875, Major Dartnell, Commandant and Inspector of the Volunteers, made a request for the Sneider carbine ammunition from the control department. Because of the limitation placed on the amount of ammunition provided for each troop, limited to 50 rounds per man for cavalry and 100 rounds per infantryman a year, Commandant Dartnell was initially unable to procure the additional ammunition that was no longer needed by the imperial garrison. Under typical protocol, the supply of ammunition would be sent back to England and distributed within the British Army. Dartnell, however, felt that "there could be no objection to the colonial government purchasing the whole of the Snider ammunition remaining in the colonial stores" (some 100,000 rounds) and providing their use for the volunteers. ${ }^{74}$ Initially, there were objections from the control department as well as the colonial government. A major question rested on why the volunteers would need so many rounds for practice when 50,000 was the annual allowance. Eventually, it was decided that the rounds would be placed in reserve within the colony in case of emergency, but the

\footnotetext{
${ }^{71}$ BPP: Further Correspondence Related to the Establishment of the Settlement of Natal, Enclosure in No. 10: Extract of a Despatch from Lieut.-Governor Benj. C.C. Pine to his Excellency the Governor-General, Cape Town, dated Government House, Natal, January 12, 1852.

72 Ibid.

${ }^{73}$ This reorganization will be discussed below with the formalization of the volunteer laws in the 1850 s and further reforms in the 1870s.

${ }^{74}$ J. Dartnell, Major, Com. Volunteers to the Executive Council, February 10, 1875, CSO 512, No. $919,1875$.
} 
incident still illustrates the difficulty in which the volunteers worked within the ammunition laws of the colony.

This issue of whether or not it was proper to supply the volunteers with certain arms and ammunition was nothing new in 1875 . Two years earlier, before the full distribution of the Martini-Henry rifles amongst the British Army, Lieutenant-Governor Musgrave, on behalf of the legislative council, requested 200 Martini-Henry rifles and 500 cavalry carbines. These arms would be provided specifically for the volunteers who were being reorganized under the new volunteer law (see below). The request, however, was initially denied and altered to the Sneider rifles, "in lieu of the Martini-Henry, which are not yet ready."75 The colonial government responded that it would accept such a change, yet the colonial government questioned such a decision based not only on correspondence received from the War Office which directly stated that the Martini-Henry rifle had been adopted for imperial service and was being manufactured, but also because, once again, of the issue of ammunition. Though the Sneider rifle was "undoubtedly a most efficient weapon...superior to any rifle in use by other European armies", if the Henry rifle was adopted within the next few years, the colony would face an unwanted surplus of Sneider ammunition which would be useless with the Henry rifle. ${ }^{76}$ Though the volunteer infantry was eventually supplied with Martini-Henry rifles, the carbines would remain Sneider for the next several years. Not surprisingly, the ammunition surplus that was anticipated occurred two years later with Commandant Dartnell's request for the imperial garrison's surplus of Sneider carbine ammunition.

\footnotetext{
${ }^{75}$ Legislative Council, Natal, Document No. 37 "Correspondence with the Secretary of State for the Colonies on the Subject of the Supply of Martini-Henri Rifles to the Volunteers, December 2, 1873," NCP 4/1/1/3, 18731874.

${ }^{76}$ Ibid.
} 
The incident, though minute, is demonstrative of the supreme difficulty the volunteer organizations had with both properly supplying the members of the corps, but also keeping the units along the same parameters as the British military system, something that seemed to not be a major concern for the colonial authorities at Downey Street. The causes behind these actions remain unclear, but could be a result of colonial thrift, or an attempt to increase colonial control within Natal. Whereas cost saving measures remained a consistent theme during the formative period of the colony of Natal, it was also possible that from a central administrative or imperial perspective, a large number guns or ammunition within the colony amongst the white settler population could become a threat to central authority. There is, however, little evidence that the concerns for firearms was part of a fear of a white uprising, but instead linked to the means through which African could access firearms through white intermediaries. ${ }^{77}$

Another major difficulty rested on the existence of rifle associations within the colony of Natal. In many cases these rifle associations were composed of the same individuals who took part in the volunteers, and were established with the express purpose of allowing venues for firearms practice. Law 19 of 1862 promoted the establishment of rifle associations for the defence of the colony, though these associations were also formed along similar lines of the volunteer corps as a type of social club that masqueraded as an element of Natal's defensive institutions. One such group, the Natal Coast Rifle Association, on multiple occasions made extensive requests to the colonial government through the commandant of the volunteers. In 1875 , they requested the installation of new target plates for practice range, stipulating that there were not enough plates to make a "first class target". ${ }^{78}$ Such supplies could be provided because the rifle associations were subsidized by the Natal government. The Natal Coast

\footnotetext{
77 This will become a greater concern within the police institutions of the colony, as will be discussed below. ${ }^{78}$ Secretary Natal Coast Rifle Association to the Colonial Secretary of Natal, Durban Hotel, October 16, 1875, CSO 530, No. 2934, 1875.
} 
Rifle Association would receive $£ 50$ annually to support the purchase of ammunition so the men involved could continue to be prepared for the possible outcome of invasion, and have the rudimentary training necessary to act as a possible second line of defence on the chance of the failing of the volunteers. ${ }^{79}$

With this overall expectation for funds and ammunition from the government, it came as a surprise when a request for more ammunition in June of 1878 was met with some resistance from the controller of arms. The Natal Rifle Association had just received 20 Swinburn Henry (a derivative of the Martini-Henry) rifles and submitted a request for 500 rounds at cost. The controller of arms would typically have no major problem such requests in light of the special relationship which developed between the rifle associations and the controller of arms, presumably because the controller of arms was part of or knew several members of the rifle association. Due to the number of rounds being requested, however, the controller of arms needed to confirm his the requisition with the colonial government. Despite some small reservations from Commandant Dartnell on the number of rounds requested, the rifle association was permitted to purchase the ammunition at $\operatorname{cost}{ }^{80} \mathrm{Such}$ cooperation between civilians and the government over the issue of ammunition illustrates the degree that firearms and ammunition in the hands of government approved individuals had meliorated by the 1870 s compared to the early restrictions of the 1850 s.

Keeping a solid control over the number of firearms within the colony and in the possession of the volunteers would remain a major issue within the colonial government even to the build-up to the Anglo-Zulu War. Even by July of 1878, there were continuing questions as to the number of firearms in the possession of the volunteer corps. The attorney

\footnotetext{
${ }^{79}$ D. Nolan, Secretary of Natal Coast Rifle Association to the Colonial Secretary of Natal, Durban, February 21, 1876, CSO 544, No. 577, 1876.

${ }^{80}$ Minute Papers: Secretary of Natal Rifle Association: Acknowledges receipt of 20 Swinburn Henry Rifles, June 21, 1878, CSO 647, No. 2207, 1878.
} 
general, in response to the Home Defence Bill of 1878, even requested from the commandant a systematic summary of the number of firearms possessed by the volunteers since 1865 , both accounted and unaccounted for. By 1877, an average of 603 rifles per year had been issued. ${ }^{81}$ In comparison, cost of issuing these firearms had remained around $£ 2000$ for this period. ${ }^{82}$ Some weapons were listed as unaccounted for, though the commandant does not go into considerable detail about this issue. What this request does illustrate is that firearms, and the limitations posed on those firearms, were a central component of the volunteer organization, though not the only component of their existence. The limitations on firearms, though an initial hurdle in the corps existence, was eventually overcome with greater formalization. Such formalization not only characterized the growing colonial government and colonial population, but also provided a clear avenue to understand the changing role of the volunteers within the colonial state. Firearms and ammunition, however, was only one of the early limitations that defined the volunteers. There remained basic questions, even within the first decade of the volunteer's formation, over the commitment and readiness of the men involved in these corps to take part in military manoeuvres and remain a viable component of Natal's defensive institutions.

\section{Readiness, the Fear of Invasion, and the Volunteers}

In 1859 within the pages of the Natal Mercury, a summary of a drill book for volunteer riflemen in England was presented as an overview of the requirements and necessities to create a successful volunteer unit. It featured the opportunities for promotion for fulfilling ones duties, the levying of fines for volunteers that do not take part in drills and

\footnotetext{
${ }^{81}$ This does not imply that over 9,000 rifles were given out during this time, because corps members would have to return their rifles if they left the unit and older members would not be given more than one rifle a year. Instead, the average illustrates how many armed volunteers were accounted for by the Commandant during this period between 1865 and 1877. Minute Papers: Attorney General, Natal: 'Return of Volunteer Corps \& their respected strength' and 'Expenses of Volunteer Corps', AGO I/8/20. No. 196A/1878.

${ }^{82}$ With the exception of 1875 , likely due to changes in the volunteer structure recommended by the Defence Commission of 1875 which called for a gradual implementation of new weaponry with the volunteer corps (see below). Ibid.
} 
other training, the proper implementation and distribution of arms, and most importantly, discipline. Without discipline, the volunteer corps would become an "armed mob, more dangerous to themselves than others." 83 Published in 1859 , these suggestions seem to be a direct commentary on the dismal situation within the volunteer corps a few short years before. Volunteers had many problems with the aspects of "soldiering." Some had difficulty with the complex cross belt that held a cartridge box, bayonet, and cap pouch. Others struggled with the procedures for loading the muzzle musket. ${ }^{84}$ But perhaps the most striking problem lay in the failure or repeated failures of these infantrymen to fire the large calibre muskets of the British infantryman. Notoriously inaccurate, these muskets greatly differed from the smaller calibre firearms the volunteers would be accustom to when hunting small game within the colony, some having difficulty in even pulling the trigger. And when the trigger was pulled, it sometimes knocked a man back several paces. Consistent accuracy was nearly non-existent during target practice, as evidence by low expectations: "the man whose nerves and muscles enabled him to hit the target twice in succession at 150 yards was regarded as a marksman." 85 Of course, a bullseyes was seen simply as a "chance shot" and no indication of any accuracy of proficiency with the firearm. If such experiences were typical for most military recruits during this period, since the volunteers were never consistently trained, they likewise remained unaccustomed to the discipline or military tactics of the corps, as well as simple practice of firing their weapon. Such problems would not be solved in the short term. Even by the 1870 s, the level of training and skills among the volunteers was still a point of contention, as was outlined in one episode in a paper on colonial defence:

I was herding sheep when the volunteers had their meeting at Estcourt, and a man of Langabalele's [sic.] named Newabyala and others were returning from witnessing their evolutions. This man said, if that was the only way they managed their shooting,

\footnotetext{
${ }^{83}$ The Natal Mercury, October 13, 1859.

${ }^{84}$ Russell, The History of Old Durban and Reminiscense of an Emigrant of 1850, 203.

${ }^{85}$ Ibid., 204.
} 
and those were the plains on which they shot, Langalabalele's [sic.] people could easily manage them. ${ }^{86}$

Such an account was taken shortly before the Langalibalele Rebellion, but still illustrates the considerable lack of confidence possessed by many for the volunteers to successfully complete their task as a pillar of colonial defence. ${ }^{87}$ There was, however, a growing concern by October 1855 of a Zulu invasion of Natal caused by growing power struggles within the region, including the threat of civil war within the Zululand spilling over into Natal.

For European colonists, there was a real apprehension of war within the Zululand directly impacting the lives and livelihood of the colonists. Because of the proximity between these two areas, any major political shift would greatly impact the safety and security of the colony as a whole. A deeper anxiety was felt by the colonists of the possibility that if Mpande (referred to as "Panda") was defeated in his personal power struggles of the 1850 s, he would attempt to take refuge in the district of Natal. In 1840, Andries Pretorius had aided in the overthrow of the Zulu King Dingane and was partially responsible for the installation of Mpande as king. ${ }^{88}$ Pretorius had, in fact, proclaimed Mpande King of the Zulu and stipulated that Mpande would act as a vassal to the Natal Republic. ${ }^{89}$ During Mpande's exile in 1838 from the Zululand, where he was forced to flee the country and consolidate his forces, 17,000 Zulu fled the war torn region and sought safety in Natal. Many remained once Mpande returned to Zululand. Colonial views that the African population was already on the brink of overwhelming the European colonists were only exacerbated by the news of the possibility of

\footnotetext{
${ }^{86}$ Extract from Colenso's blue book, p. 64, Enclosed in H. Stainbank to the Colonial Secretary, April 22, 1878 , CSO 638, No. 1426, 1878.

${ }^{87}$ The Langalibalele Rebellion of 1873 will be discussed at length later in this chapter.

${ }^{88}$ Sullivan, The Native Policy of Sir Theophilus Shepstone, 16.

${ }^{89}$ Wilson and Thompson, The Oxford History of South Africa, 263.
} 
yet another Zulu exodus following internal political conflict within the Zululand. ${ }^{90}$ Rumours even began to circulate within the press of a possible invasion by Mpande from the Zululand into Natal. Such speculation elevated concerns within the colonial population about the readiness of Natal's defences against outside attacks, particularly in Durban, which was outside of the protection of Fort Napier.

Colonial Secretary William Sargeaunt sent his assurances to the offices of the mayor of Durban in regards to the unrest taking place in the Zululand. These assurances first included a dismissal of the possibility of attack by Mpande, largely due to the impassability of the Tugela River due to weather. The government's concern for the colonies military preparedness was minimalized by the listing of the organized defences which already existed within the colony. In the primarily Afrikaner counties, composed of holdover farmers from the Trek period, the rigid military structure that existed within these groups gave, according to the colonial government, full assurances of their military preparedness, as these groups would organize "under the field cornets of their respective wards" into commando units that would function as a local militia. ${ }^{91}$ Such an organizational structure was not present in the more British counties, composed of settlers who had more recently arrived in the colony. Yet the colonial secretary boasted of the presence of the British military at Fort Napier as well as the volunteer corps which had been recently established.

The colonial secretary also emphasized the presence of a male population that would be willing to volunteer at a moment's notice to defend their respective towns. These men, however, would be "comparatively useless in the event of an invasion or other emergency" because of their ill-discipline and lack of proper training. ${ }^{92} \mathrm{With}$ this declaration, the colonial

\footnotetext{
${ }^{90}$ The Natal Mercury, October 12, 1855.

${ }^{91}$ The Natal Mercury, October 26, 1855.

${ }^{92}$ Ibid.
} 
government of Natal in essence created a recruitment call for the volunteer military organization. All males (assumingly white) between the ages of 16 and 60 were called upon to join their local volunteer corps, without delay. Offers of uniforms and equipment were made (without reference to the second hand items which were likely given), as well as pay and rations if the corps was to be called up in the case of colonial defence. The stipulation, however, was made that at least three years of service and a considerable amount of drilling would be required for the volunteer corps to be seen as a success, and achieve some sense of military discipline. The final note by the colonial office allays fears once again, stating that this call to action would be a "fitting opportunity of arousing the colonists of this district of their duty [as opposed to] from any fear of an invasion from Panda [Mpande]." ${ }^{93}$ Within this report, however, there is no mention of the indigenous forces that could be called up within the colony. This could be because indigenous forces were largely perceived to be used only in internal matters, such as the acquisition of cattle from chiefs as a form of punishment within the colony. It is also possible that the colony simply dismissed the importance of the African military units in the facilitation of colonial defence. The complete absence of this large section of the colonial military structure leaves question of how these indigenous military organizations were perceived in not only the press, but also the government's own reporting. ${ }^{94}$

Despite the actions of the local volunteer corps receiving praise, there still remained a greater demand to organize and standardize the corps within Natal. The culmination of this in many ways would be the volunteer laws of 1872 , but there was a gradual attempt to professionalize the volunteers over the decades between the founding of the first corps and the Anglo-Zulu War. A minor example occurred in 1864 when Horse Guards made addressed

\footnotetext{
93 Ibid.

${ }^{94}$ This issue will be addressed in more detail later in the dissertation (Chapter Five and Six), but should be mentioned now as part of the "silences" which existed in the colonial accounts during this period.
} 
the volunteer corps in Natal. New regulations in the British Army applicable to the officers of the Army and Royal Marines were applied to the officers of the militia, yeomanry, and volunteers, or simply “All Officers of Yeomanry and Volunteer Corps rank, as juniors of their respective ranks, with Officers of the Regular, Fencible, and Militia forces." 95

The brief recruitment call of the 1850 s did nothing to solidify the readiness of the volunteers, as both discipline and turnover continued to be major shortcoming of the volunteers. Turnover was simply inevitable in a civilization, volunteer based organization, but left many corps simply unmanageable. Between 1865 and 1870, an average of three officers a year resigned or were no longer in service to the colony. These resignations did not originate from one unit, or evidently coincide with any particular event in the colony, but instead were indicative of the fluid nature of many volunteer's membership to the corps. Officer positions, though consistently filled throughout the 1850 s and early 1860 s, became more and more commonly vacant by the early 1870 s, especially in the case of lieutenants and second lieutenants. The Alexandra Mounted Rifles, formed in 1863, had the positions of second lieutenant and surgeon vacant from 1866 to 1873 , and continued to lack a surgeon until $1881 .{ }^{96}$ Though the new Volunteer Law of 1872 and the arrival of Major Dartnell as the new commandant and inspector of the volunteers would attempt to rectify many of these problems, difficulties would continue to mount creating greater frustration with the volunteer system.

\section{Possible Solutions}

An invasion from Mpande in the 1850s never materialized, despite fears from within the colonial population. The call to arms from the colonial office also seemed to have little

\footnotetext{
95 Published as a public notice in The Natal Government Gazette, March 7, 1865.

96 The position of second lieutenant was also very sporadically filled during the 1870s, despite the troop's strength remaining around fifty men for much of this period. Natal Blue Books, 1865-1877.
} 
long term impact. The Durban Volunteer Guard remained ill equipped and in disrepair until it eventually broke up following its last meeting in July $1856 .{ }^{97} \mathrm{~A}$ second volunteer corps was established in 1859 under the name the Durban Rifle Corps, with many of the same members, including George Russell who was made a staff officer for Colonel Henry James Mellor. Similar attempts were made in Pietermaritzburg, but with its proximity to Fort Napier "Maritzburg" did not seem to express the same degree of "martial fever."98 The funding and military preparedness of this group seems much greater than the original volunteer corps, despite their initial enrolment of only 110 men. Enfield Rifles were provided for the unit as well as uniforms ordered from England, of a much better quality than the second hand items of the first infantry corps. According to George Russell, the corps increased in size and proficiency, eventually taking part in multiple public functions, including taking part in a military parade for Prince Alfred during his visit to the colony in 1860, as well as "giving off a branch to the Artillery." 99 Despite these successes, financial difficulties of the mid 1860 s resulted in the corps eventual demise.

The attitudes within the colony regarding the failures of the volunteer corps (at least in Durban) created an opportunity for individuals to put forward their own views on how to deal with military security within the colony. One of the most striking views in regards to military reform came in the form of a series of editorials by an anonymous contributor to the Natal Mercury who signed as "One of the People." His solution to the military issue as well as concerns regarding the indigenous population was to form a "Natal Guerilla Corps" within the colony. The writer has an obvious fear of the large indigenous population within the colony, making clear that the Royal Durban Rangers and Natal Carbineers, as well as the military stationed at Fort Napier, would not be well suited in dealing with a large indigenous

\footnotetext{
${ }^{97}$ Russell, The History of Old Durban and Reminiscense of an Emigrant of 1850, 204.

${ }^{98}$ The Natal Mercury, October 4, 1859.

${ }^{99}$ Russell, The History of Old Durban and Reminiscense of an Emigrant of 1850, 432.
} 
attack (whether external or internal). According to the writer, "savages are enemies that cannot be dealt with according to European warfare, but require to be dealt with in an entirely different manner." 100 The Africans, in his mind, were capable of a different type of warfare with different standards. With a guerrilla corps, a type of commando unit which would roam the countryside in a less organised fashion, the colony would be able to maintain its safety in the event of outside attacks in conjunction with internal strife. In the opinion of this writer, such a unit would allow for the colonists to respond to attacks from the Zululand, or internal uprisings from Natal's African population.

This is possibly why there continued to be a commando presence in the colony despite the existence of the volunteer corps. In 1863, the colonial government formalized the existence of these commando or "burgher forces" under Law No. 26, 1863 to promote the "Establishment of a Volunteer Mounted Burgher Force for the Defence of the Colony."101 The burgher forces were a continuation of the commando tradition that had existed in Natal since before the British arrival and would have been a strikingly similar system as the one suggested by "One of the People." The creation of this force was not particularly new. The Cape Colony had also experimented with a combination of volunteer, burgher, and mounted police during the same period. In most cases, Afrikaners would form commandos in the rural areas while volunteers would be from the towns and predominantly British. Nevertheless, this force that was established was distinct in many ways from the volunteer corps. Though also based largely on regional recruitment, the burgher forces were more irregular forces than the main volunteer contingent. They were not commanded by an elected officer system, but instead reported to the local field cornet when needed. Drills were not required, and

\footnotetext{
${ }^{100}$ The Natal Mercury, September 20, 1860.

${ }^{101}$ The law was amended in 1865, but in essence of the law remained largely the same with minor alteration. Charles Fitzwilliam Cadiz, Natal Ordinances, Laws, and Proclamations: Compiled and Edited Under the Authority and with the Sanction of His Excellency the Lieutenant Govenor and the Honorable the Legislative Council (Pietermaritzburg [S. Africa]: WM Watson Government Printers, 1891), 522.
} 
individuals who wished to join only needed to apply for admission to the field cornet and receive a certificate of enrolment. Uniforms, horses, and weapons were provided by the individual, and pay of up to six shillings was only given when the forces were deployed. Fines (of the maximum of 20 shillings) were still handed out to individuals who mustered with "arms and accoutrements in an unserviceable or slovenly state", or for a horse that was not "serviceable and trained to stand fire". Members who were found guilty of insubordination or disobedience of orders in the field could be fined up to $£ 5 .{ }^{102}$ In essence, this burgher force was a compromise to some extent between the colonial government and the Afrikaner population that allowed many who did not approve of the British military system to retain their own methods of combat. The commando tradition, which stretches back to the time of the Great Trek, was more in keeping with the voluntary militia system which imposed itself less strictly on the Afrikaner population.

Despite this compromise between the colonial government and the Afrikaner population, the major limitation of these burgher forces was their role as a defensive force. Rarely would they be required to leave their home district, and would never leave the colony. Instead, their primary purpose was to act as a supplemental force to the other elements of defence that existed in the colony. In light of this limitation, many European settlers would continue to see the opportunities presented in the volunteer corps as a means of not only maintaining colonial control, but also acting as a fundamental pillar in colonial security to threats within and outside the colony.

By the 1870 s, others would see the burgher forces as a component of Natal's defensive structures that was undermining the volunteer system within the colony. In a letter sent to the Newcastle district magistrate, Captain J.S. Robson of the Buffalo Border Guard

${ }^{102}$ Ibid., 523. 
lamented the internal conflict and tension which seemed to exist between the volunteer system and the local Afrikaner population, at the same time putting forward his of suggestions for improving the current system. Robson, who also acted as the field cornet of Newcastle's No. 2 ward, presented his scheme for increasing recruitment and dealing with the lack of enthusiasm for volunteering among the Afrikaner population. Newcastle, by all accounts, was one of the more remote townships in Natal during the formative period. At the time of Robson's letter in 1873, it had just recently been separated from the Klip River District into its own county for the convenience of the magistracy. The township lay between the Drakensberg range and the upper branches of the Tugela River and was precariously close to the Zululand and Orange Free State Border. There were also a number of Afrikaner farmers in the region, due to the massive amount of land that was available; 600,000 acres of crown land by $1874 .{ }^{103}$ The presence of a large Afrikaner population helps explain Captain Robson statement that "volunteering is not generally in favour up-country."104

This region of Natal was largely devoid of a reliable burgher force, or at least its reliability was somewhat in questions to Captain Robson. Robson pointed out that the vast majority of these Afrikaners had come to the Newcastle region to be as far from British rule as possible, yet "at the same time under British protection."105 Robson's concerns, however, stemmed from the contradictions between public and private statements made by the Afrikaners, where on one hand they promised to be ready, willing, and able in the event of a confrontation, privately they were less enthusiastic. Robson states that in private conversation, the Afrikaner's opinions were strikingly different:

\footnotetext{
${ }^{103}$ Emigration to Natal, and Conditions of Government Land Grants: With Full Description of the Colony and Its Industries (London: Jarrold \& Sons, 1876), 42-44.

104 John J. Robson to Resident Magistrate Osborn, Newcastle, September 4, 1875, CSO 528, No. 2750, 1875. 105 Ibid.
} 
In case of a row you must not think that I shall be fool enough to help you. I shall be off to any place where my stock will be safe. If there is space in the Free State, I go there; if there is space in the Transvaal I go there if the road is open. When the niggers have killed you all, or you have killed the niggers I shall come back to my farm. My land will not run away, but you don't catch me fighting for the English man. He brought the Kafirs here, let him fight them. ${ }^{106}$

This account is Robson's interpretation, yet such language illustrates an undertone of disdain for the British. Robson goes on to describe multiple occasions during the Crimean War, Indian Rebellion, the British Abyssinian expedition of 1868, and the Ashanti Wars in which the Afrikaners would allude to "their time coming", illustrating the continuing hope that British rule would depart or simply collapse. Ironically, this wish for the decline of the British Empire is not at the centre of Robson's concern, but instead the captain laments the lack of respect and appreciation for the defensive institutions that existed within the colony. Robson calls it "unfair" that the Afrikaners were allowed to "shirk the task of defending the Colony, and sit at home at ease" as the units of the mostly British volunteer corps took up the duty of defending the colony. ${ }^{107}$

Robson's proposed solution to the issue was to impose a head-tax on all able bodied men in the district who did not belong to a volunteer corps. This tax would correspond with a small increase in the number of volunteers in the district, as well as an overall increase in the number of days the volunteer units would be able to drill. Interestingly, at this point in the letter Robson's concerns for the Afrikaner population are replaced by an overall concern for the readiness and abilities of the volunteers. The captain argued that the number of days the volunteer should be paid for drilling per annum should be increased from 10 to 20 , largely because in his opinion, "ten days drill in a year will not make a man an efficient soldier". ${ }^{108}$

\footnotetext{
106 Ibid.

107 Ibid.

108 Ibid.
} 
Robson in this instance was indicative of the greater role the volunteers had within colonial society, as well as the perceived place of these volunteers by its members. Robson saw himself as a critical component of the colony of Natal, claiming that he took "the greatest interest in volunteer affairs, and would like to see them go ahead." ${ }^{109}$ Robson even went so far as to dismiss claims by some in the colony that the volunteer corps were becoming less and less important to colonial security with the expansion of the Mounted Police. ${ }^{110} \mathrm{He}$ went so far as to say that the volunteers were the "natural defence of the Colony" and the opponents of the volunteers should be foolish to think otherwise. ${ }^{11}$

Robson's proposal, though initially receiving the support of the resident magistrate, appears not to have gained any ground following its submission to the colonial government. This was almost certainly due to the needs of the colonial government to maintain good relations with the Afrikaner population, and to maintain the status quo in light of increased tension following the Langalibalele revolt and activity in both the Zululand and Free State. Robson did, however, see an increase in the number of volunteers in the Newcastle District with the creation of the Newcastle Mounted Rifles in October of 1875. Ironically, Robson's own unit would lose six troopers over the next year (reducing the force to 24 , barely enough to remain a viable volunteer corps) and the Buffalo Border Guard would cease to exist in 1879 after being nearly wiped out at Isandlwana during the Anglo-Zulu War. ${ }^{12}$ Despite Robson's lack of success, his view still represents an important component of the volunteer mentality that only with a well-trained, well-equipped, and well-disciplined force could the European colonists of Natal defend themselves from outside aggression. The major threat,

\footnotetext{
109 Ibid.

110 The creation and importance of the Natal Mounted Police will be discussed in a later chapter.

${ }^{111}$ John J. Robson to Resident Magistrate Osborn, Newcastle, September 4, 1875, CSO 528, No. $2750,1875$.

${ }^{112}$ For statistical data, see "Military", Natal Blue Books, 1875-1880. For details on the Northern frontier during the Anglo-Zulu War, See John Laband, P. S Thompson, and Sheila Henderson, The Buffalo Border, 1879: The Anglo-Zulu War in Northern Natal (Durban: Dept. of History, University of Natal, 1983).
} 
according to Robson as well as the Afrikaners in his district, was not the Free State to the west, the Transvaal to the north, or even the Zululand to the east, but the indigenous Africans who resided within the colony itself, fuelling the need for white European elements of security.

"One of the People" and Robson are only two examples of alternative methods and solutions to the problems of colonial defence. Another came in a paper on colonial defence written in February 1875, printed in the Natal Mercury, and forwarded to the colonial government that attempted to completely redesign the volunteers and defensive structures of the colony of Natal. The author of this proposed reform was H.E. Stainbank. Stainbank was the manager of the Natal Coffee Works in Umgeni and saw himself as an important member of the Natal community as he viewed "coffee planting [having] always been looked upon as a gentlemanly pursuit."113

Though it remains unclear what was Stainbank's expertise in the area of defence, his concerns were very similar to "One of the People": the presence of the indigenous African population and the readiness of the colony to defend themselves. It was Stainbank who supplied the quote from the Colenso bluebook illustrating the contempt the Africans showed to the drills of the volunteers. Stainbank argues in his account that this contempt was not confined to the Africans: "It is of no use comforting ourselves with the idea that because many Colonists have at some time or other been drilled in the Volunteer Corps, they would be therefore available in an emergency." 114

\footnotetext{
${ }^{113}$ As he stated in his book on coffee planting published as a guide to young planters. See H. E. Stainbank, Coffee in Natal: Its Culture and Preparation (London: Edward Stanford, 1874).

114 "Paper on Colonial Defence, February 1875," Enclosed in H. Stainbank to the Colonial Secretary, April 22, 1878, CSO 639, No. 1426, 1878.
} 
The coffee planter argued that a major reason veteran volunteers did not join new corps (a statement that is not entirely accurate), was because they had learned "the futility of such organization". ${ }^{115}$ To make matters worse, in his opinion the new commanders of the volunteers did not have the same "cross-country" experience as the early commanders of the volunteer corps. ${ }^{116}$ Instead many of the current volunteer corps were not under the command of veterans considered necessary at the time of an emergency, but instead were "under the command of a Durban merchant who [had] scarcely been outside the Borough expect by means of the post card". ${ }^{117}$ The current volunteer officer, according to Stainbank, was little more than a man who wore a sword on parade, or acted as ornamentation at a public ball. Ironically, Stainbank complaints that one of the major failings of the current system was the possibility of volunteers being commanded by regular officers in cases of emergency, making his concerns with the qualities of the officers rather dubious. The root of such problems stemmed from the volunteer system itself, including the drills and officer structures that weakened colonial security and lessened the likelihood of able men taking part in colonial defence because of the time constraints caused by the drill system.

Stainbank's solution to the issue was, not surprisingly, a complete redesigning of the defensive system of the colony of Natal. He understood the merit of a volunteer system and its tradition that stood against the premise of conscription, taking examples from a council member who reportedly said he "did not come to Natal to be made a soldier of" or the phrase "one volunteer is worth twenty pressed men." 118 Nonetheless, quoting Garibaldi that "volunteers cannot be kept up without enthusiasm", Stainbank argued that once volunteers

115 Ibid.

116 This despite the fact that the first commanding officer for the Natal Carbineers was Sir Theophilus John St George, 3rd Baronet of Athlone, and the first commander of the Durban Rangers was Lieutenant-Governor Sir Benjamin Pine.

117 “Paper on Colonial Defence, February 1875," CSO 639, No. 1426, 1878.

${ }^{118}$ Stainbank is likely taking the phrase from Thomas Phipson, or this at least illustrates it was a common idiom in Natal. See Currey, Letters and Other Writings of a Natal Sheriff: Thomas Phipson, 1815-1876. 
were sent into the field, the training they had experienced would be inefficient and the discipline instilled in them would quickly dissipate on anything beyond a short excursion. ${ }^{119}$ Instead, Stainbank argued for the creation of a militia system which would "never require compulsory action except under improbable circumstances." 120 The colony would be divided into districts and officers would be appointed by merit, instead of election, and the unit would be one body instead of a collection of regimental corps. The only somewhat formalized organization would be four man groups called "units of cohesion". These men would preferably be neighbours and would not leave each other's side in the field.

Notwithstanding the impracticality of such a system, the most glaring difficulty in this hypothetical system would be the manner in which the troops were trained. Stainbank argued that it was not necessarily important that a trooper for this hybrid militia-volunteer drill, but simply that he should "know his drill" which would be decided by a six-monthly inspection. If at this point the trooper could not show his efficiency, then he would be forced into compulsory drilling. Major Dartnell, when made aware of this manifesto, commented that "Mr. Stainbank evidently does not understand the subject upon which he writes and I consider his system infinitely more complicated than the one at present in use."121 This could explain why, when presenting his suggestions three years after their publication to the colonial government, Stainbank appears less enthusiastic about his overall plan. He remained "doubtful whether any militia bill would now be passed by the Legislative Council" and went so far as to state "it would be manifestly unjust to do away with the Volunteer Corps altogether". ${ }^{122}$ Stainbank's change in opinion could have been caused by a multitude of

\footnotetext{
${ }^{119}$ Giuseppe Garibaldi use of volunteers in revolutions in Italy, Uruguay, and Argentina, particularly his invasion of Sicily with his 1000 Redshirts, was a staple of the dialogue on nationalist defence for nineteenth century Europeans.

120 "Paper on Colonial Defence, February 1875," CSO 639, No. 1426, 1878.

${ }^{121}$ J. Dartnell, Major, Com. Volunteers to Colonial Secretary, April 26, 1878, CSO 639, No. 1426, 1878.

${ }^{122}$ H. Stainbank to the Colonial Secretary, April 22, 1878, CSO 639, No. 1426, 1878.
} 
factors. The Volunteer Regulation Act of 1877 had come into effect and solidified the volunteer's place within the colony. Tension along the border of both the Zululand and the Transvaal would also cause pause in a complete overhaul of the colonial defence system. Or perhaps time and the personal responses to his opinion in the Mercury had stifled his former enthusiasm. Whatever the reason, Stainbank concluded his later letter that accompanied his piece on colonial defence with a more modest suggestion of creating a reserve "midway between the Volunteers and private people". ${ }^{123}$ This could be taken up by the local rifle association, if the money's received by the association could be replaced with the supply of arms and ammunition annually, similar in vain to the volunteers. Though this suggestion was met with some enthusiasm by Major Dartnell and others, it was dismissed due to the lack of available funds.

Though Stainbank, "One of the People”, and Robson all made suggestions for major changes within the colony, none of their recommendations were every fully implemented. The discourse and debate over the role of the European volunteers, however, illustrate how defence and colonial order remained pivotal disputes in the development of the colony of Natal. In some cases, such as the suggestion of the creation of a commando unit, elements of these debates would shape the creation of a policy, seen with the greater emphasis on cavalry than infantry under the volunteer system. Also, these men were not wrong in many of their assumptions about the volunteer and defensive systems of the colony. Stainbank was almost prescient in his apprehension about the readiness of the volunteers in a prolonged campaign, as would soon become evident after the outbreak of the Anglo-Zulu War. The problems of desertion, inability to stay in service, the draw of remaining on the home front, and simple homesickness all stem for the problems with the volunteer system cited by Stainbank. Whereas these solutions to the problems of Natal's defence were impractical, unreasonable,

${ }^{123}$ Ibid. 
or costly, these editorials illustrate at least a small element of the public debate about colonial security that remained on the minds of the colonist and their government throughout this formative period.

\section{Frustrations with the System}

Tangible reform did, however, take place at the same time as many of these calls for action from the colonial population. Perhaps most importantly, the Volunteer Law of 1872 made a strong attempt in creating a more formalized volunteer force which could better fulfil its duties within the colony. The law "For the Better Regulation of the Volunteers in the Colony of Natal" was intended to replace the old volunteer law of the 1850 s and provide a more refined defining to how units would be organized and run. ${ }^{124}$ More importantly, existing corps were given a 60 day grace period to resubmit their bylaws in the new law, and those which did not were no longer considered active. Considerably more power was given to the inspector and commandant of the volunteers, and greater detail was provided for the responsibilities which fell under said offices. Though both were occupied at the time by Commandant Giles, the predecessor of Dartnell.

The importance of the shift in government involvement after the Volunteer Law of 1872 cannot be minimized. The new advantages and rights granted to the volunteer while on duty illustrate not only their growing perceived importance to the defensive structures of the colony of Natal, but also the formalization of the governmental systems within this ever evolving colonial state. The language of the law illustrated a shift toward a more government regulated military system that relied heavily on a more formalized system of control that moved from the lieutenant-governor to the commandant and inspector of the volunteer forces, and eventual to the local commanders that were granted approval to form units by the

124 "Law No. 15, 1872, For the Better Regulation of the Volunteers in the Colony of Natal," The Natal Government Gazette, December 10, 1872. 
lieutenant-governor. This change in the command structure was strikingly different from the original Volunteer Law of 1854 . The chain of command and the manner in which orders would be transmitted throughout the volunteer system was given much greater detail and attention within this law. Though an inspector of the volunteers, typically under the rank of captain, had been part of the system since 1865 , his authority within the volunteer system had not been clearly outlined by law. ${ }^{125}$ The new position of commandant would be appointed by the lieutenant-governor and whose eligibility for office rested on having "served not less than six years as a commissioned officer in Her Majesty’s regular army."126

The chief responsibility of the inspector and commandant was not only to act as the representative of the lieutenant-governor and commander-in-chief, but also to manage the arms and equipment of all volunteers. As has been noted, a major disadvantage of the early volunteers was a lack of supplies, weaponry, and serviceable gear. Instead of commanding officers simply sent reports to the office of the lieutenant-governor, the inspector would biannually visit the headquarters of all the corps to examine arms, ammunition, and stores to insure that they were in a proper military state. What made this system even more effective, in theory, was the authority of the inspector and commandant to have unlimited access to these stores for inspection, in essence providing a nearly free hand by the government to these civilian institutions. In return for this greater oversight, the Natal government would become responsible for the distribution of arms to the corps, specifically breech-loading rifles, "to be supplied by the Government on receipt of a bond for its safe custody and

\footnotetext{
${ }^{125}$ L. J. Rolleston held the position from 1865 to 1872 , where he was paid $£ 200$ annually for his position. Because volunteer groups were required to report of the lieutenant-governor, it would be logical that Rolleston's role in the colony rested largely as an intermediary between the Executive office and the commanders of the volunteers. The Natal Almanac and Yearly Register (Pietermaritzburg [S. Africa]: P. Davis, 1867), 196.

${ }^{126}$ Cadiz, Natal Ordinances, Laws, and Proclamations, 906. The first Major-Commandant of the Volunteers was James Giles, formerly of the $14^{\text {th }}$ Hussars and a Justice of the Peace for Weenen County. "Establishments", Natal Blue Books, 1872.
} 
return." ${ }^{127}$ The volunteers would also receive field equipment, pack-saddles, picket poles, ropes, and other the materials necessary for it to move out on short notice if actual service was necessary. Such formalized supply systems was a major break from the self-sufficient and undersupplied parameters of the 1850s and 1860s, but not without cost to the original spirit of the volunteers.

One of the more substantial changes in the makeup and organization of the volunteers under the 1872 law rested on the individual agency and authority volunteers maintained within their own units. The selection of officers was now initiated and approved by the lieutenant-governor, though names would not be submitted without the approval of at least one half of the members of the corps. The names submitted, however, would first be forced to pass "a satisfactory examination as to his proficiency in drill before a board of officers to be appointed by the Commander-in-chief, of which the Inspector shall be president."128 To make matters even less democratic, non-commissioned officers were no longer elected by the corps but were instead appointed by the officers of those corps. The reasons behind these changes are self-evident: the flaws within the volunteer system during the 1850 s and 1860 s stemmed extensively from a lack of discipline and military precision within the volunteer corps. Such changes also indicate a growing concern for the necessities of such security to be raised up to the same level of the ever evolving colonial state. In essence, Natal's government did not need such formality during its early years, simply because of the lack of both population and members of government. The colony had not yet received its charter in 1854, but by 1872 had established itself as a viable component of the British Empire. This is even more evident in

${ }^{127}$ Cadiz, "Law for the better regulating of the Volunteer Force in the Colony of Natal, Law No. 15, 1872", Natal Ordinances, Laws, and Proclamations, 906.

${ }^{128}$ Rule 18 illustrates again this greater formalization of language when compared to Rule 4 of the 1854 law, including such phrases as "under the Public Seal of the Colony...shall allow their names to be submitted" versus the more simplistic "subject to the approval of the Lieutenant-Governor". "Cadiz, "Law for the better regulating of the Volunteer Force in the Colony of Natal, Law No. 15, 1872", Natal Ordinances, Laws, and Proclamations, 907. 
the inclusion of an oath of allegiance that would follow an individual's enrolment in the corps, issued before a Justice of the Peace, or commissioned officer of the corps:

I, A.B. [stand in for the name], do sincerely promise and swear, that I will be faithful and bear true allegiance to Her Majesty Queen Victoria, Her Heirs and Successors, and I will faithfully serve in the Volunteer force until I shall lawfully cease to be a member thereof. ${ }^{129}$

As a sworn member of the volunteer corps, this social club environment became more and more a military institution within the colony of Natal.

This greater formalization also resulted in more stringent discipline. When pressed into actual military service, the volunteers would fall under the statutes of the Mutiny Act, in essence making them "entitle[d] to the benefits thereof in all respects as the officers and soldiers of Her Majesty's army for the time being" and forcing them to fall within the greatly restrictive systems of the Imperial government. ${ }^{130}$ Such matters on the role of discipline and how the volunteers would fit within the Mutiny Act would be a major issue during the AngloZulu War (see below).

Discipline, even before the Anglo-Zulu War, remained the key hallmark to this new law, insuring greater discipline for both the officers and troops under the system. Though, in keeping with the volunteer tradition, harsh discipline would only "take effect and be in force when [the volunteer corps] are on actual military service". ${ }^{131}$ Despite this extension of the volunteer laws, there remained a disparity between the law and the implementation of said

${ }^{129}$ Such an oath is nearly identical to that which would be required to join the British Army. The issue of oaths, and their power within the colonial world is an idea that has only been briefly examines by some historians, but could illustrate deeper connections to loyalty within the British Empire. See Miles Ogborn, "The Power of Speech: Orality, Oaths and Evidence in the British Atlantic World, 1650-1800," Transactions of the Institute of British Geographers 36, no. 1 (January 1, 2011): 109-25.

${ }^{130}$ Though capable of being tried for court martial, no volunteer was liable to corporal punishment, a major benefit compared to Her Majesty's troops. Cadiz,"Law for the better regulating of the Volunteer Force in the Colony of Natal, Law No. 15, 1872", Natal Ordinances, Laws, and Proclamations, 912.

${ }^{131}$ Ibid., 912. 
law. Though it remained the responsibility of the inspector to "superintend the drill, discipline, and organization of the several corps" and to "make at least two visits of section each year to the Headquarters of all the corps", if the corps could and would not muster, it made such responsibilities impossible. ${ }^{132}$ This became the source of considerable frustration for the commanders of the volunteers over the ensuing years.

A striking example of the overall lack of discipline and organization by the early 1870s can be found in the yearly report of Commandant Giles in 1873. In the report, Giles makes numerous attempts to illustrate the progression of the volunteer corps and their overall growth, especially in the number of units being formed. The attempt to organize the yearly drill at two camps, one at Uys Doorns (outside Pietermaritzburg) and the other at Estcourt, by the commandant demonstrates the extreme disorganization and lack of military precision that existed. ${ }^{133}$ The Natal Carbineers lacked a commanding officer and the Maritzburg Rifles commander stated that "in consequence of nearly all of his men being employed in stores in the town, he could not bring more than 18 to camp" (with the official muster size being 105). ${ }^{134}$ To make matters worse, the commander of the Victoria Mounted Rifles wrote: "The sugar planting was then just coming on, and to attempt to force the corps to march to Uys Doorns would result in breaking it up altogether."135 The only way these men could be mustered was if they received service pay for the drill; a request summarily rejected by the lieutenant-governor. ${ }^{136}$ So bad was this attempted muster that Giles was forced to cancel the camp for the year. His recommended solution to the problem rested on the increase in travel expenses for the corps, from $£ 10$ to 15 per year, but the ten day camp period would need to

\footnotetext{
${ }^{132}$ Ibid., 912.

${ }^{133}$ Legislative Council, Natal, Document No. 31, "Report of Commandant of Volunteer Force for 1873, November 12, 1873," NCP 4/1/1/3, 1873-1874.

${ }^{134}$ Ibid.

${ }^{135}$ Ibid.

${ }^{136}$ Ibid.
} 
be increased to sixteen days. Though the camp at Estcourt was more successful, with only one corps out of five failing to muster, the event illustrated how service in the volunteer corps was not always the primary concern of the citizens who took part in them.

The following year, the newly appointment commandant, Major Dartnell, did little better. Dartnell again attempted to hold the annual camp at two locations, Camperdown for the Coastal and Midland corps and Estcourt for the Up-country corps. Once again, the coastal and midland meeting was a complete failure. The coast corps "had suffered so severely from horse sickness at the commencement of the year that nearly half were dismounted...the Ixopo Mounted Rifles were without arms, and the Richmond Corps were almost defunct [having dropped below twenty members]." 137 The camp at Estcourt also failed, but largely due to the expense of travel and the lack of arms. Others, including the Weenen Yeomanry Corps, were unwilling to turn out due to recent incidents (assumedly the Langalibalele revolt), fearing they would "leave their farms unprotected." 138 Again, the overwhelming concern for most of the volunteers rested on events at home and not within the corps.

Dartnell's frustration was evident in his report, but he also expressed a practical understanding of the situation. Though he understood the purpose of Major Giles recommendations from the previous year, he saw them as entirely impractical: "I doubt very much if yearly Camp meetings will ever become popular amongst the Volunteers generally, for no matter whether it be a Coast, Town, or Upcountry Corps, the majority of the members cannot afford to give up sixteen consecutive days to attend a Camp of exercise."139 Dartnell argued instead that the "esprit de corps" that these camps hoped to establish were "not absolutely necessary for the work Volunteers would be called upon to perform in case of an

\footnotetext{
${ }^{137}$ Legislative Council, Natal, Document No. 112, 1874. "Report of Commandant of Volunteers on the Volunteer Forces of the Colony, November 19, 1874," NCP 4/1/1/3, 1874.

${ }^{138}$ Ibid.

${ }^{139}$ Ibid.
} 
outbreak in the Colony."140 Darntnell was largely acting under the assumption that the volunteers would serve as a home defence force that could be used is a limited formal military capacity and less as a commando unit that many aspired it to be. ${ }^{141}$ Dartnell instead suggests that attendance to the camps be left optional, and volunteers who attend would receive the extra pay for their attendance. This is because, to Dartnell, the yearly camps that required volunteers to arrive and perform their duties in a military fashion over ten days went against the spirit of the volunteers:

If attendance at yearly Camps of exercise is made compulsory, and the men are placed under the Mutiny Act [working under strict military guidelines] during the time they are in Camp, they would be no longer Volunteers except in name, but would be, to all intents and purposes, Militia, in which case every able-bodied man in the Colony should be obliged to join the force, or contribute directly to its support. ${ }^{142}$

Though it remains unclear in his report if Dartnell was seriously suggesting the formation of a conscript system, he did successfully summarize the spirit of the volunteers: a group of men who are not forced to join, but choose to join an organization focused on the collective defence of the colony. Lapses in training and discipline were an intricate part of this type of system.

\section{Defence Commission of 1875}

The frustration with the volunteer system from its commanders, combined with the Langalibalele Incident of 1873 (which will be discussed later), caused a greater demand for changes in the volunteer organization by the mid-1870s. Not surprisingly, the volunteers were one of the central topics for the Defence Commission of 1875 . The commission attempted to

\footnotetext{
${ }^{140}$ Ibid.

${ }^{141}$ Dartnell presumably envisioned this role falling upon the Natal Mounted Police that would be formed the following year which will be discussed in Chapter Four: European Police.

${ }^{142}$ Legislative Council, Natal, Document No. 112, 1874. "Report of Commandant of Volunteers on the Volunteer Forces of the Colony, November 19, 1874,” NCP 4/1/1/3, 1874.
} 
address whether to completely reorganize the volunteer system, or alter the existing structures. It concluded that several alterations would not only improve the defence of the colony, but also make the force itself more efficient. Questions remained as to the efficiency and outright need for an increase in the volunteer force, especially in light of the establishment of a European mounted police force, known simply as the Natal Mounted Police, in $1875 .{ }^{143}$ The commission outright dismissed in its report the possibility of increasing the number of troops, stating that 1,000 cavalry and 400 infantry and artillery were as much as the colony could supply, considering Natal's "small and wisely scattered population, and the necessity of providing for the defence of those left at home."144 This idea was largely contradictory to the actual situation in the colony, in which there were nowhere near as many troops active under the volunteer system. ${ }^{145}$ Such expectations show optimism for the numbers available, yet the commission also recommended that infantry corps only be established in large towns or centres of population, largely because "small isolated bodies of infantry do not add proportionally to the strength of the available field force."146 These conclusion were undoubtedly a response to the failures to muster both commandants reported in 1873 and 1874 . The commission also recommended in certain cases the lieutenantgovernor have the power to limit the numbers of infantry or cavalry corps from 100 or 60 to 150 or 85 , respectively. Such changes would, in the words of the commission, "avoid unnecessary multiplication of independent corps." 147 These suggested were actually

\footnotetext{
143 The establishment, organization, and importance of the Natal Mounted Police will be discussed in Chapter Four: European Police.

${ }^{144}$ Minute Paper: Volunteer Forces- Recommendation of the Defence Commission of 1875 regarding the same, CSO 591, No. 1557, 1877.

145616 in 1874, 730 in 1875, 627 in 1876, 644 in 1877, and 760 in 1878. See "Military", Natal Blue Books, 1874-1878.

${ }^{146}$ Minute Paper: Volunteer Forces- Recommendation of the Defence Commission of 1875 regarding the same, CSO 591, No. 1557, 1877.

${ }^{147}$ Ibid.
} 
implemented by the lieutenant-governor the following year. ${ }^{148}$ Again, these reforms centred on an attempt to consolidate and perhaps make more efficient the volunteer system of the colony. ${ }^{149}$

Another central concern for the commission was the overall lack of multiple volunteer artillery units. One unit, the Durban Volunteer Artillery, had been in existence since 1870 and typically numbered around 45 men. The commission, however, questioned whether this was sufficient for inland areas of the colony, particularly Pietermaritzburg (largely ignoring the presence of Fort Napier). Perhaps a more important component of this need for artillery was its purpose. The commission did not envision large calibre artillery like that which defended Port Natal in Durban, but instead saw the necessity for "the lightest pattern of Mountain Guns, such as was used in Abyssinia and Ashanti and with portable carriages and pack equipment and further that each battery be provided with rocket equipment.”150

This request is particularly telling. The defence commission was obviously aware of the war with the Asante in 1874 and the invasions of Ethiopia in 1867-68. The use of artillery in these campaigns clearly had a major impact on the members of this commission, to the extent that it was one of the first points made by the commission for improvement of the volunteers as a whole. More importantly, however, it's the acknowledgment of other British forms of military defence within a colonial system that the leaders of Natal were attempting in some ways to emulate. The additional artillery corps was never formed before the Anglo-

\footnotetext{
148 This could largely explain the lack of new corps being established between 1875 and 1879 . Even in the case were new corps were established, they were always cavalry and rarely met the establishment number of 85 .

${ }^{149}$ This same period saw a large push for reform within the Natal colonial government, as is evident in a multitude of constitutional amendments that altered the election districts from the original colonial charter and increased the number of unelected members in the Legislative Council. Such changes are donative of a call for change related to colonial system, including defence. For amendments and charters, See G.W. Eybers, Select Constitutional Documents Illustrating South African History, 1795-1910 (London: George Routledge \& Sons, 1918), 190-200.

${ }^{150}$ Minute Paper: Volunteer Forces- Recommendation of the Defence Commission of 1875 regarding the same, CSO 591, No. 1557, 1877.
} 
Zulu War, and the suggestion was outright dismissed by the Lieutenant-Governor Bulwer, claiming "so long as there was a force of Royal Artillery in the Colony no new local artillery corps ought to be raised." ${ }^{151}$ The cost was simply impractical in relation to the need. ${ }^{152}$

The commission also made numerous attempts to alter the command structure and organization of the volunteers in conjunction with the newly establish mounted police force. A major point of contention rested on the positions of commandant and inspector of the volunteers and the nearly created commandant of police. By 1875 , both of these positions were held by Major J.G. Dartnell, who had acted as commandant since his arrival in 1873. The commission, which Dartnell was a part of, recommended that the position be taken up by two individuals. In the committee's opinion, these two positions could not be successfully done by one man, with the union of the two positions being seen as "a temporary and tentative measure". ${ }^{153}$ With the increase in the police force, such a tentative situation would only grow worse, in the opinion of the committee. This was presented as more dire by the committee due to the likelihood that if an incident occurred within the colony, Major Dartnell would in all likelihood be the first to respond with his mounted police force, as this was the primary reason the unit was established. The committee feared that this would leave the volunteers and the lieutenant-governor without their commandant and the military advice he would be able to provide in an emergency. Though a reasonable observation, the recommendation was categorically denied, and Major Dartnell would retain his duel position for the next decade.

151 Ibid.

152 Many of these suggestions had been made my Commandant Giles in his 1873 yearly report, but few major changes seemed to have taken effect by 1875. Legislative Council, Natal, Document No. 31, "Report of Commandant of Volunteer Force for 1873, November 12, 1873," NCP 4/1/1/3, 1873-1874.

153 Ibid. 
A major exegesis for this decision could simply have been cost. Dartnell received $£ 450$ annually for his position as commandant of the mounted police, but he also received $£ 150$ for his work as commandant and inspector of the volunteers. Comparatively, Major J. Giles, the previous inspector, only received $£ 300$ in 1873 as commandant and inspector of the volunteer corps. ${ }^{154}$ If another individual would have taken over the position, it would have been assumed he would receive at least the same salary as Giles. Though small, a savings of $£ 150$ could have been reason enough to avoid a new appointment. The commission instead recommended the complete elimination of the position of commandant of the volunteers, recommending that the duties of the inspector be performed by a member of the military garrison at Fort Napier. In essence, the officer from the garrison would act as an adjutant to the lieutenant-governor, who was officially in command of the volunteers. By removing the position of commandant, the commission believed that the officer acting as the inspector (or a rank no higher than captain) would receive a small allowance for his additional duties, presumably around the $£ 150$ Dartnell received as commandant and inspector of the volunteers. Despite these recommendation for the highest ranking officer of the volunteers, perhaps the most significant suggestion regarding the officer corps came in the form of how the volunteer officers and non-commissioned officers would receive qualified training. The commission suggested that those "wishing to qualify themselves by a course of instruction should be permitted to join the Regiment or Battery in Garrison for the purpose", in essence bringing the officers into the fold of the formalized British military from a training perspective and in theory instilling the same level of discipline and training into the volunteer corps. ${ }^{155}$ This once again illustrates the overriding view that the volunteers, to become more

\footnotetext{
154 “Expenditures”, Natal Blue Books, 1870-1875.

${ }^{155}$ Minute Paper: Volunteer Forces- Recommendation of the Defence Commission of 1875 regarding the same, CSO 591, No. 1557, 1877.
} 
effective as a military force, would form themselves less as a social club and more as an official military unit in the structure of colonial defence.

Though the vast majority of the suggestions made by the commission were either ignored or never fully implemented, they illustrate the calls for reform that characterized the period between the build-up to the Anglo-Zulu War and the post Langalibalele era. The suggestions of increase in volunteer compensation and the willingness for the lieutenantgovernor to consider, though not fully implemented such suggestions, still illustrates the importance of defence within the mind-set of the colonial government. Natal was moving toward a more formalized form of defence that not only fell in line with a more traditional British military system, but also increased the expectations for its members as a military force. The balance between civilian life and the leisure activities of the volunteers was quickly coming to an end, especially as war with the Zulu kingdom could be seen on the horizon.

\section{The Indian "Volunteer" Corps}

A largely ignored component of the population (outside of the Africans who worked as a crucial element of colonial security) was the Indian migrant population that became a prominent force in the colony following the import of Indian indentured labour in 1860. In 1875 , the legislative council approved a bill that would allow for the creation of an Indian Volunteer Corps within the colony. The bill (and eventual law in 1875) amended the Volunteer Law of 1872 and 1873, increasing the maximum number of troops by 1,700, with "the proportion of Indian Immigrant Volunteer Infantry [being]...one thousand three hundred." 156 "Volunteer" does not fully illustrate the involvement of the Indian migrants in this newly created defensive structure. The vast majority of Indian labour in the colony was

${ }^{156}$ Bill: To Amend the Volunteer Law, 1872 and 1873, GH 1022, No. 22, 1875. 
focused on the sugar industry and the construction of the Natal railway system. In light of this, the bill stipulated that the volunteer force would be formed into corps "provided that the Indian Immigrants employed in the Civil Engineer's Department shall be divided into so many separate Corps, and consist of such number of Volunteers as the Civil Engineer may from time to time appoint." 157 The use of the term "appoint" is a linguistic deviation from the original message of the earlier volunteer laws. This becomes even more striking when the bill stipulated that "any planter who can raise such a corps of Indian Immigrants as aforesaid shall be, on the approval of the Lieutenant-Governor, appointed Captain of the same, and shall appoint his subaltern officers, subject to the approval of the Lieutenant-Governor."158 Because planters possessed so much power within the colony, especially over their Indian labour force, such a stipulation illustrates the supreme possibility that planters could force their workers to join these corps, and immediately act as both their military and civil commanders.

To make matters worse, the democratic elements of the volunteer laws were largely removed or did not apply to the Indian "volunteers". While officers in the white volunteer corps would typically need the approval of "not less than one-half of the enrolled members of any such Corps", this element of Section 18 of the Volunteer Law of 1872 was not applicable to the Indian volunteers. ${ }^{159}$ Captains were to receive the entirety of the corps grants from the government, and it was his responsibility to distribute funds for drills and other payments. This system of payment was not a striking deviation from the traditional volunteer system, yet the Indian volunteers would receive around half the pay for their service (one shilling six pence versus three shillings for white volunteers) while officers would continue to be paid the standard amount. To make matters worse, the Indians were not trusted with the firearms they

157 Ibid.

158 Ibid.

159 Ibid.. 
were provided by the colonial government as arms when "not in actual use shall be returned in safe keeping by persons to be appointed by the Lieutenant-Governor."160 Even the bond which would be granted to the volunteer for the safe return of his rifle was never provided to him, but instead was exclusively handled by the commanding officer.

Perhaps the most jarring deviation of the Indian Volunteer Law from the volunteer law was the treatment of the volunteer in the event of his death or injury while in service. Under the Volunteer Law of 1872, the widows and children of those engaged in "actual military service" would be entitled to compensation, "in the case of a widow such compensation shall not be less than a gratuity of Three hundred pounds" and if wounded or seriously injured, would receive compensation "according to the scale of compensation for the time being in force in the regular army of Great Britain." 161 For the Indian Volunteer, no such amount is stipulated for those being killed in action, but instead the executive council would "award such a rate of pension or such a gratuity as the circumstances of each particular case shall require." 162 By implication this meant the colonial government did not see it as suitable to guarantee $£ 300$ for the life of a dead volunteer if he was Indian.

There is no evidence that any Indian Immigration Volunteer Corps was ever formed as there is no trace in the colonial records or other expense reports the decade after its creation. The law, however, is still quite telling about the relationship between the needs for a defensive force, and the inherent racial undertones of the colonial system. Such instances would become even more glaringly obvious with further examination of the role of indigenous Africans in colonial defence. ${ }^{163}$ The Indian population by the 1870 s was becoming a critical component of Natal's economy, and the inclusion of them in the networks

\footnotetext{
${ }^{160}$ Ibid.

${ }^{161}$ Cadiz, Natal Ordinances, Laws, and Proclamations, 910.

${ }^{162}$ Ibid., 910.

${ }^{163}$ See Chapter Five and Six.
} 
of colonial defence was a foreseeable conclusion. Yet there still remained a supreme apprehension in providing too much autonomy to these Indian forces. The Indian Rebellion of 1857 and its enduring memory in the 1850 s and 1860s had caused an important shift in the racial perceptions and debates over race within the British Empire. ${ }^{164}$ Such debates over the place of Indians in the military would continue throughout the nineteenth century, though the response from Africans to the idea of Indian troops within the colony will be discussed in a later chapter. Ironically, one of the few longstanding impacts of this "Indian Volunteer" Law was its use by Gandhi in 1905 and 1906 as a pretext to for allowing the creation of an Indian volunteer corps in response to the Bambatha Rebellion. ${ }^{165}$ The law does represent a clear understanding of the needs of defence in Natal, while still taking into account the strikingly racialized attitudes of the colonial government. It was these same racial attitudes that would influence the response to one of Natal's most infamous incidents during its formative period: the Langalibalele Incident.

\section{The Langalibalele Incident}

Over the ensuing decades, the growth of the volunteer corps would continue within the colony of Natal. The volunteers would not be part of a major military incident during this period, the era could be characterised by relative peace. ${ }^{166}$ By 1873 , the volunteer corps numbered 20 cavalry and four infantry corps, with a total of 819 men. Then, Natal experienced perhaps one of the volunteers most famous, and most commemorated, event in the history of the volunteer corps: the Langalibalele "Rebellion" or Incident of 1873. Put

\footnotetext{
${ }^{164}$ Race, or at least the view of race from the context of nineteenth century Victorians, remained an anthropological view of the other which combined British misconceptions about race with the unfamiliarity of colonized people. See Christine Bolt, Victorian Attitudes to Race. (London: Routledge and K. Paul, 1971), 4-5.

${ }^{165}$ Gandhi argued that the precedence already existed with the 1875 law, and encouraged Indians to fight against the Zulu. "Indian Volunteering," Indian Opinion, December 2, 1905. Ironically, the Bambatha Rebellion of 1906 is one of the most striking instances of Volunteer atrocities in their existence. See Guy, Remembering the Rebellion.

166 See Chapter One: Introduction for Shepstone's claim of that early Natal experienced "Forty-six years of existence, and forty-six years of peace".
} 
simply, the incident centred on the actions taken by Langalibalele, Chief of the Hlubi over the issue of firearms procession. John Macfarlane, resident magistrate at Estcourt, demanded in 1873 that Langalibalele, a powerful chief between the Bushman's and Little Thukela Rivers, turn in all unregistered firearms under Natal's gun laws. However, the grievous action was Langalibalele's refusal to appear before Theophilus Shepstone. Ironically, Langalibalele had on multiple occasions aided the British in organizing and subjugating other African leaders under the Shepstone system. ${ }^{167}$ In light of this confrontation, Langalibalele, along with a number of his followers, fled to Basutoland. ${ }^{168}$ At this point, the volunteer corps of Natal came into prominence as they marched on Bushman's River Pass.

The history of the Langalibalele Rebellion has been thoroughly examined within the Natal historiography, but a few basic facts about the Bushman's Incident in November 1873 are critical to understanding its importance to the volunteer corps. A number of volunteer regiments were called up in response to Langalibalele's refusal, including the Natal Carbineers. The plan of action included two columns which would move into the Bushman's River Pass in an attempt to prevent Langalibalele from fleeing the colony. Yet the columns did not successfully meet up due to military blunder, leaving a section of the Natal Carbineers under the command of Major Durnford to discover a contingent of Hlubi at the Pass on the morning of November $4^{\text {th }}$. A short engagement broke out, and outnumbered, the Carbineers were forced to retreat. When the dust had settled, three volunteers were dead, along with two indigenous interpreters reporting to Shepstone, and Langalibalele fled toward Lesotho. He was eventually captured on December $11^{\text {th }}$ and was paraded through Pietermaritzburg. The death of the volunteers and his refusal to fall under British administrative rule eventually

${ }^{167}$ See previous chapter for an explanation of the "Shepstone System". The use of indigenous forces to assist colonial authority will be examined in Chapter Six, as Langalibalele is just one example of a complex system of collaboration that existed within the colony of Natal.

${ }^{168}$ For a more detailed analysis of the motives behind Langalibalele's motives, See Norman Etherington, "Why Langalibalele Ran Away," Journal of Natal and Zulu History 1 (1978): 10-30. 
acted as the catalyst for Langalibalele's trial conviction for 'treason' and banishment to Robben Island in Cape Town. He was ultimately permitted to return to Natal, where he died in $1889 .{ }^{169}$

The memory of Langalibalele would have a prominent impact on the history of the volunteer systems in Natal. Not only would the failures of the volunteers lead to greater concerns over discipline during the remainder of the 1870 s, they would also be whitewashed in the history of the volunteer corps. Blame would be ostensibly shifted to the African troops under Captain Allison who failed to arrive on time. ${ }^{170}$ Accounts of the incident are filled with allusions to the defence and valour of the Carbineers. ${ }^{171}$ Little overall criticism of the troops under the command of Major Durnford was evident. The most widely circulated account of the incident was written by Charles Barter, member of the legislative council and commander of the Karkoof Troop who accompanied the contingent of Carbineers at Bushman's Pass. Barter's account does reveal the lack of discipline and inexperience that many members of the volunteers possessed during this conflict that would repeat itself years later during the Anglo-Zulu War. Barter acknowledged that even the "oldest and steadiest" of the volunteers on being surrounded saw that they were possibly trapped and began to panic. ${ }^{172}$ Matters deteriorated more when Barter claimed that Sergeant Clark "loudly shouted that we were going to be murdered". ${ }^{173}$ Panic was presumably exacerbated by Clark's experience fighting Africans in the regular British Army during the Xhosa Wars and his experience in the Cape

\footnotetext{
${ }^{169}$ For a more detailed account of the incident see Bill Guest "Colonists, confederation, and constitutional change" in Duminy and Guest, Natal and Zululand from Earliest Times to 1910, 146-169; and Jeff Guy, Theophilus Shepstone and the Forging of Natal: African Autonomy and Settler Colonialism in the Making of Traditional Authority (Scottsville, South Africa: University of KwaZulu-Natal Press, 2013), 388-399.

170 This will be discussed in further detail in Chapter Six on African military units.

${ }^{171}$ One of the more complete, if not dated, collection of account can be found in R. O Pearse et al., eds., Langalibalele and the Natal Carbineers: The Story of the Langalibalele Rebellion, 1873 (Ladysmith: Ladysmith Historical Society, 1973).

172 Times of Natal, November 8, 1873.

173 Ibid.
} 
Mounted Rifles. It should be noted, however, that Sergeant Clark would defend himself vehemently in the press after Barter's accusations surfaced. Clark claimed that Durnford's order to extend the troops across the extended front of the Pass to show the forces strength was "a fatal error on the part of our commander [Durnford]" as such actions revealed the volunteers were outnumbered and gave confidence to the Hlubi troops. ${ }^{174}$ Though Clark claimed not to remember shouting the troops would be murdered, he did note that Barter would have known that such talk was "in the ranks for more than an hour" and that if he did say such things, it was "to bring our stubborn commander to his senses." 175

The discrepancies between Clark's and Barter's accounts is revealing of the state of confusion which dominated the incident. In Durnford's report to the lieutenant-governor, he claimed that he was informed by the senior officer (Barter) that "the Carbineers, many of whom were very young men, could not be depended upon" saying "they were surrounded, and would be massacred."176 Durnford also laid the blame for the panic on "their drill instructor, an old soldier of the late Cape Corps [likely Clark], up whom they naturally looked." ${ }^{177}$ Both Durnford and Barter were confident that if they had arrived at the Pass before the Hlubi, they would have been able to defend themselves, but the ill timing remained the key failing, not the conduct of the volunteers. Fault, at least for the likes of Barter, did not rest on Durnford, calling the major "as gallant and determined a man as ever breathed, [who] would have cheerfully sacrificed not only us, but himself, in the execution of his order."178

Like Clark, there were others who called into question Durnford's actions. His abilities as an officer and his strength as a commander were incompatible with the mentalities

\footnotetext{
174 The Natal Witness, November 14, 1873.

175 The Natal Witness, November 14, 1873.

${ }^{176}$ BPP: Cd 1025, Papers Related to the Late Kafir Outbreak in Natal, 1874. Memorandum from Major Durnford, Enclosed in No. 11, Lieutenant-Governor B. Pine to the Earl of Kimberly, November 13, 1873.

177 Ibid.

${ }^{178}$ Times of Natal, November 8, 1873.
} 
of the volunteers. The special status of the volunteers was again emphasised by some of the troops. One anonymous writer even claimed that Durnford treated the volunteers as "if we were niggers—not volunteers."179

Guy argues that such attacks against Durnford were a defence mechanism by the volunteers in an attempt to save face, evident in the controversy over the orders not to fire first. ${ }^{180}$ If this was the case, it is odd how the memory of Durnford is so positively preserved in the accounts of Barter, a volunteer and respected member of the community. Durnford was an outsider, who was the son of a general, and brother to a colonel in the British Army, who brought to Natal "that confidence, that conviction of class superiority that many settlers left home to escape."181 Twenty years after the affair at Bushman's Pass, Barter wrote in his "Stray Memories":

Durnford was there, the Engineer;

A man to those he trusted dear:

As eagle bold, with haughty crest,

Yet with deep feeling, though represt;

Cool and contemptuous in tone,

No counsel pleased him but his own:

Proud of his flag, a soldier born,

He held the Volunteers in scorn. ${ }^{182}$

179 The Natal Witness, November 11, 1873.

${ }^{180}$ See Chapter Six: African Military Units.

${ }^{181}$ Guy, Theophilus Shepstone and the Forging of Natal, 392.

${ }^{182}$ Quoted in The Natal Carbineers: The History of the Regiment from Its Foundation, 15th January 1855 to 30th June 1911 (Pietermaritzburg: P. Davis, 1912), 73. 
Whether Durnford was deserving of such contempt, or whether he was truly as ill prepared as a commander as it appears, is not as relevant as the memory it created in the minds of the volunteers. Of course, it should also be remembered that this was the same Major Durnford who many blamed for the disaster as Isandlwana during the Anglo-Zulu War. Military disaster, it seems, was a common theme for the much of Durnford's military career. ${ }^{183}$

This attempt at deflection from the volunteers for the failure in the Langalibalele Incident shows how it remained such a defining moment for the volunteers' organizations within the colony of Natal during its formative period. Like so many of the shortcomings of the volunteer system, fault was attributed to other incidents or individuals, and not the volunteers. The men who died at Bushman's Pass were victims of a military blunder, but their perceived sacrifice was hailed as a testament to colonial power. This is particularly telling in the official history of the Natal Carbineers, which outlined the dispute between Durnford and the regiment, but concludes that all disagreements "were silenced fore ever" five years later when "by the streak of Fortune, the same commander, and two-and twenty of the same Regiment [the Carbineers], who had carried bitter thoughts of one another in their treat from the Bushman's Pass, had fallen together...on the field of Isandhlwana [sic]." ${ }^{184}$ It is almost fitting then that the monument to the Anglo-Zulu War in the shadow of Pietermaritzburg's City Hall stands across the street from the monument dedicated to those that died at Bushman's Pass, a stone monument in Carbineer Gardens, linking these two events in the formative period of the colony of Natal. It remains important to emphasise that both incidents revolved around the failure of the volunteers to act as proper soldiers, and to maintain the discipline that was expected in such a web of defensive structures.

\footnotetext{
${ }^{183}$ This was also a point of contention, as Bishop Colenso's daughter would continue to try and clear Durnford's name for much of her later life, See Guy, The View Across the River.

${ }^{184}$ The Natal Carbineers, 74.
} 


\section{Discipline and the Anglo-Zulu War}

Discipline and training were important elements of the volunteer system, which continued to be emphasized during this formative period. It was emphasized for the vast majority of volunteers, yet membership in the corps was only a small component of their everyday lives. With troops expected to only take part in drill for ten to twenty days a year, and the number of incidences in which they would be called up few and far between, these volunteer organizations were a step above social clubs. In some cases, membership in the volunteer corps would distract from other responsibilities within the colony, much to the irritation of other colonial officials. This became even more evident within Natal's colonial society during the build-up to the Anglo-Zulu War. These instances of lapses in discipline and the complex response to actual military action reveals in the broadest fashion the true impressions of the volunteer corps and their place within the colonial defensive institutions of Natal.

Of course, as has been shown, problems with discipline were not unheard of within the volunteer corps before the Anglo-Zulu War. In March 1875, Francis Hill, Captain of the Natal Hussars, a cavalry corps formed in October of 1865 , requested permission from the commander-in-chief to remove two members; Trooper P.G. Lietsman and Corporal J.

Alcock. Both men, according to Hill, had not attended drill since May of 1873, and had received fines but had failed to answer notices. The letter showed a distinct level of command structure that had developed in Natal following the revised Volunteer Laws of 1872. Captain Francis was not empowered to dismiss these two troopers, and was therefore forced to move his concerns "up the chain of command." The recommendation for dismissal was submitted by the commander-in-chief, and the two men were dismissed after notices were sent and proper time was allowed for response. Moreover, Captain Hill's language in his letter illustrates a level of disdain and dismissal of these men who were intended to be under his 
command, calling them "an encumbrance to the corps and not amenable to discipline of any kind" ${ }^{185}$ Troopers could not simply join these organizations and then not take part in their duties without being noticed. For one, the size of these corps would simply not allow such activities, especially in the cavalry corps like the Natal Hussars, whose numbers had dropped by 1875 from 65 and 55 between 1870 and 1873 respectively, to 29 by $1876 .{ }^{186}$ This exchange also illustrated the principles that many officers held for the necessity of these volunteer corps to defend the colony and uphold what was becoming a type of military tradition within the colony.

Such incidences became more and more common as the colony of Natal drew closer into conflict with the Zululand in 1878. In July and August of 1878, the Second Clerk of Customs, E. Charles M. Tynell, requested six days leave of absence to attend the Durban Mounted Rifle Volunteer's "Camp-Out”. Such activities would have been part of the standard period of drills for members of the volunteer corps, with Tynell taking the appropriate precautions in his request by prearranging with the Warf Clerk, a Mr. Cochrane, to take over his duties while away. Tynell emphasised that Cochrane would not cause "extra charge or expense to the Government." 187 Despite these precautions, there was an air of frustration from the collector of customs as he forwarded the request to the colonial secretary. Mr. Rutherford posits that he had not been made aware of Mr. Tynell joining the volunteer corps. If he had been, Rutherford would have advised Tynell against joining, largely due to the possibility of it "clashing with his immediate and proper duties as an Officer of Customs." 188

\footnotetext{
${ }^{185}$ Dismissal of two troopers of the Natal Hussars, March 30 1875, CSO 512 No. 999, 1875.

186 "Military", Natal Blue Books, 1870-1876.

${ }^{187}$ E. Charles M. Tynell, Second Clerk to Geo. Rutherford, Collector of Customs, July 31, 1878, CSO 658 No. 2864, 1878.

${ }^{188}$ Geo. Rutherford, Collector to Colonial Secretary, August 20, 1878, CSO 658, No. 2864, 1878.
} 
Rutherford's comments illustrate not only a continuing problem with the volunteer system from within the colony, but also the conflicting interests that these volunteers would have to contend with in balancing their lives outside of the corps with the service required to maintain their membership. Rutherford's view of the volunteer corps as a distraction and threat to the stability of colonial revenue shows a clear apprehension for the divided loyalties such systems represent. Membership in the corps would only "distract from the efficient attendance to their proper duties" with "confusion and embarrassment" sure to arise. ${ }^{189}$ Rutherford even went so far as to allow Tynell leave of absence under the description of "health and education" instead of the official grounds of the request. Conversely, the office of the lieutenant-governor was unwilling to discourage anyone from completing their service in the volunteers and provided Tynell with final approval.

As troops began to muster for the coming war with the Zulu, many individuals were forced to come to terms with their "divided loyalties" within the colony. Those who worked on the railway were given such a "choice" in writing. One such individual, a J.P. Lymon, Jr. was ordered on November $29^{\text {th }}$ to either resign his position in the Natal Carbineers or his employment in the Natal Government Railway, with the district engineer suggesting that Lymon resign from the volunteers. Unfortunately, Lymon had already received orders on November $24^{\text {th }}$ that the Carbineers had been called out for active service. This placed Lymon in what was viewed as a serious conundrum. Since he had already reported to the front and it was impossible for Lymon to leave with the threat of desertion hanging over him, he was faced with the choice to "resign or be disgraced [on which he] preferred to adopt the former course." ${ }^{190}$ Lymon is a clear example of the overwhelming sense of duty that the volunteers exhibited both to their positions in the corps, but also to the government they defended.

\footnotetext{
${ }^{189}$ Geo. Rutherford, Collector to Colonial Secretary, August 14, 1878, CSO 658, No. 2864, 1878.
}

${ }^{190}$ J.P. Lymons Jr. to the Hon. Colonial Secretary, December 4, 1878, CSO 670, No. 4544, 1878. 
Lymon illustrates the deeper conflict that took place within the volunteers during wartime. ${ }^{191}$

Lymon's attitude, however, is not entirely that of an enthusiast for the war, especially when he admits that if the notice from the railway had arrived earlier, he would have had a legitimate reason to resign from the Carbineers. Troopers did not always choose the volunteers over their other activities within the colony.

Alfred Tucker of the Newcastle Mounted Rifles requested on December 2, 1878 that he be exempt from active service. Tucker's reasoning rested on the contracts he had acquired for the supplying of troops at Newcastle, Derby, and the Utrecht District which would "be impossible...to fulfill if I proceed with the Volunteers to Helpmekaar [the staging area for the front just east of Dundee].”192 Colonel Evelyn Wood, commander of the fourth invasion column, agreed, informing the military secretary that the fulfilment of this contract was "of primary importance to the troops" especially in light of Tucker being partners with Mr. White, the man contractor. ${ }^{193}$ This relationship with the contractor was seen as so invaluable, Tucker was insured his place away from the lines. Though Tucker was in a unique position to aid the war effort while staying away from the front, he seems to represent the minority of troops who remained with their corps.

Perhaps one of the most striking incidents of this chain of command and the ambiguity of discipline during the Anglo-Zulu War of 1879 involving the Durban Mounted Rifles. Founded in 1873 by F.W.B. Louch, by 1879 the unit was under the command of Captain W.E. Shepstone, the son of the former Secretary of Native Affairs, Theophilus. The

\footnotetext{
${ }^{191}$ Though outside of the scope of this dissertation, these responses from soldiers during wartime is a unique opportunity to not only analyse the ideas of loss away from the home front but also problems of masculinity and conflict. Recent studies on German militarization in the nineteenth century are particularly revealing from a comparative perspective. See Ute Frevert, A Nation in Barracks: Modern Germany, Military Conscription and Civil Society, First Edition edition (Oxford ; New York: Bloomsbury Academic, 2004).

192 Alfred Tucker to the Hon. Colonial Secretary, Newcastle, December 2, 1878, CSO 671, No. 4622, 1878.

${ }^{193}$ Evelyn Wood, Colonel to the Military Secretary of Lord Chelmsford, December 3, 1878, CSO 671, No. $4622,1878$.
} 
unit was assigned to Pearson's column during the invasion and avoided the catastrophe at Isandlwana. ${ }^{194}$ By March 1879, the unit had been in the field for over three months, and some members of the corps did not wish to continue taking part in the war. Three troopers request to Captain Shepstone that they be allowed a leave of absence to "go down to the Tugela and take a chance of getting into a corps going across the river". ${ }^{195}$ The idea behind this request was to leave the campaign without outright desertion by transferring to a unit that was mustering out. The request was summarily refused by Shepstone. In response, Troopers Fred Brooke and John Maydon attempted to flee the camp, only to be caught before leaving the picket line. Instead of charging the troopers with desertion, Shepstone chose to simply charge the men with insubordination and fined the men appropriately. The reason for this light punishment is unknown, but Shepstone was assumedly attempting to avoid the show of a court-martial and the possible disciplinary problems it would cause in the unit.

Brooke and Maydon were unsatisfied with this result, and directly petitioned the lieutenant-governor for approval of a court martial and further investigation of the charges. Why? Shepstone suspected that Brooke and Maydon were hoping the court martial for desertion would force the corps to remove the two troopers from the field and in so doing, take them out of harm's way. In essence, Brooke and Maydon were attempting to be kicked out of the corps. Captain Shepstone suspected that the men wished to leave the front so they could have the chance to return to Natal and take advantage of the opportunities for wealth provided by the war effort, such as Alfred Tucker of the Newcastle Mounted Rifles had done. Unfortunately for Brooke and Maydon, their understanding of the outcomes of their actions were less ideal.

\footnotetext{
194 Though it had not been completely unscathed. The Pearson's column faced five Zulu regiments during the early campaign. For an account of the "Flanking Column" See: Morris, The Washing of the Spears, 421-433.

195 W. Shepstone, Captain, Com. of Durban Mounted Rifles to the Acting Com. of the Volunteers, Pietermaritzburg, April 4, 1879, CSO 697, No. 1901, 1879.
} 
According to the attorney general who reviewed the case, because the unit was "now in the field on actual Military Service" the rules of the Volunteer Law of 1872 were overruled by the Mutiny Act of 1855 . In such a case, officers or volunteers would face the same discipline and punishment "under the provisions of the Mutiny Act and Articles of War as if they were officers or soldiers of Her Majesties regular army" though they would not face corporal punishment, as stated in the addendum to the Mutiny Act in conjunction with the volunteer law. ${ }^{196}$ Shepstone must have been fully aware of this possible outcome, as he stated to the colonial secretary that his intention of not bringing up the charges of desertion was largely an attempt to avoid the troopers being confined to penal servitude, the probable outcome of a court martial. The attorney general would recommend that the original punishment placed on them by Captain Shepstone would be appropriate and no additional court martial proceedings would be necessary. The lieutenant-governor approved and the matter was closed.

This incident illustrates the extent to which some volunteers would attempt to remove themselves from the hostile environment they found themselves in during the war in 1879. The primary interests and goals of these young men did not rest in the Zululand, but instead within Natal. It is particularly telling that, according to Captain Shepstone, these men were "three of the youngest members" of the corps. ${ }^{197}$ The volunteers were more citizens than soldiers. This does not imply that the troopers who took part in the Anglo-Zulu War did not perform adequately, but instead illustrates the priorities of the troops that marched across the Tugela River in 1879. Even when troops did not perform exemplary, they were still treated

\footnotetext{
${ }^{196}$ Such instances would continue to occur in the wake of an increased military presence in Natal following the Anglo-Zulu War, including one incident in 1881 in which a mule driver for the Commissariat was ruled to exist within the same rules and regulations as a soldier, meaning he could not sue the officers for lost wages in the Civil Court of the Colony. See Natal Law Reports: Supreme Court (Pietermaritzburg: Munro, 1902), 164-165.

${ }^{197}$ Shepstone to Com. of the Volunteers, April 4, 1879, CSO 697, No. 1901, 1879.
} 
with a respect and softness that would not have typically been offered to troops of the British Army.

All officers in the volunteers were dealing with the first major campaign in their corps' existence. In light of this, questions over legality were nothing particularly unique. At the siege of Eshowe, a member of the Alexander Mounted Rifles was charged with cowardice. The deputy adjutant general, Colonel Bellairs, was unsure of the proper proceedings, initially wavering between military tribunal and corporal punishment. It was quickly pointed out to the military by the colonial secretary's office that while the trooper "may be tried under the Mutiny Act...he is not liable to corporal punishment". ${ }^{198}$ The trooper, who remained unnamed would be tried by a tribunal of officers from his own corps and receive his punishment within the parameters of the volunteer law. Another telegraph to the attorney general's office from Major General Crealock also inquired as to why a Trooper Nieker of the Natal Hussars had not been tried. Crealock was unsure if the trooper was liable for a trial at all or under what method it could be done. Again, the attorney general stated he could be tried while in actual military service under the volunteer laws, but once again could not be subjected to corporal punishment. ${ }^{199}$ Details of the trooper's actions are not included in these reports, but such activity from the young men of Natal would be the source of considerable anxiety from the colonial population on the home front.

The exposure to the front among "these young men of Natal" was a grave concern for many members of the Natal community. This grew even more apparent in the ensuing months as the war dragged on, even though most of the major fighting for the volunteers subsided with arrival of more imperial troop reinforcements after Isandlwana. Some back in

\footnotetext{
${ }^{198}$ Natal Electric Telegraph: Colonial Secretary, Pietermaritzburg to Deputy Adjutant General, Durban, April, 15, 1879, CSO 697, No. 1978, 1879.

${ }^{199}$ Major Gen. Crealock, Fort Pearson to Attorney General, PMBurg, May 22, 1879, AGO I/8/20, 138A/1878.
} 
the colony feared their young men were becoming negatively affected by the front. William Palmer, former mayor of the city of Durban, petitioned the lieutenant-governor to allow the volunteers to "return to their homes and their ordinary engagements." 200 Palmer points out that the reinforcements, especially the cavalry, which had arrived in the colony was a clear illustration that the services of the volunteers were no longer needed. Moreover, the former mayor worried that the "nomad life" of a soldier on campaign would seriously impact their character, and threatened to "destroy the prospect of many of them settling down again to citizen life."201 This concern that the young men might be changed by war was less in line, surprisingly, with the popular nineteenth century idiom that war "built character". Instead Palmer openly admits: "I naturally feel the anxiety for the future welfare of our colonial youth. I see a danger which will arise for want of the ordinary restraints of home and domestic influence."202 Palmer's concerns could be easily dismissed as concern for the wellbeing of the colony post war, especially with his purveying interest as a politician and businessman. ${ }^{203}$ His comments could even be more easily brushed aside because he had a nineteen year old son who was in the Zululand with the Durban Mounted Rifles. Palmer's apprehension, however, about the moral and mental state of the troops did have particular relevance as the war would continue into its fourth month.

On April 30, 1879, a petition was presented to the Lieutenant-Governor Ernest Bulwer written by T.R. Haddon and signed by the 33 members of the community of Newcastle on behalf of the Newcastle Mounted Rifles. In it, the community requested that their volunteers be allowed to return to their homes. They cited the five months which had

\footnotetext{
${ }^{200}$ W. Palmer to the Hon. Major Mitchell, Colonial Secretary, April 9, 1879, CSO 697, No. 1930, 1879.

201 Ibid.

202 Ibid.

${ }^{203}$ Palmer would go on to become the Representative of Durban County from 1897 to 1902 . He also established the firm Wm. Palmer \& Son, Smith St., Accountants, Trustees, Secretaries, Agents, etc. See, The Natal's Who's Who Publishing Company, The Natal Who's Who: An Illustrated Biographic Sketch Book of Natalians (Durban, South Africa: Robinson \& Co, 1906), 153.
} 
passed since they first took the field on December 3, 1878 and their prompt and enthusiastic response to the summons to muster. Particular reference was made to this point not only because "such a relinquishment of home \& business was to many... a great sacrifice" but also due to the corps losing around one fifth their numbers in the ensuing war. ${ }^{204}$ Though this sacrifice of life was an important point to the memorial, greater emphasis was placed on the long term impact this deployment would have on the livelihood and prospects of the men of the corps. The absence of these men, according to the memorial, not only cost the men valuable time, but would also cost them valuable business prospects or position. To illustrate that their absence would not only hinder the men of the volunteers, the memorial highlighted that these loses would press "with an incalculable severity on not only the men themselves but on those dependant [sic.] on them and on the town \& district of Newcastle." 205 This included the businesses, wagon building, and blacksmithing establishments in Newcastle which had been closed since December due to the absence of their owners or workers.

The petitioners did not make this memorial with the express intention of limiting the number of forces available in the war, but instead it was once again a response to the reinforcements that had arrived the month before. In light of these regular troop reinforcements, the community believed that the corps' services was no longer necessary, and their sacrifice being enough for their volunteer service. Instead, they "do not wish to ignore the duty of all colonists to meet cheerfully any sacrifice necessary for the public good but in this case submit that the sacrifice is unnecessary any longer and presses with great and most unequal severity on many especially on heads of businesses and of families."206

\footnotetext{
204 The Memorial of the undersigned inhabitants of Newcastle to His Excellency Sir Henry Ernest Bulmer, Lieutenant Governor of the Colony of Natal, April 30, 1879, CSO 700, No. 2234, 1879.

205 Ibid.

206 Ibid.
} 
The lieutenant-governor forwarded the information to the Major Dartnell, commanding military district one, which included the Klip River region and Newcastle. ${ }^{207}$ Both Dartnell and Bulwer agreed that it would be impossible to recall the volunteers under the current circumstances. Dartnell suggested instead that because of the length of time of their period of service, some kind of leave system should be established that would allow for a certain percentage of the troops to systematically return to their homes for a short period of time. Dartnell's initial suggestion was twenty percent of each corps would granted 14 days leave, and "that in some cases men may be allowed to provide substitutes" for their service. ${ }^{208}$ Eventually, a circular was distributed to the volunteer corps in the field that each unit would be authorized ten days leave, with five to ten percent of the men leaving at a time.

This concession to public demand again illustrates how the volunteer corps were not simply an extension of the British Army, but instead part of the network of control that existed within the colony. Not only were these volunteers important members of the community, they were also part of the fundamental nature of economic and social security within the colony. The volunteers during the build-up to the Anglo-Zulu War were a point of pride to some, but to many it was a means to cope with concerns about collective security and the possibility of invasion.

By the conclusion of the Anglo-Zulu War, the volunteers had become a symbol of the power of action amongst the European colonist, whether legitimate or a facsimile. The number of deaths in many volunteer corps like the Newcastle Mounted Rifles became part of

\footnotetext{
${ }^{207}$ On the eve of the Anglo-Zulu War on November 23, 1878, the colony of Natal was divided into seven "defensive district" each with a "District Commander" who oversaw the preparations for the defence of the colony, including the calling out of volunteer corps.

${ }^{208}$ Again, under many corps rules and bylaws, troops would not be permitted to leave the unit over a short period of time unless they were able to find an individual who would take their place and pay a fine. For the business men in the volunteer corps, this would be an opportunity to return to their businesses without facing court martial for desertion. J. Dartnell, Major, District Commander No. I Division to Inspector General, May 5, 1879, CSO 700, No. 2234, 1879.
} 
their collective importance to the colony as a whole, just as the death of the Carbineers during the Langalibalele Rebellion marked their significance to Natal's defence. More importantly, their actions in requesting to return to their homes did not diminish their standing within the colony. In November the same year, another memorial was put forward, but this time to request the erection of a "Memorial Hall" in Newcastle to commemorate the services of the volunteers in the colony. ${ }^{209}$ Nowhere in this memorial is the previous request to return home before the end of the war mentioned. Nowhere does it discuss the economic contributions that those who returned home made on Newcastle (though a number of signatures are the same for both memorials). Instead the call for commemoration illustrates the unique place that the volunteers retained in the consciousness of the people of Natal, and the nature of service and defence in the colony of Natal as a whole.

\section{Conclusion}

Though the volunteer corps acted as only one example of a Natal's military institutions, they reveal the greater militarization of society which continued throughout the formative period of the colony, from the British Annexation of Natal in 1843 to the AngloZulu War of 1879. Government regulations between the enactment of the Volunteer Law of 1854 and the Volunteer Regulation Act of 1877 illustrate the evolving nature of these concerns within the colonial state, as well as legitimate concerns for the issue of security. The volunteers, despite their many failures, would remain one of the most widely praised and publicized component of Natal's military web of structures.

As has been shown, there remained considerable debate over their discipline, practicality, cost, and even military viability when called upon within Natal society. Because the ruling elite of the colony were an active part of this institution, it would continue to retain

209 T.R. Haddon, Newcastle: Memorial for construction of a Memorial Hall in Scott Square Newcastle in recognition of the services of the Newcastle Mounted Rifles, October 20, 1879, CSO 727, No. 5034, 1879. 
the support of many members of the colonial community and government. The idea of the volunteers as a successful institution continued to evolve and change over the formative period and lingered to influence thoughts of security within the colony for decades to come. Whether these thoughts were related to the implementation of new rules and regulations, the democratization of defensive structures, criticism of the failings of such regulations, or simply an attempt to address what must have been the major concerns of many colonists within Natal, these military systems cast a clearer picture of the volunteers' role in the formation of Natal as a colonial state and society within the British Empire. 


\section{Chapter Four: European Police}

\section{Introduction}

David Killingray, a pioneer in the history of colonial police and soldiers in Africa, stipulated that effective colonial government rested on two pillars: the collection of revenue to finance the colony and the maintenance of law and order to preserve the administration of the colonial state. At the founding of the colony of Natal in 1845, it possessed neither a system of revenue and finance, nor more importantly a police force which would allow it to maintain some semblance of colonial security. A fully functioning police force would not be established in the colony until the 1850 s and an organized and well-disciplined unit of police would not exist until the Anglo-Zulu War. Yet, by 1906, the colony of Natal was able to produce a 190 page set of police rules and regulations with detailed instructions and parameters on how to deal with all elements of the colony, from railways to thefts to agricultural problems. ${ }^{1}$ Within 50 years, Natal had established a police force that became a critical element in its internal security and fully established itself as a "pillar" of colonial authority. ${ }^{2}$ This chapter will attempt to address how the police and law enforcement systems within Natal acted as a key example of a society attempting to come to grips with the problems of security and safety which continued throughout the formative period of the colony.

There was no single unified system which the colonial authorities attempted to establish during this period. Local constabularies were strikingly different from their rural counterparts, and the only European police institution which addressed the colony as a whole was the Natal Mounted Police, officially created in the 1860 s but not solidified as a colonial

\footnotetext{
${ }^{1}$ Natal Police Force: Revised Rules and Regulations (Pietermaritzburg: P. Davis \& Sons, 1906).

${ }^{2}$ By the twentieth century, Durban was thoroughly modern police force, as seen in multiple incidents collected in Paul Maylam and Iain Edwards, The People's City: African Life in Twentieth-Century Durban (Pietermaritzburg: University of Natal Press, 1996).
} 
institution until 1875. Though the Natal Mounted Police, and later the Natal Police, would normalize the level of discipline and consistency (if not fairness) in the police system of the colony following the Anglo-Zulu War, topics of expense, security, racial divisions, and the extent of violence and criminality within the colony were all galvanized during this formative period. Without the creation of some institutions that could answer these problems of internal security, Natal would be unable to fully establish itself as a viable colonial state during the latter half of the nineteenth century. Though this chapter will focus largely on the European police institutions within the colony, the models and methods of colonial policing were transferred extensively to the European's African counterparts. As the next chapter will reveal, many of the same rules and regulations that dictated police action applied to all police, both white and black. Nevertheless, the Natal Mounted Police and its predecessors did represent some attempt to form an exclusively European system of police control (though there were Africans within these same institutions). Despite this attempt at exclusiveness, there will be considerable overlap between this chapter and the next when examining the nature of colonial police work within Natal.

Police have been widely accepted as a key component in the development of the modern state in Europe and the West. Eighteenth century Hanovarian publicist Johann von Justi contended that "police in the strict sense refers to everything needed for the maintenance of civil life, thus for discipline and order and well-being among the subjects in the town, and for the growth of the peasantry."3 Modern police were perceived as an institution of progress which defined ideas of free enterprise and fair government, and were fundamental in the emergence of the modern state system. This perception, according to Liang, solidified as domestic politics overshadowed foreign affairs, and was pushed forward along with

${ }^{3}$ Friedrich C.B. Avé-Lallemant, Physiologie der duetchen Polizei (Leipzig, 1882), quoted in Hsi-huey Liang, The Rise of Modern Police and the European State System from Metternich to the Second World War (Cambridge [England]; New York: Cambridge University Press, 1992), 1. 
Rousseau's "general will" that linked perfect police control with the age of democracy. ${ }^{4}$ Such “enlightened" assessments were typically why police and police institutions were viewed as an important component in the development of Western states during the nineteenth century. Nonetheless, the police's role in colonial encounters has been less defined. ${ }^{5}$ Despite attempts to place most colonial police under a specific model or system (usually either that of the London Metropolitan Police, also known as the "New Police", or the Royal Irish Constabulary), it has become generally accepted that policing in the colonies had many distinct qualities that separated it from its European counterparts, especially in Britain. ${ }^{6}$ Moreover, as Anderson and Killingray have asserted, unique institutions and structures of authority in the colonial setting illustrated a powerful coalition of interests that forced more direct actions in the colonies, demonstrating that it would be wrong to "assume that policing the empire was much the same as policing Limerick, or London, or Leicestershire."7

According to Sir Charles Jeffries, creator of one of the founding works on colonial police, in Africa there were typically two lines of development that took place in the establishment of police institutions, which mirror in many ways the methods of control imposed by the Europeans during the age of colonization. One involved the creation of organizations headed by African rulers which were trained into local police forces that did not report to the central government but instead to local authority "on the analogy of county

\footnotetext{
4 "Perfect police control" can be applied to the concept of an organized police system with strong links to civil establishments formed by the state and managed in a relatively complete bureaucratic system. Ibid., 8-9.

${ }^{5}$ Even Liang notes that his term of "modern police" did not apply to European colonial police in Africa and Asia during the nineteenth century, "where the exploitative relationship of colonial masters to native inhabitants was frankly admitted." Ibid., 4.

${ }^{6}$ This new approach challenges the assumptions from work on English police institutions that assert an English model was used for urban policing and an Irish model for rural with the British Isles and while "both were exported...the Irish dominated the colonies." See Stanley H Palmer, Police and Protest in England and Ireland, 1780-1850 (Cambridge: Cambridge University Press, 1988), 711-715.

${ }^{7}$ David Anderson and David Killingray, eds., Policing the Empire: Government, Authority, and Control, 18301940 (Manchester, UK: Manchester University Press, 1991), 4-5.
} 
and borough police forces in Britain."8 The other would be a police force that reported to the central government and extended its influence over the whole of the colony, "absorbing or replacing any local bodies which in the past have functioned in some way in lieu of a proper police force."9 Natal, however, did not fall strictly under either of these conditions, but instead created a hybrid system that challenged the general need for the creation of a standard of efficiency and impartiality that was the responsibility of the colonial government. The striking divisions between urban and rural and the lack of an organized plan from Natal's government ensured that the formative period of Natal's police forces was anything but simply defined. Jeffries does provide a key blueprint that will aid in understanding how Natal's police institutions developed during this formative period, but these unique elements illustrate the colony's distinctive development compared to other segments of the Empire.

\section{Early Colonial Police}

The police institutions within the colony of Natal represent an attempt to maintain law and order along the British frontier. The frontier marked, as Killingray describes, "the temporary limit of conquest, administration or settlement." 10 These "troublesome or backward regions" would require unique types of policing and special forms of administration compared to the police institutions of other colonies. Natal's police forces, both white and black, represented imperial authority responding to concerns on that frontier. Far from the Ballarat of Australia, Natal did experience rapid growth within the first few decades of its existence, creating an ever growing need for organized police institutions that would be able to implement law and order seen as crucial to the development of Natal as a

\footnotetext{
${ }^{8}$ Sir Charles Jeffries, The Colonial Police (London: Max Parrish, 1952), 6-7.

${ }^{9}$ Ibid., 7.

${ }^{10}$ Anderson and Killingray, Policing the Empire, 6.
} 
colonial state. ${ }^{11}$ This process, however, was gradual and only slowly developed after the establishment of Natal's colonial government and political order in the 1840s and 50s.

Natal possessed anything but a highly organized police institution during its early years in the late $1840 \mathrm{~s}$ and $1850 \mathrm{~s}$. This was clearly evident in the police's cost and organization. The vast majority of police work was actually accomplished by the Natal Native Police Corps, a sizable organization that would eventually be disbanded by Lieutenant-Governor Benjamin Pine in $1851 .^{12}$ Small constabulary forces in both Pietermaritzburg and Durban represented the vast majority of police presence within the colony outside of this Native Police force. These urban constabularies, however, did not necessarily expand in their scope following the disbanding of the Native Police in 1851. Between 1850 and 1854, the cost of the colony in police and gaols actually decreased from $£ 1382$ to $£ 627$ (a decline of roughly $£ 200$ a year). The number of men appointed to the colony also dramatically dropped during this period. In 1850, Pietermaritzburg had 12 constables (all European considering their pay of $£ 36$ a year) and Durban claimed five constables. The remainder of the police force was stationed in the Klip River District composing of two European constables and eight "native" constables. ${ }^{13}$ The number would dramatically decline within four years. By 1854, Durban and Pietermaritzburg retained the most number of officers, with six European and four to five Africans. But the other divisions of the colony possessed no more than one European constable and in some cases only African

\footnotetext{
${ }^{11}$ Perhaps the more appropriate metaphor can be linked to the small town of Middlesbrough, first described as a "British Ballarat" by Asa Briggs. The metaphor compares the growth of Middlesbrough with the frontier town of Ballarat in Australia. Links could perhaps be made between the dramatic industrialization of this northeastern England and the transition from agriculture to industry which dominated parts of the colony of Natal during the nineteenth century. David Taylor also claims that Middlesbrough had the reputation as a turbulent town, exhibiting "frontier town" qualities, which has been used as a comparative analysis. See Asa Briggs, Victorian Cities (London: Odhams Press, 1963); David Taylor, Policing the Victorian Town: The Development of the Police in Middlesbrough C. 1840-1914 (New York, N.Y.: Palgrave Macmillan, 2002), 52.

12 See Chapter Five: African Police.

13 The use of the term "native constable" was the primary designator for non-white members of the constabulary. It can be assumed that all of these were indigenous Africans, as Indian constables only appear in the colonial records beginning in the 1860 s and are specifically distinguished as such.
} 
constables. The decline in numbers was indicative of two factors: the increased disparity that existed between the urban centres of the colony and the other divisions, and the increased reliance's on fewer and fewer officers to patrol and administer the colony due largely to the need for greater fiscal responsibility from the Natal colonial government. ${ }^{14}$ Such a lack of Europeans within the districts as a whole would be a constant theme within Natal throughout the formative period of the colony.

Regardless of this decline in numbers, the constabulary of Natal did fulfil a critical need within the colony when they were capable, that of a law enforcement division set on keeping the peace and apprehending offenders. As the physical representatives of the local resident magistrates, the police were responsible for the implementation of British law where it was relevant. Crimes against the Crown were the most typical instances that drew the police's attention, as was the case in 1854 when constables searched the Umvoti Location for an African charged with murder. Searching the bush was the primary job of the constabulary, whom in this case consisted of only one European and four Africans, though it was eventually revealed that the suspect was under the protection of the local chief, making the task nearly impossible. ${ }^{15}$ Because of the nature of Natal's legal system, administered extensively by Shepstone, the local chiefs had considerable power over domestic affairs. Capital crimes, such as murder, though usually handled by the local resident magistrate and administrators of native law, sometimes fell under the chiefs jurisdictions', varying extensively to the power and tendencies of each chief. ${ }^{16}$ It was not until the Native

\footnotetext{
14 “Expenditures", Natal Blue Books, 1850, 1854.

${ }^{15}$ Lloyd Evans Mesham, Resident Magistrate Inanda Division to Walter Harding, Crown Prosecutor, July 31, 1854, AGO I/8/3, No. 132A/1854.

${ }^{16}$ Short summary of "Native Law" in Natal can be found in Norman Etherington, "The 'Shepstone System' in the Colony of Natal and Beyond the Borders," in Natal and Zululand from Earliest Times to 1910: A New History (Pietermaritzburg [S. Africa]: Univ of Natal Press, 1989), 171-175.
} 
Administration Law of 1875 that such discrepancies were addressed in the creation of a Native High Court. ${ }^{17}$

Other cases were much more manageable, such as the following September were the constabulary of Ladysmith, also consisting of only one European and four Africans, apprehended two individuals suspected of stealing a large amount of money from the home of Captain Struben, Resident Magistrate of the Klip River. Johann Marinus Struben, a settler from 1850 born in Holland, was a probable target of such an attack. Not only was he particularly well known as a friend of Lord Byron, the former squadron commander and husband to the daughter of a Scottish shipowner was feasibly in possession of some tangible wealth. ${ }^{18}$ Struben's position also possible contributed to the speed at which suspects were apprehended in his case, though such speed did not work in the police's favour. After a short inquiry, the suspects were released, and though the police would continue to look for the robbers, the case was left a "mystery." 19 Such was the case for many of the crimes within the colony during this early period.

Though criminal statistics did not become a common component of the yearly colonial reports until 1872, the number of prisoners placed in gaol was illustrative, at least to some degree, of the effectiveness, or lack thereof, of the police force. Interestingly, despite the greater financial burden the colonial government placed on the police forces starting in 1850 , the force was far more productive in the number of tried felony and misdemeanour cases in that year than at any point until the 1870s. Eight Europeans and 50 Africans were tried for felonies and 68 Europeans and 195 Africans tried for misdemeanours in 1850.

\footnotetext{
${ }^{17}$ Guy speculates that with the law's passage, it marked "the end of the Shepstone era in the history of Natal." See Guy, Theophilus Shepstone and the Forging of Natal, 457.

${ }^{18}$ Hattersley, The British Settlement of Natal, 100.

${ }^{19}$ Henry Fuller, Clerk of Peace to the Crown Prosecutor, Pietermaritzburg, September 3, 1854, AGO I/8/3, No. $142 \mathrm{~A} / 1854$.
} 
Compared to the next ten years of data, only around eight Europeans and 24 Africans were tried for felonies and only four Europeans and 19 Africans on average were tried for misdemeanours (which were broken down between theft, assault, and other starting in 1855). ${ }^{20}$ The vast majority of these prisoners were men, with only four cases of European women and only 50 one cases of African women being tried for any crimes between 1850 and 1870 (with 23 of these cases against African women taking place in 1850). Such data does little to illustrate the effectiveness or even the true propensity of the police to apprehend criminals, but they do illustrate that with a few exceptions, the criminal statistics for the colony remained relatively stagnant following the initial surge of the police force in 1850 , due to the lessening of the number of the constabulary within the colony, and presumably the disbanding of the Natal Native Police.

The declining numbers in the police force did not, however, produce an overabundance of quality personnel in the remaining police positions, even for the chief constable of Pietermaritzburg. In July 1852, a Mr. Hoffmann corresponded with Walter Harding, the Resident Magistrate of Pietermaritzburg, on the conduct of his neighbour, Chief Constable Johnstone, who was characterized as seeming "bent upon disturbances rather than to keep the peace." ${ }^{21}$ Evidently, the Saturday before, a confrontation had taken place which involved Johnstone screaming "Hoffman" into the streets in what appeared to be an angered state. What was the source of his frustration? Gardening. Evidently, Johnstone had confronted a local gardener, Harman Bosle, about the state of Mr. Hoffmann's hedges. Johnstone had claimed to Bosle that Hoffman had somehow killed the chief constable's ferns and "[chased] his ducks away from his garden". ${ }^{22}$ As recompense, Johnstone would demand

\footnotetext{
${ }^{20}$ Average statistics compiled from "Gaols and Prisoners", Natal Blue Books, 1850-1859.

${ }^{21}$ Mr. Hoffmann to Water Harding, Resident Magistrate of Pietermaritzburg, July 19, 1852, AGO I/8/2, No. $51 \mathrm{~A} / 1852$.

${ }^{22}$ Statement of Harman Bosle, 19 July 1852, AGO 1/8/2, No. 52A/1852.
} 
as much as $£ 10$, which seemed like a staggering sum to Bosle. Johnstone was not finished, and decried Mr. Hoffmann as "anything but a gentleman" who seemed inclined only to use people for money. The chief constable concluded what must have appeared a rant by calling Mr. Hoffmann a "common schoolboy" and a "smeerlap" (the Dutch word for "bastard" or "scoundrel"). Mr. Bosle, who had no answer for Johnstone beyond noting the inappropriateness of his comments, suggested that Johnstone bring up these issue to Hoffmann himself. Johnstone responded that it was partially Bosle's fault and that he "must not be impudent or else take care of him", implying that Johnstone wanted his problem solved either through free labour or payment. ${ }^{23}$ The incident seemed to end there, with Mr. Hoffmann making a complaint to the resident magistrate and doing what he called "a duty toward myself and the public to represent such at the proper quarter." ${ }^{24}$ Though almost laughable, and indicative of the importance of personal property in early Natal and to an extent the English garden in this frontier region, the incident does represent one major challenge that was taking place in Natal during the early 1850 s. Johnstone, with his use of the term "smeerlap", exemplified the influence of the Afrikaner population within the community. This would make some sense as Johnstone had retained the position of chief constable since August 1850, and retained some contact with the Afrikaner community in Pietermaritzburg. Hoffmann, being called a "schoolboy", conceivably represented the new wave of British immigrants who were arriving in the colony during the early $1850 \mathrm{~s}$. As chief constable, Johnstone saw the need to assert himself over the new arrivals while at the same time voicing the frustration that existed in much of the older settler community over encroaching immigrant influence and authority. In the end, Johnstone presumably weakened

\footnotetext{
${ }^{23}$ Ibid.

${ }^{24}$ Mr. Hoffmann to Water Harding, Resident Magistrate of Pietermaritzburg, July19, 1852, AGO 1/8/2, No. $51 \mathrm{~A} / 1852$.
} 
his own position in the colony and removed what little credibility he retained with the newer immigrants.

The conduct of the chief constable of Pietermaritzburg likely led to his discharge and the appointment of a new chief constable on September 3, $1852 .{ }^{25}$ Johnstone would return to government work within the next three years, being appointed the interpreter for a resident magistrate. Johnstone's counterpart in Durban, Mr. Lee, was also accused of mistreatment and conduct unbecoming of an officer in his handling of a prisoner in July 1853. Lee also was replaced within the year by a Mr. Harrison, while Lee became the second tide master of the customs house. ${ }^{26}$ Because Johnstone and Lee were settlers who predate British authority, such actions are strongly indicative of the staying power of many of the early settlers of the colony, but also the limited number of European human resources available for any sort of proper administration in Natal. The misconduct of the chiefs of police within the two main urban centres of the colony also precipitated a level of frustration in these towns that would eventually lead to their separation from the police forces of the colonial government.

\section{Local Control}

Natal's police institutions, though in their infancy, had already elicited debate and concern within the colonial government and from local authority that saw their necessity for colonial security. The town boroughs especially saw the need for some level of independence from central control. By 1854, the parameters of police forces in the boroughs of Durban and Pietermaritzburg were solidified under the "Ordinance for establishing Municipal Corporations within the District of Natal". ${ }^{27}$ Though these forces were granted a greater level of independence within the growing cities, they were still part of the colonial government to a

\footnotetext{
25 "Expenditures", Natal Blue Books, 1852.

26 “Expenditures", Natal Blue Books, 1855.

${ }^{27}$ Moodie, Ordinances, Proclamations, 387.
} 
large degree. One half of the cost of maintaining the police was paid by the boroughs, with the other half paid out of the public treasury of Natal. The police forces were under the command of a "police board", composing the mayor, one councillor, and the resident magistrate, and retained considerable power for the colonial authority versus the municipal governments. In Durban, Mr. William Harrison acted as Durban's chief constable with the assistance of six constables. ${ }^{28}$ The lieutenant-governor, however, still possessed the power to appoint and remove constables and "make regulations touching their number, pay,

allowances, and duties". ${ }^{29}$ Under such a system, the Natal central government maintained an avid hold over local police forces, leaving the resident magistrates or justices of the peace near full jurisdiction over the boroughs. Local town councils were generally unhappy with this situation, especially when taking into consideration that as long as the police board maintained control of the police forces, all fees for wine and spirit licenses, a considerable source of revenue within the colony, were collected by the Natal government. ${ }^{30}$

By 1855, Pietermaritzburg held its first "Police Board" meeting. The members included the Resident Magistrate Harding, Mayor Buchanan, and Councillor Maxwell of the local board. ${ }^{31}$ Though the meeting focused on the purchase of uniforms and the overall cost of the local police department, it was another indication of the greater autonomy of the police forces exhibited by the local municipalities. At the meeting, Harding reported that the police now consisted of six men, at salary of $£ 4$ each, one chief constable at $£ 516 \mathrm{~s}$. 8d. per month, and a gaoler at $£ 40$ per annum. However, the continually evolving links between local and district continued to be a source of debate. Mayor Buchanan enquired whether the gaoler was also to be included in the police establishment, as he thought the district gaol could hardly be

\footnotetext{
${ }^{28}$ W. P. M. Henderson, Durban: Fifty Years' Municipal History (Durban, South Africa: Robinson, 1904$), 334$.

${ }^{29}$ Moodie, Ordinances, Proclamations, 397.

${ }^{30}$ Henderson, Durban, 1904, 334.

31 "Police Board," The Natal Witness, February 2, 1855.
} 
brought under the control of the police board within the means of the 1854 Ordinance. The next week the payment for uniforms was resolved, but nothing more. Following this meeting, the police board met every two weeks reporting the business of the local police. In essence, this police board acted as a bureaucratic go between for the Natal government and the local government of Pietermaritzburg, and latter Durban assumedly since they followed similar models.

Tension over these topics would continue to grow as the populations and revenue from Pietermaritzburg and Durban continued to rise throughout the ensuing decade. By 1861 , the borough corporations had gained enough influence within the legislative council to alter the power of the towns over the colonial government. Law No. 21, 1861 "For improving and consolidating the Laws in regard to Municipal Corporations" shifted the role of the colonial government in borough affairs, including the power of the town council. Under the law, the police forces of the boroughs of Pietermaritzburg and Durban were taken over by the local corporations, leaving county police under the magistrates and colonial government. The town council could "appoint and maintain such number of city and borough Policemen, Constables, and Watchmen, as to them may seem fit or necessary". ${ }^{32}$ Perhaps more importantly, rules and regulation in relation to pay rested solely with the boroughs. With these changes, the total cost and importance of police within the colony would begin to take two paths, municipal and rural.

\section{Urbanization, Growth, and the Police}

As Natal grew, so did the resources and infrastructures that were available to the members of the colony's police force, especially within the major urban centres which acted as a crucial point of colonial urbanization. It must be emphasized that the major theme of

\footnotetext{
${ }^{32}$ Law No. 21, 1861 "For improving and consolidating the Laws in regard to Municipal Corporations," CO 180/2, 1861.
} 
colonial urbanization is about "space" and the ability to fill that space, whether with monuments, infrastructure, or ways to show the narrative of colonial ambitions and accomplishments. ${ }^{33}$ Natal's overall expansion and urbanization during this formative period was a key component of the growth of Natal as a colonial state. These growing urban centres also acted as places that concentrated government functions as well as spaces of social and political diversity during an era of growing unity and identity. ${ }^{34}$ Physical constructions within colonial territories, such as railroads and lines of communication, were used to facilitate links between colonial cities and the Empire. The incorporation of railways into police activity within the colony was just one critical component of Natal's state formation and the development of urban centres within the colony. Though the railway system of Natal was neither extensive, nor connected to all of Southern Africa, it did provide a clear indication of the expansion of the colony during the 1860 s. Railways in general have typically been seen as a means to gauge colonial expansion, especially within the British Empire. ${ }^{35}$

The expansion of the railways did not fully commence until the 1870 s, yet there were discussions within Natal's community of the need and the cost of such expansion throughout the 1860 s. As early as December 1860 , suggestions began to appear in the colony of the creation of a tramway and horse railways within Durban and the surrounding areas to expand on the established tracks in the port town. Such innovations and public works were part of a kind of global technological innovation taking part in the United States and Britain, and

\footnotetext{
${ }^{33}$ Police remained just one critical component of this element of colonialism. A wonderful example of this type of examination can be found in Wright's work on the architecture and colonial spaces of early twentieth century France; Gwendolyn Wright, The Politics of Design in French Colonial Urbanism (Chicago: University of Chicago Press, 1991), 6-7.

34 To that point, the urban centres of Natal could be described, as the Lees would call them, "nodes" in networks of exchange. See Andrew Lees, Cities and the Making of Modern Europe, 1750-1914, New Approaches to European History (Cambridge, UK ; New York: Cambridge University Press, 2007), 4.

${ }^{35}$ A critical imperial tool that helped define the colonial-metropolitan relationship in South Africa was the railway; see Kenneth E. Wilburn, Jr., "Engines of Empire and Independence: Railways in South Africa, 18631916," in Railway Imperialism, Clarence B. Davis and Kenneth E. Wilburn, Jr. ed. (New York: Greenwood Press, 1991), 25.
} 
illustrated a growing desire for the slowly developing urban centres of Natal to emulate the metropole. ${ }^{36}$ A public meeting in Pietermaritzburg town hall in 1864 , led by the secretary of the Natal Railway Company, focused on that very question of growth. Mr. Elliot argued that the improvement of the line was "not only desirable, but an absolute necessity to the progress and well-being of the colony." 37 The expanding of the railway from its seventy miles in 1864 was seen as not only a means to advance the financial standing of the colony, but also to provide an effective method of transportation in the event of military conflict or invasion. Elliot even went so far as to describe Natal as a "military colony" and "by rapid means of locomotion" the colony would improve its military tenfold: a claim that illustrated "no small advantage to be derived from railways." 38 The modern innovation of the railways was perceived as part of an overall technological evolution taking place within the British Empire, of which Natal was a small part.

Perhaps not with the idea of Natal being a "military colony" but instead a more "modern colony", by the late 1870 s the police department of Durban were making extensive use of the new railway system as a major boon to their own defensive institution. By March 1877 , the mayor of Durban requested that the borough police constables of Durban be allowed to travel on the railway lines free of charge. The impediment to cost, as well as the ability to quickly board and leave the train without concert for fare, would validate such measures and provide "the great assistance that will be rendered to the [Police] Force in

\footnotetext{
${ }^{36}$ Such calls for innovations were illustrated in the local press, see "Tramways, and House Railways," The Natal Star, December 1, 1860. The progress of global technological innovations and their links to settlers has become a growing component of the literature. See Belich's account of the steam-driven revolution in transport of the nineteenth century and role of railway "booms". For a general overview of the impact of technological change and the British Empire, see James Belich, Replenishing the Earth: The Settler Revolution and the Rise of the Anglo-World, 1783-1939 (Oxford: Oxford University Press, 2009), 107-114,228-229; Robert Kubicek, "British Expansion, Empire, and Technological Change," in The Oxford History of the British Empire: Volume III: The Nineteenth Century, ed. Andrew Porter (Oxford: Oxford University Press, 2001), 247-69.

${ }^{37}$ Fredrick Boileau Elliot, An Address on the Prospects of Railway Enterprise in Natal (Pietermaritzburg, South Africa: P. Davis \& Sons, 1864), 14.

${ }^{38}$ Ibid., 29.
} 
carrying out their duties by such an arrangement being affected." 39 Mayor Arbuckle, in his letter to the colonial government, alluded to a previous understanding that police constables would ride the railways for free. Recent changes on the government railways called this matter into question, prompting the mayor to confirm if precedent would be upheld, specifically the distribution of "free passes".

Though "Travel Expenses" had remained a critical component of colonial government, the amount provided for local police was perceived to be unacceptable with the changes in transportation within the colony. As late as 1869 , constables traveling between Pietermaritzburg and Durban would receive a per diem of five shillings, "a sum equal to the fare by public conveyance to be allowed to and fro, and [for] personal expenses whilst traveling or stationary at either place". ${ }^{40}$ Constables traveling on foot would receive nearly eight shillings and those on horseback one would be given 15 shillings. Comparatively, the heads of departments would receive 15 shillings for traveling via public transport and 25 shillings for traveling via horse. Though these expenses were viable alternative to the "free passes", the overall cost of such expenditures would only be done in the case of "specially authorised duty" and not when travel was a simple necessity for non-special occasions. ${ }^{41}$ It should also be notes that the disparity in expense was even greater when taking the "native" constables into consideration, who received only six pence when "traveling in charge of prisoners, or for the purpose of attending Branch Courts". ${ }^{42}$ The disparity in pay, however, remained a typical feature of the African employed within the colonial government. But despite this, the need to transition to a pass system for the local police was perceivably part of a general expansion of the police institutions within the colony as it continued to grow in the

\footnotetext{
${ }^{39}$ Minute Paper: Durban Corporation request that the Borough Police Constables may travel Free on the Railway, March 29, 1877, CSO 588, No. 1209, 1877.

${ }^{40}$ Memorandum Colonial Office Natal, August 17, 1869, CSO 589, No. 1309, 1877.

41 Ibid.

${ }^{42}$ Ibid.
} 
1870s. It was also indicative of the growing strain between the local and colonial governments, as the lines over jurisdiction began to blur and tensions grew over who exhibited full authority in Natal's growing urban centres.

\section{Local and Colonial Government Tension}

In April 1877, the mayor of Durban made another request to the colonial government. In this case, the request involved a grant of reserve land for the establishment of a house for the Durban superintendent of police placed "in as prominent a position as possible." 43 The reason for this request rested on the need to build directly between the present police station and the armoury stores near Market Square. Other property could not be made available because other land near the square was "required for market purposes." 44 It was also unfortunate for the Durban corporation that the police station rested directly on the border of the corporation and government land, with the armoury, controller of excise, and court house being within view, but not on the appropriate land that ran the length of West Street in the heart of Durban. ${ }^{45}$ The town council of Durban was very eager to begin building, even sending a follow up letter the following June indicating that council had already "accepted tenders for the erection of the building, and were anxious to have a reply from the Government". 46 Though illustrating the strong desire to have the building in a "central and convenient position", this restlessness from the town council "very desirous of setting the contractors to work without delay" illustrates not only the importance of this station to the Durban town council, but also acts as a prime example of the divisions of authority which

\footnotetext{
${ }^{43}$ Minute Paper: The Mayor of Durban- Requests that a piece of the reserve land at Durban may be granted on which to build a house for the Supt. of Police, CSO 592, No. 1616, 1877.

44 Ibid.

${ }^{45}$ An accompanied map also illustrated that the construction of the Superintendent's House would conflict with future building near the Market House, and would also result in the house being on the opposite end of the block from the police station, versus an adjacent building that was envisioned by Durban's local government. Ibid.

${ }^{46}$ Minute Papers: Mayor of Durban, June 28, 1877, CSO 592, No. 2421, 1877.
} 
existed in Natal at the close of the 1870 s as the urban centres began to drastically increase in size.

The colonial government's delay in responding to this request informs their overall opinion of the proposal. With the creation of the corporation system within Durban, the colonial government had the ability to exert less and less pressure on the growing urban centres. Though the practicality of proximity was a viable issue, it was rather dubious that the town council had proposed the construction of this house on the government side of West Street and not their own. This is evident in Surveyor General Peter Cormack Sutherland's recommendation that the land not be granted to the town council. In his report to the colonial government, he outlined the reasons why the reserve land was established in the laying out of the Town of Durban. One rested on Durban's place as not only a township but also the capital of the county. The other was simply the reserve of land for future purposes within the colony, including lands for the Ordinance and War Department as well as harbour, customs, and port departments. It was to the first point the surveyor general rested his apprehension with the proposal by the town council. ${ }^{47}$ Though the colonial engineer was cited as given multiple reasons "why this piece of ground should not be given up by the Government", it was the long history of gifting land to the town of Durban which gave Sutherland pause. Citing four occasions in the past decade where land was gifted to the corporation of Durban, including land for a jail in 1865, the Umgeni Railway line in 1864, the site of the local powder magazine in 1868 , and the site of a school in 1874. In all these cases, the construction projects were for the improvement of the township as the capital of the county. By simple semantics, the erection of a building for the local police department was not perceived as beneficial to the colonial government or the county as a whole and therefor prompting the request to be denied. Even if the land had not been set aside for later use by the colonial

${ }^{47}$ Surveyor General to Colonial Secretary, August 10, 1877, CSO 592, No. 1616, 1877. 
government, the local police of Durban were no longer connected to the interests of the areas outside of the township, despite the land's close proximity to the centre of town. Though the superintendent's house was presented by the mayor of Durban as "not only a great convenience in having the house contagious to the Police Station but an improvement to our most public thoroughfare", it did not meet the wishes of the colonial government, and was therefore denied. ${ }^{48}$

Despite the failure of the town of Durban to receive the land for improving their local police force, the consistent attempts to improve the local police force of Durban presumably influenced the thinking of the lieutenant-governor of the colony. In late April 1877, Lieutenant-Governor Bulwer issued a proclamation related to the police and constabulary in the colony. Bulwer's concern rested in the belief that some divisions and districts in the colony did "not adequately meet the police requirements of the districts." 49 This inadequacy laid in the lack of any general organization for the local police, with each force being essentially autonomous from the other in each magisterial division or district. Bulmer even went so far as to call the local constabulary not a "force" at all, especially in regards to their major functions of "serving summonses, in executing warrants, and in carrying out generally any orders given by the Magistrate." ${ }^{\circ 0}$ The lieutenant-governor even called into doubt the ability of the police to maintain any semblance of peace within the colony. To counteract this problem, Bulwer requested all resident magistrates to furnish a report on local police in their districts. Such reports would include the number and pay of the constables (both European and non-European), estimates of the population in the district, and the overall number of offences and summons which were issued from within that district. In essence, the lieutenant-

\footnotetext{
${ }^{48}$ Mr. Arbuckle, Mayor to the Colonial Secretary, P.M.Burg, 25 July 1877, CSO 592, No. 1616, 1877.

${ }^{49}$ Minute Paper: His Excellency the Lieut. Governor- Local District Police and Constabulary, April 25, 1877 , CSO 592, No. 1649, 1877.

${ }^{50}$ Ibid.
} 
governor was attempting to compile the opinions of the resident magistrate's in an attempt to rectify the problems that had plagued the police forces in Natal for decades. Nonetheless, he invited any recommendation related to "the strength, composition, and distribution of the Police of [the Magistrate's] district, and for its future organization, administration, and management, with a view to promote the efficiency of the force, and to provide for the prevention and detection of crime, or offences against the Laws." 51

Fifty copies of the message were sent out to the resident magistrates, with the exception of the Durban and Pietermaritzburg boroughs, and the administrator of native law with the markings of "Pressing". The additional request for a speedy response from the colonial secretary only emphasized the importance of this issue to the lieutenant-governor at the time. Reports from the magistrates of each district (which began to be published in the Natal Blue Books the previous year) offer an unclear summary of the matter of crime within the colony as a whole. The reports, in fact, offered little more than what was available in the yearly criminal statistics provided by the resident magistrates. Bulwer seemingly either ignored the fact that criminal statistics and yearly reports on crime by the attorney general had been available for several years, or he simply felt the information did not answer critical questions or provide any solutions to the growing concern for crime and violence within the colony. A special report was posted in the Natal Government Gazette in August of 1878, but the information included in this report offered only a few more details on cases and convictions before the resident magistrates. What the report did provide, however, was a yearly comparison for each of the magistracies from 1874 to the first six months of 1878 . The discrepancies between trials and convictions remained relatively consistent throughout most of this period despite the significant increase in the number of trials from 1874 to 1877 . The overall number of trials and convictions grew from 6012 to 8003 and 5223 to 6747

51 Ibid. 
respectively. ${ }^{52}$ No complete data on the number of constables in each of these districts were provided, showing the limited extent this data was able to alleviate any concern Bulwer may have had to the colony's maintenance of law and order.

The activity of the local constabulary was, however, not chiefly composed of exciting incidents or debates within the colonial government. Like most police work, the activities of the local constabulary were keeping the peace and preventing petty crime, as was a commonality within the colony. Whether the transportation or apprehension of escaped prisoners, the locating of stolen goods, or even local vandalism, the constabulary of Natal filled a need for the establishment of law and order within the colony. One such instance involved the illegal chopping of wood on government reserve by Africans in August 1871. Constable Thomas Green of the county of Durban witnessed multiple Africans chopping down trees near the railway. Though unsuccessful in his initial attempts to confront the axe caring men, the following day Green pursued one of the Africans to the house of a Mrs. Pullock. Green confronted the assailant, named "Kettle", and claimed that the sack he carried was the same sack found by the fallen tree the previous day, hence making "Kettle" culpable for destruction of government property. ${ }^{53}$ The court very quickly passed judgment on the word of the officer, despite "Kettle's" claim that he was making a fence for Mr. Pullock, and fined "Kettle" 40 shillings or face imprisonment for one month. To make matters worse for "Kettle" his axe was also confiscated by the Crown. ${ }^{54}$ If such an incident was fairly common, it does illustrate several factors. The European constable had in most cases the authority to make conclusions regarding the guilt or innocence of offenders and his testimony was typically damning enough to lead to a quick prosecution and sentencing. The European

52 "Legislative Council No. 25: Numerical Return of All Criminal Cases and Convictions from the Year 1874, 1875, 1876, 1877, and the First Six Months of the Year 1879", The Natal Government Gazette, August 20, 1877.

${ }^{53}$ In the Court of the Res. Magistrate County of Durban, $31^{\text {st }}$ August 1872, AGO I/8/14, No. 504A/1872.

${ }^{54}$ Ibid. 
constable also possessed considerable sway over the African population, especially in regarding their ability to apprehend and interrogate effectively. Perhaps more importance rested on the function the constabulary was beginning to fill by the beginning of the 1870 s, as this incident reveals. Unlike European institutions in the late $19^{\text {th }}$ century, where the concept of the "public" was something that was performed and that performance of political reason by the public was central to the operations of power within the state, the constabulary was forced to perform the actions of the public, instead of the population itself acting as surveillance on the "public" in European cities at the time. ${ }^{55}$ This could ostensibly be because of the presence of a scattered European population outside the urban centres of Natal, or simply due to the amorphous nature of the government and the people during this period. Either way, the presence of the constabulary fulfilled a distinct "public" need which ranged from stolen saddles to illegal woodcutting.

The growing tension within the colony in the aftermath of the Transvaal annexation and the impending Anglo-Zulu War presumably caused greater antagonism between the much criticized police force and the growing military presence within the colony. One such incident occurred in early 1878 , involving a local constable and an officer of the $80^{\text {th }}$ Regiment stationed in Newcastle. The incident originally stemmed from the capture and transport of a prisoner reported by Constable John Horne of the Newcastle magistracy, who had held the position since 1875. According to Horne's report, the constable was assisted in some manner by Lieutenant Griffin of the $80^{\text {th }}$ Regiment in the arrest of the prisoner Alfred Grug. Since a reward was offered for the capture of Grug, an insulting letter from Horne to Griffin revealed a dispute between the constable and the lieutenant. In this letter, Horne

\footnotetext{
${ }^{55}$ Sovereignties did implement institutions such as the police force as a type of technology of surveillance, but the concept of a "public sphere" of awareness is a strictly European sense seems to have not yet been established. Instead, it could be argued that "governmentality" (an apparatus for rendering reality thinkable in a way that allows for political programming) was only in its infancy during this period. See Patrick Joyce, The Rule of Freedom: Liberalism and the Modern City (London: Verso, 2003), 109,119.
} 
claimed "if the imperial government will not allow me my proper dues you can kindly keep the balance", implying Griffin was greedily demanding all parts of the reward. ${ }^{56}$

This was the interpretation of Griffin's commanding officer, Brevet Major C. Tucker, who forwarded the letter to the colonial secretary's office and demanded recompense for the “most insulting letter". Tucker's letter to the colonial government exhibits overwhelming shock that the constable "being an educated man...must have been aware of the gross insult he was offering to Lieut. Griffin". ${ }^{57}$ This letter was also forwarded to the Colonel Pearson, commander of Her Majesty's troops in Natal and the Transvaal, who also condemned the "impertinent" letter written by the constable. The colonel also casts full light on the level of insult by explaining (if it was not yet clear) that "the letter implies that a money reward which [Horne] claims has been unjustly withheld from him" and that "the constables conduct deserves reproof". ${ }^{58}$ Sadly for Constable Horne, no matter his intention, the letter to Lieutenant Griffin was presented to the colonial government as a grave insult to the honour of a member of Her Majesty’s Imperial Troops.

In Horne's response to the resident magistrate explaining his actions, the constable professed that in his mind the letter was not insulting or indented as such, but instead was attempting to address the reward he felt entitled to. Horne believed he was the one chiefly responsible for the apprehension of Grug, who was using an alias at the time which Horne was able to detect. The constable also firmly attested that his "complaints" were also in reference to not only the reward for capturing the prisoner, but also the per diem of 15 shillings for the horse used in finding and transporting the prisoner following his capture. ${ }^{59}$ Despite these claims, Horne was reprimanded by William Henry Beaumont, Resident

\footnotetext{
${ }^{56}$ John Horne to R. Griffin, January 30, 1878, CSO 630, No. 542, 1878.

${ }^{57}$ Brevet Major C. Tucker to the Colonial Secretary of Natal, February 5, 1878, CSO 630, No. 542, 1878.

${ }^{58}$ Colonel Pearson to the Colonial Secretary of Natal, February 10, 1878, CSO 630, No. 542, 1878.

59 John Horne to Resident Magistrate, March 5, 1878, CSO 630, No. 542, 1878.
} 
Magistrate of Newcastle. Ironically, Beaumont admitted that Horne did not intend to insult the lieutenant, though the letter "undoubtedly was" insulting. Beyond the reprimand, Horne was given caution "not to write any letter or have any communications which concerns his potion or duties as a public servant except through the Magistrate" ${ }^{60}$ Horne never recovered from this letter, at least in the eyes of the colonial government. Though still listed as constable at the conclusion 1878 , by November of the following year the position of European constable of Newcastle was now held by a Mr. G.W. Jones. Horne is not listed as holding government office anywhere within the colony. ${ }^{61}$ Though his removal from public life could not exclusively be attributed to his letter to Lieutenant Griffin, it presumably contributed to his eventual departure from public service. Horne's interaction with the imperial troops at Newcastle highlight the growing tension that existed within Natal during the build-up to the Anglo-Zulu War, but also clearly illustrate a hierarchy (whether official or perceived) which perpetuated the colony during this period. ${ }^{62}$ Similar to the use of mounted police as porters (see below), or the assignment of Africans from the police forces to the military, the police institutions of Natal, though perceived to be part of the overall defensive infrastructures of the colony as a whole, remained an underfunded, underappreciated pillar in Natal's growing identity. Though doubtlessly doing the best they could accomplish given the circumstances, the local police forces were simply underfunded, undermanned, and in several cases lacked the authority to move from one district to another or even have any mobility whatsoever. These problems, however, were nothing new, and were seemingly the major reason for other components of Natal's police structure to come into greater focus during the 1870s, including the Police Law of 1874.

\footnotetext{
${ }^{60}$ M. Beaumont, Resident Magistrate to Colonial Secretary, March 6, 1878, CSO 630, No. 542, 1878.

${ }^{61}$ There is no reference to Horne in any of the government establishments in 1879, and his position was filled by Jones on November 27, 1879. “The Establishment", Natal Blue Books, 1878-1879.

62 This growing concern was caused by a combination of tensions on the border related to the British annexation of the Transvaal, the disputes over land with the Transvaal and the Zululand, and the increased military presence within the colony by 1878 .
} 
One of the more important components of this Police Law, however, was the manner in which it provided more options for the residents of the colony of Natal. The police were an avenue for new employment, and the reform within Natal's police institutions highlighted the importance of such offices to those seeking employment, whether from within or outside the colony. There were opportunities in the colonial constabulary, and there was no lack of applicants for many of these positions. These applications would come to represent a unique case study in the hopes and limitations that permeated the colonial lifestyle, and illustrate the limitations both financially and socially that were present for many of the future and aspiring members of Natal's police institutions.

\section{The Hope of Application}

The appointment of constables, the questions of cost, and locating of effective applicants was relatively problematic during the 1870 s. Colonial costs collided with individuals vying for appointments, in many cases leaving positions within the constabulary, at least in the counties, vacant for extended periods. In the Ulundi Division, the position of European constable was never filled after the creation of the division in 1875 , despite the appointment of a resident magistrate. ${ }^{63}$ The position of European constable was eventually removed in 1877 , with the division being exclusively under six African constables. ${ }^{64}$ Cost, again, was a factor, as Ulundi could be paroled by six Africans for a total cost of $£ 74$ while a European constable would have cost $£ 84$ alone. Nonetheless, these vacancies were avenues through which members of the colonies white population saw opportunities to gain some semblance of service within the colonial government. Fluery P. Lightfoot applied for the position of European Constable for the Ulundi Division in 1875, with no clear example of his

\footnotetext{
${ }^{63}$ Though a gaoler was appointed to the division, but he soon departed from his position for personal reasons (See below)

64 There would be no European Constable stationed in the Ulundi Division even after the Anglo-Zulu War. "Civil Establishments", Natal Blue Books, 1875-1881.
} 
credentials, but only his willingness to take up the position or in "any other of the Magistraces [sic] requiring such services." ${ }^{\prime 65}$ Not surprisingly, Lightfoot did not receive an appointment to any position within the colonial government. Others also applied, including A.S. Woodgate, but with no success. ${ }^{66}$

Applications, however, were one of the many means through which the residents of the colony were able to make their case in taking part in the police institutions of Natal. The individuals who applied to such positions and the application process in general illustrates that the colony of Natal was becoming a viable location for colonial prosperity, allowing it to achieve some semblance of parody with other settler colonies like Australia, New Zealand, and Canada. The appeal of the colony seen in these applications is also illustrative of Natal's growing viability as a colonial entity. The hope that is exhibited in these applications exemplifies a growing trust in the colonial state, as well as the perceived benefits of taking part in the police institutions by members of Natal's European community.

In 1876, John West made his application to the position of constable for the newly created Ixopo Division. West seemed an ideal candidate for the position. His application was accompanied by letters from two previous employers, one being the Durban borough police. ${ }^{67}$ West, a 26 year resident of the colony, touted himself someone with an intimate knowledge of the area, and with many prominent associates within the town of Richmond, the largest in the division just south of Pietermaritzburg. West also put Arthur Hawkins, Resident Magistrate of the Upper Umkomanzi Division, as a reference and claimed him as an

\footnotetext{
${ }^{65}$ Fleury P. Lightfoot to Colonial Secretary, September 28, 1875, CSO 528, No. 2780, 1875.

${ }^{66}$ Minute Paper: Mr. A.S. Woodgate applies for office of Constable and Messenger to Res. Mag. Ulundi Div. September 29, 1875, CSO 529, No. 2805, 1875.

${ }^{67}$ Minute Papers: John West applies for the post of Constable of Ixopo or Richmond, February 23, 1876, CSO 545, No. 608, 1876.
} 
"acquaintance of a good number of years." ${ }^{68}$ Both letters of previous employment illustrated West's own experience in Natal, but also provide a deeper insight into the perceived expectations for the position. The letter from Horace Townsend, the Superintendent of Police in Durban, was almost five years old, but acknowledged West's service in the Durban police for two and a half years with his conduct being deemed "extremely good." No specific reference to his accomplishments, or the reasons for his leaving the force in 1871, are made clear, but West did not evidently go long without employment as his second letter of work came from Umzinto Lodge. Mr. M. Campbell, the estate manager, included in his letter that Mr. West had acted as a foreman for the estates for the past three years, with the letter dated December 1875. West was praised as a hardworking man who "manages the labourers well" while overseeing the field hands. Despite his hard work, West had been let go, ostensibly because of a shortage of labour on the estate. ${ }^{69}$ West, unemployed and looking for a more permanent position within the colony with the constabulary, applied less than two month following his termination from the estate.

Whereas West appeared to be a quality candidate and presumably expected to receive the post, he was one of at least four individuals who applied for the position of constable of the Ixopo. One was William Rose, who included no references and was an unlikely candidate for appointment. ${ }^{70}$ Another was G.W. Horden, another former law enforcement official. Horden had more recently arrived in Natal, but was a former member of the mounted police

\footnotetext{
68 Ibid.

${ }^{69}$ Copies of both letters are included with West's application under-Minute Papers: John West applies for the post of Constable of Ixopo or Richmond, February 23, 1876, CSO 545, No. 608, 1876.

${ }^{70}$ Minute Paper: William Rose applies for post of Constable of Ixopo, December 24, 1875, CSO 537, No. 3633, 1876.
} 
in Melbourne, Australia. He also had the claim of being the only candidate to actual reside in Ixopo at the time of his request. ${ }^{71}$

Despite the credentials of many of these candidates, the position would eventually be filled by Mr. Frederick James Jones in July 1876. Jones posting was not the result of extensive police experience, or even a previous posting within the colonial government, but instead seemed to be simply a case of knowing the right people. Jones claimed to be "well known throughout the Ixopo District" and provided at least two references to residents in that division. ${ }^{72}$ In his application, Jones also indicated he was encouraged to apply by the future Resident Magistrate of the Ixopo Division and acting Resident Magistrate of the Umgeni Division, Henry Cooke Campbell. Such claims of a personal relationship should not be overstated. When the colonial secretary asked is Campbell knew of this man who was applying, his response was "Personally I know nothing of him."73 Perhaps more striking is that despite the number of applicants to the position, Campbell had yet to even establish an office in the Ixopo and believed, at the moment, a constable was not required. By July, Jones was appointed to the post. The title of the new position in Ixopo was perhaps the most revealing component of this new position, as Jones was hired as the "European Constable and Keeper of the Prison".

The resident magistrates' yearly summary of the Ixopo Division in its first year stated that "very few criminal cases have come before me during my term of office." trend in Ixopo, the number of prisons in Natal had increased over the last decade, from eleven to fourteen between 1868 and 1876. Ixopo was listed amongst the gaols beginning with the

\footnotetext{
${ }^{71}$ Minute Paper: G.W. Horden applies for the post of Constable of the Ixopo, March 2, 1876, CSO 545, No. $681,1876$.

${ }^{72}$ Frederick James Jones to the Honorable Colonial Secretary, March 21, 1876, CSO 547, No. 846, 1876.

${ }^{73}$ Minute Paper: Frederick J. Jones applies for the post of Constable at Ixopo, CSO 547, No. 846, 1876.

74 "Reports of Resident Magistrates, 1876", Natal Blue Books, 1876.
} 
division's creation in 1876, but it would not actually house any prisoners until 1878, seemingly because a prison was not constructed until that time. Colonial planning, however, did not allow for the appointment of a new member of the constabulary who was not prepared for the eventual installation of the prison in the Ixopo Division. Frederick James Jones had much more administrative experience than the other candidates, which would be required in running a gaol. West had more practical experience in police matters, but Jones' previous employers and contacts included firms and commercial interests, including Gold Brothers and Gates and John Leask, Ferryman of the Upper Umkomanzi. ${ }^{75}$ The decision to decline West's application was not necessarily an indictment on his previous police experience, but instead could be an indication of the growing trend taking place in Natal's constabulary toward the conclusion of the 1870s: the rural police were becoming gaolers and administrators. This was particularly telling when Campbell responded to Jones' application by stating simply "He will then have to act as Messenger also." 76

Applications were also telling of the goals of many members of the colonial community, or the aspirations they held for themselves and their families. In 1876, Constable T. Peel resigned his position at Richmond as the European constable of the Upper Umkomanzi, a post he had held since 1861. John Johnson, Gaoler of the Ulundi, quickly submitted his application for the post. Unlike many other applicants, Johnson's reason for applying rested on the education of his children. ${ }^{77}$ As the constable post was in Richmond, Johnson believed that his children would have the opportunity to go to school and improve their education, something that was not perceived as possible from his posting to Ulundi. So important was this move, that Johnson expressed his willingness to return the $£ 10$ granted to him for travelling expenses on his appointment to his current post. George Ayliff, Resident

\footnotetext{
${ }^{75}$ Frederick James Jones to the Honorable Colonial Secretary, March 21, 1876, CSO 547, No. 846, 1876.

${ }^{76}$ Minute Paper: Frederick J. Jones applies for the post of Constable at Ixopo, CSO 547, No. 846, 1876.

${ }^{77}$ John Johnson, Gaoler Ulundi to the Honorable Colonial Secretary, June 23, 1876, CSO 555, No. $1610,1876$.
} 
Magistrate of the Upper Umkomanzi Division, had known Johnson, in his own words, "for a considerable period" and fully endorsed the move from one position to another within the colony. Johnson was required to repay the sum of $£ 5$, with the remainder being used for his transport to Richmond under his new position. ${ }^{78}$ This parallel movement in station within the Natal was not typical for many of the members of the Natal constabulary. Most would attain their post and remain there for decades (as was the case with Johnson's predecessor, Constable Peel), or leave the posting for opportunities typically outside the colonial government. This does not imply that advancement was not a goal for some members of the constabulary, especially as it continued to expand during the 1870 s.

The constabulary was not always the final position most members of the police hoped to attain within the colonial government. For many, it was the first step in more prominent positions within the colony and in theory propagated further advancement in Natal's growing colonial society. This, of course, was also exacerbated by the low pay European constables would receive. ${ }^{79}$ Such expectations were not unique to the colonial system in Natal, as similar situations developed in other parts of the Empire, including India. As Arnold has argued "a great many recruits, especially before the First World War, did not regard becoming a constable as a particularly desirable or worthy prospect, merely a means (and that often only temporary) of staving off unemployment, hunger, or even greater poverty." 80 The hope for advancement, however, was usually enough to encourage members of the constabulary to apply for promotion of other positions as soon as they opened. One constable from Durban, an H.M. Buchan, even attempted to apply to multiple positions in late 1877 . Buchan, who had

\footnotetext{
${ }^{78}$ John Johnson would hold the position for only another year, after which he disappears from government service. Minute Paper: Forwarding an application from John Johnson for the appointment of Constable in Richmond Magistracy, June 1876, CSO 555, No. 1610, 1876.

${ }^{79}$ These pay disparities have been previously discussed, with the European constables typically being the lowest paid Europeans within the colonial government.

${ }^{80}$ David Arnold, Police Power and Colonial Rule: Madras 1859-1947 (Delhi: Oxford University Press, 1986), 49.
} 
initially applied to the post of chief of water police, instead attempted to apply for the position of secretary to the harbour board. Buchan's reason for expanding his application was word that "several gentleman had made their claims" to the lieutenant-governor, and Buchan feared his "own application may therefore be unsuccessful." ${ }^{81}$ Buchan acknowledges that he had "some little experience in keeping minutes, and in the carrying out of Resolutions" which would make him adequate for the task. ${ }^{82}$ There is, however, no evidence that Buchan received either position, but his application is indicative of an attempt by members of the constabulary to increase their station within the colony, typically through a higher paid position which would instil a greater pay and prestige.

Even some newcomers to the colony with aspirations for police work were forced to reconsider their positions on arrival. Such was the case with Edward Frank Gregory, recently Captain of the $98^{\text {th }}$ Foot, who arrived in Natal in the early 1870 s seeking employment with the Durban constabulary. His letters of reference were extensive, illustrating his broad military experience in India, particularly the Punjab region. ${ }^{83}$ Unfortunately for Captain Gregory, his experience in India, which ranged from his time as ensign in November 1855 to at least the time of his appointment as captain in September 1862, did not favour his long term appointment to positions outside of military service. He had applied for the position of governor of the county prison of Perth, New Brunswick in 1869, which he failed to achieve. He did, however, seem to have at least some experience with law enforcement, as his application for chief constable of Durban included a letter from Major A.P. Miller, governor of the military prison in Dublin. Major Miller had met Gregory at Aldershot Camp in

\footnotetext{
${ }^{81}$ H.M Buchan applies for the appointment of Secretary to the Harbour Board, December 19, 1877, CSO 623, No. 4747, 1877.

${ }^{82}$ Ibid.

${ }^{83}$ Rawul Pindee and Muree are the two main locations his references originate, which included the Peshawur Division in India. List of Testimonials, \&c., in Favour of Capt. Edward Frank Gregory, Late $98^{\text {th }}$ Foot, CSO 554, No. 1587, 1876.
} 
Hampshire southwest of London while superintendent of the military prison, and was impressed by Gregory's knowledge required of an officer of law, claiming "I [Miller] had many opportunities of testing your [Gregory's] knowledge of the treatment of Prisoners and your ideas of repressing crime in England thoroughly coincided with my own." 84

Gregory’s knowledge of military law was also touted by Colonel W. Fullerton, Deputy Judge Advocate of the Bengal Staff Corps in Punjab. As with Major Miller's recommendation, this letter directly addressed Gregory's application to chief constable in 1873. Fullerton cited Gregory as a chief source of knowledge for not only military law and regulations, but also the criminal law of England, which was called upon on multiple civil cases, including felonies, which were tried by the military tribunals. ${ }^{85}$ Despite the qualification, Captain Gregory failed to attain the position of chief constable in Durban, and by June 1876, he was requesting an appointment in the excise department of the Colony. His only real qualifications for such an appointment rested on his claim that he had been "an active partner in a distillery in England" which had failed due to "advancing loans to Public Houses." 86 Whether or not Gregory received the position in the excise department is not as important as the road through which he arrived in Durban. From his letters, he seemed to have a fine, if not distinguished military career, and like many officers of the British Army, attempted to find work within the Empire following the conclusion of his service. Though having served only as an adjutant, his knowledge of the law was praised to at least some degree by the officers he communicated with. Ideally, Gregory saw his time in the military as his largest boon which would ensure his employment if not in England, somewhere within the Empire. Failing at a business at home, he first made attempts for employment in Canada,

84 Ibid.

${ }^{85}$ (Copy) Colonel W. Fullerton, Bengal Staff Corps, Deputy Judge Advocate, Sirhind Division, to E.F. Gregory, Esq., late $98^{\text {th }}$ Regiment, December 14, 1873, CSO 554, No. 1587, 1876.

${ }^{86}$ Minute Paper: Edward F. Gregory applies for an appointment in the Excise Department, June 19, 1876, CSO 554, No. 1587, 1876. 
and then Natal. The movement across the Empire that Gregory experienced was typical not only to members of the military, but also those working as part of the administrative structure of the Empire. ${ }^{87}$ Gregory, however, like so many others, met with failure after failure, despite what he believed to be his own extensive experience. This is an important component in the examination of the application process and the police institutions of the colony as a whole. Some saw their work in the police constabulary as stepping stone for greater things, others aspired to do what was best for themselves and their families, and even more looked at the constabulary as an opportunity to be a part of the colonial defence institutions, but fell short of achieving a place within the colonial government.

These applications, along with the aspirations and goals of the members of the constabulary, are indicative of perceived importance of the constabulary to the formation of a colonial state during this early period of Natal's history. The hope that is exhibited in these applications illustrates a growing trust in the colonial state, as well as its perceived viability for the members of Natal's European community. The belief that a role in the police institutions would change one's life in any shape or form shows the willingness of Natal's colonial community to take part in the defensive structures of the colony as a whole, without necessarily joining a social club for volunteers, or even a proto-militarized institution that would eventually come to replace many components of Natal's police institutions: the Natal Mounted Police.

\section{An Attempt at a Mounted Police Force}

By the 1860 s, some within the colonial government came to believe that the constabulary police force that had existed in the colony since its inception was becoming

\footnotetext{
${ }^{87}$ This transitory nature of "imperial careering" is clearly evident in the current historiography of the British Empire. See David Lambert and Alan Lester, eds., Colonial Lives Across the British Empire: Imperial Careering in the Long Nineteenth Century (Cambridge University Press, 2010).
} 
incapable of responding to growing needs of the colony. A simple constabulary was simply not enough for the proper administration of justice in Natal. In response to these concerns, some in the legislative council called for the creation of a mounted police force to act within the entirety of Natal. The law for the "organization and regulation of an Armed and Mounted Police Force" was seen by some as a measure to improve the law enforcement system of the colony as a whole. Enacted in August 1861, the law was established with the express purpose of creating a force to "act as police within or without the colony, for the preservation of peace, and preventing robberies and other crimes, and apprehending offenders against the peace." ${ }^{88}$ Unlike the constabulary, this mounted police force was a quasi-military organization which in theory used its mobility and military discipline to act not only as a force in keeping the peace, but also as a stop-gap for possible breaches in the police and defensive structures of the colony as a whole. The mounted force would not be limited to districts, counties, or divisions, but instead be fully capable of patrolling all segments of the colony when needed. More importantly, unlike the rural constabulary that was under the control of the resident magistrate of each district, the lieutenant-governor was the de facto head of this mounted force, able to make changes regarding enlistment, regulations, terms of service, uniforms, and the appointment of a commandant and officers. ${ }^{89}$ What the mounted police also represent is the willingness to try new forms of defensive institutions within the colony. Because of the demands for such a unit, as with the demands for other forms of security throughout the formative period, the mounted police's quasi-militaristic nature is another representation of the hybrid system created for Natal's defensive institutions, especially in regards to the police. Despite the extreme limitations and problems with the

\footnotetext{
${ }^{88}$ Law No. 15, 1861, "For the organization and regulation of an Armed and Mounted Police Force, and of an Armed Colonial Engineer Force of Sappers and Miners within the Colony of Natal", CO 180/2 (1861).

${ }^{89}$ The official position of commandant would not appear in the colonial records until the $1870 \mathrm{~s}$. It remained the lieutenant-governor's purgative to appoint such a member of the unit. The mounted police of the $1860 \mathrm{~s}$ were typically commanded by a captain. The ability to appoint a commandant would become more important with formal introduction of the Natal Mounted Police in 1874 (see below).
} 
unit, even shortly after its founding, the mounted police were still illustrative of the ever shifting concerns over security in the making of Natal.

In May 1863, Captain Albert Allison (later major in the Natal Carbineers during the Langalibalele incident) was given command of the unit, and would remain so until its eventual disbanding. These "mounted police" would have the ability to act as law enforcement officers throughout the colony, at the same time demonstrating a breadth of jurisdiction that was limited by other constabularies within the colony. Their goal was to "suppress all tumults, riots, affrays, or breaches of the peace, in any part where they may be on duty". 90

The organization and militaristic nature of the organization illustrates their perceived importance to the colony as a whole. Strict regulations were imposed on the mounted police in an attempt to create a more rigorous police institution. Those who took part in bribes, desertion, neglecting to execute warrants, or dereliction of duties would be harshly punished, in some cases receiving fines of $£ 20$ or facing six months imprisonment and hard labour. Taverns, pubs, or any “dealers in wines and spirits" were forbidden to harbour or entertain policemen of the force. Again, these officers were not above the law, and the formation of the force gave clear guidelines for how to bring about charges against members of the mounted force if they were to move outside the law in their duties. Of course, one would have to produce a written account of the events as well as proof within four months, and be able to convince the court of the wrongdoings of officers. Though typical, such regulation created strong limitations for any African wishing to submit complaints or charges against their

\footnotetext{
${ }^{90}$ Law No. 15, 1861, "For the organization and regulation of an Armed and Mounted Police Force, and of an Armed Colonial Engineer Force of Sappers and Miners within the Colony of Natal", CO 180/2 (1861).
} 
captors, especially when the mounted police were intended to work on the frontier where there were few witnesses to the contrary. ${ }^{91}$

A key point of inspiration for the mounted police system came in Natal from the Cape's Frontier Armed and Mounted Police under the command of Walter Currie in the Cape Colony. Formed in in June 1852 as the "Albany Mounted Police", the Frontier Armed and Mounted Police initially formed under a commando system of around 300 men, until they were reorganized under the sole command of Currie in 1855. Currie acted as sole commandant of the forces, with officers taking the title of inspector and sub-inspector. The mounted police's role was simple: to patrol and protect the districts in which they were stationed as well as the "clearing of 'thieves and marauders' from those districts." 92 Far removed from the Royal Irish Constabulary model of other parts of the British Empire, the Frontier Armed and Mounted Police represented a unique model that would come to its own by the latter half of the nineteenth century. ${ }^{93}$

By the 1860s, Currie's mounted police had gained wide recognition as the main model for a mounted police force within Southern Africa. Since the 1850s, the Frontier

\footnotetext{
${ }^{91}$ Though the use and abuse of power was not exclusively limited to white police, but instead was characteristic of the power dynamics imposed within the colonial setting. This has been more thoroughly examined in other parts of the Empire, especially Australia. See Mary Mackay, "Captors or Captives? The Australian Native Mounted Police," in Body Trade: Captivity, Cannibalism, and Colonialism in the Pacific (New York: Routledge, 2001), 47-65; Jonathan Richards, The Secret War: A History of Queensland's Native Police (St. Lucia, Queensland: University of Queensland Press, 2008).

${ }^{92}$ Edward Wilson, Reminiscences of a Frontier Armed \& Mounted Police Officer in South Africa (Grahamstown: C.T. Campbell, 1866), 186-188.

${ }^{93}$ The origins of the links between mounted police institutions and the Royal Irish Constabulary remains a heated debate within the historiography. Traditionally viewed as an evolution of the RIC model by historians such as William Morris, Richard Hawkins has called for a reassessment of the value of applying most non-civil police models with the manicure of decedents of the RIC, especially in regards to the mounted police across the Empire (based on the simple assessment that the RIC had no mounted forces of their own). Ironically, the Canadian Mounted Police postdate Currie's Mounted Police, though there are strong similarities between these "semi-military" forces during their early years, especially with the commissioned ranks of colonel, major, etc. See William R. Morrison's "Imposing the British way: the Canadian Mounted Police and the Klondike gold rush" and Richard Hawkins' "The 'Irish model' and the empire: a case for reassessment" in David Anderson and David Killingray, eds., Policing the Empire: Government, Authority, and Control, 1830-1940 (Manchester, UK; New York; New York: Manchester University Press, 1991), 18, 94.
} 
Armed and Mounted Police had acted as a major pillar of the Cape Frontier's security, as well as an instrumental force in the Pondoland. Currie had been particularly influential in the acquisition of the northern half of the Mpondo leader Faku's territory and its eventual distribution to Adam Kok's Griqua. ${ }^{94}$ It could, however, be argued that Currie's success against Faku with a small groups of armed Europeans was strikingly similar to the successes of Henry Francis Fynn or Commandant Pretorius of Natalia. ${ }^{95}$ Despite these caveats, to the colonial officials of Natal, the Frontier Armed and Mounted Police had over the ensuing decades been a consistent example of a positive, efficient police force in the Cape Colony and Southern Africa as a whole, with a reputation that attracted men far and wide.

The reputation of the unit by the 1860 s was so entrenched that they were able to attract member of the London Metropolitan Police, advertising in Bell's Life for "a few smart, steady, active Young Men." 96 The unit advertised itself as a rough and adventure filled organization that promoted from within and had opportunities for advancement within South Africa. Walter Currie (who had attained a knighthood by 1860) was presented by recruiters as one of the "more straightforward" men in the Cape of Good Hope, with the colony itself offering "considerable advantages to steady, energetic men, and that after three years service in the Frontier Armed Mounted Police, [one] might with profit...engage in some kind of business." 97 With such enticements, the Frontier Armed and Mounted Police not only represented a model of defence and protection within the colony, but also embodied a key

\footnotetext{
${ }^{94}$ Such conflicts were typical in the Cape Frontier, as outlined in Chapter Two. Currie's involvement in these incidents illustrates both a temporal and geographic proximity to Natal that likely influenced the perceived need for a mounted police force by the members of the Natal government.

${ }^{95}$ Faku's role in Natal's history will be more directly addressed in Chapter Six. Stapleton argues that Currie's success was a combination of his reputation, particularly involving the invasion of the Gcalekaland in 1858, with Faku's old age and possible vulnerability to extortion. See Timothy Joseph Stapleton, Faku: Rulership and Colonialism in the Mpondo Kingdom (c. 1780-1867) (Waterloo, Ont.: Wilfrid Laurier Univ. Press, 2001), 126.

${ }^{96}$ Edward Wilson being a prime example, who joined the Frontier Armed and Mounted Police in 1860, worked under William Currie, served for three years, and returned to England to become a detective. See Wilson, Reminiscences of a Frontier Armed \& Mounted Police Officer in South Africa, 1.

${ }^{97}$ Ibid., 3-4.
} 
principle of imperial expansion: the incentivisation of emigration from the Metropole. ${ }^{98}$ In so doing, the Cape Colony created a model that would not only influence the mounted police created in Natal during the 1860 s, but would intrinsically form the character of the Natal Mounted Police when it was reformed under Major John George Dartnell in the aftermath of the Langalibalele Incident of 1873.

If the legislative council of Natal believed in 1862 that "it is absolutely necessary that immediate steps be taken to establish a Mounted Police", Lieutenant-Governor Scott was less inclined to see a need for such a force: "I am not aware there is any urgent necessity for the establishment of such a force". ${ }^{99}$ Though Scott saw benefits of the framework of the Natal force working along the Cape model of mounted police forces, he expressed major doubts of its true necessity within the colony as a whole. Though he deferred to the legislative council in the eventual implementation of the law, his immediate concern rested on the benefit of such a force versus its cost. To fully implement the wishes of the council a unit numbering around 100 men would be formed. Scott immediately considered this infeasible considering the estimated cost of $£ 12,000$ this force would annually drain from colonial revenues. This number, according to Scott, was a "large sum for a young Colony now, for the first time...felling itself in a position to undertake public works of any magnitude". ${ }^{100}$ The only sensible reason for Scott's tentative approval of the law in his communication to the secretary of the colonies was in the inclusion of "an Armed Colonial Engineer Force of Sappers and Miners" in the law. ${ }^{101}$ This group, though technically attached to the mounted police and considered part of that force, would be required to serve under the government engineer in

\footnotetext{
${ }^{98}$ Such incentivisation was critical because of the disparity of emigration to South Africa in comparison to other parts of the British West. See Belich, Replenishing the Earth, 83-84.

99 "Despatch from Lieutenant-Governor Scott to the Secretary of State for the Colonies, on the Subject of Forming a Mounted Police Corps, and His Grace's Reply Thereto.” Document No. 35, NCP 4/1/1/2, 1862.

${ }^{100}$ Considering, the total cost to the colony for Police and Gaols in 1862 was $£ 1677$, the number was astronomical in comparison. "Expenditures", Natal Blue Books, 1862.

${ }^{101}$ Document No. 35, NCP 4/1/1/2, 1862.
} 
making roads, bridges, and on the construction of other public works when not performing the duty of police offices. In a colony that was just beginning to "undertake public works of any magnitude", Scott would be inclined to approve of these mobile engineering assistants. ${ }^{102}$ The size and cost of the force, however, would not meet the final approval of the lieutenantgovernor, and he forwarded his recommendations to Downing Street that the government should only purchase arms and equipment for about 25 men, "to be increased in number as the future finances of the Colony may allow." ${ }^{103}$ As head of the mounted force under the law, it was the lieutenant-governor's prerogative to the change the size and composition of the force in question. Downing Street approved, and a small mounted force would begin patrolling the colony by 1863 , at a more reasonable cost of $£ 3065$. Interestingly, despite this period being characteristic of a boom in the overall cost of police during the early 1860 s, the overall size and cost of the mounted police did not increase with colonial expenditures and revenues. Along with the mounted police, which reached its maximum cost of $£ 3,500$ in 1864, Pietermaritzburg and Durban both experienced a massive increase in police costs, beginning with $£ 900$ and $£ 1,200$ respectively in 1863 and growing to $£ 1,100$ and $£ 2,600$ in 1865. ${ }^{104}$ Scott's apprehension on the cost of these mounted police in comparison to the rest of the colony would be largely unfounded, as the unit rapidly declined in funding following 1865 until disappearing from colonial expenditures by 1870 . Ironically, the total cost for the mounted police in 1865 ( $£ 3322)$, exceeded the total cost of both the gaols and constabularies of all colonial counties that same year (£3212). This is even more glaring when one takes into consideration the county police and gaols employed 29 Europeans and 88 Africans, with the mounted police employing less than 50. Though the initial formation of the mounted force did demonstrate a failure within Natal's police institutions, their early formation in the 1860 s

\footnotetext{
102 Ibid.

${ }^{103}$ Document No. 35, NCP 4/1/1/2, 1862.

104 “Local Revenues", Natal Blue Books, 1863-1865.
} 
illustrate a growing concern in the mind of the elected officials in the colony over the problems of security and the force of law within the colony. Though somewhat unnecessary (at least in the mind of some government officials like Scott), there would continue to be a narrative within the colony that such a mounted force was imperative to the safety and security of the colony as a whole, despite the evidence to the contrary of the units overall benefit to the colony. Even by the conclusion of the decade, it would become quickly evident that problems of discipline, payment, and overall order were rampant within the unit, as became obvious when a large segment of the troops were summarily dismissed in 1866 . Ironically, the case against the members of the mounted police in 1866 clearly shows the manner in which the unit had already declined the later part of the $1860 \mathrm{~s}$.

\section{Thomas Joyce, Formerly of the Mounted Police v. The Colonial Secretary of Natal}

The mounted police represented more than a pillar of colonial security and the enforcement of law and order. Its costs to the colony was highly evident, but it also became an important component in the way Natal attempted to define itself during the colonial period. The success or failures of the mounted police during the 1860 s moved beyond revenues and expenditures, but also relied heavily on its fundamental purpose of providing an avenue for new immigrants to the colony. Much like the Frontier Mounted Police of the

Cape, the ability to attract men to the colony to become part of colonial society was a viable goal for such a force, especially as the colonial state continued to define itself during the formative period. By the mid-1860s, however, the mounted police were experiencing considerable turmoil from within its ranks in regards to promises made to its members and the opportunities it was intended to provide. This was only exacerbated in 1866 when at least 12 members of the unit were dismissed before their contracts were up, forcing these same members to sue to government of Natal for breach of contract. One such plaintiff was Thomas Joyce of England. 
Thomas Joyce from all appearances embodied the ideal member of the mounted police that the legislative council envisioned in the 1860 s. Joyce had served as a member of the metropolitan police in England for three years and three months until his arrival in Durban in May 1863. Like many members of this mounted unit, before even beginning his service, Joyce was already bound to the colonial secretary of the colony of Natal for $£ 50$ to "serve as a Policeman in the 'armed and mounted Police force' of the Colony of Natal."105 Like most contracts of the kind, this bond of obligation ensured Joyce's service (and employment) for a period of five years under the Law No. 15, 1861, and required Joyce to repay all sums advanced to him for the purchase of "House Saddlery, Uniform, Accoutrements, and other necessaries" during said five year service. Like Wilson of its Cape Colony counterpart, the Frontier Mounted Police, Joyce probably saw the opportunity for financial gain as well as the chance to start fresh in Africa. Joyce was personally recruited by Captain Allison in England and signed his contract in May 1863. He was soon posted to the "Olivier's Hoek" station along the Drakensberg range. Less than three years later, Joyce was out of the unit and suing the government of Natal for wrongful termination.

On the March 20, 1866, Joyce and 11 other members of the mounted police were reported absent from their duties without leave until the $27^{\text {th }}$ of March. According to the charges brought before the court by Sergeant John Knowlson, on the morning of the $20^{\text {th }}, 12$ men stationed at Olivier's Hoek led by Corporal Joyce left the station and moved toward the direction of Pietermaritzburg. According to Knowlson, there was great disaffection in the camp and the troops had talked of leaving as a body because of their grievances. Knowlson claimed to take no notice as he was "pretty well used to such talk", but he was surprised when the next morning they had "according to their word all left except myself and Sergt.

105 “J. Joyce v. Colonial Secretary of the Colony of Natal”, RSC 1/5/1867 (1081/1866). 
Robinson and took their troop horse in direction of P.M.s [Pietermaritzburg]." ${ }^{106}$ The event may have had relatively little notice if it hadn't been for the arrival of Theophilus Shepstone, who was seemingly surprised the station was manned by only two troopers. Shepstone's presence not only accelerated the troop's dismissal, but also provided greater exposure of the case to the colonial government. The troops' trip to Pietermaritzburg, however, was not permanent desertion, as all members of the troop returned on the $28^{\text {th }}$. So the question remained: why did they leave?

For all the men involved, once interviewed, they had left over a strikingly typical reason: money. On being interviewed following their return, all men involved claimed that they had left for Pietermaritzburg to "get paid", specifically to collect three months' worth of pay they had not yet received as well as their share of the police fund. Only Corporal Joyce offered any additional reason: pay and at the same time discharge, if possible, from the mounted police.

If would be particularly difficult to hypothesize the exact series of events which led to these 12 men disserting their posts for a week, seeking pay they viewed due to them. Joyce, along with Frederick Albert Abrahams, was the only non-commissioned officer amongst the group. At least four of the men (likely more) were from England and joined the mounted police at the same juncture in May $1863 .{ }^{107}$ In his statement to the court, Joyce claimed to have been granted the permission of Sgt. Knowlson to take ten men to Pietermaritzburg to submit a formal complaint to the colonial office that the troops had not been paid for three months and 20 days and had not received their percentage of the fines for the capture of criminals for their near three years of service. The men left in the morning, leaving their firearms at the camp as was custom when on leave, and returned a week later after visiting

\footnotetext{
106 Ibid.

${ }^{107}$ This is evident from the contracts available connected to the case. See RSC 1/5/1867 and RSC 1/5/1868.
} 
town. On arriving at the post and after a brief inquiry in April, Captain Allison summarily dismissed all 12 men from the force, citing the mounted police law in which "it shall be lawful for the commandant...to suspend, or dismiss from his employment, any such policeman, whom he shall think remiss or negligent in the execution of his duty". ${ }^{108}$ Equipment was returned and most of the men returned to either Pietermaritzburg or Durban. The matter, which on the surface appeared to be a simple case of reckless action and responsible discipline, seemed to be closed.

On May 16, 1863, proceedings of claims and demand were filed against the Colonial Secretary of Natal, David Erskine, by Thomas Joyce and his fellow former members of the mounted police. ${ }^{109}$ David Buchanan was appointed Joyce's attorney, and claims for recovery were put forward. ${ }^{110}$ The claims demanded three items: $£ 814 \mathrm{~s}$. for pay for the month of April in which the members served, $£ 25$ for the share of fines that were due, $£ 2519$ s. in return for sums paid for horse and accoutrements, and finally, £250 for "damages accruing...for unjust dismissal from said Natal Mounted Police Force."111

It was this percentage of the fines that create perhaps the most interesting component of this case. Joyce argued that an agreement was made between Captain Allison and the rest of the unit with the understanding that they would receive their due percentage of the fines procured by the mounted police for capturing criminals. Under the law for the "organization and regulation of an Armed and Mounted Police Force" it was inferred that "all fines or penalties which may be recovered by virtue of this Law shall be given and paid, one-third to

${ }^{108}$ Law No. 15, 1861, "For the organization and regulation of an Armed and Mounted Police Force, and of an Armed Colonial Engineer Force of Sappers and Miners within the Colony of Natal", CO 180/2, 1861.

109 Though each former member of the mounted police filed claims against the government, the only trial records that exists in their near entirety is that of Thomas Joyce. Other information of the members are available, but not to the same extent. This is why the following section will focus on Joyce and his case against the colony of Natal.

${ }^{110}$ Buchanan was well known as the editor of the Natal Witness and provides the most public face to this trial.

${ }^{111}$ Summons in the Supreme Court of the Colony of Natal, "J. Joyce v. Colonial Secretary of the Colony of Natal", RSC 1/5/1867 (1081/1866). 
the informer or prosecutor, if demanded, and the residue...for the public use of the colony" and that "any policeman belonging to said force shall be entitled to the whole, or a proportion of any forfeiture, penalty, or seizure, under this Law". ${ }^{112}$ Such a component of the law creates a much more nuanced motivation for joining, or commanding, this mounted force during the 1860 s. Because the laws of the colony allowed for economic gain, the motivation of financial advantage could have easily influence the actions of the members of the mounted police and those who had sway over them.

Once charges were brought upon the colony, it soon became clear that this trial would call into question critical elements of the mounted police institution. Joyce's statements at the trial exhibited the frustration and disappointment he felt in leaving his position in the metropolitan police, and lamented that he "should not have left England if I had not thought that I should be returned at the Government expense." 113 Such grounds were indicative of the "damages" that Joyce felt he had been given due to his early dismissal from the unit. Joyce's criticism of his commanding officer, however, cast greater light on his frustration with the unit.

According to Joyce, Captain Allison had previously told the unit that fines to the amount of $£ 100$ had been accumulated for the unit from the magistrate at Richmond, and that said funds would be available to the troops under the law for the mounted police. ${ }^{114}$ This was on top of the fines that had been collected by the unit in 1863 through 1865, again all moneys that should have been distributed to the men. Though these fines generated by the local

${ }^{112}$ A copy of the law is also included in the case file: Law No. 15, 1861, "For the organization and regulation of an Armed and Mounted Police Force, and of an Armed Colonial Engineer Force of Sappers and Miners within the Colony of Natal", CO 180/2, 1861.

113 “J. Joyce v. Colonial Secretary of the Colony of Natal”, RSC 1/5/1867 (1081/1866).

${ }^{114}$ According to revenue reports, the division courts of Newcastle did generate $£ 1358 \mathrm{~s}$. $6 \mathrm{~d}$. in fines in 1866 , as well as $£ 252$ in $1865, £ 180$ in 1864 , and $£ 43$ in 1863 . There is little evidence to indicate how much of these fines were because of the mounted police. "Revenues and Expenditures", Natal Blue Books, 1863-1866. 
magistrates would not entirely go to the mounted police, it would still appear to a member of the mounted police, especially when informed so by his commanding officer, that some amount would come to them in the near future. According to Joyce, those payments never came.

Joyce summarily argued that he had permission to leave the camp with his fellows and that the only reason Sergeant Knowlson had not accompanied them was because of Captain Allison's absence (placing the sergeant in command of the station). Such statements were corroborated by witnesses for the plaintiff, including Albert Thomas Stent, a private in the mounded force who joined the police at the same time as Joyce from England. Stent testified that it was justified for the men to go to Pietermaritzburg because of their overall lack of pay, and that the dismissal was unjust. Stent also gives a clear example of the type of individuals who came from England to join the mounted police. A former army man of three years, Stent's testimony was outright critical of the captain and sergeant, calling Knowlson a liar and implying that this incident would not have occurred if Allison had simply brought their pay. Stent's argued that this remained unusual to him as he had "never known Capt. Allison come back without bringing some money when he had been in town."115

For the defence, their main witnesses were these two individuals whose veracity had been challenged by Stent. Knowlson denied giving Joyce and the men permission to leave, claiming to "have no power to give them leave that I was aware of." 116 It was Knowlson who initially interviewed the unit after their return, and was the key witness in the evidence given for the dismissal, as none of the men explained themselves directly to Captain Allison on his return to the camp. Captain Allison's statements at the trail were also quite straight forward. He claimed that the men had not defended themselves when inquiries were initially made and

115 “J. Joyce v. Colonial Secretary of the Colony of Natal”, RSC 1/5/1867 (1081/1866). 116 Ibid. 
that, in his opinion, the defence of permission granted by Knowlson was insufficient to any effect. Allison also testified that he wrote and delivered the dismissal on April 25, 1866 and, quite simply, appeared to have no sympathy over the action.

In regards to the percentage of fines that had not been paid, Allison appeared to be more allusive. Allison argued that he did discuss with his men fines that would come out of Richmond but that only "certain fines" which had been levied along the Upper Umkomanzi would be obtained from the court, measuring only about $£ 80$. Allison argued that even if such money had been paid out to the mounted police, it would not have reached the $£ 25$ per man which was being requested. Allison retained his stance that "all fines awarded by Magistrates to the Force have been [moved] to [an] account in the Police Fund and divided amongst the men."117

Despite the best efforts of the defence, Joyce was able to present a convincing enough case to have the jury reach a verdict on his behalf. The jury ruled for Joyce and ordered $£ 200$ in damages to be awarded to Joyce, as well as reimbursement for the cost of the trail. The Joyce verdict gave credence to many of the charges being filled by his fellow commands, and resulted in a new series of trials for each member. Eleven trials were scheduled between November $9^{\text {th }}$ and $30^{\text {th }}$. Joyce was the most successful in his case, with some, including that of Charles Edward Graves resulting in a hung jury (five to two) and no verdict. Perhaps Joyce was simply lucky with his jury selection, or he was able to make the most convincing case due to his own experience in the Metropolitan Police. Either way, Joyce's victory is a representative of the fluid nature of law and order within the colony of Natal as well as the internal disputes that existed within the law enforcement system of the colony. Captain Allison would eventually move on from the mounted police to border patrol within the

117 “J. Joyce v. Colonial Secretary of the Colony of Natal”, RSC 1/5/1867 (1081/1866). 
colony and was not considered a candidate when the mounted police re-established itself in the 1870 s.

It should be noted that this mass dismissal of members of the mounted police could have acted as a key component in the eventual decline in the units viability as a whole in the 1860s. By the end of 1866, the expenditures for the mounted police had dropped from over $£ 3300$ to $£ 1,800$. That number would be halved by the end of 1867 (though Captain Allison still received $£ 192$ pounds in "travel expenses), and would be only $£ 100$ by $1868 .{ }^{118}$ Losing a dozen men of an already small force and obliging the government to pay $£ 200$ to one of its former members presumably crippled the institution for the next half decade.

\section{Shift after Langalibalele}

As with the volunteer organizations of Natal, the Langalibalele Rebellion acted as a major catalyst for the concerns over security within the colony of Natal. ${ }^{119}$ The failings of the established defensive systems to fully response to these perceived breaches of security prompted the colony to seek a clear alternative. Some within the colony had made their own recommendations to the defensive institutions through alternations to the volunteers. ${ }^{120} \mathrm{~A}$ popular idea, however, was the creation of a viable mounted police force within the colony.

An editorial in the Natal Mercury outlined the perceived need:

Let us have a thoroughly efficient Mounted Police Force... The experience we have gained during this late rebellion [Langalibalele's] has proved that the Volunteer Corps, be it ever so efficient, is not an arm that we ought to count upon expect in a

\footnotetext{
118“"Expenditures", Natal Blue Books, 1867, 1868.

119 The Langalibalele Rebellion of 1873 centred on the actions taken by Langalibalele, Chief of the Hlubi over the issue of firearms procession. John Macfarlane, resident magistrate at Estcourt, demanded in 1873 that Langalibalele, a powerful chief between the Bushman's and Little Thukela Rivers, ordered the chief to turn in all unregistered firearms under Natal's Gun Laws. The grievous action was Langalibalele's refusal to appear before Theophilus Shepstone.

${ }^{120}$ See Chapter Three: Volunteers, p. 77-87, for the accounts of Stainbank, "One of the People”, and Robson.
} 
great emergency and for a short period of service. It is ruinous to men in business or on farms to be kept in the field for months together. ${ }^{121}$

With Natal's limited white population, the creation of a mounted police force as a recruitment force as well as a major source of colonial security emboldened the legislative council to act following the Langalibalele incident of 1873 . To facilitate this need, a call for a new police commander was made, and answered by a John George Dartnell. A veteran of the Indian Rebellion, former Brevet Major of the $86^{\text {th }}$ Regiment who had served at the fortress of Jhansi in 1857, Dartnell had arrived in Natal in 1869 with the notion of becoming a farmer. Shortly after Dartnell's application was received, Lieutenant-Governor Pine personally requested Dartnell to raise a new mounted police force, saying "You probably know as much as any of the other applicants... and should at all events know something about discipline, having been in Her Majesty's Service." 122 Dartnell was a viable choice due to his reputation in India and his emphasis on proper discipline, a component that would serve in both his work with the police and the volunteers. The influence of the Cape system was also evident in this new police force. Dartnell would travel to King William's Town in the Cape Colony to familiarize himself with the organization and structure of the Frontier Armed and Mounted Police, apparently to initiate a more viable and accurate reproduction of the force than had previously been attempted in Natal. ${ }^{123}$ On his return, a call for members was posted to encourage able bodied men within the colony to act as its new defenders.

\footnotetext{
121 The Natal Mercury, January 10, 1874.

${ }^{122}$ Dartnell outlined this introduction in his forward to Holt's book on the subject of the mounted police. The modesty and simplicity of the statements could be misconstrued, but do indicate Dartnell's own modesty about the founding of the unit. There is also a strong sense of nostalgia in his writing as the Natal Police (formerly the Natal Mounted Police) were in the process of being absorbed into the South African Constabulary; in essence spelling the end of an era. See H. P. Holt, The Mounted Police of Natal (London : J. Murray, 1913), 4.

${ }^{123}$ W. J. Clarke, The N.M.P.: A Record of the Services of the Natal Mounted Police (Pietermaritzburg: Calvert, 1893), 6.
} 
By the start of 1874, in the shadow of the Langalibalele Incident, it became apparent to the colonial government that there was some necessity for reform within the colonial police system. 1874 saw the passage of the "Police Law", which centred on the establishment of "an organized Police Force." 124 This law was not an overarching reform bill of the police system, but instead the creation of a "special police force" for "the purpose of preserving order and repressing crime throughout the several Counties and Divisions of the Colony." 125 This group, which would eventually be formalized as the Natal Mounted Police, was only an extension on the established police institutions within the colony. The formation and organization of the mounted police, and this laws impact on the African police in Natal will be examined later, but it is indicative of the growing concern within the colony defining the expansion and use of police power in Natal and define their role in greater detail for the future.

The mounted police were included as the main focus of the 1874 police law and were provided their own set of clarified regulations outside of the normal police law. A collection of rules and regulations for "the guidance of the Mounted branch of the Police Force" was made available within the first six months of the new law taking effect. ${ }^{126}$ Though the vast majority of these regulations involved a clarification of the equipment and horses the police were responsible for, it is made perfectly clear that the "pay of the Officers and men will be made monthly" and that two shillings a month would be paid to the "Remount Fund", a type of insurance fund that would absorb the cost of lost horses and time lost for sickness or accidental injury. To ensure continuing service, men who quit the corps would "forfeit all

\footnotetext{
124 “Law No. 4, 1874: 'To establish an organized Police Force'," The Natal Government Gazette, January 20, 1874.

125 Ibid.

126 “Government Notice No. 148, 1874: Rules and Regulations”, The Natal Government Gazette, May 5, 1874.
} 
claim to share in any Corps Fund." 127 Additional rules and regulations were published the following August, again creating greater clarification to the matter of pay and equipment. Further clarifications on the conduct of the officers and the overall importance of their role in the colonial government were also made more emphatically. Incidences of "drunkenness, riotous conduct, disobedience of orders, or other misconduct" would be punished under the same standards of the Police Law of $1874 .{ }^{128}$ And to clarify that a position in the mounted police was not one of a volunteer or temporary service, the regulations stipulated that "No men of the Force to be employed on any other than public duty." 129 The necessity for such amendments was the by-product of initial problems with the mounted police, which experience considerable public criticism in its opening year.

Following such problems in establishing the mounted police the previous decade, the legislative council attempted to help redefine the parameters through which the unit was established in 1874 with the passage of the Law No. 5 in 1876 "To establish a European Mounted Police Force". ${ }^{130}$ The law was, in essence, a re-enactment of the previous law, with a few exceptions. A major change, fuelled by the apprehension over the number of African versus Europeans in the force, ensured that the force would consist of "not less than one hundred and fifty men of European descent... and of Natives of Africa and India not exceeding one hundred in number". ${ }^{131}$ Stipulations on the equipment of these two groups were also changed in which Europeans would be "armed and mounted" while Africans and Indians "may be armed and mounted as occasion may arise". ${ }^{132}$ Such changes were seemingly the residual effect of the Langalibalele incident only three years earlier, as well as

127 Ibid.

128 "Government Notice No. 254, 1874: Rules and Regulations for the guidance of the Mounted Branch of the Police Force," The Natal Government Gazette, August 4, 1874.

129 Ibid.

${ }^{130}$ Law No. 5, “To establish a European Mounted Police Force”, GH 1022, 1876.

131 Ibid.

132 Ibid. 
the long term residual impact of the Indian Mutiny. Though the Indian Mutiny and the

Morant Bay Rebellion had lessened British enthusiasm for indigenous troops, the

Langalibalele incident doubtlessly solidified these notions within Natal, continuing a legacy

of fear toward the indigenous population as a whole. ${ }^{133}$

In 1875, there were 94 members of European decent versus 150 "natives". ${ }^{134}$ On a matter of cost, such a system had great benefit for the colony. The 75 white privates in the unit were paid a total of $£ 5157$ while the 150 non-whites were paid a total of $£ 29615 \mathrm{~s}, 11 \mathrm{~d}$. For the colonists of Natal, however, cost did not necessarily trumps security and there remained apprehension in such a disparity of numbers between whites and non-whites in the most well-funded police institution within the colony. Still, the Natal Mounted Police offered another opportunity for the men of the colony of Natal to join a militaristic institution that was, in many ways, much more organized and to an extent disciplined than the volunteer institutions of the colony. This is largely evident in the rapid increase in European membership over its first few years of existence: 57 enrolled in 1874, 49 in 1875 and 1876, and 79 in $1877 .{ }^{135}$ This continued recruiting and cost saving measures allowed the mounted police to maintain their viability through this initial period of criticism.

With the establishment of the Natal Mounted Police, there was a sense of a greater formalization of the use of police within Natal, as had been previously seen with the regulation of the volunteers in the 1870 s. No longer would the colony tolerate a less formal

\footnotetext{
133 This fear of the armed African will be examined in greater detail over the next two chapters. For the legacy of the Indian Mutiny and the Morant Bay Rebellion, see Catherine Hall, Civilising Subjects: Colony and Metropole in the English Imagination, 1830-1867 (Chicago: University of Chicago Press, 2002), 243-264; Bolt, Victorian Attitudes to Race., 75-85, 205-215.

${ }^{134}$ Distinctions are not made between Africans and Indians, but it can be largely assumed that the vast majority of non-white troops were Africans, due in some part to the animosity that existed between Indians and Africans in Natal. "Expenditures", Natal Blue Books, 1875

135 This does not take into account the number of "natives" enrolled at that same time, but at least twenty eight were members of the unit by the end of 1874. "Nominal Roll: Natal Mounted Police and Natal Police", Killie Cambell Collection, Durban (1948).
} 
and perceivably inefficient force in the enforcement of law and order in the colony as a whole. Following the Langalibalele incident, the position of constable became more in line with maintaining the prisoner population and public order while traditional police work, or at least the focus on the criminal elements of the colony in its rural areas, were eventually left to the Natal Mounted Police as the organization continued to grow. In the end, the final outcome remained the same: local police forces were overridden or pushed out by a more centralized institution. ${ }^{136}$ With this in mind, Dartnell began to focus on the similar concern he had for the volunteer units of the colony: the proper maintenance of discipline.

\section{Discipline and Outcry}

Whereas the volunteers of Natal were not compulsorily required to attend or even submit to greater military discipline, at least in practice rather than principle, Dartnell was at an advantage when it came to membership in the Natal Mounted Police. This was the men's livelihood in the colony. If rules and regulations were not followed, they would be out of employment. It is no surprise than that disciplinary action in the mounted police significantly increased following the formation of the new unit in 1874, despite Dartnell describing years later the initial force being "amongst the flotsam and jetsam of the colony, and a very rough lot they proved to be, being principally old soldiers and sailors, transport riders, and social failures from home". ${ }^{137}$ Dartnell fondly remembering this initial group as "a very fine, hardy lot of men, ready to go anywhere and do anything, and very willing and cheerful if a little troublesome in town; but in the country, away from temptation, they were excellent men, who grumbles occasionally, of course, but were more inclined to laugh at and make light of

\footnotetext{
${ }^{136}$ Such conclusions are a consistent theme within police forces during the nineteenth century, including London. Andrew Harris argues that the increased regulation of police forces was a self-perpetuating cycle, in which the crime of the 1780s led to the more police forces which led to higher crime statistic, which led to greater concern for the size and formation of the police forces within the City. See Andrew T Harris, Policing the City: Crime and Legal Authority in London, 1780-1840 (Columbus: Ohio State University Press, 2004), $155-156$.

${ }^{137}$ Holt, The Mounted Police of Natal, 1.
} 
discomfort and hardship." ${ }^{138}$ Despite this overall positive memory, Dartnell's reminiscence does reveal initial hardships and problems with discipline that would have existed in any law enforcement group on the frontier. Dartnell strongly attempted to rectify these lapses in his first year of command.

Perhaps in response to the difficulties created in the late 1860s, Dartnell, as early as January 1874 , was certain to make clear with the auditor of the colony the method fines and punishments would be dispensed within his unit. In a response to the Minutes of the previous December on the infliction of fines by the resident magistrate of Weenen on members of the Police Force, Dartnell reaffirmed the authority of the commandant in instilling discipline, claiming that his position "has power to fine men, but it is occasionally necessary to inflict a heavier punishment upon a man in which case he is brought before the Res. Magistrate and imprisoned by him in addition to the fine" and in the absence of the commandant a noncommissioned officer could act in his stead in presenting the accused to the resident magistrate. ${ }^{139}$ Such gaps in the chain of command would not suffice in Dartnell's mind and repetitions of the Thomas Joyce incident of 1866 would be steadfastly avoided.

For Dartnell, this situation was not a hypothetical construction but instead a response to questions magistrates had over the new police force. In early January, a member of the force attempted to desert, was captured and sentenced by the Weenen magistrate to three months imprisonment and fine of $£ 5$. These sentences, though each listed as possible under the police law of 1874 , were immediately questioned by Dartnell, who informed the colonial secretary that "the crime of desertion for which this man was tried is only punishable by fine

\footnotetext{
138 Ibid. X-xi.

${ }^{139}$ Ironically, Dartnell, despite the air or being cooperative, was not completely devoid of attempting to stretch his new authority. Dartnell also claimed that such fines against the members of the mounted police would be submitted to the police fund, and not the colonial treasury, an interpretation that was quickly struck down by the auditor. Commandant Police to Auditor of Natal, January 2, 1874, CSO 503, No. 22, 1875.
} 
or imprisonment." 140 A warrant was eventually issued which dismissed the double

punishment. This early incident is indicative of Dartnell's awareness of the law, but also his

attempts not to become overzealous in the discipline he was attempting to maintain for his

"very fine, hardy lot of men."

Not all of these "fine men" were keen to the new parameters put forward by the commandant. In June, three members of the mounted police were reported to have stolen three horses and deserted to the Orange Free State. A warrant was issued for their arrest, but there is little evidence that they were ever captured. ${ }^{141}$ The reason for this desertion is unclear, but possible opportunities and closeness to the border was likely too tempting for any man who was not fully committed to police force. ${ }^{142}$ According to the unit's official history, there was "constant desertions, and nearly every month one or two were dismissed for misconduct, or as being physically unfit."143

Dartnell undoubtedly questioned the viability of the mounted police during this early period, as he had previously questioned the viability of the volunteer drills which were largely unsuccessful during his initial tenure as commandant. ${ }^{144}$ Some could perceive Dartnell's actions as one seeking to form a combined defence force within the colony, but instead, Dartnell's ideal defensive situation within the colony involved the combined efforts

\footnotetext{
${ }^{140}$ Commandant Police Force, Natal to Act. Colonial Secretary, January 8, 1875, CSO 504, No. 105, 1875.

${ }^{141}$ Minute Papers: Warrant issued by Act. Resident Magistrate, Ladysmith, for Apprehension in Orange Free State of three mounted policemen, charged with desertion and theft, June 15, 1875, CSO 519, No. 1834, 1875.

${ }^{142}$ Desertion was also a major problem in most frontier mounted police forces, including those in Australia. Reasons for desertion were many, including encouraged by relatives to return home shortly after joining, while others left after they found the job unpleasant and not what had been promised to them. Officers in central Queensland in particular had difficulty retaining full complements of their detachments, similar to Dartnell's concerns in the 1870s. Richards, The Secret War: A History of Queensland's Native Police, 162.

${ }^{143}$ Holt, The Mounted Police of Natal, 33.

${ }^{144}$ See previous chapter, in which Dartnell dismissed the stiff military guidelines of the volunteers claiming that "they would be no longer Volunteers except in name, but would be, to all intents and purposes, Militia, in which case every able-bodied man in the Colony should be obliged to join the force, or contribute directly to its support." See "Report of Commandant of Volunteers on the Volunteer Forces of the Colony," NCP 4/1/1/3, No. 112, 1874.
} 
of his two responsibilities. Again, the perceived hybridization of Natal's defensive institutions continued. Though the police force would ostensibly serve in the capacity of a police force, Dartnell wished to have "sufficient men in hand to nip an outbreak in the bud, or make a stand until the Volunteers could be called out" as Dartnell had full confidence the two forces could "work harmoniously together." 145 The Langalibalele incident still fresh in his mind, Dartnell's concern for a viable military force would be his focus for most of the remainder of this formative period. The commandant, however, faced a battle with not only supplies, men, and possible opponents, but also within the public sphere.

Though Dartnell in the early days of the mounted police attempted to instil a greater degree of discipline and military precision, criticism of the police seemed to be mounting even before any viable changes could have been made, especially from the city of Pietermaritzburg. In May 1874, the Natal Witness described a "feeling of antipathy" that was growing in the city toward the mounted police, specifically calling attention to "late disturbances...attributed to them."146 The editors claimed that Pietermaritzburg "was quite before they [the members of the mounted police] were enlisted, and has been much disturbed since". ${ }^{147}$ Though the no specific members of the mounted police, or even the institution itself, was charged, it was inferred by the paper's editors that "blame should rest upon that body." 148 The editorial license taken with these comments could easily be dismissed, but they do indicate at least some element of resentment within the press and in turn some elements of Natal's society. Such editorials were not outright negative toward the mounted police, but instead characterized a vane disappointment in the viability of the force during its first years.

\footnotetext{
${ }^{145}$ Letter from March, 1874 quoted in Clarke, The N.M.P., 7.

${ }^{146}$ Natal Witness, May 5, 1874.

147 Ibid.

148 Ibid.
} 
The lack of quality men was not damning evidence of the force's failures, but instead criticism that, whether true or simply exaggerated, influenced public opinion on the issue.

It was such instances which resulted in a perception of the mounted police as a group of unsavoury characters. In September 1874, reports surfaced that a group of police were acting in an unacceptable manner, including the stealing of oxen from the African population and "carousing at all the canteens along the road" in Alexandra County. ${ }^{149}$ So much of a scandal was caused by these actions that it was officially commented upon by the legislative council. Dartnell unequivocally denied such actions, provided letters from John Shepstone and his sub-inspectors to address the claims of ox theft, with Shepstone, then Acting Secretary of Native Affairs, issuing a statement claiming that the African reported that "a young ox had been voluntarily sold to the Police for the sum of forty shillings" and while the police had not the money at the time, they had made the payment before leaving the neighbourhood. ${ }^{150}$ As for the charge of public disorder, Dartnell demanded from SubInspector George Mansel of the police make full account of the accusations. In his report, Mansel claimed that the troops had stayed at a local store waiting for a supply cart to arrive. During that time, the troops did take part in the liquor that was available, but unlike the claims in the Witness, the police did settle their bill, and did not "demand" the liquor without payment. According the Mr. Chapman, the partner at the local store, there was "no drunkenness or carousing of any sort". ${ }^{151}$ In response to accusation about stealing food from a woman in Alexander County, Mansel did acknowledge talking to the woman, but claimed that she not only offered he and two of his men dinner, but also provided a ham and some

\footnotetext{
149 "Second Session, Seventh Council-1874, Legislative Council No. 8," The Natal Government Gazette, September 22, 1874.

150 “Copy: J.W. Shepstone to Major Dartnell, September 4, 1874," The Natal Government Gazette, September 22, 1874.

151 “Copy: George Mansel, Sub-Inspector to Major Dartnell, September 6, 1874," The Natal Government Gazette, September 22, 1874.
} 
fruit to the troops, claiming she said she "was very sorry you are all suffering so, but I have nothing more to give you." ${ }^{152}$ Such claims of ill treatment, were just one a few examples of the many instances of police misconduct which appeared in the Witness. From the killing of ox, to the stealing of goats, the mounted police were presented in the media not a lovable "rough and tumble lot" but instead a group of drunk bandits raiding the countryside.

The criticism in the Natal Witness was conceivably either exaggeration, or completely unfounded. As stated before, Dartnell expressed apprehension related to the quality of men he would be able to bring into the mounted police. The Witness was also acutely aware of this, describing it supremely difficult to "organize a Police Force with so little choice of men" especially in regards to the wages which were attribute to be "less than is earned by a kafir who can put a wagon on the road, and...no more than is given to steady kafir drivers and kafir skilled labourers." ${ }^{153}$ In truth, by the end of 1874, non-officers in the mounted police earned less than $£ 60$ a year. In comparison, a district European constable earned $£ 84$ a year, an usher for the legislative council earned $£ 75$ a year, and even a hospital matron or Indian constable earned $£ 60$. To compare the wages earned by the mounted police to African labour was an extreme, as most positions in both medical, legal, and police fields paid Africans an average of $£ 12 .{ }^{154}$ If the criticism of pay was not unfounded, the exaggeration of the press was most probably a point of contention within the command structure of the mounted police. William Clark in his account of the early years of the police outright declared a "prejudice displayed by a portion of the press... a prejudice that has been revived from time to time,

\footnotetext{
${ }^{152}$ Ibid.

${ }^{153}$ Ibid.

154 “The Establishments”, Natal Blue Books, 1874.
} 
sometimes for political reasons." 155 Even two decades after its founding, the "good name of the Force" was perceived to have been "blackened by the press." 156

All of this criticism took at least some level of toll of the mounted police and Dartnell. The criticism was exacerbated when in July of 1874 the mounted police were involved in an incident connected to Chief Umkwavuma who had challenged the local Magistrate's authority. With the temporal proximity to the Langalibalele incident, the colonial government dispatched 30 members of the mounted police, along with the commandant and secretary of native affairs. They were instructed to intimidate the chief into compliance with the colonial government. Whereas such an episode could have been a pivotal turning point to the facilitation of a positive attitude toward the mounted police, directly after leaving the Umzinto, the troop were accused of stealing meat from the Africans by a local missionary under the guise of "commandeering supplies". ${ }^{157}$ An official inquiry was established by the legislative council shortly after the incident. This resulted in the commandant's temporary resignation in December of 1874, which was quickly withdrawn.

Though this incident does exemplify both the difficulties and limitations of the mounted police, especially in regards to supplies, it also illustrates that the position of the police within the colony was increasing as early as late 1874. On hearing of Dartnell's resignation, the local press immediately lamented is impending departure, claiming to "honour making his acquaintance... [and] entertained the highest opinion of his fitness for the important offices he filled". ${ }^{158}$ In truth, the indictment of the mounted police in this instance was less of an attack on the institute itself and more of an attack on the government's lack of

\footnotetext{
${ }^{155}$ Clarke, The N.M.P., 7-8.

156 Ibid., 7-8.

157 “Legislative Council," The Natal Witness, September 25, 1874.

158 Taking into account Dartnell's other position as commandant of the volunteers. The Natal Witness, December 11, 1874.
} 
proper organization and maintenance, to the point when hearing of the Major's withdrawn resignation, the Witness praised Dartnell for showing he did not "intend to be kicked from pillar to post as is the practice under the present administration." ${ }^{159}$ Since the charges against the mounted police were eventually dropped, this incident possibly increased the positive image of the mounted police within the colony, especially when taken into account their overall success against Chief Umkwavuma before the incident of possible theft. The unit was even praised for succeeding where the resident magistrate had failed, emphasizing the fact "that the mere presence of 30 armed Mounted Police sufficed in an hour or two to enforce the neglected mandate, and without a blow being struck, to secure his [Umkwavuma's] punishment, speaks no less forcibly in favour of the value of the body that had been so heedlessly traduced." ${ }^{160}$ Despite the "negative press" following the accusation of theft, the attempted resignation of Dartnell and the actions of the mounted police in the security of the colony perhaps led to gradual acceptance toward the latter part of the decade, both in the press and from elements of the colonial government. It would not occur instantaneously, but would gradual build up until the Anglo-Zulu War, where, like most of the defensive institutions of the colony, it would be popularized and immortalized in myth and legend.

Even as late at 1877, the respectability of the Natal Mounted Police as a force was not assured. Despite some growth and success, the men of the mounted police were not always perceived as exclusive to their task of policing the colony. When a detachment of British troops were relocated to Newcastle, in response to impending annexation of the Transvaal by Theophilus Shepstone, they moved into the sphere of influence of a segment of the mounted

\footnotetext{
${ }^{159}$ Ibid.

${ }^{160}$ Such praise for the mounted police and criticism of their detractors is indicative of the internal debates which existed in the Natal press, fuelled by editorial interests and political and economic motivations for the colony as a whole. Times of Natal, September 26, 1874.
} 
police. ${ }^{161}$ Lieutenant Colonel Montgomery, in need of additional men, requested from his superior the retention of three men of the 25 mounted police stationed in at Newcastle. The labour they performed was "principally collecting supplies for the troops and...employed collecting bushels." 162 These three men, included two privates and a non-commissioned officer, would be at the disposal of the troops in Newcastle for as long as the mounted police were stationed there. No objections were raised by Major Dartnell as long as the men were permitted to return to their police duties when necessary. It is unclear if these three men were Africans, though it was unlikely that the non-commissioned officer was African, as there was typically only one African non-commissioned officer for the mounted police as a whole. ${ }^{163}$ Because the men of the police force acted as orderlies for Lt. Colonel Montgomery, it was probable these men were white. Whatever their race, the use of these men was indicative of the versatile and nebulous tasks that were sometimes performed by the members of the mounted police. Perhaps these men were necessary as a stopgap to the British military buildup that began in 1877 and would continue until well beyond the Anglo-Zulu War. More likely the members of the mounted police offered themselves as "warm bodies" in which the menial duties of the military presence in Newcastle did not have the manpower to spare. This incident does illustrate a cooperative element between these two pillars of colonial defence. Yet, the use of these men in a servile capacity could complicated the mounted police's the perceived placement in the defensive hierarchy. Despite the Natal Mounted Police's role as one of the few mobile defensive structures within the colony, they remained below Her Majesty's troops stationed at Fort Napier.

\footnotetext{
${ }^{161}$ For a more detailed account of the Transvaal annexation, see Guy, Theophilus Shepstone and the Forging of Natal, 473-474; Etherington, "The 'Shepstone System' in the Colony of Natal and Beyond the Borders," 185187.

${ }^{162}$ Minute Paper: Retention of Col. Montgomery of three members of the Mounted Police as orderlies, April 4, 1877, CSO 588, No. 1207, 1877.

163 Though the colonial records do not indicate the number of African non-commissioned officers in 1877 , previous listing had included only one non-commissioned officer for the twenty five "natives" in the unit. "Expenditures", Natal Blue Books, 1877.
} 


\section{Implementation and Use}

Even with these problems during its initial years, the Natal Mounted Police did remain an important component in the defence of the colony as a whole. Improvements were gradually made to the unit as funding would increase during the first years of its existence.

This did not mean that there were not considerable issues that remained. There were, however, a number of incidents throughout the 1870s building up to the Anglo-Zulu War that illustrate the mounted police's implementation and growing importance to Natal's defensive institutions. The Transvaal expedition, though the most well-known, was just one example of the mounted police's attempts to come to grips with the ever shifting colonial landscape during Natal's formative period.

Regardless of this seemingly positive trajectory, even by the start of 1875 , many units still lacked any permanent station outside of the headquarters that was constructed in Pietermaritzburg. During the especially cold and wet winters, this would cause considerable difficulty for the viability of the unit. Such was the observation of Dr. G.L. Bonnar, District Surgeon of the Umvoti when he communicated his concern in January 1875 . Two members of the mounted police stationed in Greytown were under his treatment, one suffering from a fever, the other with a chest cold and diarrhoea. Dr. Bonnar believed the cause of these maladies rested on the poor conditions the troopers slept, spending "the night in a dripping tent, wrapped in wet blankets," as the troopers described to the doctor. ${ }^{164}$ The doctor's solution to this hardship was rather simple: put a roof over their heads. Bonnar suggested that any type of room would be a major benefit to the force as a whole, not only for their health but for the viability of the mounted police as a whole. Bonnar advised a room should be rented or constructed to allow these men and others like them to recover. The only other

${ }^{164}$ G.L. Bonner, MD, Dist. Surg. Umvoti to Lieutenant Campbell, Sub-Inspector of Mounted Police, January 26, 1875, CSO 506, No. 399, 1875. 
alternative would be to transport them to a hospital in Pietermaritzburg. The doctor admitted that such poor conditions would perhaps "sow the seeds of disease in their constitutions, which may ultimately prove very serious." 165

Bonnar's apprehensions were forwarded to Major Dartnell, who moved to recommend the sick men stationed in Greytown immediately be bordered in a room for the next few months of the rainy season. ${ }^{166}$ Dartnell did not believe, however, that a construction project should take place, but instead the room should be rented only for those few month of the wet season. As for moving the men to Pietermaritzburg, Dartnell saw no need to have men sent to the city "for every trifling complication" but instead felt they were better "treated on the spot by the District Surgeon". ${ }^{167}$ Dartnell showed little sympathy for the other men, presumably a response to his own military training, stating: "The tents the men are now occupying in Greytown are good worth. All tents must be damp and uncomfortable...in wet weather. There is no hardship in men in strong health remaining under canvas." 168 Dartnell words provide a strong counterpoint to the sympathy and concern shown by Dr. Bonnar. Dartnell's concern for the sick troopers is relevant in his quick action, but his focus remained on the practicality of the situation. The Natal Mounted Police simply did not have the funds available for the construction of new building projects. Dartnell's total budget for the headquarters in Pietermaritzburg and the stations in Greytown, Estcourt, and Harding totalled $£ 1117$ 11s. 6d., an amount insufficient for the construction of permanent structures. ${ }^{169}$ Rent was a more practical alternative as the mounted police attempted to solidify themselves against possible threats to colonial security.

\footnotetext{
165 Ibid.

${ }^{166}$ Commandant Police to Act. Colonial Secretary, January 30, 1875, CSO 506, No. 399, 1875.

167 Ibid.

168 Ibid.

${ }^{169}$ Funds would remain low the following year, with only around $£ 900$ allocated to buildings expenses. "Expenditures", Natal Blue Books 1875-1876.
} 
Even when an actual threat did not appear, the mounted police would continue to be perceived by some members of the colony as a possible deterrent to crime. Such was the case in July 1875 when the resident magistrate of Alfred County requested the service of the "European Mounted Police" force, in response to possible smuggling in the district. Resident Magistrate J. Gilles, though confident that theft of stock was a rare occurrence in the district, had been privately informed that "guns and powder have been run or are being expected in Pondoland." ${ }^{170}$ Gilles believed that the mounted police would perhaps be more capable of searching wagons that were possible smuggling articles to "be taken or reaching our Griqualand border and passed through at night by Kaffir runners." ${ }^{\prime 71}$ Such a task would fall upon local law enforcement, but because of Alfred County's limited police resources, the Natal Mounted Police were a viable alternative. ${ }^{172}$ Gilles also had reservations about the use of "Kaffir detectives" because "as a rule Kaffirs are not to be depended on for night work" and in his opinion "the work would be better done by the European Mounted Police."173 With such praise, any reservation and debates that dominated the early existence of the Natal Mounted Police did not eliminate their growing perceived benefit to the colony as a whole.

In April of the same year, Resident Magistrate Osborn of Newcastle also requested the presence of the mounted police, however for perhaps more dangerous reasons. Sheepherders from the Orange Free State and the Transvaal had been moving across the border to winter their flocks in the Newcastle Division. Though not threatening on the surface, these same individuals were "often guilty of surreptitiously setting the grass on fire on private farms as well as on crown land in order to secure a supply of young herbage for

\footnotetext{
${ }^{170}$ Resident Magistrate, Alfred County to Hon. Colonial Secretary, July 31, 1875, CSO 523, No. $2250,1875$. 171 Ibid.

172 In 1875, Alfred County had one European constable and eight "Native Constable." These numbers are not strikingly less than other counties. Alfred also lacked a gaoler, so overseeing of prisoners would fall upon a greater percentage of the force. "Establishments: Police and Gaols", Natal Blue Books, 1875.

${ }^{173}$ Resident Magistrate, Alfred County to Hon. Colonial Secretary, July 31, 1875, CSO 523, No. $2250,1875$.
} 
their flocks to winter." ${ }^{174}$ Not only did this involve the destruction of land and property, but the dangers of the fires were exacerbated by their sometimes being set at night, seemingly to "enable the offender more easily to escape detection." 175 Osborn also lamented that he had limited numbers of police at his disposal. ${ }^{176}$ Again, however, his request illustrates the racial component of police action during this period by pointing out "these offences being perpetrated by white men, the difficulty of dealing with them by means of Native Police will be apparent to Government [sic.]." 177 Osborn's solution to these problems was the stationing of a contingent of mounted police in the division. Not only would stationing these men in the area curtail these sheep farmers, but would also be "of material aid in patrolling... especially along the extensive border of this Division, part of which lies along the Zulu Country."178 Osborn, in essence, was making a case for the role the mounted police could play in his division: that of a protective force for both domestic and foreign concerns within the colony; essentially, a border patrol. This was the purpose which the Natal Mounted Police force was envisioned by members of the legislative council and leaders within the colonial community as early as the initial attempts to create such a force in the 1860 s. Despite the emphasis on the division's importance to colonial security, Dartnell's response was more practical in nature, requesting that, because of the likelihood of horsesickness in the winter months in the northern sections of the colony, the resident magistrate should first provide accommodations for the half dozen man force he would send to the area. Though not the force envisioned by Osborn, these requests by resident magistrates for assistance does clearly illustrate the

\footnotetext{
${ }^{174}$ Resident Magistrate of Newcastle to the Honorable Col. Secretary, Natal, April 20, 1875, CSO 515, No. 1309, 1875.

175 Ibid.

${ }^{176}$ Newcastle, though in possession of a gaoler and one more "Native Constable", suffered similar difficulties to Alfred County in its overall police force. "Establishments: Police and Gaols", Natal Blue Books, 1875.

177 Resident Magistrate of Newcastle to the Honorable Col. Secretary, Natal, April 20, 1875, CSO 515, No. $1309,1875$.

178 Ibid.
} 
perceived need for the mounted police force within the colony and its approval in principle by some colonial officials.

A small caveat of both of these requests should not be overlooked. Gilles and Osborn were both ignoring the many Africans who were part of the mounted police; though the colonial secretary saw no issue in using African police as supplemental forces in apprehending the sheep farmers when responding to Osborn's request. In the colonial secretary's mind, the African police could just as easily identify who was responsible and report back to other officers. He did acknowledge, nonetheless, that African's ability to successfully apprehend white men was indeed an unlikely scenario. This contradiction in perception in relation to law and the racial divisions of the colony created a far more complex understanding of the manner in which police forces, both white and black, performed their duties within the colony. This racialized view of the police forces that many members of the Natal community experienced during the formative period will be more deeply analysed later in the next chapter.

As alluded to earlier, perhaps one of the more memorable, and somewhat acclaimed incident of the Natal Mounted Rifles before the Anglo-Zulu War was their expedition to the Transvaal. In September 1876, Theophilus Shepstone was appointed Special Commissioner of the Transvaal and was given instruction to mediate the disputes that were taking place between the South African Republic and the Zulu kingdom, though he was also given secret authority to annex the republic to Britain if it was perceived as feasible and favourable to the Afrikaners who lived in the Transvaal. ${ }^{179}$ Shepstone returned from London in December, and began formulating his contingent that would travel to the Transvaal. Before Shepstone's departure in late December, the executive council received a series of requests from

${ }^{179}$ Guy, Theophilus Shepstone and the Forging of Natal, 472-473. 
Shepstone which included "that a detachment of the N.M.P. [Natal Mounted Police] be placed at your [Shepstone's] disposal to as an agent during your mission to the Transvaal.".180

The choice of the mounted police is an intriguing one, but on further examination, the best in regards to the situation. Shepstone was not leading an invasion of the Transvaal (though his actions would eventually led to its annexation), so an official military escort would be unacceptable. The mounted police offered a quasi-military institution that could offer the same functions of a military escort. A mounted police force, however, would not cause the same level of concern amongst the Afrikaner population, though Afrikaner interaction with the mounted police in the border of Natal could instil at least some modicum of respect on their arrival. With this in mind, the Natal Mounted Police were fulfilling their ideal role envisioned on their formation: "act as police within or without the colony, for the preservation of peace". ${ }^{181}$ Of course, simple proximity could also have been a contributing factor. A detachment of mounted police under the command of Sub-Inspector Phillips was already stationed in Newcastle and would be available for the foreseeable future. Their proximity to the border, as well as their experience with the Afrikaners who they sometimes confronted, would be an adequate tool for the expedition. Whether out of outright need or convenience, the mounted police's inclusion in arguably one of the most important (if not infamous) diplomatic exhibitions of the 1870 s was a massive boon to the institutions exposure to the colony as a whole. ${ }^{182}$

\footnotetext{
${ }^{180}$ Minute Paper: The Commandant of Mounted Police- Report on his instructions, December 7, 1876, CSO 572, No. 1310, 1876.

${ }^{181}$ Law No. 15, 1861, "For the organization and regulation of an Armed and Mounted Police Force, and of an Armed Colonial Engineer Force of Sappers and Miners within the Colony of Natal”, CO 180/2, 1861.

182 The Transvaal Annexation, in the context of Natal's emergence as a colonial state, is particularly important not only to the development of the mounted police's role within Natal's defensive structures, but also an attempt to solidify Natal's borders, security, and, to an extent, identity. Natal, embodied in the persona of Shepstone, was emboldened to extend British influence into the Transvaal as an active benefit the Natal's role in the region. While the expedition resulted in eventual failure with the First South African War, the annexation remains an important point in Natal's emergence as colonial state. Though the mounted police were just one representation
} 
Major Dartnell was amicable in his instructions to provide troops for the expedition, but also possessed some apprehensions. Additional pay was the first point Dartnell confirmed with the executive council, as well an additional one pound per diem for wagons that would be necessary in the transportation of supplies. ${ }^{183}$ The wagons would be useful as well because, according to Dartnell, the Transvaal "is astonishingly unhealthy for horses, especially during the summer season, so it is possible that many of the horses belonging to men of the Escort will die." 184 The commandant also requested additional funds for this expected loss. ${ }^{185}$ When selected men for this expedition, the major had supreme confidence in the officers and men that would be stationed at Newcastle, claiming to be "careful in in selecting the men for this duty". ${ }^{186}$ Of the list of men selected, there was one officer (Phillips), one sergeant, two corporals, and twenty two privates, with the contingent of troops moving to the Transvaal consisting of nearly a quarter of the 108 white members of the mounted police. ${ }^{187}$ Dartnell assured the colonial government that he had "detached a steady Sergeant and other non-commissioned officers" and "had no reason to fear that these men will behave themselves in anyway bring discredit upon the Corps or the Colony." 188 Dartnell believed he could assure this result because none in the police force sent on the expedition appeared to be Africans, despite the force still containing 25 "native" members in 1876.

of this state, their presence shows the colony's willingness to become a viable player in the geopolitical conflicts of Southern Africa in the late nineteenth century. Such actions possibly even emboldened Natal to take a harsher stance on the Zulu which would directly contribute to the Anglo-Zulu War. These connections, though part of the general historiography, require perhaps further examination.

${ }^{183}$ Commandant Mt. Police to Colonial Secretary, December 7, 1876, CSO 572, No. 3310, 1876.

184 Ibid.

185 Though horse death was not rampant during the journey, on returning to Natal all but two horses stampeded, forcing much of the detachment to return to Newcastle on foot. See Holt, The Mounted Police of Natal, 38.

186 Commandant Mt. Police to Colonial Secretary, December 7, 1876, CSO 572, No. 3310, 1876.

187 The Shepstone Transvaal expedition was listed as a separate unit in the yearly reports. "Military", Natal Blue Books, 1876.

${ }^{188}$ Commandant Mt. Police to Colonial Secretary, December 7, 1876, CSO 572, No. 3310, 1876. 
The reason for this exclusion can be easily found in the commandant's assurances. This expedition represented a major diplomatic mission from the colony of Natal outside of the Zululand. The colony, in essence, was on display during this mission, and colonial leaders like Dartnell believed the enduring image of the Natal Mounted Police should not include an African face. This was even more relevant when considering the racial viewpoints of the largely Afrikaner population of the Transvaal. Again, apprehension about Afrikaner reactions to black troopers, as was the case in the border arsons, was a subtle component in Natal's perception of power and authority within the region.

Ironically, following the annexation of the Transvaal, the mounted police were still not seen as a forceful enough representation of the British Empire. They were hurriedly replaced by the $13^{\text {th }}$ Regiment which had been stationed in Pietermaritzburg, prompting the unit to return in April of 1877 . The mounted police did, however, create a positive impression on Shepstone, who forwarded a message from the newly established government house of Pretoria on the mounted police's departure. The office praised the police's efforts, thanked them for their "ready cheerfulness", and conveyed in "the highest sense...the manner in which [the police] discharged the duties of the officer commanding his escort." 189 Shepstone, as the new administrator of the government in Pretoria, requested that Phillips to express "the pleasure it has given him to observe their orderly and praiseworthy conduct, which has won them the good opinions of the inhabitants." ${ }^{190}$ Evidently Dartnell's assurance of proper behaviour was not unfounded.

The impression the mounted police made on Her Majesty's forces must have been a positive one, as another contingent of mounted police was requested in April 1877 to escort the troops from Newcastle to Pretoria. Shepstone was quick to point out to Major Dartnell

\footnotetext{
${ }^{189}$ Government House, Pretoria, May 28, 1877. Quoted in Holt, The Mounted Police of Natal, 37-38. ${ }^{190}$ Ibid., 38.
} 
that such an escort was unnecessary, presumably due to his belief that the situation in the Transvaal was stable. ${ }^{191}$ Dartnell did accompany the troops to the border, but returned to Natal with a smaller contingent as there appeared no need for the additional troops on the journey. Despite their rapid replacement when the situation in the Transvaal acceleration, the choice of bringing the Natal Mounted Police on the exhibition provided another example of their growing importance to colonial security, or at least the perception of that security, within Natal.

Despite their growing prestige and perceived importance to the Colony, even by the beginning of 1878 the colonial government still seemed unsure of the mounted police's purpose within Natal. One proposal put forward in January of 1878 would have the mounted police act as a currier express between Hancock's Drift on the Umzimkulu River and Pietermaritzburg. The purpose of such a proposal rested on the creation of a quick communication route with the border, especially as tensions heightened in the Transvaal and the Zulu Kingdom. Immediately, Major Dartnell questioned the practicality of such a proposal. Of the 12 men needed for such a system, all but the two stationed near Pietermaritzburg would be force to live at roadside public houses along the route, which would incur an unnecessary expense on the unit. Dartnell feared that the men stationed in public houses "would be subject to a poor many temptations... without proper supervision and [Dartnell was] afraid discipline would be relaxed." 192 Dartnell only saw such a system working if it modelled itself off of the Cape Mounted Rifles, in which men were stationed in parties of ten or twelve under non-commissioned officers some 20 miles apart. The major, however, still remembered that even in those cases "discipline was found to be lax." 193 It was

\footnotetext{
191 The Commandant, Natal Mounted Police: Correspondence related to the attachment of troops stationed at Newcastle accompanying the troops to Pretoria, April 14, 1877, CSO 590, No. 1455, 1877.

192 J. Dartnell, Major to Colonial Secretary of Natal, January 15, 1878, CSO 626, No. 181, 1878.

193 Ibid.
} 
even suggested that Africans could be employed in service of the express under contract to perform the task the mounted police were not willing to take up. ${ }^{194}$ Such a premise was not entirely beyond Dartnell's suggestions, since the Cape Mounted Rifles had at one point a significant African contingent, but the task was eventually given to Her Majesty's troops, who were a continually growing presence in the colony during the build-up to the Anglo-Zulu War.

Part of Dartnell's apprehension rested in the number of men in the mounted police needed for such a task on top of their typical duties. Such men were not readily available by the close of 1877 . The mounted police, as it continue to be a more important component of colonial defence during the build-up to the Anglo-Zulu War, numbered only 153 men, 25 of which were Africans. Dartnell, as has been previously stated, was never entirely satisfied with the state of his troops, and would make requests for additional recruiting from Britain (a tactic used extensively by the mounted police's Cape Colony counterpart). A call for 40 recruits in March 1877 had increased the unit's number, but more were required for the growing needs of the call. A call for 25 more recruits was made and approved by the Immigrations Department of Natal in January of $1878 .{ }^{195}$ Mr. Rolls, Emigration Agent for the Colony in London, was given clear instructions on the procedures of acquiring these men. The parameters put forward are indicative of the expectations that would shift the mounted police from a less regulated police unit to a full-fledged component of the defensive systems of the Colony of Natal. Speed was a critical factor in the orders given to Mr. Rolls, as well as the contractual obligations they would be forced to fall under upon joining the unit, which remained three years under the Police Law No. 5, 1876. Interestingly, health was also a major component of the recruitment process, were "recruits must be medically examined as to their

${ }^{194}$ Colonial Secretary to the Commander of the Troops, January 17, 1878, CSO 626, No. 181, 1878.

${ }^{195}$ Minute Paper: Enlistment of twenty five recruits in England for the Natal Mounted Police, February 1878, CSO 626, No. 194, 1878. 
fitness for service...particular care must be taken with regard to this examination". ${ }^{196}$

Evidently the diligence to health was the result of previous experience in which "a recruit of defective mental capacity was accepted on the former occasion and also a man who had lost a thumb." ${ }^{197}$ The physical and mental quality of the men was not unusual in the recruitment of colonial officials. The fact, however, that the agents could be selective with their recruitment was indicative of the growing professionalism of the unit, and, perhaps, to the growing perceived threats in the colony as a whole. ${ }^{198}$

\section{Conclusion}

Many of these incidents are indicative of an attempt by the reformed police force, both mounted and constabulary, to maintain and conceivably expand their influence over the ensuing decade. By the conclusion of the Anglo-Zulu War, the police force was a viable source of colonial security and was more or less capable of facing the many problems within the colony over the later part of the nineteenth century. This is in no way an attempt to create some kind of hero worship for these men, but instead a means to better understand their place in the formation of the colony of Natal. Though Dartnell remembered these men fondly decades later, it is evident that units like the mounted police were far from perfect, and faced their own issues of corruption, discipline, and scandal. However, because the force had both legal and financial backing, as well as the eventual support of the colonial government and population, it would foster itself as a critical pillar of the colony's development. The mounted police, both in the 1860 s and after their reestablishment in the 1870 s, were representative of the apprehension and concerns for security which defined this period. The European

\footnotetext{
${ }^{196}$ Major Graves, Act. Protector of Immigrants, Natal to Mr. G. Rolls, Esq., Immig. Agent for Natal, London, January 14, 1878, CSO 626, No. 194, 1878.

197 Ibid.

${ }^{198}$ Such perceived threats included those from outside the colony which propagated the creation of the volunteers, and those from within, such as the revolts of some chiefs in the 1850 s, 60s, and 70s. See Chapter Six: African Military Units.
} 
constabulary, whether urban or rural, though less inclined to receive the attention of colonial society, still acted as an important component in Natal's emerging defensive structures. Perhaps most importantly, the reliance on this two part system of policing demonstrates the need for a hybrid system of law and order. Without such a system, Natal's white police institutions would have conceivably followed a different route in the preservation of law and order within the colony.

Nevertheless, the white police institutions of the colony of Natal were only one, even a minor, component to the overall security of the colony. Though legislative action and public opinion drove the creation and reform of these European police forces, the primary source of colonial order was not the white European, but instead the African working under colonial authority. It is this group that shall now be discussed extensively, if only because of their critical role as key pillars of colonial security and in the formation of Natal as a colonial state. 


\section{Chapter Five: African Police}

\section{Introduction}

The European pillars of defence, with some exceptions, have been presented to this point as the primary defensive structures which defined Natal as in the early years as a colonial state in the nineteenth century. It was, however, the African who provided perhaps the most striking and vital element of colonial security during the formative period of the colony. These African institutions would take the form of the police and the military establishments that were directed by colonial administrators. Much like the white police and volunteer institutions of the colony, the African population was a component of colonial defence that elicited much debate, apprehension, and a sense of fear which permeated the colony in its early years. ${ }^{1}$ This chapter will address the importance of the African police to the creation of Natal's defensive institutions during the formative period, paying particular attention to the disparity that existed between the African and their European counterparts. Whether this included the issues of pay, their treatment by other members of Natal's community, or even their role in the preservation of law and order, the African police were representative of a unique form of colonial defence. By delving into the formation, organization, and responses to colonial violence the African experienced as a figure of authority within Natal, a deeper understanding of African agency in the formation of Natal as a colonial state will be revealed, indicative of a fluid state system of control that was

\footnotetext{
1 "African", as with the case of most of this dissertation, is being used as simplified shorthand for black people of African descent who occupied, whether originally or through migration, the colony of Natal during this period. The complexities of this question are too extensive to address here, but are analysed in recent scholarship by Guy, Lambert, and remain evident in the complexities of the mfecane debate. I have particularly attempted to avoid the generalized use of the term "Zulu", largely because of the amorphous nature and misuse of this tem during this period. Michael Mohoney's recent scholarship has facilitated new questions, especially in regards to the adoption of Zulu identity between elites and the lower classes, or a type of "Zulu-ization." See Michael R. Mahoney, The Other Zulus: The Spread of Zulu Ethnicity in Colonial South Africa (Durham, NC: Duke University Press Books, 2012), 1-5; Guy, Theophilus Shepstone and the Forging of Natal; Lambert, Betrayed Trust; Hamilton, The Mfecane Aftermath.
} 
characteristic of Natal. This will remain essential to understanding the imperial structures of defence that permeated the British Empire in the nineteenth century.

To accomplish this, the role of the African population must be examined in a more nuanced way. It must be remembered that without African participation, the formation of the British Empire in Africa would have been impossible. What remains more important, however, is addressing the question of why Africans participated in such institutions. ${ }^{2}$ The participation of Africans in police institutions has always been a complicated issue. Just like the interpretation of colonial police discussed in the previous chapter, there was no single system which permeated the Empire during this period, though generalities have been made. Since the traditional, European police model relied on a public consensus and general norms of behaviour, which did not necessarily initially exist in the colonial setting, modifications would need to be made which addressed the "lower levels of political and social development" and which spoke to the unique situations and cultures on the ground of colonial rule that did not exist in the City of London. ${ }^{3}$

The use of Africans as colonial police moved beyond simple convenience, and instead addressed a deeper physiological response to Empire by the British. For the African police and military institutions within the colony, the view of the African (particularly those associated with the Zulu) as a "martial race" was testament to both the optimism and apprehension that surrounded the establishment of police institutions during this formative period of the colony. On one hand, the British believed that the natural abilities of the

\footnotetext{
${ }^{2}$ This is the fundamental question that has begun to dominate the historiography, becoming the main subject of Parson and others work on black collaboration in Empire. See Timothy Parsons, "African Participation in the British Empire," in Black Experience and the Empire, ed. Philip D. Morgan and Sean Hawkins, The Oxford History of the British Empire Companion Series (Oxford: Oxford University Press, 2004), 257-285.

${ }^{3}$ This does not dismiss the cultural and social divisions in London during this period, but instead is an attempt to illustrate the strong divide between British law and order in Africa and the home front. See David Killingray and Anthony Clayton, Khaki and Blue: Military and Police in British Colonial Africa, Ohio University Center for International Studies Monographs in International Studies, Africa Series (Athens, Ohio: Ohio University, 1989), 5 .
} 
indigenous people made them suited to frontier defence, combined with the reputation of the "native forces" for being "fearless and determined fighters". ${ }^{4}$ Nonetheless, the arming of these "native police" and their acting independently would frustrate and terrify some members of the colonial population especially when confronted with colonial violence in their own homes and communities. ${ }^{5}$ Since the progression of the Natal police followed the general outlines suggested by Jeffries, the early phases of the colonial police depended on these African troops while at the same time retaining European officers and noncommissioned officers to keep such African forces "in line". 6

It would not be until long after the scope of this dissertation that Africans would attain any official position of authority within Natal's police institutions. Nevertheless, even Africans who submitted themselves completely as subordinates still retained some sense of agency and authority within the colonial government, even to some degree challenging the racial divisions that existed within the colony. Under such conditions, it would be more relevant to look at Africans and race as Kathleen Wilson sees it: "like gender and ethnicity, [race] was a historically contingent construction that did not describe empirical, static or absolute conditions in societies, but positional relationships made and unmade in historical circumstances and manipulated in the pursuit of power."7 Though such an interpretation would be dismissive of the massive work done on racial theory in Africa, it is helpful in the

\footnotetext{
${ }^{4}$ This is not unique to Natal, and can be seen in other areas of the Empire, including colonial Queensland. See Richards, The Secret War: A History of Queensland's Native Police, 120-121.

${ }^{5}$ Perhaps one of the most successful examinations of this juxtaposition comes from Heather Streets cultural analysis of the "martial race" theory. Streets shows that the "historically specific context in which martial race ideology became dominant was neither a 'metropolitan' nor an 'imperial' matter, but one that transcended both'. In so doing, Streets helps to emphasize the point that the perceptions of martial races in Natal were only a byproduct of imperial perceptions, illustrating a deeper connection between Natal and the Empire. See Heather Streets, Martial Races: The Military, Race and Masculinity in British Imperial Culture, 1857-1914 (Manchester, UK: Manchester University Press, 2011), 3.

${ }^{6}$ Jeffries contends that recruitment from the local population was only the first step in a general progression of the "Colonial people". Once these steps toward civilization had been made, including a general level of education and efficiency, would the appointment of local people to "superior grade" be approved by the colonial government. Jeffries, The Colonial Police, 32-33.

${ }^{7}$ Kathleen Wilson, The Island Race: Englishness, Empire and Gender in the Eighteenth Century (London ; New York: Routledge, 2002), 11.
} 
understanding of the African police as a component of colonial authority as well as an instrument of colonial oppression. Africans would never stop being Africans in the eyes of most European colonists, but providing them with positions of some authority made them a component of the growing colonial state. Perhaps it was this unseemly combination that caused such great concern from within some segments of the colonial population. It remains clear, however, that despite these misgivings, the African police in Natal remained a key component in the development of Natal during this formative period, despite debate, reservations, and even eliminations of segments of the force.

The level of overall success of these institutions in Natal was somewhat remarkable, considering these security forces were taken entirely from voluntary recruitment or encouragement from colonial officials, largely due to the fear of a potential African rebellion amongst the European population. This was not the case with all African defensive instructions in Natal, as some African military units were part of existing systems in which military service to the chiefs was compulsory. There is little evidence, however, that Africans in the police forces were pressed into service by colonial officials. Interestingly, these institutions were seen by some Africans as a benefit to the African people, perceived to some extent as part of a greater Westernization process. ${ }^{8}$ This hits at the heart of why African's took part in the police force and the greater security systems within the colony as a whole, but also provides a clear avenue to understanding the relationships between collaboration and resistance in the colony.

The manner in which African's resisted this colonial conquest has been a highly contentious issue within African history and the historiography of the topic as a whole. Like

\footnotetext{
${ }^{8}$ Such an interpretation is nothing new, shown in other examinations of colonial troops, including one African corporal in Rhodesia stating "when a native joins the Police Force he takes a step forward beyond all other Natives toward a higher standard of civilization." See Timothy Joseph Stapleton, African Police and Soldiers in Colonial Zimbabwe, 1923-80 (Rochester, NY: University of Rochester Press, 2011), 17.
} 
the rest of Africa, in Natal the police institutions were able to act as an avenue for collaboration, but to simply dismiss the Africans who took part in these institutions as colonial stooges would be to minimize their role in Natal's history. ${ }^{9}$ This has continued to be the case in Natal. As the apartheid era begins to fade in the historical memory of the Republic of South Africa, a more nuanced examinations of the role of early collaborators is paving the way for important research in the field of African history. ${ }^{10}$

The police model created in colonial Africa including in Natal, relied on a public consensus and general norms of behaviour, which did not initially exist in the colonial setting. Therefore modifications were made to the traditional British police model in the implementation of law and order within the colonial state. The imposition of a new and strange culture on the colonial population "would require the constabulary concept to strengthen, in particular, its capacity to contain unrest and keep order; the forces, therefore, would need to make provision for occasional deployments in gendarmerie and frontier military roles." 11 Alterations would also include forces falling under central authority instead of different local authorities. ${ }^{12}$ In Natal, the development of police institutions followed the basic model formulated by Charles Jefferies, moving from an "improvised arrangement" that included the Natal Native Police working under the direct authority of the Diplomatic Agent

\footnotetext{
${ }^{9}$ Perhaps the greatest contribution to recent historiography has been the acknowledgement that the resisters and collaborators were not that distinct from one another during the colonial conquest. See Ranger, "African Reaction to the Imposition of Colonial Rule in East and Central Africa"; Anthony G. Hopkins, An Economic History of West Africa (New York: Columbia University Press, 1973); Edward I. Steinhart, Conflict and Collaboration: The Kingdoms of Western Uganda, 1890-1907 (Princeton, N.J: Princeton University Press, 1977).

${ }^{10}$ Hlonipha Mokoena illustrates this historical trend that gives greater complexity to the notion of collaboration and resistance. According to Mokoena in her examination of kholwa intellectuals in Natal, some of these African's intellectuals work also harkened back to the Zulu kings of the Shaka era and praised the form of government as one to be imitated, illustrating a demand for nationalism, greater autonomy, and independent modernization. Such accounts did not mean a complete removal from the colonial system, but instead most likely was caused by the frustration that existed in the mind of these kholwa intellectuals under colonial rule. See Mokoena, Mugema Fuze, 207.

${ }^{11}$ Killingray and Clayton, Khaki and Blue, 5.

${ }^{12}$ Such was the case for Natal until the Corporations of Durban and Pietermaritzburg achieved full autonomy in their police force under Law No. 21, 1861 "For improving and consolidating the Laws in regard to Municipal Corporations", CO, No.180/2, 1861.
} 
for the Natives, Theophilus Shepstone, to a semi-military constabulary force, which would include the Natal Mounted Police, and finally a more civilian based force after the AngloZulu War. ${ }^{13}$ Within the towns and rural areas of the colony, however, the constabulary remained an amorphous force, working within the resident magistracy while also attaining some level of autonomy. The constabulary would consistently struggle with funding, man power, and criticism from both the colonial government and population. Therefore, as David Arnold would argue in his examination of Madras, the constabulary acted as a metaphor for the colonial regime as a whole, with the institutionalization enacting "the priorities and principles of colonial administration" as a whole. ${ }^{14}$ From their earliest creation by Shepstone in the later part of the 1840 s, these African police thoroughly enacted those same priorities and principles.

\section{The Natal Native Police}

After the establishment of an initial colonial government following the ceding of Natal from the Afrikaners in 1845, there remained considerable concern for security within early British Natal. While a contingent of the $45^{\text {th }}$ Regiment remained at Fort Napier and several Europeans began forming their own precursors to the volunteer corps, the issue of manpower was overwhelming. In the rural segments of Natal, the European population was incapable of regulating law and order, much less act in the case of an emergency. Yet, there remained an extensive African population that was beginning to fall under the sway of the emerging British administrative system. In early 1848 , to address the concerns for colonial security within the rural sections of the colony, a corps of African police was formed by Theophilus Shepstone under the recommendation of Governor Harry Smith of the Cape Colony in his proclamation of February 1848. As was the case with the European volunteers,

${ }^{13}$ This hybridization of the police force was emphasized in the previous chapter, and could easily be transferred to the African defensive institutions. Jeffries, The Colonial Police, 32-33.

${ }^{14}$ Arnold, Police Power and Colonial Rule: Madras 1859-1947, 2. 
security remained the great source of concern for these early colonial officials. Since

Shepstone had the greatest access to manpower as diplomatic agent to the African population, it was only reasonable that he would be placed in charge of such a force. His personal relationship with the local chiefs, as well as his place as one of the few administrators to consistently interact with the African population, gave him the greatest chance for the formation of such a police force.

Under Government Notice No. 32, Shepstone was named captain and James Melville and John Wesley Shepstone (Theophilus' brother) were named lieutenants of the Natal Native Police, formed "in prudence to the Proclamation of His Excellency Sir H.G.W. Smith, dated $10^{\text {th }}$ February 1848 ". ${ }^{15}$ Supplies were quickly requisitioned and notices were printed in the local press. Tenders for supplies on March 27 include 100 Woollen blankets, great coats, forage caps, and "good strong shirts—blue". ${ }^{16}$ According to John Shepstone, however, the uniform was white canvas suits, and they were not supplied with caps, though Shepstone recalled no particular difficulties to contend with in the formation of the corps. ${ }^{17}$ The corps would number 200 men, with only two white officers (Melville and John Shepstone). Strikingly, this early force was armed with the "Brown Bess" muzzle-loaders with bayonets, a remarkable deviation from later African corps. ${ }^{18}$

By May, the corps was being sent out across the colony in what would amount to typical police matters. John Shepstone marched from Pietermaritzburg on May $26^{\text {th }}$ "with 31

\footnotetext{
15 The Natal Witness, March 3, 1848.

${ }^{16}$ The size of the force presumably quickly increased from one hundred to two hundred men, since it unlikely Shepstone would allow his men to outnumber his supplies. The Natal Witness, March 27, 1848.

${ }^{17}$ The discrepancies in uniforms could be simply the recollection of John Shepstone in later oral interviews, which also included the number of men composing the force. See C. De B. Webb and J. B. Wright, eds., The James Stuart Archive Vol. 5: Of Recorded Oral Evidence Relating to the History of the Zulu and Neighboring Peoples (Pietermaritzburg: University Of KwaZulu-Natal Press, 2001), 297.

18 Though not uncommon during the conquest of Africa, Africans armed with firearms was a unique occurrence within Natal, whose government made major strides to keep firearms away from the indigenous population. Ibid., 294.
} 
men of the Native Police" to the houses of Ladsberg and Plessis at Doornkop which were found "broken open". ${ }^{19}$ This was part of a general tour of the colony from May to June, in which John Shepstone came into contact with both settlers and African kraals. No mention is made of the Native Police beyond their accompaniment of Shepstone, but was assumed they assisted in Shepstone fulfilment of his duties throughout this trip. Most of the crimes or disturbances reported were regarding the presence of Africans on land as squatters. By September, John Shepstone was stationed at the seat of the newly surveyed magistracy of the Klip River Division “with a party of Native Police", ${ }^{20}$

It should be noted at this point in Natal's history, there was only the $45^{\text {th }}$ Infantry and a small selection of the Cape Mounted Rifles which were involved in the protection of Natal from outside attacks. ${ }^{21}$ This was doubtlessly why the African corps were publically drilled every day by Sergeant Doyle of the $45^{\text {th }}$, not only because Doyle represented one of the few formal military institutions in the region, but also to alleviate concerns for the lack of discipline in this force from within the colonial population. ${ }^{22}$ As will be illustrated later, there were a number of scares that pervaded Natal which would eventually led to the formation of more institutions of colonial defence, including the volunteer corps and the mounted police. It remains telling, however, that this one company of African were ostensibly the only rural police institution for the first years of the colony's existence and on multiple occasions illustrated their prowess in the prevention and showing of imperial force. The unit, however, was not praised for their contributions, but instead the source of considerable debate. This was largely because it was assumed that that the funding for this police corps would come from the military, instead of the colony's budget. In essence, the troop was seen as a nearly

\footnotetext{
${ }^{19}$ The Natal Witness, June 30, 1848.

20 “Government Notice No. 87”, The Natal Witness, Sept. 29, 1848.

21 The Cape Mounted Rifles will be discussed later.

${ }^{22}$ Webb and Wright, The James Stuart Archive Vol. 5, 297.
} 
cost free addition to the colony's defence..$^{23}$ This assumption, largely unfounded, would eventually lead to the Native Police's eventual abolition.

As always, the issue of cost would continue to be a major imperative with the African police institutions. Though the Native Police was a relatively successful force, they were not a low cost expense for the colony. In 1850 , the Native Police cost $£ 2417$, with $£ 1254$ for pay and allowances to officers and another $£ 1122$ for provisions, clothing, etc. The remainder encompassed wagon hires, arms and ammunition, which was minimal, and medical expenses. ${ }^{24}$ Interestingly, there appeared to be a discrepancy in the public presentation of cost and what actually expenses was incurred. The Witness reported in 1853 that the cost of the police force in 1850 was $£ 622.12 \mathrm{~s} .2 \mathrm{~d}$ and the cost in 1851 (the year it disbanded) was $£ 59.18 \mathrm{~s} .3 \mathrm{~d}$. Total expense of the force after its disbanding was estimated at by the Witness at $£ 3076 .{ }^{25}$ Why does this discrepancy matter? This complaint about cost is continually cited in financial reports and legislative councils for years to come, and the disbanding of the Native Police is seen as a major cost saving initiative (with a reported cost of around $£ 3,000$ per annum). The perceived frivolous spending on the police remained a rallying cry against frugal spending for years to come within the colonial government.

This is presumably why there was little criticism, except from Shepstone, when the Natal Native Police were disbanded in April 1851 by Lieutenant-Governor Benjamin Pine. Pine saw the removal of the Native Police as simply a cost saving measure. Even within the legislative council there was a sense of relief that the Native Police would no longer be an issue. Walter Harding, Crown Prosecutor and Attorney General, even went as far as to say it

\footnotetext{
${ }^{23}$ The draw was understandable, considering Natal's "virtually non-existent budget" and the nature of military funding for the Imperial troops stationed in the colony coming from an independent fund. See Guy, Theophilus Shepstone and the Forging of Natal, 121.

24 "Military Expenditures", Natal Blue Books, 1850.

${ }^{25}$ The Natal Witness, February 25, 1853.
} 
ought to have been abolished three years prior, only a week after its establishment. Again, Harding's concerns seemed to be that of cost, as he objected to a percentage of taxes being used for a government officer that was not necessary, though Harding "quite appreciated Mr. Shepstone's services. ${ }^{\prime 26}$ Interestingly, despite these reservations on continuing colonial cost, the officers of the Native Police would receive pensions at half-pay, which James Melville would continue to collect well into the $1860 \mathrm{~s} .{ }^{27}$ The supplies and equipment of the Native Police were sold off piecemeal, including lockup houses and four pairs of handcuffs for each location. Ironically, Harding requested two guineas for use by the Pietermaritzburg local police, which was approved.

The reasons for the dismantling of the Native Police are not overtly complicated. The perceived cost savings that was initially proposed in its creation did not materialize, and the need for such a force, despite its successes, was considered widely unnecessary within the colony government. Also, the arrival of a new lieutenant-governor in Benjamin Pine led to extensive challenges to many of the systems that had been established by Shepstone, and the Native Police were just one component of these striking changes and tensions that permeated the relationship of these two key figures in Natal's early formation. ${ }^{28}$ Pine believed that greater discipline would be needed in the colony before Africans could be trusted with such important places in the colony's security. This could be seen in his later actions as governor of the Gold Coast in 1857, when he argued that the maintenance of law and order required an armed police force, "under strict military discipline", and subject to local government control. This was his response to the Gold Coast's attempt in 1845 to raise a small police force of 30

\footnotetext{
26 "Legislative Council, April 16th" The Natal Witness, April 18, 1851.

27 "Expenditures and Revenue", Natal Blue Books, 1860-1868.

${ }^{28}$ This will be further examined later in the tension created in the formation of indigenous levies to fight in the 1851 Xhosa War in the following chapter.
} 
or 50 men to be drilled and disciplined in the same manner as the London Police. ${ }^{29}$ Though no action was taken in the Gold Coast, dismissal of an African police system based on the London model was seemingly related to Pine's earlier experience in Natal and motivated his decision to dissolve the Natal Native Police in 1851.

There were colonists who challenged the loss of the Native Police, including Dr. Samuel Gower, District Surgeon for Pietermaritzburg, who, though reminding critical of the Native Police, admitted that "After-hand wisdom possesses great advantages for display." 30 Gower argued that although the Native Police were seen at the time of their dismissal as unpractical, he reminded colonists that "Sepoys [constituted] a large and efficient portion of the military strength of India [as] the native have merged into soldiers." ${ }^{31}$ Dr. Gower likely altered his opinion after the Indian Rebellion of 1857, but the sentiment remains clear. Even Thomas Phipson, who argued against arming Africans in levies for the Xhosa War, in a letter to the editor of the Witness, lamented the many problems within the colony during the early 1850s, including unpaid surveyors, bad roads, and the ill safety of life and property. He even included the disbanding of the Natal Native Police as a source of the colony's troubles, though it was said to be "the least loss certainly of the whole." 32

The termination of the Natal Native Police was an important point in the formation of Natal's defensive institutions. Though no evidence of being directly linked, the decline in the formalized Native Police and the increase in the volunteer movement cannot be ignored. While cost remained an important component of these decisions, the enthusiasm for white systems over black presumably had strong relations to the fear of rebellion. But it took time

\footnotetext{
${ }^{29}$ See David Killingray "Guarding the extending frontier: policing the Gold Coast, 1865-1913", Anderson and Killingray, Policing the Empire, 107.

${ }^{30}$ The Natal Witness, July 25, 1851.

31 Ibid.

32 “An Emigrant’s Letter Home”, The Natal Witness, May 9, 1851.
} 
for this fear of rebellion to be solidified, and such fear would continue to evolve during this formative period. It is important to understand the abolishment of the Natal Native Police was not the end of Africans acting as policemen within the colony of Natal; far from it. The limitation on manpower and the extended countryside called for an African population that would take an active role in the defence and maintenance of law and order within the colony. The continuing criticisms of Africans acting as police and constables, however, would expose a deeper apprehension and concern regarding Africans in positions of authority that moved beyond simple costs. The concerns for African instead of European police authority would be a continuing debate within the colony, and exposed the racialized concerns which saturated Natal during this formative period. Despite these concerns, the "native policeman" would remain an important pillar of colonial defence well after the Natal Native Police and continue to provide avenues for African agency as Natal continued to establish itself as a colonial state.

\section{"I was Witboy, of the police."}

As has been previously emphasized, African authority within the colonial police was an amorphous idea, related ostensibly to case by case instances that involved Africans exerting their authority over the colonial population. Although the traditional image of the African constable has been that of a subordinate to the white establishment, membership in the police systems did create some sense of entitlement amongst the African constabulary. Since the types of recruits typically seen within the Empire were a combination of former service men and indigenous support, the expectations of the African to rise above their station was somewhat marginalized. As Anderson and Killingray have emphasized, though indigenous constables tended to work in areas where the white population would generally police itself "it was a bold 'native' constable indeed who would, of his own initiative, have 
sought to police a member of the white ruling class." ${ }^{33}$ With Natal's limited resources, especially in urban areas, it was impossible to have exclusively white forms of police authority, precluding the white population from "policing itself" in the context of the diverse and competing interests pervading the developing urban centres of the colony.

Notwithstanding, the situation on the ground in Africa, and especially Natal, would always call upon a unique approach to the problems of crime and defence within the colony. These unique situations gave police greater power and authority than their London counterparts, especially the manner in which race offered different views of the idea of "social morality" and racial order within the colonial setting. ${ }^{34}$ Though notions of race and social morality, especially in regards to clothing and weapons, would typically be used against the indigenous population, when law was on the side of the African policeman, it was an effective weapon in his arsenal in the maintenance of colonial authority.

In December of 1860, a case was brought before the court in Pietermaritzburg over the possession of ten double-barrelled guns, near Fieldeu's Farm, in Pietermaritzburg. The defendant was a Joseph Harcourt, charged with the illegal selling of firearms in the colony without a proper permit. Such cases were typical in Natal for much of this period as the firearms legislation continued to be changed and altered by the colonial government. ${ }^{35}$ What made this case particularly unique, however, was the primary witness against Harcourt: the African constable Budaza, also known as "Witboy". ${ }^{36}$ The incident in question took place on November $16^{\text {th }}$ at Umkeyi's kraal outside of Richmond (near the hinterland of the Mlazi

\footnotetext{
33 This is a larger generalization for the Empire as a whole, but gives credence to the expectation that were held by many colonial communities. See David Anderson and David Killingray's "Consent, coercion and colonial control: policing the empire, 1830-1940" in Anderson and Killingray, Policing the Empire, 7.

${ }^{34}$ Anderson and Killingray link these ideas of "social morality" in the Cape Colony to the distribution and enforcement of liquor laws in the colony, but such morality could also apply to the righteousness of law in any colonial setting. See Ibid., 10-11.

${ }^{35}$ See below.

${ }^{36}$ The trial was reported in the Witness in a series of reports every two days over the last week of December, 1860. Budaza's account and cross examination take up the majority of the testimony. The Natal Witness, December 28, 1860.
} 
location). Budaza arrived at the kraal with the local European constable, William Watson, to check on the local chief, with Watson leaving shortly thereafter. Budaza, with four other African constables, heard the sound of dogs barking outside the kraal and upon investigating the noise, discovered two Africans with bundles in the shape of long sticks. Budaza felt the bundles and discerned they were guns. When asked by the Africans with the bundles what authority the constable had, Budaza responded: "The Magistrate's". This response did not seem enough for the Africans, who gained more confidence in the arrival of Harcourt who had been in another part of the kraal. Harcourt contended that only the magistrate had the authority to untie the parcels and not some African who claimed to be a constable. In his report to the court, Budaza stated "he [Harcourt] told me to go and bring the Magistrate to untie them. I asked him if he did not know that I was Witboy, of the police."37

This brash statement of authority was a testament to not only Budaza's confidence in his position, but also telling of the changes in relationship between race and authority that existed within Budaza's worldview. He was supremely confident in his authority as an officer of the law and almost boastful of the position it supplied him in the colonial system. In his deposition against Harcourt, Budaza defined himself as "the head of the native police at Richmond" though such a title did not exist within the colonial system. ${ }^{38}$ Budaza, in turn, had presented himself in a greater position than the colonial system would allow. Naturally, there would be some form of hierarchy that would develop for African constables in the field, especially in divisions that had no European constable, but Budaza's actions are more clearly evident of an attempt to gain greater authority within the colonial system. During cross examination at the trial, Budaza claimed he "had not the badge [of the constabulary] on my arm when I asked Mr. Harcourt whether he did not know that I was Witboy, the policeman"

37 The Natal Witness, December 30, 1860.

${ }^{38}$ Ibid. "Native Constables" for each district of division were listed in the colonial records as one group, without any command structure or officers. See "Establishments", Natal Blue Books. 
but insisted that Harcourt did know him from seeing him in Richmond and in the kraals around the area. ${ }^{39}$ Even without his official badge of office, Budaza was confident enough in his position to assert himself against a white man who was well known in the region.

Following Harcourt's demand, Budaza returned to the hut for "his sticks" (his assegai and knobkerrie), during which time the assailants fled, including Harcourt. Budaza was able to quickly catch Harcourt, who was now at the kraal with one of the bundles. Again, the African constable confronted his suspect and insisted that Harcourt identify the men who were with him as well as return with him to the European constable. Harcourt initially agreed and the two made their way to Richmond, with Budaza on foot and Harcourt on horseback. Harcourt, however, changed his mind and stated his intentions to return to his farm, resulting in a heated argument between the two. Finally, after threatening to "stab him with my [Budaza's] assegai” if he ran away, Harcourt agreed to accompany Budaza to Constable Watson and then the magistrate. There the bundles were untied, revealing ten guns, presumably to be sold to the Africans in the regions. At the trail, Harcourt was found guilty and forced to pay $£ 5$ for each of the ten guns in his possession. ${ }^{40}$ Perhaps most surprisingly, the primary evidence against Harcourt came from Budaza's testimony, which was corroborated by Watson and the magistrate. Though such incidences involving the direct arrest of a white man by a black man was somewhat uncommon within Natal during this period, its exceptionalism does not diminish the importance of Budaza's perceived role within the colonial hierarchy. The badge (when he wore it) denoted a position of authority that superseded race, to at least some degree, but more importantly, even without the badge Budaza insisted on his ability to be known and respected within the region, even when not in the direct presence of the European administrator who gave him his authority.

\footnotetext{
${ }^{39}$ The Natal Witness, December 28, 1860.

40 The Natal Witness, January 1, 1861.
} 
Ironically, there is little notice of the exceptionalism of this particular case in the press. Budaza was not presented as a unique case, or a "clever African". This is a marked difference between another incident in 1871, where an African constable, described sarcastically as a "Detective", fell for a piece of subterfuge by a horse thief and was mocked in the news. ${ }^{41}$ Committed, intelligent, and successful African police were rarely a feature in any public account. Budaza could be dismissed as simply a "bold native constable" who challenged a white man, but it could easily be argued that he instead represents an emerging sense of realization of authority that some African members of the colonial government developed during this formative period of Natal, laying the groundwork for future entitlement and perhaps entrenched collaboration. ${ }^{42}$ Budaza, while an exceptional case, was inherently characteristic of the attempts to gain agency, or at the very least authority, within Natal during its formative period. By emphasising and enforcing his perceived standing within the colonial state, he better defines the place of some Africans within the making of Natal. The boldness of this constable, however, especially his threat to stab Harcourt, presumably triggered in some colonists' minds the violent potential of armed African police within the colony.

\section{Violence, Police, and the African}

As has already been shown, violence and crime were key features of the colony of Natal during its formative period. Violence within the urban centres, particularly Pietermaritzburg, was a constant concern for both European and African police. Particular threats rested in the matter of armed Africans in the streets. Though possession of the assegai

\footnotetext{
${ }^{41}$ The thief attempted to hide the horse in a kloof and leave the kraal without the animal in his possession, hence creating an alibi. It is implied that the ruse worked initially on the African constable, the horse thief was captured the next morning with the horse in his possession. "A Kafir Detective", The Natal Witness, February $17,1871$.

${ }^{42}$ Because of the limitations of colonial records in regards to Africans, Budaza is not listed in colonial documents beyond this account, though considering the praise he received from the magistrate and court system, he presumably retained his position for some time.
} 
(an African spear) had been outlawed since the 1860s, there remained multiple avenues for individuals to commit violence against one another. Perhaps the most common tool amongst Africans, and some Europeans, was the knobkerrie, an African walking stick with an enlarged end either of carved wood or some other material. Calling it a walking stick would perhaps be misleading. The item was an efficient club that had been used by the Nguni and specifically Zulu as not only symbols of status, but also as a practical weapon when others were not available. So effective were these "kerries" that they were typically implemented as the primary weapon available to "native police", and were interchangeable with the truncheons of the European constabulary. The possession of such weapons became so pervasive that in 1862, Lieutenant-Governor John Scott issued a proclamation prohibited the possession of these "knob-kerries", or "Amawisa" as they were known in Zulu, in the towns of Natal. ${ }^{43}$ This proclamation was part of grander attempt to force Africans into presenting themselves in a more "civilized manner", including the requirements to wear trousers ("covering at least from the waist to the knee”) while in Pietermaritzburg and Durban. ${ }^{44}$ Africans caught with such weapons would be forced to pay a fine of up to five shillings and their weapons would be confiscated. To ensure these weapons would not be found in the townships, Scott intended to appoint an African or two within each borough "to act as Special Police to enforce obedience to my [Scott's] aforesaid order, and for the further purpose of causing the order requiring all native resorting to, or dwelling in the towns, to wear proper clothing be observed." ${ }^{45}$ Though it remains unclear how independent these "special police" were, it illustrates the growing concern within the colony of not just the appearance or "social morality" of the African population within the colony, but also the means of violence they had at their disposal. Such provisions did not extend beyond the townships, but Scott did recommend that the chiefs of

\footnotetext{
43 "Proclamation By His Excellency John Scott, November 22, 1862," The Natal Government Gazette, December 2, 1862.

44 Ibid.

${ }^{45}$ Ibid.
} 
local kraals, in exercising their own "salutary power", ensure such recommendations were followed. Despite Scott's proclamation, this special police seemed to have little impact on the presence of such weapons in the townships even into the following decade, as the kerrie remained a key weapon in the enforcement of crimes by the African police.

On multiple occasions, Africans and Europeans would implement these weapons with deft precision, sometimes to the detriment of their own success as constables. One such incident, reported by the Natal Witness, occurred in Pietermaritzburg on September of 1873. A European and African constable saw an African man in the streets carrying a strange parcel. On seeing the policemen, the African threw away the parcel he was carrying and ran. Both the constables gave chase and while the white policeman fell into a sloot, or ditch, at some point in the pursuit, the African policeman (who remains unnamed in the report) "courageously followed the runaway, and being fleeter of foot, or in better training, he overtook his man" on a wooden bridge leading out of town. ${ }^{46}$ The African turned to the policeman and stabbed at him with an assegai, which the policeman was able to wrench out of his grasp. As the African policeman recovered from the struggle, the assailant ran away, and neither policeman was able to find him along the riverbanks. According to the report in the Natal Witness, the case was brought before Mr. Bird, the resident magistrate, and the African constable reported he could have captured the assailant, but "in consequence of one of his brother policeman having lately been sent three months to prison for using his knobkerrie, he was afraid to strike with his." ${ }^{47}$

The editor of the Witness immediately called into question such limitations, claiming they impeded the fulfilment of the constabularies' duties. The question rested on how to teach the police when to use their deadly knobkerrie: "If the native policemen continued long

\footnotetext{
${ }^{46}$ The Natal Witness, September 26, 1873.

47 Ibid.
} 
enough in the service they would soon learn their duty, but they will not remain at work more than a few months as we all know to our cost." ${ }^{48}$ Such incidents and reservations, whether they were felt by only the Africans, or the African and European police, illustrate the great strain that rested on the police forces of Natal. To incentivize the longer service called upon by the Witness, it was encouraged that the colonial government should approve an increase in pay for the police from $£ 7$ to $£ 8$ a month and have an increase in pay for every year a policeman was in service as well as the possibility for pension. Though this would seem extraordinary, the Witness encouraged colonists to "look round at the reckless native population that is being reared amongst us, and ask himself whether a thoroughly efficient police force will not be required, and whether the employment will not be one of great risk" 49 and these extended measures would seem small in comparison.

The brutal use of the knobkerrie was not completely unfounded, at least within Pietermaritzburg. Earlier in 1873, Frederick Heely was charged with disturbing the peace over a quarrel centred on the buying of a horse. Heely claimed to have been abused and beaten by the African police who arrested him with their knobkerries. According to the court report, though Heely's complaints related to police brutality were found to be baseless, the judge of the case suggested that an "inquiry into the conduct of the native police must be made, as he was of opinion that the knobkerries they are armed with were weapons of a nature too formidable for the purpose they were employed for." ${ }^{50}$ Another example of the brutality of these weapons was reported in a letter to the editor of the Witness in which the writer, signing his letter "Viator" described how a group of "native constables" chased after one of his servants, a young African boy. One constable "finding that he was losing ground, threw his knobkerrie with such unerring aim as to shatter one of the boy's ribs", but was still

\footnotetext{
48 Ibid.

${ }^{49}$ The Natal Witness, September 26, 1873.

50 "Borough Police Report," The Natal Witness, February 25, 1873.
} 
unable to prevent the boy's escape, as the boy was able to reach his master's home. ${ }^{51}$ "Viator" also questioned the use of this weapon by the African police, wondering why "such men as these should be allowed to use such deadly instruments upon life and limps of people who are really and truly British subjects?"52

The presence of an armed African with the assegai in the September 1873 incident prompted even greater concern, and the Witness called for the corporation (the government body of the town of Pietermaritzburg) to take steps to "check and suppress the evil". ${ }^{53}$ Though the assegai and other weapons were outlawed in the townships, stories of violent murders caused by the weapons remained in the minds of much of the colonial population. This included a particularly brutal murder of one Zulu by another in Victoria Country in 1872, in which the murderer killed his victim with several strikes from an assegai during a hunting trip, leaving the body to be found only a short distance away. ${ }^{54}$ Such instances of brutality led some in the press to claim that unless more improvements were made "every man will soon have to carry his revolver, and vigilance committees will have to be formed to administer justice." 55 Even as late as the dawn of the Anglo-Zulu War, the mayor of Pietermaritzburg complained to the colonial government about the undesirable nature of Africans passing through the streets in violation of city bye laws with "any interference with them by our Police Force would doubtless have resulted in a breach of the peace." ${ }^{\circ 6}$ Of course, no major funding increases would take place in the colony, and the only real concerns for violence within the African population were easily summarized in the report by one

\footnotetext{
51 “The Native Policeman Again”, The Natal Witness, September 4, 1879.

52 Ibid.

${ }^{53}$ Natal Witness, September 26, 1873.

54 "Sworn Deposition of Umhlutywa before the Resident Magistrate, Country of Victoria, Tugela Division", AGO I/8/14, 502A/1872.

${ }^{55}$ Natal Witness, September 26, 1873.

56 "The Mayor of P.M.Burg: Complains of the noise made by Armed Kafirs passing the Main Street of the city." CSO 673, No. 4868, 1878.
} 
resident magistrate: "As far as the Native population is concerned an increase of Crime is the natural effect of continued contact with civilization." 57

Another episode illustrating the effective use of the "kerrie" occurred in June 1878. An African named Salawani was "wanted" by Durban police for cattle-stealing from Mr. Field of Pinetown. Near Pietermaritzburg, a group of African police came across him, and Salawani bolted. Quick to respond, one constable, "in order to stop him, threw his Kerrie, which, taking him at the back of the neck, knocked him senseless." ${ }^{58}$ Though distance is not revealed, the effectiveness of the African constable use of his primary weapon is on full display in this account. The damage appeared great, since the constables took Salawani to the hospital, fearing he was dying. Ironically, Salawani escaped again, but was later captured. No warrant, however, was officially authorised for his arrest, prompting future inquiry on whether such violent police action was truly necessary within the colony.

Incidents of "police brutality" would remain a contentious point within the colony for much of the formative period. In April 1863, a letter to the editor of the Witness from Mr. Baxter of Pietermaritzburg focused on an incident involving the murder of a neighbour's cow. Initial suspicion fell on an African servant of Mr. Baxter. Ultimately, an application for arrest was drawn up by the borough inspector, resulting in a white constable with a number of "native police" taking the suspected African into custody. It was eventually revealed that the neighbour was the one responsible for the death of the cow and charges were dropped, but it was the capture of the accused servant that was most telling of police treatment of prisoners. The servant was mobbed by a host of African police officers on Baxter's property, his clothes torn, and, according to Baxter, without his intervention the servant "might have been

\footnotetext{
57 "Report of the Attorney General for the Year 1875, On Crime", Natal Blue Books, 1875.

58 “Trapped at Last”, The Natal Witness, June 13, 1878.
} 
strangled". ${ }^{59}$ Baxter was particularly shocked at the lack of just cause for such a brutal arrest. The only evidence rested on a leg of beef hanging in a tree near the African servant's home, which was seen as cause enough for his capture (despite later examination revealing that the cow in question still had all of its legs). Again, the unjust treatment of the African servant and the brutality of the police were the initial topic of conversation, but Baxter's complaints moved toward a criticism of the police institutions in general. His greatest concern was not for the safety of his African servants, but instead of the overreach of the law in this particular case: "For, at the will or caprice of any evil-disposed person, your or I might be dragged from our home and family on any alleged crime to be locked up in a prison until innocence in proved. ${ }^{60}$ England, the source of most legal inspiration, was called upon to be an example, were a warrant should be issued for the apprehension of any suspects. This letter is almost an insightful examination of the working of law in the colony, but it quickly becomes a typical angry letter to the editor. The final cause for such an instance was not a nefarious plan or a complete disregard for legal practice. Instead, Baxter claims that all "was done to annoy me." ${ }^{\prime 1}$ Instead of challenging such order with radical change or reform, Baxter's solution was instead to make note of these "annoyances" and create a series of letters to the editor that would continue as long as the paper gave him space in the columns. ${ }^{62}$ Again the "brutality of the police" remained a catalyst for debate and conversation, even if that conversation was only a vent for colonial frustration.

In another incident in December 1875, seven African police were brought before the resident magistrate of Pietermaritzburg charged with ill-treatment of a "native prisoner."63

\footnotetext{
${ }^{59}$ The Natal Witness, August 21, 1863.

60 Ibid.

${ }^{61}$ Ibid.

${ }^{62}$ There is little evidence that Baxter became a regular contributor, and there appear to be no other letters in his series of complaints to the Witness.

63 "Brutality of the Native Police", The Natal Witness, December 10, 1875.
} 
Four witnesses, at least two Europeans, reported seeing an African running across the field during a horse race followed by several Africans of the borough police. After stumbling into a ditch, the police caught up to him and beat him with their clubs "instead of lifting him up." 64 Four of the African police were reported to have struck the suspect repeatedly upon the head with their sticks. According to the report, there was no evidence that the man deserved arrest, only that he ran away when the police attempted to take him. The magistrate gave the police credit for continuing to perform a difficult duty, but stated that in cases such as this, "it was obviously unnecessary for seven of them to take into custody one defenceless man and to ill treat him when they had him in their charge. ${ }^{\circ 5}$ The magistrate fined four constables, who were perceived to be the principal offenders, 15 shillings each, half of the fines to go to the ill-treated African. As such an incident would give fuel to critics of African police brutality, it is telling that the report was countered by the Times the following week, reporting that the assault was actually three on three and not seven on one and that the fault fell not with the police but the magistrate, as he had not fully investigated the incident, or allowed for the African police to properly state their case but instead rely on the European witnesses. ${ }^{66}$

It remains telling that the perception of police violence could also be a continuation of racial views of the African population. In May 1875, a writer to the Mercury, identifying himself as "A Victorian", took exception to an expressed opinion in the Witness lauding the peaceable demeanour of the African population. "A Victorian" reported that on a mission to place a beacon near a native location, he and the African constable who accompanied him were both threatened by Africans "armed with sticks and assegais" warning the two not to return to that location again. ${ }^{67}$ Again, our only source for such an incident is an unnamed

\footnotetext{
64 Ibid.

${ }^{65}$ Ibid.

${ }^{66}$ The Times of Natal, December 14, 1875.

${ }^{67}$ The Natal Witness, May 25, 1875.
} 
European, whose view of the actions could be called into question. The presence of the

African constable could have either exacerbated the situation, or acted as a deterrent from

further violent action. It was even possible that "A Victorian" could have simply

misinterpreted the armed Africans' actions.

Though these incidents and figures are only small samples of the police incidents that took place during this period, they illustrate the complexities and problems faced by the constabulary organizations of the colony of Natal. In no way were such instances distinctly the work of Africans. In 1854, a woman named Jane Meek Thompson, described as a “dissolute character", was brutally murdered in Pietermaritzburg. Though her body was mutilated by some type of blade, the cause of death was a heavy stick, similar to the knobkerrie in the possession of one of the suspects. Though the weapon was claimed to be used to help defend against dog attacks, its viability as a murder weapon was confirmed by the court medical expert. ${ }^{68}$

Though no conviction was made in the case, there was no suspected involvement of an African, yet the kerrie was the likely tool for murder. When attempting to limit the use of these weapons, the threat of violence is seen to come largely from the African population. Even when police brutality is chastised, it was the African, and not the European officer who received the most criticisms. Nevertheless, when called upon to prevent such violence, it was

68 "District Court-Criminal Sessions", The Natal Witness, February 24, 1854. The murder of Jane Meek Thompson on December 15, 1853 is a fascinating case study that illustrates the violence of the knobkerrie, but also the procedure of evidence collection of the police. Alexander Anderson, the accused and "roommate" of Ms. Thompson, and Richard Corish, a soldier whose room Thompson's body was found in, are two very interesting characters in Natal's early history. The two seemed to create a story that was in conjunctions with one another, but cast enough doubt to reveal some nefarious purpose; especially in the timing of the discovery of the body as Corish was drinking at Harwick's, another resident of the town. The Witness provided its own commentary, stating that the only supposition to Corish's story is whether or not it was true, or if he in fact returned to the room while fetching peg-wood for Harwicks, killed the woman, and mutilated the body with some kind of blade, and returning to Harwick's very quickly (though there is nearly a three quarters of an hour that passed between the time be left the deceased at the house and returned). Other supposition included a conspiracy between Corish and Anderson. Not surprisingly, the jury found a verdict of wilful murder, but found no proof that Anderson was the murderer, leading to Anderson's acquittal. Such a case needs further study, and could provide a fantastic foundation to a deeper analysis of colonial law in early Natal. 
the African constable who was the first line of defence in the townships. Violence was a consistent theme in the lives of the police, from the weaponry to the means of paying for the constables on the street. There remained, however, a level of uncertainty and apprehension within the colonial population over the role of the African constabulary in the peace and safety of the colony. Though some constables knew something about murder, it was the general violence they faced, and sometimes propagated, in the rural and urban centres of the colony that truly defined their place in the development of Natal as a colonial state in the British Empire during the nineteenth century.

\section{Firearms, Regulation, and Weaponry}

Armed violence, as has been illustrated, was not a constant feature of Natal during its formative period, but remained an important component in the gradual evolution of the colonial state. Despite the increase in armed white European organizations, such as the volunteer and rifle associations previously discussed, the concept of an armed Africa was both concerning and dangerous in the eyes of the European population. Refugees, and more importantly the weapons they brought with them, had been a general concern for the colonies since the 1850s. In 1857 one of the first large groups of refugees from the Zululand were permitted to retain possession of their short spears, or assegais. This decision caused considerable concert over an armed section of the African population present within the colony, if not within the established locations. These concerns were heightened when reports soon began to circulate that some of the Africans working for Europeans were fashioning new weapons in the "kitchens of their employers or the huts where they sleep, at times when they believe themselves unobserved." ${ }^{99}$ Though such actions were apparently linked to concern over an unfounded invasion of Mpande, these accounts led to the even larger questions of why the Africans would need to construct such items and what other Africans in

69 “The Refugees and Government," The Natal Mercury, February 4, 1857. 
the locations were doing outside of the constant observation of the Europeans. Even by the conclusion of the $1850 \mathrm{~s}$, this trend toward a greater availability of weaponry was part of a shift in the economic development of Natal and South Africa as a whole. While items like the assegai were presumably already in African possession, this economic development of Natal as a whole allowed for greater access to weaponry on a much larger scale. It was no surprise then that the most important debates by the 1850 s and 1860 s regarding security and the African centred on ownership and control of firearms and the African polices role in enforcing law associated with said firearms. ${ }^{70}$

Firearms remained an important component of the African's perceived used of force within the colony, and endured as a central point of debate for the majority of the colony's formative period..$^{71}$ Though the limitations to such firearms were not uncommon to all members of Natal's community, including the white population, particular care was made to avoid the mass arming of the African population. Though the "gunpowder bill" of 1857 made no specific mention of the African population, except in the case of those taking part in the illegal sale not sanctioned by the government, this omission was quickly rectified. ${ }^{72}$ By November 1858 , a bill was put forward by the legislative council that would formally prevent the possession or sale of firearms to the African population of the colony. In essence, it was completely unlawful for an African to own or possess any guns, pistols, or gunpowder in the colony without the written permission of the lieutenant-governor. ${ }^{73}$ Anyone granted

\footnotetext{
${ }^{70}$ For the shift that took place in the Southern African economy during the mid-nineteenth century and its contribution to the proliferation of firearms, knows as the "breechloader revolution", See William Kelleher Storey, Guns, Race, and Power in Colonial South Africa (Cambridge; New York: Cambridge University Press, 2012), 118.

${ }^{71}$ It would also act as the catalyst for further, larger conflicts, such as the Langalibalele Rebellion of 1873. See Chapter Three: Volunteers and Chapter Six: African Military Units.

${ }^{72}$ Farmers are the most commonly cited group in the individual possession of gunpowder, which was becoming greatly regulated during this period. See "Bill: For Regulating the Dealing in Gunpowder, May 11, 1857", The Natal Government Gazette (Extraordinary), May 13, 1857.

73 "Bill: For preventing the Sale of Gunpowder and Firearms to, and prohibiting the possession of the same by, Natives, November 24, 1858," The Natal Government Gazette, November 30, 1858.
} 
permission would have their firearms marked and registered by the resident magistrate, and a record of all firearms in the colony would effectively provide the information necessary to keep track of said firearms in Natal. Even if an Africa was found in possession of a registered marked gun, if they themselves were not granted permission by the colonial government, the firearms would be seized and they would be forced to pay a fine for possession which would not exceed $£ 50$. A similar fine would be imposed to anyone caught selling firearms or gunpowder either within Natal or to individuals of the colony in adjacent countries. In both cases, such unlawful property would be seized and become the property of the government of Natal.

By June 1859, the bill was signed into law by Lieutenant-Governor Scott, with one minor alteration. To insure the clarity and legal basis for the law, the individuals who would be primarily responsible for such seizures were outlined. Any member of the magistracy, or policeman, could "stop any person of the native tribes of this colony, or any native of the tribes residing in the countries adjacent thereto, who may have in his possession... any gun, or pistol, or gunpowder, and seize the same, and forthwith carry the offender before the resident magistrate, or Justice of the Peace, of the county."74 This change to the bill was illustrative of the major limitations to such legislation. Without a viable police force that could interact with the Africans, it would be nearly impossible to successfully implement such laws. Constable Budaza would have been incapable of easily discovering the firearms confiscated in his case if he was not able to freely move amongst the African population. With this is mind, firearms were only one aspect of the complicated nature of the African's relationship with the law.

Though firearms and gunpowder laws addressed the transport and sale of such items to the colony as the whole, only the African population was specifically cited as a source of

74 "Law No. 5, 1859: For preventing the Sale of Gunpowder and Fire-arms to, and prohibiting the possession of the same by, Natives, June 25, 1859," The Natal Government Gazette, January 1, 1861. 
greater and greater concern. The proliferation of firearms, in what has been called the "breechloader revolution", made the ownership of guns far more dangerous, with the shift in British racial ideology and the mineral revolution all causing a greater call for gun control in the 1870 s. ${ }^{75}$ In this context, guns became a conduit for imperial control, but also showed the more dramatic shift to a racialized view of the African from within Natal, and more importantly, the Empire as a whole.

\section{Race and Police Work}

This fear of the "other" from the colonists was counterbalanced by concern for the safety and stability of the indigenous population of Natal, all fuelled by the growing size of the African population during this formative period. Many Europeans believed in the necessity for changes within the colony for not only economic prosperity, but its overall safety as well. In many ways, the inability to "keep an eye on" the African population in the locations directly resulted in greater apprehension and an overlaying fear. Not surprisingly, those threats of violence, or the overlaying of black authority over white, became an issue with the increased interaction between African police and the European populace. Consequently, tension over what Africans might do with this newfound authority and the threats to white rule were a constant theme in the racial interactions within Natal during its formative period. The power of the African police, as highlighted by Budaza, was evolving quicker than most in the colonial government were willing to allow.

Such concerns persisted from the establishment of the first African police forces in 1848, yet there remained a continuing concern that African police would simply be insufficient compared to their white counterparts. Even some members of the legislative council as early as 1858 made attempts to limit the number of Africans in the constabulary

\footnotetext{
${ }^{75}$ See Storey, Guns, Race, and Power in Colonial South Africa, 144.
} 
and replace them with Europeans, startlingly at the cost of losing a number of resident magistrates within the colony. One member of the legislative council even contended that the money "might be laid out to more advantage... and if $£ 800$ were expended in payment of a few white police men, the colony would thereby derive much more benefit from that arrangement than they now did through the magistracy". ${ }^{76}$

The member's major qualm with the current system, however, did not rest in the lack of success from the magistracy, but instead on his personal concerns over the use of African police. He argued that "no white man could see, without pain, a man of his own color dragged off by native policemen", leading to an even greater need for more white officers. ${ }^{77}$ The council member was not alone in his objections. The Colonial Secretary of Natal, David Erskine, while correcting the council member on his figures ( $£ 800$ was $£ 700$ short of a proper estimate), agreed that it was inconceivable for an African to be responsible for the apprehension and arrest of any white colonists. According to Erskine: "white men were averse to being given in charge of native policemen" and "white people should not deserve to fall into such hands". ${ }^{78}$ The colonial secretary also expressed his disapproval of the principle of employing Africans as policemen, but could not deny that the employment of Africans to the police force was an overall benefit to the economy of the colony.

Such debates did not end quickly. The following year, the question of African police was once again on the agenda, though only on the periphery of a debate regarding extra pay for the magistracy of Durban, the clerk of the peace, and the constabulary of the colony as a whole. Again, the economy of cost remained the surface issue underpinned by the racial apprehension which existed within the legislative council. The members of the council,

\footnotetext{
76 “Legislative Council Report", The Natal Witness, May7, 1858.

77 Ibid.

${ }^{78}$ The Natal Witness, May 7, 1858.
} 
including Theophilus Shepstone, praised the magistrate of Durban for his hard work, alluding that his salary should be doubled. This originated from the revelation that the "gentleman actually kept up a valuable corps of native police at his own private expense and had hitherto only received pay for a clerk." 79 Whereas Shepstone claimed the magistracy of Durban "expended five times more than he received from government" it such cases, there appeared to be a discrepancy in these numbers. ${ }^{80}$

Outside of the county of Pietermaritzburg, the county of Durban received more funding for police than any other in the colony. Not only did the county have a chief constable as well as six European constables, but it also included eight "native constables", three for the borough and five for the district, at a total cost of $£ 502 .{ }^{81}$ No doubt an "efficient officer" as described by Shepstone, it is unclear if these additional African police, alluded to be at the personal expense of the magistrate, were simply included in the colonial figures, or if, like Shepstone's own Mtintandaba, were an additional force at the disposal of the colonial government not listed on the expenses. ${ }^{82}$ Whatever the source of these expenses, as the African police were praised by Shepstone, they were once again made a point of disdain from other members of the council.

In the same council meeting, the constable at Weenen was also appointed. Such action was praised as a "most judicious appointment" by the council representative of Weenen and Speaker for the Legislative Council, Walter Macfarlane. ${ }^{83}$ Macfarlane also used the opportunity to express his strong opposition to the employment of Africans exclusively in constabulary offices, repeating the sentiment of the previous year that there was considerable

\footnotetext{
79 “Legislative Council”, The Natal Witness, May 13, 1859.

80 Ibid.

81 "Civil Establishments", Natal Blue Books, 1859.

${ }^{82}$ For more on the Mtintandaba, see Chapter Six: African Units.

${ }^{83}$ The Natal Witness, May 13, 1859.
} 
apprehension within the council and the colony as a whole over the "deplorable consequences which would inevitably ensue through the continuance of the practice of permitting apprehension of Europeans offenders by Kafirs." 84 The source of this apprehension, though masked in concerns for proper security, had obvious racial connotations. As representatives of the people, the opinions of the legislative council are telling to the sentiments of the colonists as a whole. Though acknowledging their importance and cost saving measures for the colony, there was an undertone of disdain and complete lack of respect for the African police. Such enmity was clearly evident in several interacts between the African police and the white population of the colony during the formative period.

In 1876, Mr. James Manning, a farmer of Berea was fined two shillings and six pence by the resident magistrate for "interfering with the native police in the execution of their duty." ${ }^{85}$ The incident involved one of Mr. Manning's African workers, a boy, and an African constable, who claimed the boy was "insufficiently clad" in conjunction with the town ordinances of 1862. As soon as the boy saw the constable, he ran away toward his master's house, with the constable giving chase. Outside Mr. Manning's house, the constable overtook the boy, but was preventing from taking him into custody when Manning pushed the constable to one side, allowing the boy to get on his master's private grounds, where jurisdictional rules prevented the constable from pursuing the boy further. Manning, in his defence, denied striking the policeman until he came upon Manning's private property. Despite the fine, the blatant disregard for the African police authority in this matter, while not completely unique to the police during the period, does illustrate the strikingly racial divide which permeated the police work during this period. Such attacks were not limited to the urban areas as well. In August the same year, Edward Brewer and his brother Henry were

\footnotetext{
${ }^{84}$ Ibid.

85 "Interfering with the Native Police", The Natal Witness, February 25, 1876.
} 
charged with assaulting one of the African police of the Umgeni Division. Again, evidence was given for the assault and Edward Brewer was fined five shillings. ${ }^{86}$ These incidents were not isolated, but did occurred when the African constable was alone and without the support of his European counterpart. Yet, even when accompanied by European constables, the African police did not receive universal respect in the colony.

In Durban during March 1876, an African constable attempted to stop a wagon on the open space at Gardniner Street, as a local ordinance had been passed which forbid such wagon trains moving through the street. Mr. Benningfield, the head of the convoy, "got on to the wagon and called out to the constable to 'suka' [likely sukkel, or Afrikaans for "plod along”], saying it was no business of his." ${ }^{87} \mathrm{He}$ was then informed by Mr. Forester, a European constable, that it was against the bylaws to have wagons cross the grounds. Benningfield responded that he saw no notice and immediately ordered his wagons to turn around, dismissing the constables. Forester took the driver, a boy, into custody as a witness and reported the event to his Sergeant. Only when the Sergeant arrived did Benningfield respond "Mr. Sergeant, what is it I can do for you? What is your business?"88 After speaking to the Sergeant for a half hour, he eventually came to the police station. Though the resident magistrate did not approve of the method of his arrest, he did fine Benningfield two shillings six pence for offending against the law. While Benningfield, possible a Afrikaner, was presumably more dismissive than others of any colonial authority, much less African authority, the fact that he did not consider stopping his wagons until a European constable took away his driver and eventually brought in his sergeant is indicative of the manner in which some colonists dismissed African authority.

\footnotetext{
${ }^{86}$ The Natal Witness, August 11, 1876.

87 “The Arrest of Mr. Benningfield”, The Natal Witness, March 24, 1876.

88 Ibid.
} 
Whatever the personal opinions of Benningfield, there was a clear concession amongst many colonists that the African police, while a necessary component to some degree of colonial security, were not completely necessary for the proliferation of law and order amongst the white population of the colony. Nonetheless, the racial component of these opinions cannot be ignored. The need for effective police was called upon almost universally, but the use of African police against the white population was perceived as a slippery slope to utter anarchy. Similar concerns would present themselves in the use of Africans within the military organization of the colony as well. When concerning the use of Africans against other Africans, however, there was no more viable candidate than the African policeman for the duty of law and order during the formative period of Natal. This became even more viable as the colony continued to wrestle with the concerns over law, order, and labour.

\section{"Natal Policemen would be very vigilant...": Labour, Change, and Reform}

Before the Langalibalele Incident of 1873 , the primary concern of the colonial population was not necessary an African revolt, but instead creating an answer to the influx of African labourers in 1872. The usual European reaction to the growing number of "refugees" for much of Natal's history was to transform the newly arrived African population into a labour force. Though new regulations in the late 1850s allowed for the limited use of refugee labour, but Shepstone's policy was still seen by some as frustrating a "golden opportunity." ${ }^{\prime 99}$ These refugees from the Zululand were perceived to be escaping certain slaughter in their original homeland, and under the parameters set by the charter of Natal, would be placed under the authority of the supreme chief, or lieutenant-governor.

Disapproval of the handling of the labour issue resulted in scathing criticism in the press, particularly the loss of a key opportunity to incorporate the Africans into apprenticeships. Under the refugee system still in place in 1872, any labourers who did seek employment after

89 “Refugee Labour,” The Natal Mercury, January 15, 1857. 
the one month grace period were not tied exclusively to their employers. Even with the creation of a service period of three years amongst these refugees, there were limited regulations to keep Africans within their employment. Employers complained of African labourers leaving or even "running away" from their place of work, leading to the classic impression of the lazy African worker, fleeing to his kraal without any "gratitude" for the opportunities provided by their European employers..$^{90}$ Ostensibly, this criticism focused on the locations system for their improper regulation and incapability of limiting the travels of Africans within the colony. ${ }^{91}$

The debate over this issue of refugee labour also clearly illustrates some of the differences between the major newspapers of Natal, specifically the Natal Witness and the Natal Mercury. The editors of the Natal Witness called such practices of three year apprenticeship labour contracts by the European population "slavery", while the editors of the Mercury declared this simply a product of ignorance..$^{92}$ Even within the European population, the proper implementation of indigenous labour was widely debated in the public sphere. Clear evidence of this exists in the letters to the editor of both the Natal Mercury and the Natal Witness. Both editors, however, seemed largely concerned with the issue of safety and security within the colony, which the refugee problem continued to exacerbate.

Ironically, while such debates on labour were a regular refrain for much of the formative period of Natal, it was the African police who provided a key platform in this debate. Many in the colony were particularly critical of the African population's lack of

\footnotetext{
90 “The Refugees and the Government," The Natal Mercury, February 4, 1857.

${ }^{91}$ Such "running away" could also be seen as a form of resistance against colonial rule. It remains unclear the motivations of these Africans who left their employment.

92 “The Refugees," The Natal Mercury, January 22, 1857. David Dale Buchanan, the editor of the Natal Witness, was presumably influenced by his own family's evangelical background in his disdain for the apprenticeship practices. Buchanan was part of Cape Town's humanitarian circles in the 1830s, and his brother, Ebenezer, was a former missionary in Samoa until his arrival in Natal in 1850. See Hattersley, The British Settlement of Natal, 91; Guy, Theophilus Shepstone and the Forging of Natal, 72.
} 
enthusiasm for work, whether in the farms or urban centres of the colony. Others, like the editors of the Witness, disputed such claims as late as 1868 . In a response to a letter to the editor from "Ethiop" claiming that African labourers cannot be relied on, the editor argued that this was only true in a limited sense. The only limiting factor for African labour was not the abilities of such workers, but their availability within the colony, harkening back to the debates over labour in the previous decade. The editor instead argued that the African was the most reliable and obedient group of men: "Whoever hears of a strike among them, or of a complaint from their overseers?"93 So great was the African reliability in Natal that the editor made direct reference to their role in the colony's police establishments:

Upon whom, except in the towns, do the magistrates rely for the prompt enforcement of their orders, and the punctual conveyance of their messages to the uttermost ends of their jurisdiction? Upon whom could they rely more implicitly, or more safety, than on their natives? Whoever hears of a breach of trust, or want of fidelity, or want of attention, or miscarriage of any matter entrusted to a native constable or messenger? ${ }^{94}$

The editors even went as far as to question whether any such complaints had been found in print or amongst the colonists for the past two decades. Though the use of labour could be called into question, it was the African police's role in the preservation of the state that allowed for the African to exhibit his capacity "to be thoroughly reliable." 95 Though thoroughly exaggerated and forgetful of many of the incidents reported in their own paper about "police brutality" in the previous decades, the editors of the Witness's praise of the African police force is telling. It illustrates the police's role as a compliment to the key components of labour within the colony and provides evidence of the perceptions of the

\footnotetext{
${ }^{93}$ The Natal Witness, November 6, 1868.

${ }^{94}$ Ibid.

${ }^{95}$ Ibid.
} 
African police within Natal's European community. Such perceived good will was not universal, or enduring, and would still lead to increased reform as the 1870 s approached.

By 1872 , concerns over the issue of labour were addressed indirectly by the colonial government in proposed reform within the police institutions of the colony, particularly the African police. Such reform came with the passage of Law No.4, "To establish and organized Police Force" in 1874, but preliminary discussions over these reforms were in a direct attempt to address this same issue of African labour. ${ }^{96}$ The influx of new labour within the colony, largely fuelled by railway and road building projects, led the legislative council to once again attempt a greater reorganization of the forces of law and order. Because these projects would result in greater interaction between the whites and blacks of the colony, the council recommended that certain precautions be made to address "the untrustworthy conditions the natives of Natal have already reached." 97

These "untrustworthy conditions" could only be rectified by an increase in the police force within the colony. Because the cost of such a force would only exacerbate the colonial budget, it was instead advised for a gradual increase in the African police force of the colony as required. Though not addressing the distrust felt toward the African population, it could alleviate some concerns for security. The anxiety caused, however, by the African police institutions had not been alleviated since the late 1850s. The council believed that the colonial population, particularly the European colonists, had "almost entirely lost their confidence in the integrity of the Native Policemen, in cases involving danger to any members of their own tribe, or of any other tribe with which they may have friendly

\footnotetext{
${ }^{96}$ For more on Police Law, see Chapter Four: European Police.

97 "Report of Select Committee of the Legislative Council Upon the Introduction of Native Labourers," The Natal Witness, Extraordinary, November 19, 1872.
} 
relations. $" 98$ The praise from the Witness five years before was gone. It its place was the worry that African police, when dealt with other Africans, would provide preferential treatment. Such treatment could conceivably overwhelm the police's responsibility to fulfil their duty.

Though some evident of these practices did exist, the council's alternative was even more illuminating. The council suggested that when "adding to the number of the Native Police, it would therefore be well to incorporate a considerable number of men from tribes beyond the frontier, who have not tribal or sympathies with the natives within the Colony." 99 According to the council's logic, African policemen from beyond Natal's borders would be more vigilant of "foreign" Africans, or at least ones that were not directly know to them. To make the system more effective, the justice of the peace should be conferred limited magisterial functions and the "Police should be instructed to obey the orders of these gentlemen, and to apply to them for advice and assistance." ${ }^{100}$ A general increase in the number of police would be enacted, as "two or three policemen might be permanently stationed at each residence of each of these gentlemen, and have defined districts over which their supervisor might extend."101 By December, there was tentative approval from the colonial secretary for the increase in funds, beginning with a half-dozen police in Pietermaritzburg alone. A larger increase, however, would not take place until after the passage of the Police Law in $1874 .{ }^{102}$

The legislative council was not the only colonial institution that was making recommendations for the Native Police Force during November 1872. The Times was also

\footnotetext{
${ }^{98}$ Ibid.

${ }^{99}$ Ibid.

${ }^{100}$ Ibid.

${ }^{101}$ Ibid.

102 “Legislative council reporting," The Natal Witness, December 6, 1872.
} 
promoting reform, but instead of within the current system, the editors advocated the establishment of a separate Native Police Force with its superintendent and subordinate officers, costing "thousands a-year". ${ }^{103}$ The system appeared to rest on bringing Africans from the north down to near the coastal area to act as this new police force under the direct supervision Shepstone, similar to the police force first established in the colony in 1848 . The editors of the Witness, however, attacked such a scheme as "costly and dangerous" for the colony. ${ }^{104}$ Instead, the editors of the Witness contended that the system imposed by Shepstone in the early years of the colony was no longer practical to the changing landscape of Natal, stating:

Mr. Shepstone believes in his Kafir policemen, and we are not surprised at it. They in former years, before they had been corrupted with the knowledge how easy and safe it is to deceive the magistrate and rob the white men, were faithful servants, and obeyed implicitly whatever instruction they received, and Mr. Shepstone is unwilling to believe they have changed. That day of Kafir honesty is past. ${ }^{105}$

The editors suggested a plan similar to that proposed by the legislative council, in which foreign Africans would be selected as policemen and most effectively stop the "depredation of Natal's" Africans and "disclose and combination of plots which may be formed" by the indigenous population of the colony. ${ }^{106}$ In essence, they believed foreign Africans would act as better policemen. In light of this, the editors argued that to discharge one-half of the African policemen and replacing them with Africans from the north would be all that should be needed to avoid incurring additional expense of establishing an independent force. Even such a measure was seen as a stopgap, as it was argued that eventually the foreign Africans would learn the lessons of Natal's African population, resulting in another larger police force

${ }^{103}$ The Times of Natal (Pietermaritzburg), November 20, 1872.

${ }^{104}$ The Natal Witness, November 26, 1872.

${ }^{105}$ Ibid.

${ }^{106}$ Ibid. 
yet again, but such need was presented as many years off. Again, the major criticism of such a venture involves the overall cost of " $£ 3,500$ for a force which would be more expensive, and quite as unnecessary as were the mounted police."107 The real threat, as was the case with the African police of the 1840 s, seemed to lie in giving Shepstone too much power within the colony, implicating that Shepstone would hold "our prosperity in the hollow of his hand, and can ruin us if he likes" if such a system was implement. ${ }^{108}$

Ironically, Shepstone had little involvement with such a plan proposed by The Times, especially when he had his own solutions to the problems with day labourers in Pietermaritzburg in the summer of 1873. Shepstone's solutions rested on the greater organization of labour, including specific job allocation, license fees, and the use of badges. To aid in enforcing these rules and to insure order in the towns, more funds should be allocated to the police, with Shepstone recommending as a start that "in each borough there should be at least ten additional police and an intelligent white constable in special charge of their particular department, who should, if possible, speak the language." ${ }^{109}$ No major shifts in the location or placement of Africans was suggested, or even the greater consolidation of power. It is, however, possible that this debate between the Times of Natal and the Witness stemmed from personal conflict between the papers and not simply an attack on Shepstone. ${ }^{110}$

Much like the topic of labour, property also continued to influence the debate over police reform. Even the editors of the Witness were asking in April 1873 "Have we, or have we not, security for life and property in Natal?" The account of an African attacking a white

\footnotetext{
${ }^{107}$ Ibid. This is a reference to the "unnecessary" mounted police forces established in the 1860 s, which were wrought by scandal, corruption, and ineffectiveness. See Chapter Four: European Police.

108 Ibid.

109 “Mr. T. Shepstone's Memorandum on Kafir Day-Labourers”, The Natal Witness, June 20, 1873.

${ }^{110}$ It is particularly difficult to detect any political agenda or dispute that comes from these papers, largely due to simple limitations of access. As Guy suggests, further work is necessary on understanding the "immediate political role of newspapers" instead using them as simple a source of information. See Guy, Theophilus Shepstone and the Forging of Natal, 540.
} 
constable appeared to be catalyst for a call for change. The fact that the African was acquitted for such actions raising the simple question: "How can we expect to get men to serve in a police force - an office necessary from its very nature attended with more or less of dangerif the Law, or the administrators of it, refuse to protect them?"111 Multiple instances of such assault were outlined, including one by an African attacking an "unoffending" soldier of the $75^{\text {th }}$ Regiment and another involved and African being found in the streets at 11:30pm, and when challenged by the police, "struck the policeman with a violent blow, and ran away...The police followed him into his master's kitchen, and there arrested him after a desperate resistance." 112 Perhaps the most egregious component of this latter case, according to the editor, is that when brought before the magistrate, the offender was only charged five shillings for vagrancy. Though the charges were balked at, the source of such a minor charge was the lack of strong evidence or proper charges against the suspect, combined with a police force who "found it necessary in self-defence to use freely, in all cases, their truncheons, since the Law failed to protect them in the discharge of their duty."113

Interestingly, the editorial moved beyond the simple question of protection of life and property and more to an overall criticism of the police institutions of the colony as a whole. Shifting to the county, similar questions were asked by the editor, including why it was the norm to have around half a dozen African constables per district with "perhaps" a white constable at their head. With so few men covering such a large territory "teeming with a savage population, which is daily learning the vices though not virtues of the European", the situation of the police force was a recipe for inevitable disaster. ${ }^{114} \mathrm{~A}$ main problem rests in the issue of jurisdiction, in which the police outside the borough cannot compare to those

\footnotetext{
111 "Have we, or have we not, security for life and property in Natal?", The Natal Witness, April 22, 1873.

112 Ibid.

${ }^{113}$ Ibid.

${ }^{114}$ Ibid.
} 
within. This reveals one of the major discrepancies that existed within the colony during this formative period. There remained little communication or collaboration between the urban and rural members of the police force, as if they were divided by "the invisible boundaries of the town lands." 115 The editors of the Witness, however, were not content with this divide between the urban and rural, despite precedence within the rest of the Empire. This continued the paradox of rural policing within the British Empire for much of the colonial period, in which the primary area of police responsibility was characterised by a weak police presence. ${ }^{116}$

The suggested remedy for these problems for the editors was the creation of a "detective police" force, not of a military character. This force with a speedy and secret method of detection could more easily apprehend offenders in a country "not bounded on all sides by the sea". ${ }^{117}$ A quasi-military force like the Irish constabulary would be useless, since such a system was "very useful in a country where petty thefts are almost unknown while agrarian outrages are frequent". ${ }^{118}$ This regularly-established detective police should compose of at least 100 men, half black and half white. The lead officer of this force should report to only the lieutenant-governor, for speed of communication and rapid response, and be selected for merit and capacity. For this same convenience of communication and to better consolidate the police force in the colony as a whole, the editors also outlined that the borough police would also be under this main officer's management, "which means much expense would be saved to the Corporation, and we venture to think, adequate protection

\footnotetext{
115 Ibid.

116 This was particularly the case in India, as Arnold outlined in his account of the Madras Police. Arnold argues that there were three reasons why the police did not extend to the villages of rural Madras, including the British not wanting to commit more resources to rural policing, the additional financial restrain to state revenues, and "the enduring belief in the utility and validity of a village police system independent of colonial police." This is linked more directly to the belief in self-rule in at least some levels of Indian society. Arnold, Police Power and Colonial Rule: Madras 1859-1947, 99-102.

117 The Natal Witness, April 22, 1873.

118 Ibid.
} 
afforded to the inhabitants of the city and the colony generally." 119 The venture would also, surprisingly, be a cost saving venture for the colony as a whole, as the editors suggested that the $£ 7,000$ annually paid to the volunteers would be used for this new detective force, doing "more for the country than any military body ever could". ${ }^{120}$ The logic was that if such a detective force existed in the colony, the volunteers would be an unnecessary component to colonial defence. Since such a plan would be considerably unpopular to the volunteers, the editors comments on this topic is most revealing to the perceived role of the volunteers versus police in the colony: "We fear those who have recently purchased their new [Volunteer] uniforms will find some fault with these remarks, but it is the duty of a journalist to be guided by the dictates of conscience, and to speak 'without fear, favour, or prejudice' when he considers to be for the good of the country."121

Though such a plan had no support from the colonial government and was never pushed beyond the pages of the Witness, the editorial does present a revealing attitude toward the use of Africans in Natal's police force. Again, the people of Natal called for hybrid system in the establishment of defensive institutions within the emerging colonial state. Not only were Africans encouraged or even assumed to be part of such a dramatically reformed force, but the fact that they would be included as a "detective force" reveals the perceived potential of Africans within the police force as a whole. The feasibility of the volunteer systems being completely removed was implausible at best, and consolidating the borough police under a single, colony-wide force would be counterintuitive to the greater independence achieved by the corporations in the $1850 \mathrm{~s}$. The scheme, unlike many others within the colony which called for a larger, more militaristic force, called for greater precision and preventative measures for future problems within the colony, instead of a force

${ }^{119}$ Ibid.
${ }^{120}$ Ibid.
${ }^{121}$ Ibid. 
of intimidation to the indigenous population of Natal. Nonetheless, the consolidation of police forces was a growing component of Natal's perceptions of colonial defence and the call for reform would be answered by 1874 .

One final push for reform was made for the African police before the passage of the Police Law in 1874. Though the bill for the establishment of an organized police force was put forward in November 1873, which included provisions related to the African police, other recommendations were put forward in December legislative council meeting. ${ }^{122}$ At the meeting, Charles Barter, council member from Pietermaritzburg, suggested a greater formalization of the role of the African police officers, especially as it pertained to a new "Native Police Force". According Barter, there should be an appointed resident constable over a certain number of kraals, and that "that such officer should wear a badge, and be paid for the duties he performs; that he should be armed with assegais and Kerrie only, and be dressed in a cheap uniform". ${ }^{123}$ Such a constable would be required to report to the nearest police station on every occurrence of local problems, as well as the arrival and departure of any Africans from within his district. This constable would be held responsible for the general order of the kraals within his care, as well as act as the catalyst for the introduction of "Tribal Responsibility". The proposal seems to have general support and it was calculated that " 180 men would be required. The officers appointed would be required to visit the kraals more than once or twice a month so that the requisite inspection could easily be carried out with this number... estimated it would cost about $£ 2,000$ a year." 124

Shepstone was not present at this meeting, and there seems to be some reservations about moving forward without his input. Elements of these proposals, however, were clearly

\footnotetext{
122 "Bill No. 11: To Establish an organized Police Force, 1873", Natal Government Gazette, November 4, 1873. 123 "Extra Legislative Council, Wed. Dec. $3^{\text {rd }}, 3$ PM: 'NATIVE POLICE'," The Natal Witness, December 5, 1873. ${ }^{124}$ Ibid.
} 
seen in the new police law of 1874 . The total number of non-white police ("Natives of Africa or India") would be 150. Under the law, the lieutenant-governor had the authority to "appoint such number of resident detective native constable as he may deem necessary, and may assign to each such stable a certain number of native kraals for supervision." 125 This special constable would also be required to report to not only the nearest police station, but also to the resident magistrate, "all occurrences, as well as all arrival in and departures of Natives from his district" as well as enforce orderly behaviour amongst the Africans under his supervision. ${ }^{126}$ Though not an independent police force, this semiautonomous status was a general boon to the advocates of a more direct hand in the African community and law. The new organization did not fundamentally alter the relationship between Shepstone and his magistrates, as well as the administration of law within the colony, but did lay the groundwork for future changes and codification of African law, culminating in the 1878 Code of Native Law which fundamentally changed the power structure of Natal's legal and political order which had existed for decade before. Again, the African becomes a representative of the shifting political and legal landscape within the colony of Natal, and the police's role in that shift was fundamentally impacted by the Africans who attempted to maintain such changes within Natal's evolving landscape. Consolidation and reform would be the theme for the continuing decades, and in July 1894, the Natal Mounted Police, Native Magisterial Police, Railway and Water Police, European constables, messengers at magistracies, gaolers, warders and convict guards were all amalgamated into one force under the title "Natal Police". Complete consolidation of the police forces, however, would remain

125 “Law No. 4, To Establish an organized Police Force, January 12, 1874," The Natal Government Gazette, January 20, 1874.

${ }^{126}$ Ibid. 
elusive, as Pietermaritzburg, Durban, Newcastle, and Ladysmith retained separate police forces for the remainder of the decade. ${ }^{127}$

\section{Pay, Compensation, and Organization}

Even with the call for reform from many elements of Natal, the African police remained the most viable option for the colonial government. Despite the attempts and criticisms of reform in the urban areas of the colony, the rural segments of the police force, those not under the direct control of Shepstone, were under the prime jurisdiction of the local resident magistrates. ${ }^{128}$ It was their responsibility to insure payment and proper implementation of law and order within their particular districts. However, in further examination of these districts and divisions, there are glaring disparities in the pay, composition, and organization of the African police. Once again, the makeup of the African police illustrated the limitations imposed on the colonial defensive structures.

As has been previous alluded to, in most cases rural districts contained only a handful of constables and were typically almost complete composed of African constables, usually with only one European constable. In the case of the Tugela Division in Victoria County, from the district's creation in 1855 to 1863 , there were only "native constables" responsible for the maintenance of law and order. The number fluctuated from four in 1855 to seven in 1861, until the appointment of one European constable along with eight African constables in 1863. ${ }^{129}$ This is perhaps most shocking, considering the Tugela District's population in 1859 was 14,304 with 354 of that number Europeans. ${ }^{130}$ A ratio of over 2,000 people per constable

\footnotetext{
${ }^{127}$ Colin de B Webb et al., Webb's Guide to the Official Records of the Colony of Natal (Pietermaritzburg: University of Natal, 1984), 172.

${ }^{128}$ As will be discussed in the next chapter, Africans who worked directly under Shepstone are representative of a unique category in Natal's defensive structures.

129 "Civil Establishments: Police and Gaols”, Natal Blue Books, 1855-1863.

130 "Population", Natal Blue Books, 1859.
} 
in that district alone only begins to illustrate the staggering odds that were against this constabulary force. ${ }^{131}$

It would be no surprise that by 1875 , several districts were demanding more African police to assist in the massive disparity between the police and the growing population. In many cases, applications were ignored or simply not given the amount requested. In April 1875, Captain Allison, the Administrator of Native Law at Oliver's Hoek, applied for extra funding for 14 "native police". ${ }^{132}$ In Victoria County, Oliver's Hoek remained an important throughway for the Drakensberg Mountains and the key point of security for the Tugela Division. Between 1861 and 1876, Victoria County's population (which included Tugela) ballooned from 18,762 to 56,117 . The vast majority of this increase was within the African population. ${ }^{133}$ With that in mind, it seemed obvious that six police which had been provided were simply not enough for the area. Although additional funding had previous been provided under "special payments", Captain Allison insisted that a more permanent fixture to the district's police force would be required "until such time as the force is reduced." ${ }^{34}$ No timetable for such reduction was provided, and the division would continue to have fourteen African constables well after the Anglo-Zulu War.

With such a high demand of African police during the 1870 s, it was no surprise that retention and compensation quickly became relevant topics for the magistracies who administered these constables. Because of the financial constraints of the colony, salary was not always easily increased. In the Inanda Division, also in Victoria County, the resident

\footnotetext{
131 To put such numbers in perspective, in 2012, South Africa's police force numbered 156,489, or roughly one policeman for every 315 people. http://www.saps.gov.za/

132 "Minute Paper: Administrator of Native Law Olivers Hoek applies for renewal of authority for present year for the employment of the 14 native police approved for in the Estimates," CSO 517, No. 1536, 1875.

133 Though 4,898 Indians resided in the county, the European population had only increased by from 1,155 to 1,700 during that period. "Population", Natal Blue Books, 1861-1876.

${ }^{134}$ Captain Allison to the Secretary of Native Affairs, April 10, 1875, CSO 517, No. 1536, 1875.
} 
magistrate saw the necessity for a re-examination of payment in the African constabulary. Arguing that at one time the African police were once paid $£ 15$ without rations, the magistrate reasoned that their pay should not be increased to 20 pounds, including their rations, as he claimed had been done the year before. ${ }^{135}$ Instead, the magistrate argued that such a system should only be implemented for the Indian, or "Coolie" constables within the district, who were described to be "dissatisfied considering they are less liberally treated". ${ }^{136}$ Interestingly, the magistrates estimates and those in the government Blue Books simply do not align. The magistrate argued that Indian constables receive $£ 40$ without rations, versus the $£ 24$ in the government estimates. Even more striking, African pay is only $£ 12$, and at no point before 1875 reached the $£ 20$ alluded to by the magistrate. ${ }^{137}$ Only $£ 12911$ s. 2 d. were allocated to clothing and rations for the police force, which could be part of the included "with rations" compensation. Again the magistrate for Inanda was not even considering raising the pay of the African police, but instead was concerned for how such pay methods would contend with the Indian constables, who were a considerable minority to their African counterparts in most of the districts of the colony.

Even by 1878 , when the members of the mounted police received a pay raise, Major Dartnell requested from the colonial government clarification of the issue of raising African pay, assumedly in the mounted police but presumably related to the African constabulary as a whole. ${ }^{138}$ Dartnell pointed out that though the scale of pay had been approved by the lieutenant-governor at the first formation of the force, "the rates have never been specified in

\footnotetext{
${ }^{135}$ Minute: Resident Magistrate, Inanda Division to Honourable Colonial Secretary, Pietermaritzburg, Natal, July 30, 1875, CSO 523, No. 2250, 1875.

136 Ibid.

137 “Revenue and Expenditures, 1875”, Natal Blue Books, 1875.

${ }^{138}$ Minute Paper: Auditors Query regarding additional pay for native policemen, July 2, 1878, CSO 631, No. $687,1878$.
} 
the Estimates". ${ }^{139}$ Dartnell was making specific reference to the Africans within the Mounted Police force, whose numbers were continuing to decline by the conclusion of the 1870 s. The arguments for such pay changes were considerably revealing to the view of African police pay in the colony as a whole. Dartnell once again made reference to the $£ 20$ per diem, but there was a general confusion about who was largely responsible for such decisions. One magistrate argued to the colonial secretary that while the increase to mounted police pay had been approved in June 1877 by the legislative council, it was only under the approval of the executive and legislative authority that "Native compensation" could be increased. This perpetual round robin of responsible for the African police force is indicative of a system reliant on the African police, but without proper oversight or direction. Even when clarified by the colonial government, the auditor was still left unsure of who had the proper authority and what actions would follow in such a case. Despite all of this debate, it does not appear that African police pay, rations, or tender were significantly increased.

No surprise, the colonial government was always seeking the lowest tender possible, and would consistently look for the cheapest option when supplying their African police. In most cases, however, the cost would be transferred to the police and be taken out of their related per diem to assist in absorbing the colonial government's cost. ${ }^{140}$ This explains why throughout the 1870 s, African police pay would remain stagnant at $£ 12$ for the majority of the rural constabulary. Ironically, it was the Inunda division which first made a major increase in pay, from $£ 12$ to $£ 24$, in 1880 . Even with the outbreak of the Anglo-Zulu War, pay for African constables would remain at $£ 12$ for the majority of the colony, the two exceptions being Inunda and Durban County, who paid some of their constables $£ 14 .{ }^{141}$ Again, this lack

\footnotetext{
139 Ibid.

140 "Forward tender for the supply of mealies and mealie meal for the Native Police at Ulundi during 1877", CSO 594, No. 1827, 1877.

141 “Establishments", Natal Blue Books, 1871-1880.
} 
of proper compensation or increase in pay was indicative of a racialized system of control, which the African willingly participate in, ostensibly due to the opportunities in being part of the colonial government, as opposed to a labourer or servant for the rest of the colonial population. While disparities in pay are a commonalty in the use of indigenous troops, the glaring omissions for the improvement of the African police in the rural regions remain indicative of Natal's continued attempts to grasp with the issues of cost and control during the formative period.

\section{"A Guard, not a Constable"}

The use of the African police in the safety and security of the colony of Natal was the product of cost saving measures. This was even more evident in the versatility the African police show within Natal's defensive institions. Despite their importance to the maintenance of law and order within the colony of Natal, for many in the colony the African police were seen as little more than a glorified guard for the colonial gaol systems. The evolution of the gaol system within the colony of Natal has already been partially discussed, yet for the majority of the rural regions of the colony of Natal, few districts or counties had any officials working for the prison beyond one gaoler. This meant that the apprehension and guarding of these prisoners within each district fell to the constabulary, particularly the African constabulary. As early as 1852 , African police were responsible for the apprehension and guarding of prisoners within Natal penal system. Two particular cases from Ladysmith and Weenen are most revealing to this duel role encompassed by the African police.

In August 1852, the resident magistrate of the Klip River Division at Ladysmith, Captain Johan Herman Marinas Struben, expressed his growing concerns to the colonial government of the number of prisoners that were building up in his district. Because of the lack of a gaol, the necessity was increasing "daily" since a number of white and black 
prisoners were already in the custody of the police "who require proper supervision."142 This proper supervision, in Struben's mind, was ostensibly due to the Klip River only having two European constables and eight African constables. Struben's primary concern was not the lack of proper guards or facilities, but instead a lack of direction from the colonial government. Though Struben was well versed traveller of the world, and a native of Holland, he had no experience in South Africa, and had only been magistrate since $1850 .{ }^{143}$ Struben was forwarded a copy of the Pietermaritzburg prison rules by the colonial government, but the apprehensions Struben exhibits in his letter was not alleviated by the African constables at his disposal, despite their success in apprehending 36 prisoners over the course of the year in 1852. The police were only able to hold six prisoners in their single makeshift cell and only held 12 prisoners at one time during the course of the year. ${ }^{144}$ Without a proper gaol, however, escapes were not unheard of. The same month Struben extended his concerns to the colonial government, a person of interest named "Umbelekela" escaped custody as the African police attempted to capture another suspect, "Induvaan". ${ }^{145}$ Since "Umbelekela" had already provided a statement in April related to a murder taking place beyond the colony, his escape was not seen as a major catastrophe, but instead the failure of the African constabulary to capture "Induvaan" was emphasized. The lack of a gaol, however, remained a glaring issue for Ladysmith.

Not all magistrates were content with their situation regarding prisoners and gaols. In Weenen, the magistracy also lacked a gaol, meaning alternatives to prisons needed to be

\footnotetext{
142 Resident Magistrate, Ladysmith, to the Acting Secretary of Government, August 16, 1852, AGO I/8/2, $56 \mathrm{~A} / 1852$.

${ }^{143}$ Guy describes Struben as a "crook and a bully" who was both feared and hated by the Africans, as he took the Afrikaner line that no Africans were native to the country. See Guy, Theophilus Shepstone and the Forging of Natal, 167-168.

144 "Gaol and Prisoners", Natal Blue Books, 1852.

${ }^{145}$ Henry Fuller, Clerk of Peace Ladysmith, to W. Harding, Crown Prosecutor, Pietermaritzburg, August 25, 1852, AGO I/8/2, 58A/1852.
} 
considered. By 1852, Weenen, which had no capacity or records for prisoners, was a newly declared district and did not have its own constabulary until 1854. In light of this, when a white prisoner was being held for selling guns to the African population, Arthur Hawkins, Assistant Resident Magistrate at Weenen, having "no white constable and no place of confinement" saw it necessary to send the prisoner to Pietermaritzburg in the "charge of [Hawkin's] native policeman." 146 Again, the lack of manpower and resources forced the African police to perform the service of transporting prisoners throughout the colony. Not surprisingly, even as the colonial government and police institutions improved over the next decade, it remained more and more difficult to differentiate these functions of the African constabulary with those of the prison system.

Prisoner escapes did not decline over the ensuing decades. Despite an increase in the number of gaols, the overall number of constables did not significantly increase and new districts were slow to establish new gaols. Though there was a greater sense of responsibility for such actions from within the colony, prisoner escapes, especially by Africans, were looked on as a combined problem with the constabulary and the prison institutions. Such was the case in the Newcastle Division. Established in 1864, the Newcastle Division was one of the northern most districts in the colony. Isolated and with a large Afrikaner population, it was the source of contention for parts of the colonial period. ${ }^{147}$ It was no surprise than that the division experience problems with prisoner escapes during its early years in the 1860 s. In June 1867, an African prisoner escaped while in the custody of two African police. The police, instead of holding the prisoner at the magistrates office, decided to rest in a local kraal five miles from the office with the intention of arriving the next day. During the evening the prisoner somehow removed his handcuffs, successfully knocked out one of the police "with

\footnotetext{
${ }^{146}$ Arthur Hawkins, Assistant Resident Magistrate, Weenen, to the Crown Prosecutor, Pietermaritzburg, March 2, 1853, AGO I/8/2, 7A/1853.

${ }^{147}$ See Newcastle's request for assistance from Natal Mounted Police in Chapter Four: European Police.
} 
an iron bar" in the scuffle, and made his escape. ${ }^{148}$ The magistrate reported that he had a number of police still looking for the escapee, but was doubtful of the prisoner's recapture. Interestingly, the magistrate's first comment on the cause was not the failures of the African police but instead a reminder that he had a "total absence of all means of securing criminals." 149 Had there been a gaol, the magistrate believed that in all probability the prisoner would not have escaped "as the constables in charge would have lodged [the prisoner] safely instead of remain in at the huts." ${ }^{150}$ Until a gaol was constructed, the magistrate believed that escapes would continue to occur, especially for those of "very bad character". ${ }^{151}$ The fault did not lie with the African police, as it was seen as "improbable to watch prisoners night and day for a length of time." 152 This was not only the case for African prisoners. Even with white prisoners, the difficulty of holding them was even greater. But this was, in the magistrate's opinion, because he possessed only one white constable "who had numerous duties to perform." 153

Despite the main complaint being the lack of a gaol from the magistrate, the response from the colonial office was not a promise of more funding, a new gaol, or even another European constable. Instead, the lieutenant-governor, after being informed of the escape, asked for more details on the two African constables responsible for the escape and "whether the constables have been dismissed or otherwise punished." 154 Whereas promises for additional funding would be unexpected, the government's response to immediately blame the African constables is telling to the role of Africans within the police hierarchy. The

\footnotetext{
${ }^{148}$ Resident Magistrate, Newcastle to the Acting Attorney General Natal, June 11, 1867, AGO I/8/9, 292A/1867.

149 Ibid.

150 Ibid.

151 Ibid.

152 Ibid.

153 Ibid.

${ }^{154}$ Colonial Secretary to the Acting Attorney General, June 28, 1867, AGO I/8/9, 291A/1867.
} 
magistrate at Newcastle believed the problem of escaping prisoners to be linked to the lack of gaols, yet he admitted only using his white constable to escort white constables. The Newcastle Division had six African constables to the one European constable. With a population of 8,929 , this illustrated a lack of proper resource implementation, considering the police to population disparity was less extreme compared to the Inunda Division as discussed above. ${ }^{155}$ In the end, the tactic was not unique to the colony as a whole, as specific reference was usually made to the attorney general of the escort of European prisoners by European constables. ${ }^{156}$ But as late as 1872 , Newcastle remained gaol-less, and the African constables presumably continued to either hold prisoners themselves, or transport them to the county gaol in the Klip River division. In larger districts like Durban and Pietermaritzburg, which had gaols with sizable staffs, there were clear distinctions between guard and constable. In a telegraph the same year as the Newcastle incident, the clerk of peace for Durban corrected the attorney general at Pietermaritzburg, informing him that a Mr. Johnson was "only one of the guards appointed over the convicts and not a constable."157 Such distinctions were rarely necessary in the more rural regions of Natal.

The constabulary, especially in districts without an abundant source of manpower, were used for actions beyond the simple guarding of prisoners. Tax collection, though largely in the purview of the resident magistrate, could and would be transferred to the African constabulary when necessary. Even by 1876 , the colonial government clarified that in the case of transporting the "Specie" or hard money from the magistrate's office to the Treasurer of the Colony, it must be brought by "European or Native Constables... by public

\footnotetext{
155 "Return of the Population", Natal Blue Books, 1867.

${ }^{156}$ One example was the specific reference of the European Constable in the transport of a prisoner Hilliard from Durban to Greytown the same year as the Newcastle incident. Colonial Secretary to the Attorney General, November 20, 1867, AGO I/8/9, 513A/1867.

${ }^{157}$ Natal Electric Telegraph, Pietermaritzburg Station: Clerk of the Peace Durban to Attorney General, Pietermaritzburg, September 25, 1867, AGO I/8/9, 439A/1867.
} 
conveyance, special vehicle, or pack horse." ${ }^{158}$ There remained some apprehension about the transport of such sums by the African police from those within the colonial government. In the debate over the workings of the language of the referendum the Treasurer's concern was that in cases of the sum exceeding $£ 200$, the package should be taken by two African policemen, seemingly due to anxieties over the temptation of such a large sum. ${ }^{159}$ In the final document, however, there was no special mention of the sum or number of Africans necessary for the transport of the "specie". It was seen as unnecessary by the colonial secretary. This does not reveal an overabundance of trust for the African population, but instead perhaps a view of necessity in the colonial documents, or perhaps even outright languor. When facts and information could be perceived as critical, as with the escape of a convict, the opinion or the reporting of the African police or guards were almost insignificant. Such was the case in 1872 when the resident magistrate of Durban saw it unnecessary to take the deposition of a "native guard" who had secured the prisoner. ${ }^{160}$ While the reasoning behind such an omission rested on the fact that the prisoner had already admitted to the escape, even the clerk to the resident magistrate felt that it might be necessary to conduct the interview, though he "did not push the point." 161 The word of the African was not dismissed, but simply seen as unnecessary.

This lack of inquiry was not always the case, as more in depth investigations into prison escapes did exist in the latter formative period of the colony of Natal. One particular case in the Upper Tugela Division even made a more balanced attempt to cast blame on either the European or African constables. In July 1876, 12 men were arrested and sentenced to two months imprisonment for living amongst the AmaNgwani (Swazi or Ngwani) without passes

\footnotetext{
${ }^{158}$ Regulations: Transmission of Specie Other Than Hut Tax, April 17, 1876, CSO 543, No. 465, 1876.

${ }^{159}$ Minute Papers, CSO 543, No. 465, 1876.

${ }^{160}$ J.P. Waller, Clerk to the Resident Magistrate, Durban to Robert Isaac Finnemore, Clerk to Attorney General, January 30, 1872, AGO I/8/14, 46A/1872.

161 Ibid.
} 
or having property reported themselves the chief or local magistrate. ${ }^{162}$ On August $21^{\text {st }}$, the prisoners broke out of the gaol hut, seized a number of knobkerries and sticks and fled from the district, with nine of the prisoners successfully escaping. Though such escapes were typical within the colony, even in the case of magistracies with access to a gaol, the colonial government and magistrate's response to the incident is perhaps most telling to the internal dynamics of the police institutions within the colony.

All three African police, the European constable and gaoler William Wardell, and the resident magistrate gave depositions to the incident. The most descriptive statements were provided by the three African constables, who described the escape taking place shortly after supper was served, with the prisoners going directly for the hut that housed the weapons, under the false claim they were look for "dukku" (described as "native tobacco"). Two of the constables gave pursuit, while another constable attempted to block their path. Interestingly, though armed with assegais, Mahmpo, one of the African constables, initially tried to hold the escaping prisoners off with his knobkerrie, until it was taken from him and he was forced to use his assegai as he was surrounded and "fought for [his] life."163 Mahmpo wounded one prisoner, but was lucky to survive the encounter with the now armed escapees. Constable Wardell did not take part in the scuffle, but did claim to raise the initial alarm that the prisoners were attempting to escape. Oddly, it was the resident magistrate who gave the order for one of the police, Bambini, to "alarm the people of the kraals" of the escape and seek assistance in recapturing the prisoners. Wardell contended that he only remained behind to look after the five remaining prisoners. ${ }^{164}$ Another prisoner was captured shortly after the escape, but the remaining nine were not immediately found. At the time of the magistrates

\footnotetext{
162 These men were described as "AmaNgwazi" though it is unclear if this is simply confusion with the Swazi. A. Allison, Resident Magistrate, Upper Tugela Div, to the Honorable Colonial Secretary, September 26, 1876, CSO 562, No. 2301, 1876.

${ }^{163}$ Statement of Mahmpo before Resident Magistrate, August 22, 1876, CSO 562, No. 2301, 1876.

${ }^{164}$ Statement of William Wardell before Resident Magistrate, September 21, 1876, CSO 562, No. 2301, 1876.
} 
report, there was full confidence they would be captured closer to Ladysmith with the assistance of the secretary of native affairs (likely part of Shepstone's African units who were called upon for such occasions). Though the situation was more violent than many other prison breaks, the questions from the colonial government quickly turned to blame. The government wanted clear answers from Allison on whether the European or African constables were to blame and why such a failure of security took place.

Allison and the constables' response were remarkably reserved. Allison acknowledged that only three of six African constables were present the night of the escape. One had been granted permission to take a leave of absence to his kraal, but the other two were on duty, one in pursuit of a cattle thief and the other on "border work" delivering a message to a local chief requiring him to report to the magistrate. Since he considered the gaol well secure with the four remaining constables, Allison doubted that the escape was due to "any lack of vigilance on the part of either the white constable or the native police."165 Even Constable Wardell stated that he "didn’t think the Native Police were to blame."166 Constable Baunlu, who pursued one of the prisoners to a nearby kraal and struck him with his knobkerrie, casts no blame at all, and only systematically reported his part in the prison break, telling that though he left the man he struck prostrate on the ground, he "did not see this man again." 167 The fact that none of the individuals involved, either white or black, were willing to cast blame on their fellow constables is revealing to the deeper dynamics that existed in rural regions of the colony. There appears a greater sense of comradery within these rural constabularies, possibly due to the level of isolation experienced by the European members of the police. When there was only one European constable in a county, they

\footnotetext{
165 A. Allison, Resident Magistrate, Upper Tugela Div, to the Honorable Colonial Secretary, September 26, 1876, CSO 562, No. 2301, 1876.

${ }^{166}$ Statement of William Wardell before Resident Magistrate, September 21, 1876, CSO 562, No. 2301, 1876.

${ }^{167}$ Statement of Baunlu before Resident Magistrate, August 22, 1876, CSO 562, No. 2301, 1876.
} 
became more reliant on their African colleagues, creating a possibly less racialized working dynamic. Though the colonial government sought blame, and requested further information on why the white constable did not take part in the pursuit, the matter was eventually put to rest by both the lieutenant-governor's office and the attorney general. Much like the Newcastle escape of 1867 , the seeking of blame seemed to be largely a formality, as there was every indication that the escapees would eventually be recaptured, and serve the remainder of their sentence. Though the incident was dramatic, it was the outcome of an overstretched police force dealing with a major influx of prisoners. Even Allison contended in his initial report that the gaol typically housed only six to eight prisoners versus the 18 at the time of the escape and that it was this influx and not "the insufficient [number of] guards [which] led to this most impudent and defiant act."168

What these incidents and regulations indicate is that the role of the African constabulary, though important, was largely amorphous in many parts of the colony of Natal during the formative period. Limitation to resources and the police force as a whole contributed to escapes and concerns over the transport of money, supplies, and prisoners. Because they were typically the only manpower available, the African police were forced to perform actions that were beyond their purview. But because they acted as an important and competent component in Natal's colonial defence, they continued to be called upon to perform such services, whether appreciated by the colonial government or not. The issue of blame for escapes and concerns for theft were present, yet it is perhaps most impressive that those who worked closest with the African police were usually the ones to defend their positions in the colony and deflect blame when instances of disrepute took place.

\footnotetext{
${ }^{168}$ Minute: Resident Magistrate of the Upper Tugela Division to the Honourable Colonial Secretary, Natal, August 23, 1876, CSO 562, No. 2301, 1876.
} 


\section{A Model for the Future}

With the changes in policy and formation of the police in the $1870 \mathrm{~s}$, the African constabulary and police forces solidified their role within Natal's defensive structures. Though organized African police forces in Natal did not take an active role in the battles of the Anglo-Zulu War, it is very possible that members of the constabulary were recruited into the Natal Native Contingent or other levy organizations during the war. ${ }^{169}$ Though their contribution to colonial defence during the war was marginal, the African police did provide the groundwork for later inspiration within and beyond the colony of Natal.

Perhaps because of the success of the African police forces in the colony, the good showing of the mounted police, or the recent influences created by Shepstone during annexation, the Transvaal sought assistance in the formation of their own "native police force" in the summer of 1878. Lieutenant Lleweleyn H. Lloyd of the Transvaal Native Police contacted the colonial secretary of Natal in June about the possibility of "obtaining permission to recruit men from this Colony [Natal] for the Transvaal Native Police."170 Presumably the success of the Natal African police institutions was a factor in Lieutenant Lloyd's request, but he was also limited in his available resources and viewed the Africans who had lived under British rule for several decades to be more probable candidates for police work than those who had lived under Afrikaner rule.

The point of contention for the executive council, however, was the concern that such a corps would be raised as "an armed military force to be used in cooperation with European troops, or otherwise in active service." ${ }^{171}$ Because of the military concerns within the Transvaal and the possible impending conflict between the Afrikaner, Zulu, and British, this

\footnotetext{
169 See Chapter Six: African Military Units.

${ }^{170}$ Lieutenant Lleweleyn H. Lloyd, Transvaal Native Police to the Colonial Secretary, Martizburg, June 22, 1878, CSO 647, No. 2250, 1878.

${ }^{171}$ By Command of His Excellency [the Lieutenant Gov.] in Council, July 7, 1878, CSO 647, No. $2250,1878$.
} 
was a probable conclusion. The lieutenant-governor had not objections to the Africans being “engaged in purely police purposes", but quested the viability of an armed African force within the Transvaal. ${ }^{172}$ Though it remained unlikely that Africans were recruited for the Transvaal Native Police, considering the outbreak of war was only two years off and the growing tension over the Transvaal border and the Zululand continued to be a growing concern, the fact that Natal was requested to provide Africans for the police force was particularly telling. Though the racial tension created by Africans arresting Europeans would be even greater in the Transvaal, the fact that the indigenous Africans of Natal were considered a viable source of police labour illustrates the growing or at least existing reputation of African service. ${ }^{173}$

African participation in the Natal police institutions did not dissipate following the Anglo-Zulu War. In fact, by August of 1882, there was a greater formalization of the African police after the formation of the "Select Committee appointed to report upon the question of the Formation of a Native Police Force". The committee concluded that it would be beneficial for the colony as a whole to form a "Native Police Force of 200 men... To act as a Police within the Colony, for patrolling the country, visiting farms, estates, and Native locations...preserving the peace...prevention and detection of crime, and of apprehending criminals and offenders and suspected persons." ${ }^{174}$ The force would be raised from volunteers and "not by the exercise of direct or indirect pressure upon Native chiefs to obtain men." ${ }^{175}$ In

\footnotetext{
172 Ibid.

173 Though the Transvaal was looking for a more military than police unit is also an important note, the role of Africans in Natal's military institutions and their reputation will be examined in Chapter Six: African Military Units.

174 "Report of the Select Committee appointed to report upon the question of the Formation of a Native Police Force, Legislative Council, No. 12, August 4, 1882," The Natal Government Gazette, August 8, 1882.

175 This clarifies an important component of the recruitment process for the police. Though there is little evidence that Europeans actively forced Africans to serve in the police in Natal (hence their volunteer nature), it is possible that chiefs pushed their subjects into joining such institutions, either as a means of tribute or an opportunity to have direct contact and possibly control over local police establishments. Further study is necessary to reveal this possibility. Ibid.
} 
light of this, no more than four or five men from each "tribe" were permitted to enlist. In turn, the Native Police would have only white officers, who were primarily responsible for the discipline and application of law within the African forces. The officers were also recommended not to use their horses when drilling the police and were given free rein to search all kraals within the colony. A strong departure from previous precedence, the dwindling influence of Shepstone and his system of influence over the chiefs of the colony was finally having an impact on policy, Africans were sought who had only one loyalty; to the colonial government. An emphasis on a station system, similar to some extent to the traditional European police posts, was established, in which a station would consist of two huts for the men, one hut for the Europeans, one hut for horse and stores each, and all surrounded by a wall. It was made clear that in not case would station be left without at least one man, despite the demand for police and officers to travel extensively throughout the country.

Even with these numerous changes and reforms which had been called upon by the colonial government and European population, many of the fundamental flaws within the African police systems would endure. There remained a divide between the urban and rural segments of the colony, as the police force was expressly "not raised for service in towns... [and] no station ought to be place in or within seven miles of a town or village; and if any member of the Force resorts to a town or a village, he should report is reason for doing so." 176 Again, the "the invisible boundaries of the town lands" persisted, preventing the full implementation of the police force in the colony as a whole and demonstrated the continued express purpose of the Native Police in the administration of law in the predominantly African rural population. ${ }^{177}$ The continued division between rural and urban was fuelled by

\footnotetext{
176 Ibid.

177 "Have we, or have we not, security for life and property in Natal?", The Natal Witness, April 22, 1873.
} 
the growth of the white population, but also the racial division of the colony as a whole. The attempt to "whiten" the police force in the towns was a continuing response to European fears of the African within Natal. This continued racial view was perhaps the most striking when examining the continued discrepancies in pay that existed in this new police.

Despite the colonial government investment of $£ 6,500$ to this new police force, the annual pay for the African police remained only $£ 12$. Though rations and uniforms were included in addition to this pay, there remained a massive discrepancy between the pay of Africans and their white counterparts. To make these matters even worse, five officers of this force earned an average of $£ 266$, with the captain earning $£ 400$ alone. ${ }^{178}$ Though not mentioned in the yearly defence report for 1883 , it is telling that one of the major concerns for defence committee was that the mounted police force's pay was "much below the pay and allowances to officers and men of the following Corps: the Royal Irish Constabulary, the New South Wales Police Force, the New Zealand Armed Constabulary, and the South Australian Police."179 This concern for the police force presumably only encompassed the white members, as the police still retained some Africans in their ranks by 1883 . In the grand scheme of colonial defence, the nearly unchanged pay for the African police over a decade and a half remains telling of the perception of African versus European police in the safety and security of Natal.

\section{Conclusion}

Despite these contradictions, reforms, and ignorance of past problems, the African police institutions within the colony of Natal retained an important place in the development of Natal's structures of colonial defence during its formative period. The organization,

\footnotetext{
178 The Natal Government Gazette, August 8, 1882.

179 "Report of the Select Committee appointed to consider and report upon the general question of Defence and Police Force throughout the Colony, Legislative Council, No. 21, August 28, 1883," The Natal Government Gazette, September 4, 1884.
} 
implementation, and response to violence which permeated the African constabulary acted as an important pillar in understanding the fluid development of colonial Natal. Sadly, though many examples of African agency can be found during this period, there remain too few examples of the African voice in the development of Natal's police institutions. Though the role of Africans in police institutions remains a growing area of research, developing a deeper understanding of African viewpoints and perceptions continues to elude us. ${ }^{180}$

Practically, there were many reasons for using African police. Given the racial hierarchy in Natal, they were cheaper in terms of salary and uniforms. Also, they knew the local Nguni languages and could easily move amongst the African community. This was difficult for most Europeans as they were in a minority and thus could never completely dominate the rural police. The use of Africans as colonial police, nevertheless, moved beyond simple convenience, to instead address a deeper psychological response to Empire by the British. Yet their place within Natal's colonial structures remains somewhat amorphous. Though not part of Shepstone's direct military systems (see next chapter), and presented as peripheral to the support of the white constabulary, or dismissed outright in the formation of new systems like the Natal Mounted Police, the African constabulary remained a consistent, enduring, and overall successful element of the defensive structures of Natal's formative period.

\footnotetext{
${ }^{180}$ Some historians have attempted to look at new types of analysis, such as Mokoena's examination of "Zulu" or "Native" Police's presentation in photography, and ideas of service, collaboration, and an economy of consumption in late nineteenth and early twentieth century Natal. See Hlonipha Mokoena, "Anonymity and the Zulu Policeman : An Economy of Portraiture” (WISER Seminar (Wits University), July 2013).
} 


\section{Chapter Six: African Military Units}

\section{Introduction}

In October 1855, there was a panic within the colony of Natal over the possible invasion of the Zulu King Mpande. Like previous panics, an invasion from Mpande never materialized, despite considerable apprehension from within the colonial population. Even without any real threat, the population of Natal, both white and black, remained fearful of impending invasions. As has already been discussed, such apprehension and fear was nothing new, but a typical feature of the formative period of the colony. Advocates for changes to the military system, including contributors to the Natal Mercury like "One of the People", envisioned the creation of guerrilla or volunteer corps composed of men who understood the territory of the colony, as well as the tactics and traditions of the indigenous African groups, without being "tied down by precedent or the rules of inapplicable English military tactics." The writers of such editorials, however, touted the necessity of such white, European organizations in light of a growing fear of the African population. As has been previously illustrated, the colony focused on the creation of volunteer corps and European mounted police as a response to several of these concerns. In many cases, these advocates largely neglected or marginalized the presence of the indigenous population and their role in the defence of the colony. Much like the previous chapter on African police, this chapter will address the impact of indigenous military units on the security and organization of the British colony of Natal during its formative period. The importance of these indigenous military units on the safety and security of the colony is undeniable in the broader examination of Natal's history, yet questions remain on how these units where organized within the colonial system, what were their origins in the formation of the colony, how were they perceived by

\footnotetext{
${ }^{1}$ The Natal Mercury, October 25, 1860. See Chapter Three: Volunteers, p. 77-87, for further analysis of the suggestions for reforms of the white military systems of the colony.
} 
European colonists, and in what manner did these military institutions change during this period.

Indigenous involvement in the security of the colony, as was the case of the volunteer corps, advances the theory of a type of militarization of society that took place in Natal during this period. More importantly, it also provides a viable platform for incorporating African agency into the administration and creation of Natal as a colonial state. The use of African military units, however, would continue to inspire the same debates, reforms, and missteps as their counterparts in the other defensive institutions of Natal. Yet, it can be argued that these African military units were possibly the most successful, enduring element of colonial security during Natal's formative period.

Although the African police institutions of the Natal were important to the scope of colonial defence, it was the African military institutions that were established within the colony that facilitated the overall security and peace that was praised by Shepstone in his later years. ${ }^{2}$ By the conclusion of Natal's formative period, African military institutions were nothing new in the British Empire. Even V.G. Kiernan made the astute observation that the "prize of empire has always been a supply of colonial soldiery" which would typically be cheaper and, in the British mind, drawn upon the warlike elements of some indigenous societies. ${ }^{3}$ Nevertheless, this dissertation's analysis of the role of colonial troops within the formation of empire must challenge existing perceptions of colonial troops that have entrenched themselves within some aspects of the historiography. Though some would argue "the African soldier was proud to serve" within the Empire, this willingness to serve by the

\footnotetext{
${ }^{2}$ See Introduction for Shepstone's claim of Natal's "Forty-six years of existence, and forty-six years of peace". ${ }^{3}$ V.G. Kiernan, "Colonial Africa and Its Armies," in War and Society: A Yearbook of Military History, 2 (London: Croom Helm, 1977), 20.
} 
colonized people has been somewhat exaggerated. ${ }^{4}$ Many of these perceptions were formulated from the observations and writings of former British officers that has permeated the early historiography of the colonial troops. This includes one British Army officer's observation that: "For drilling and parade the native mind shows great keenness and aptitude...Smart and well-disciplined they are most punctilious in any military service." These arguments also espoused the benefits of colonial rule, especially when some maintained that army service would possibly have a "detribalising influence" and the tactics of divide and rule "might be practised between army and people, as well as between soldier and soldier" with examples including the West African Regiments in Freetown, Berbers against Arabs in Morocco, or Fula tribesmen against rebels in Guinea. ${ }^{6}$

These observations, however, do nothing to assist in creating a greater understanding of the role of Africans within colonial rule. Broadly speaking, the first institutions to be established in a colonial territory were usually a "uniformed, armed, and disciplined force of soldiers", with Africa and particularly Natal being no exception. ${ }^{7}$ This is predominantly why the concerns for security were so important to the early colonial settlers of Natal. A military presence was critical to the creation of this sense of security in the colony. Imperial troops, though stationed at Ft. Napier and a legitimate representation of colonial authority, were only a final measure in the prevention of the colony from being taken over by an outside, aggressive force, whether the Zulu Kingdom, the Orange Free State or South African Republic, the Xhosa forces in Kaffraria, or, less likely, the encroachment of imperial rivals.

\footnotetext{
${ }^{4}$ Of course many of these perceptions were perpetuation by non-academic sources, with a clear fondness for the past, including Lunt's lamentation at the end of empire that British colonial officers were "the modern equivalent of the Roman legions recalled to Rome in the dying days of that empire, who probably bored their friends as they reminisced far into the night about faraway places." See James Lunt, Imperial Sunset: Frontier Soldering in the 20th Century (London: Macdonald, 1981), 173.

${ }^{5}$ Quoted in Kiernan, "Colonial Africa and Its Armies,” 25.

${ }^{6}$ Ibid., 34.

${ }^{7}$ Killingray and Clayton, Khaki and Blue, 145.
} 
Despite all this, Britain needed African troops in some form to defend its territory, as was the case within much of the Empire.

As Ann Laura Stoler and Frederick Cooper observed, colonial control "depends on soldiers who were simultaneously coerced and coercing, who enforced the will of the elite yet made demands themselves." institutions that existed across the Empire. But more important, as was the case in Natal, colonial military service, to be properly understood, must be examined beyond a simple enthusiasm to serve, but instead take into account the diverse social context of the African experience. ${ }^{9}$ Parsons rightly argues that much of the research dealing with British colonial Africa has been unconsciously influenced by the bias of mistaking the discipline of African troops for either loyalty or collaboration. Instead, African troops should be examined in the same complexity as their white counterparts, who were divided by ethnicity, education, military specialization, and territorial origin. Though Kiernan's argument that "Native forces" could also be used for tasks that Europeans "might feel squeamish about", the use of Africans in segments of Natal's military system was largely out of necessity and not convenience. The white manpower within the Colony was simply incapable of providing the adequate forces necessary to oversee the massive colonial population, both white and black. ${ }^{10}$

Unfortunately, unlike Parsons' account of the KAR or Stapleton's examination of the Rhodesian African soldiers, the nineteenth century does not provide nearly enough context

\footnotetext{
${ }^{8}$ Frederick Cooper and Ann Laura Stoler, Tensions of Empire: Colonial Cultures in a Bourgeois World (Berkeley: University of California Press, 1997), 24.

${ }^{9}$ Such an analysis is nothing ground-breaking, as Parsons observes in his analysis of the King's African Rifles (KAR) and Britain needs for African soldiers to maintain its authority in East Africa. See Timothy Parsons, Social Implications of Colonial Military Service in the King's African Rifles, 1902-1964, The African Rank-andFile (Portsmouth, NH: Heinemann, 1999).

${ }^{10}$ V.G. Kiernan, Colonial Empires and Armies 1815-1960 (Gloucestershire, UK: Sutton Publishing, 1998 ), 161.
} 
for the African soldier. ${ }^{11}$ The African military units of Natal only exist in the periphery of government documents, and are either ignored, or the product of criticism within the press. When suggestions for greater formalization were put forward, they were denied, ignored, or outright dismissed. This is particularly why this history does not fall within the main categories of military histories in Africa outlined by Killingray. ${ }^{12}$ Because of this, it is hard to define the Africans within Natal's defensive institutions as part of the "labor aristocracy" that emerged within colonial society during the period of European rule. ${ }^{13}$ Because the military organizations were a part of the already formalized African military systems, they were not required to be a "Europeanized" component of Natal's system of colonial defence.

It should be remembered that African perceptions of military service throughout the Empire were determined largely by the degree to which military institutions transformed and reordered their daily lives. ${ }^{14}$ In Natal, there was no formalized military army or unit composed of Africans until after the Anglo-Zulu War. Plans were put forward, as this chapter will illustrate, but nothing took place resembling the uniformed African defending the Empire that became part of the popular imagination during the twentieth century. Nevertheless, Africans did serve as an important component in colonial rule, especially in the form of military actions taken during this formative period of the colony. The contributions of Africans, however, were not consistent and changed within the debates over defence in the colonial government and within the press during this period. Even the identification of the

\footnotetext{
${ }^{11}$ Both examine the development of these military institutions during the twentieth century. See Parsons, Social Implications of Colonial Military Service in the King's African Rifles, 1902-1964; Stapleton, African Police and Soldiers in Colonial Zimbabwe, 1923-80.

${ }^{12}$ Killingray argues the histories can be divided into four groups: "outline regimental histories, accounts of wartime campaigns, studies of specific aspects of West African military history, and the numerous and seemingly never-ending stream of studies of the modern armies of the independent West African states." Killingray and Clayton, Khaki and Blue, 147-148.

${ }^{13}$ In this case, I take Parsons definition of "labor aristocrats" as "a class of skilled and educated African workers whose expertise was needed to run the colonial economy." See Parsons, Social Implications of Colonial Military Service in the King's African Rifles, 1902-1964, 5.

${ }^{14}$ Ibid., 104.
} 
"Zulu" as a "martial race" would be altered in relation to changes in the economic and ethnic makeup of the colony during this period. ${ }^{15}$ To better understand this focus on "martial race", it is first critical to understand the makeup of the most influential military institution which existed in the Natal region prior the British colonial rule.

\section{An African Political Revolution}

Well before the organization of indigenous military forces under the British, there was already a military and political revolution that took place in the early nineteenth century in the Natal region, centred around the ideas of specific loyalties to chiefs based on the Zulu system of rule. The cause of this change can be linked directly to the rise of the Zulu nation under Shaka, and the military expansion and forced migration that resulted from said rise. Shaka, and his predecessor Dingiswayo, were the key implementers of a revolution in policy and used it to great advantage in territorial expansion during the mfecane. ${ }^{16}$ It was the manner in which military settlements, or "heads", were used by the Shaka regime that led to greater organization, categorization, and order within the Zulu kingdom and the greater Zululand region. The indunas, as both a commoner appointed by Shaka and the leader of each "head", were given considerable power and influence within Zulu society. Because the army and its impi regiments were the central unit of administration within Shaka's kingdom, it also acted as means to develop and solidify power within the central government. The military acted not only as the conduit for territorial expansion, but also as system of loyalty that rested with the indunas and ultimately Shaka.

The organization of the army, and the manner in which conquered peoples were incorporated into this system, provided a primary means of assimilation within Zulu society. Because the indunas were held in the traditional positions occupied by territorial chiefs, there

\footnotetext{
${ }^{15}$ Such changes were no unique, and can also been seen in Parsons' examination of the KAR. Ibid., 53.

${ }^{16}$ See Chapter Two for more details on the historiographic debate regarding the mfecane and the difaqane.
} 
is a clear transition from the bureaucracy of "royals" to a more effective administrative system with power in the hands of the commoners. ${ }^{17}$ The typical composition of African groups within Natal and Zululand was organized according to a patriarchal system of society, beginning with the head of the family, moving to the head of a kraal or small village, to the head of several kraals led by one induna, eventually to a Chief of the group or inkosi. ${ }^{18}$ The power of the chiefs was nearly absolute, and was quelled only by the limitations to their own military, and access to cattle as payment. Only strong, charismatic leaders such as Shaka, and later Cetshwayo, seemed capable of maintaining order and expanding Zulu power. Within Natal, estimates suggest that around ninety four different indigenous groups, or "tribes" as described by the British, existed within the territory of the colony before the arrival of the Afrikaner and even before the wars of Shaka. ${ }^{19}$ The claims made by the Afrikaner that Natal was essentially an abandoned land dismissed this history and attempted to remove any African claim that existed over what would become the colony of Natal. Such policies came to an end to a large extent following the British annexation of Natal in 1844 , though there remained considerable tension between the British and Afrikaner over land claims for decades to come.

It is important to make clear that though these diverse indigenous groups were commonly identified as "Zulu” by Europeans, their ethnic diversity is unquestionable. All

\footnotetext{
${ }^{17}$ J. D. Omer-Cooper, The Zulu Aftermath: A Nineteenth-Century Revolution in Bantu Africa (Evanston, Ill: Northwestern University Press, 1966), 171-172. Omer-Cooper such developments could be linked to the parallel occurrences within Europe as society moved away from feudalism and into a more administrative system.

${ }^{18}$ During the time of British rule in Natal, the Lieutenant-Governor was given the title "Head Chief" or "Chief of Chiefs" to indicate his authority over the other indunas. See "Questions proposed by his Excellency the Lieutenant-Governor and Answers by the Secretary of Native Affairs, October 16, 1863," Papers Relative to the Native Affairs in Natal, CO 879/2/6, 1863.

19 The presence of these groups in Natal before the arrival of the Afrikaners in 1838 remained a contentious issue, though evidence from individuals like Shepstone shows a considerable amount of evidence that these groups did exist in the colony before 1838. "Tribes which occupied the Territory now forming the Colony of Natal during the time of Dingiswayo's Father Jobi, and before they were broken up by Shaka's Wars," Papers Relative to the Native Affairs in Natal, CO 879/2/6, 1863.
} 
were part of an Nguni tradition which characterized the region, but to vacuously describe all Africans in Natal as "Zulu" would be an insult to the cultural and ethnic traditions of the people there. That is why for this chapter (and for much of this dissertation), the indigenous people of Natal are referred to as "Africans" or their specific ethnic designation. One can see a commonality in the military traditions of the people of Natal with those under the control of the Zulu during the mid-nineteenth century. Similar comparisons could be made between the Ndebele or Sotho of the region as well. This is why the military revolution of the Zulu matters. Far from espousing the "martial race" theory, this military revolution's influence, spurred by the mfecane, created a martial system which solidified a military tradition in Natal which remained an important component of African contribution to Natal's defence for decades to come.

With such a military tradition in the area of Natal, it is understandable the concerns expressed by "One of the People" in the Natal Mercury. If "One of the People" was not a universal example of the European attitude toward the indigenous population and their belief in the need for a new kind of military presence within the colony, he illustrates the inherent popular fear within the colony of Natal during the formative period from the 1840 s to 1870 s. This fear has been described by Shula Marks as "strong, enduring and at times almost pathological" and shows the distrust and apprehension toward a "Native uprising" within the colony. ${ }^{20}$ Most of these tensions stemmed from diplomatic relations and conflict on the Zululand border, such as the Mpande incident of 1855 alluded to earlier. But other conflicts within the colony also perpetuated strong apprehension for many occupants of the colony. The fear of the "other" from the colonists is counterbalanced by concern for the safety and stability of the indigenous population of Natal, while also expressing concern for the sizable

\footnotetext{
${ }^{20}$ Marks, Reluctant Rebellion, 144.
} 
African population in the region, numbering between 80,000 and 150,000 by 1850 and over 250,000 by $1860 .^{21}$

The fear of indigenous uprisings would be a constant concern for European colonists for most of the colony's early existence. But the colonists' response to this concern rested in a belief in the need for collective security. A collection of European volunteer military corps filled some components of this need, but many colonists refused to fully acknowledge the impact made by the indigenous military forces within the colony. ${ }^{22}$ Though present in some of Natal's news sources, the contributions made by African military units in the protection and administration of the colony are typically placed as secondary or inconsequential. Despite indigenous military presence in multiple actions carried out by the British government, there is limited emphasis on African contributions, but instead a focus on the white administrators who commanded them. Such historical narratives are largely the result of sources, as will become striking evident in the Sidoyi incident of 1857 and the Matshana incident of 1858. In others, like the Langalibalele Rebellion of 1873, it was negligence of the African units which was blamed for the deaths of the white volunteers at Bushman's Pass, with little emphasis on their role in the eventual capture of Langalibalele in rebellion. These incidents are only a small representation of not only the increased tension within military institutions of the colony, yet they also provide striking examples of African agency in the defensive institutions of Natal and its gradual transition into a colonial state during the formative period of the colony, beginning as early as the formation of Natal's colonial government in the mid-1840s.

\footnotetext{
${ }^{21}$ The African population well exceeding 100,000 by 1852, "Population”, Natal Blue Books, 1852.

${ }^{22}$ See Chapter Three: Volunteers.
} 


\section{Need for Troops: Fodo and the Klip River}

The late 1840 s were a problematic time for the colony of Natal. Not only was the colonial government attempting to establish its authority over the indigenous population, but also trying to maintain some semblance of continuity with the Afrikaner settlers within the colony. This was particularly difficult considering the very nature of the Afrikaner relationship with the British, in which the Afrikaners had fled across the continent to remove themselves from British rule only two decades earlier. They left the Cape Colony specifically because they believed the British legislation as a whole threatened the entire system of colour distinction, noting the emancipation of the slaves and the unsatisfactory monetary compensation to the slave owners, as well as other legislation. ${ }^{23}$ The Afrikaners also saw the growing African population as an invading force onto the lands that they had laid claim to as their new homeland. It remained continuingly difficult for the British to appease Afrikaner interests, especially regarding the removal of the Africans from the proposed locations being established. This tension was exacerbated around the Klip River District between 1847 and 1848.

Many Afrikaners were persuaded to stay on in the colony due to the acceptance of Roman Dutch Law by the British government in Natal, though such acceptance would be repealed by Lieutenant-Governor West in 1851 . Nonetheless, by the end of 1847 , some members of the Afrikaner community were in open revolt against British authority, fuelled by rumours of Africans acting as British sympathisers or spies in the Afrikaner republics to the north. ${ }^{24}$ To make matters worse, a group of Afrikaners along the Klip River claimed to have

\footnotetext{
${ }^{23}$ The historiography of the Great Trek is incredibly extensive, but for a fulfilling analysis of the Great Trek's impact on Southern Africa, see Norman Etherington, The Great Treks: The Transformation of Southern Africa, 1815-1854, Turning Points (Harlow, England ; New York: Longman, 2001).

${ }^{24}$ BPP: Correspondence Relative to the Establishment of the Settlement of Natal and the Recent Rebellion of the Boers, Hlangwana Before T. Shepstone, December 31, 1847: Enclosure 9 in Lieutenant-Governor West's Despatch, No. 5, February 24, 1848.
} 
achieved a treaty with Mpande, the king of the Zulu, which in essence approved the sale of a piece of land just south of the river, clearly within the jurisdiction of the colony of Natal. Reports eventually started coming into the government offices that the Afrikaners were making plans to ally themselves with the Zulu to gain sufficient control of the region. Any prospects of an alliance quickly broke down, and soon there was a clear possibility of open conflict between the Afrikaners and Zulu. The Natal government made promises to rectify the situation, but the problem was exacerbated by reported attacks from bushman across the Zululand border. This only increased the tensions between the Afrikaners and Zulu, leading to the possibility of open conflict between the two.

In response, Lieutenant-Governor West made clear to all inhabitants of the Klip River area that such territory was under British control. A proclamation was made in January of 1848, spelling out clearly that any attack against Mpande would be unacceptable and any colonial subject lending assistant or support to those attacking Mpande, would "render themselves equally guilty with the chief instigators or such proceedings". ${ }^{25}$ To give even greater weight to the proclamation, West declared that anyone who attacked the Africans under British rule would be "regarded and treated as Rebels." 26 West's actions are very telling to the changing power dynamics of the colony. Both West and Shepstone realized that the Afrikaners could not be relied upon to keep the peace within the colony, especially considering the near overwhelming hostility the Afrikaners expressed to the African population. What West did next was perhaps even more important to the changing dynamics. In his next proclamation, West warned that if such hostilities against Africans within the British territory continued, he would be forced to provide the Africans with the means of their own defence, going to far as to say:

\footnotetext{
${ }^{25}$ Proclamation by His Honor Martin West, January 4, 1848, "Executive Council Papers, Natal”, CO 181/1, 1848.

${ }^{26}$ Ibid.
} 
I shall yield to the necessity... of directing the hostility of the Natives against any portion of the white inhabitants, I shall, notwithstanding not hesitate upon the first certain intelligence that any actual attack has been made upon the said Natives, to put into their hands such a supply of fire arms and ammunition as... will, I trust, enable them to repel all such attacks. ${ }^{27}$

This statement was a direct challenge to Afrikaner authority while also illustrating the desperation of the lieutenant-governor's situation during Natal's first years of existence.

Though no formal military organization was announced, the proclamation does illustrate the willingness of the colonial government to consider using Africans as an instrumental piece of defence, even if only for the defence of other Africans.

By February 1848, Governor Smith of the Cape had provided additional land grants to the Afrikaners as an incentive to remain within the colony. ${ }^{28}$ The lack of European settlers within the colony was one of the primary reasons these measured by the British government. What the disputed of 1847 and 1848 illustrated to West and Shepstone was the necessity for a strong ally within the colony of Natal. The European population was far too small and the Afrikaners were uncooperative. ${ }^{29}$ Nevertheless, it seemed inconceivable to rely on Africans as a main pillar of support for the colony as a whole. The idea, however, was now present in the minds of the colony, and the continuing disputes along the northern region of Natal would act as the catalyst for the first use of African troops as precursor for the formation of African military institutions within Natal's system of colonial defence.

\footnotetext{
${ }^{27}$ Proclamation by His Honor Martin West, January 13, 1848, "Executive Council Papers, Natal”, CO 181/1, 1848 .

${ }^{28}$ Under the proclamation of 1848 , over 1.2 million acres were disposed, including the lands occupied by many Afrikaners, who had been excluded during the initial land distribution in 1843. Dispatch No. 38, Papers Relative to the Native Affairs in Natal, CO 879/1, 1863.

${ }^{29}$ Guy calls the use of Africans "Shepstone's dreaded alternative", but with "the Boers in the west and the Zulu in the east, it was a dangerous situation, but [Shepstone] felt that he could call on the colonial chiefs living between them." See Guy, Theophilus Shepstone and the Forging of Natal, 114-116.
} 
Problems with the Afrikaners were not enough for the establishment of any formal African military corps. Indigenous troops would have to be considered a necessity and receive the support of the both the government in Cape Town and London. Conveniently for Natal's colonial government, the opportunity presented itself in the case of "native feuds" between chiefs attempting to consolidate their power under the new British regime. In January 1847, Fodo of the Nhlangwini contested the passage of another group of Africans crossing the Mzimkhulu River, resulting in a number of deaths, multiple individuals captured, and several hundred cattle being seized. In response, Theophilus Shepstone, the recently appointed Diplomatic Agent, organized a harsh response against Fodo. ${ }^{30}$ A small contingent of 50 men under the command of Captain Blenkensopp of the $45^{\text {th }}$ Regiment was called up. This unit, however, would not be the major thrust of the force sent against Fodo. Instead, an indigenous regiment or impi was called upon to support Shepstone in the settlement of the "native feud". Shepstone reported that on finding that Fodo with his cattle had sought refuge in densely wooded ravines, sent his new contingent against the fleeing chief. Shepstone employ an African force of about 500 men to secure Fodo and his chiefs, "with strict orders to avoid bloodshed as much as possible." ${ }^{11}$ With this sizable force, Shepstone and his African troops were able to provide for the release of all captives except two, as well as the recapture of about 200 cattle. Shepstone found it necessary to seize all of the cattle belonging to Fodo, amounting to 7,000 head, and to retain them in his possession until Fodo's people, with the exception of a small number of fugitives, had signified their submission to the uncle of Fodo whom Shepstone had appointed after Fodo's deposal (though Fodo would be restored to his chieftainship by Shepstone by the end of the year). This tactic, though typical in Shepstone's

\footnotetext{
${ }^{30}$ Guy hypothesizes that Shepstone felt that a show of force against a prominent inkosi was needed in the isolated section of Natal occupied by Natal. See Ibid., 103.

${ }^{31}$ BPP: Natal- Correspondence Relative to the Establishment of the Settlement of Natal, 1848, Governor West to Governor Cape of Good Hope, February 19, 1847. Also see No. 54, Governor Sir H. Pottinger to Earl Grey No. 25 March 24, 1848, "Measures of Lieut.-Governor of Natal for preservation of peace of the district".
} 
admiration of the colony, is one of the first major instances of his use of African troops called upon as a kind of levies to implement imperial will and act as a legitimate force for colonial security. Praised for his actions by Lieutenant-Governor West, Shepstone and his African forces were presented as a key necessity for Natal's security:

Without the most prompt and energetic measures to suppress the first symptoms of an insurrectionary character, or of internal wars among the several tribes constituting the immense native population of this district, this quarter would be thrown into inextricable confusion; and I trust that the result of these measures, upon which in order to render them effective it was necessary, as I have already pointed out, to detach a strong body of infantry and the whole of our mounted forces, may tend, as far as my limited means will allow, to enforce the respect of these tribes, and thus maintain the tranquillity of the district. ${ }^{32}$

With such praise, it is somewhat surprising that by the end of the year Earl Grey, Secretary of State for War and the Colonies, had diminished any continuing preference for the reliance on African forces.

By the end of 1847, commissioners working on the formation of Natal's colonial government suggested to Earl Grey that "a large force of these [African] people, armed in the native manner, may be readily called out for a temporary purpose, and if controlled by the presence of a more regular force would render good service." 33 Earl Grey agreed that Natal's colonial government should make used of the resources and manpower available to assist in overcoming "any refractory chief", but still contended that a more disciplined force would "give confidence to the native force serving under the orders of the Colonial Government, and to secure its obedience." 34 Though such a policy was directed to the governor of the Cape, it was the implication from Earl Grey that such a force would be critical for the newly

\footnotetext{
32 Ibid.

${ }^{33}$ BPP: Natal-Correspondence Relative to the Establishment of the Settlement of Natal, 1848, No. 66 Earl Grey to Governor Sir H. Smith, No. 46 December 10, 1847.

34 Ibid.
} 
established colony in Natal. Instead of the African forces, Early Grey instead insisted on the establishment of two or three companies of pensioners along the same principles that had been adopted in New Zealand, with " 200 or 300 old soldiers so established at Pietermaritzburg would give great support to the Colonial Government, and ought not to cost [Britain] anything beyond the expense of removing them there." 35 Of course, as has been previously illustrated and will continue to be emphasized throughout this chapter, such simplistic measures were never implemented due to cost and impracticality.

The Fodo incident illustrates not only the significant necessity of African troops in the creation of Natal's defensive structures, but also how they remained the most consistent element of Natal's colonial defence. The $45^{\text {th }}$ Regiment was only stationed in Natal from 1843 to 1859 , the volunteer corps would be an inconsistent pillar of colonial defence until greater formalization after the Langalibalele Rebellion, and the police, both European and African, would be largely responsible for civil matters in the urban centres of the colony. The Fodo incident showed that Shepstone's use of African forces would remain a staple of colonial control, especially as "the action took place in a region as remote as any in the colony and demonstrated to anyone who doubted it that there was no place to hide" from Shepstone and his African troops. ${ }^{36}$ Perhaps even more importantly, this initial use of Shepstone's forces would lead to a continuing relationship with many of the African leaders in Natal, including Ngoza, one of the leaders of the Mtintandaba. (see below) Nevertheless the consistent attempts to reinterpret, reimagine, or even diminish the African's role in colonial defence, as was perpetrated by Earl Grey, would also remain a constant theme for the remainder of the formative period of the colony of Natal, and illustrate the fluid nature of decision making in regards to this critical pillar or colonial defence.

\footnotetext{
${ }^{35}$ BPP: Natal-Correspondence Relative to the Establishment of the Settlement of Natal, 1848, No. 66 Earl Grey to Governor Sir H. Smith, No. 46 December 10, 1847.

${ }^{36}$ Guy, Theophilus Shepstone and the Forging of Natal, 105.
} 
Perhaps most strikingly, only months later, Earl Grey's call this dramatic shift in the military structure of the colony was dismissed. Instead of "native cavalry" and pensioners, the members of Natal's executive council requested pause to see how the colony's newly instituted "Police" may work out, having "worked well in every respect." 37 So pleased was the lieutenant-governor with the force that he suggested increasing their number to 500, and have their pay taken from the local revenues instead of the military budget, making the African pay for their own protection supplemented by "their share on general taxes on land and cattle." ${ }^{38}$ What caused this shift and what was this militia that were so directly praised for their actions? This "Native Corps", founded in conjunction with the Natal Native Police, became illustrative of the militaristic nature of African participation on the structure of colonial defence, especially in light of possible invasion, insurrection and rebellion within the colony.

\section{An African Militia}

Theophilus Shepstone, Diplomatic Agent to the Natives and key colonial official in Natal's government, had made ample use of indigenous troops during the early period of Natal establishment during the late 1840s. Typically described as a "native corps", Theophilus and his brother John would travel across the countryside with an African contingency to enforce British authority and the removal of African squatters. ${ }^{39}$ Initial attempts at a "Natal Native Militia" were organized in the 1848 , but the parameters and equipment of the groups were somewhat ambiguous. An initial corps of 50 troops was organized in April 1848, equipped with "muskets without bayonets...their knapsack comprised a blanket, folded in a length convenient for slinging obliquely from the left

\footnotetext{
${ }^{37}$ Meeting 29: Executive Council, Natal, Pietermaritzburg, July 17, 1848, CO 181/1, 1848.

38 Ibid.

${ }^{39}$ The Natal Witness, July 14, 1848.
} 
shoulder to the right hip" or simply a "light marching costume". ${ }^{40}$ This unit typically acted as an escort force for Shepstone or even an extension of the Native Police. With the announcement by the Natal government of Theophilus Shepstone as "captain-in-chief of all the Native Forces in [the] District”, a much larger force began to be mustered. ${ }^{41}$

By September, a militia of two hundred Africans was raised and began performing drills outside of Pietermaritzburg. Unlike the initial force of fifty, these Africans were armed and equip in a far more traditional fashion. Despite their loose knee breeches "after the fashion of sepoys", the troops under Shepstone's command were equipped in a similar manner as those in the time of Shaka, particularly the traditional headdresses: one company "having a plume of black ostrich feathers; another preferring to add to their stature by a single white feather or the same bird, fixed so as to stand erect from the centre of the forehead." 42 The militias were also armed with the traditional assegai and large shields of the impis. Such units at the time were seen by some members of the Natal community, including the editors of the Natal Witness, as both a source of apprehension, and a key necessity for the security of “100,000 sable subjects."43

With such a variation in titles and descriptions, it is unclear where the "Natal Native Militia" and the "Natal Native Police" begin and end. Though these formalized units of the Natal Native Police were created under a direct proclamation from the Cape Colony during the creation of the Natal colonial government, these militia forces seem to have a more transitory characteristic than their police counterparts. It is likely that the only formalized force was created as the Natal Native Police in 1848, as was described by John Shepstone. ${ }^{44}$

\footnotetext{
40 The Natal Witness, April 21, 1848.

41 Ibid.

42 The Natal Witness, September 22, 1848.

43 Ibid.

${ }^{44}$ See Chapter Five: African Police.
} 
Even within Shepstone's own account of the founding of the Native Police, there are strong discrepancies that make it unclear what organizations are being referred to. ${ }^{45}$ Perhaps the most striking and confusing element of these newly formed African military units was the inclusion of the Mtintandaba. ${ }^{46}$ Described by John Shepstone as "a kind of Government reserve force", the Mtintandaba was formed by Theophilus Shepstone to act in response to any kind of uprising or other occurrences in the colony. The name derived from the verb ukuthinta, to touch, and the noun indaba, or affair. Hence, the Mtintandaba was intended to be a force that was "in touch with affairs" or, more appropriately, a defensive response force. ${ }^{47}$ Ngoza kaLudada, Funywayo kaMpopama, and Mqundane (also known as Jantshi) were in command of the force acting as indunas for Shepstone and all achieved great power within the indigenous hierarchy of Natal. Ngoza had fought against the Afrikaners at Blood River but had moved to Natal and allied with Shepstone during the Fodo incident. He did so well in assisting the British that he caught the attention of Shepstone, and eventually gained the position of chief induna and was appointed to a position in the Mngeni valley near Table Mountain to the east of Pietermaritzburg. ${ }^{48}$ Despite these details that were revealed later in the oral tradition, incidents involving these African units were never consistently presented in either government documents or the press. This limitation makes it considerably difficult to differentiate between "police", "corps", and "levies" in the history of early Natal, forcing historians to have a more amorphous presentation of African military organizations.

\footnotetext{
45 John Shepstone described the uniform as white canvas suits, but the James Stuart Archives notes that with the Native Police Corps being disbanded in 1851, "it is not clear to what later uniform Shepstone is referring." See Webb and Wright, The James Stuart Archive Vol. 5, 320.

${ }^{46}$ Guy equates this unit, which he denotes as the "Thintandaba", with the Natal Native Police Corps. There remain some discrepancies which exist in early descriptions of the Police Corps and this unit. Guy, Theophilus Shepstone and the Forging of Natal, 122.

${ }^{47}$ Webb and Wright, The James Stuart Archive Vol. 5, 297, 320.

${ }^{48}$ This area was home to many of Africans who had no legitimate home, and as there were many of them, allowed Ngoza to eventually become one of the most powerful chiefs in Natal. See Guy, Theophilus Shepstone and the Forging of Natal, 105; Webb and Wright, The James Stuart Archive Vol. 5, 297.
} 
Whatever the formal organization of these African corps, it is obvious that they remained an important component in the early formation of Natal's colonial security. The late 1840 s, as has been previously discussed, was a period of considerable concern and apprehension within the colony, chiefly in regards to the matter of security. Calls for some type of force were seen in the Witness during this period, emphasizing that to protect itself, the colony must establish some type of standing force with such organizations requiring "tact, time and patience", something considered lacking in the indigenous African forces being established. ${ }^{49}$ Overall, the opinion remained that it would be better to rely upon "voluntary bands of the colonists, uniting, not from any desire for war, but from the calm conviction that disturbances may arise" than "the dependence to be placed on the native agency". ${ }^{50}$ This, in light of Shepstone raising a "native corps" which is reported to be numbering less than 16,000 , predated the main thrust of the volunteer movement by half a decade, and illustrated the disdain expressed for the forces being implemented by Shepstone, despite its successes. ${ }^{51}$

The idea of a "native corps" was not considered practicable by the editors of the Witness, with concern that such a system implemented would diminish the necessity for the presence of the regular troops (despite the large cost to the colony of stationing imperial troops). Though the editors appreciated "the value of efficient defence, it is not fair to undervalue any attempt that may be made to increase the means of protection by economic plans...any new arrangement for the promotion of safety, and the prevention-rather than the overthrow of hostility,- should be hailed as an improvement both in an economic and

\footnotetext{
${ }^{49}$ The Natal Witness, September 1, 1848.

${ }^{50}$ Ibid.

51 The Witness' estimates of 16,000 Africans was presumably an exaggeration, as this number likely represented the total of able African warriors under the influence of the British government at the time, not those under the direct control of Shepstone, especially if only taken into account the forces of the Native Police Corps or even the Mtintandaba.
} 
military point of view." ${ }^{52}$ Again, the economics of the colony remained an important component. The company was considered an exception instead of a rule, despite their successes in preventing Langalibalele from being "eaten up" by Mpande, though the corps arrived long after Mpande's troops had been sent off. ${ }^{53}$ The African unit was still seen as a possible threat, even though the Witness was somewhat impressed by the corpss "light marching costume, ranging three abreast and keeping step in good order, [and beginning] to show symptoms of careful discipline." 54

The Shepstones remained committed to the idea of an African military institution in the colony, not only for the security of Natal, but also for the perceived benefit of the African. Decades after their initial formation, John Shepstone still believed that a "native regiment" should exist in Natal, claiming that "one must utilize services of Natives in connection with themselves, i.e. in regard to management of their own affairs. ${ }^{, 55}$ Despite the distance of time in the Shepstone interview, which took place in 1912, his opinions still resonated that the Africans "like having authority" and that "Responsible Government had done so much harm in removing responsibility from the chiefs...they [the chiefs] know their people and work in our interest if entrusted with the management of their affairs."

There did appear to be some measure of respect for these new military institutions that were being created from some within the colony. In May 1849, Shepstone, Lt. Howell, and "a division of the Native Corps" returned from the Klip River Division with seven prisoners,

\footnotetext{
52 The Natal Witness, April 21, 1848.

${ }^{53}$ Langalibalele had fled the Zululand in 1848 in a dispute with Mpande. His positon as a prominent chief was unitized by Shepstone until Langalibalele's own rebellion in 1873.

54 The Natal Witness, April 21, 1848.

${ }^{55}$ Webb and Wright, The James Stuart Archive Vol. 5, 294.

${ }^{56}$ John Shepstone's opinions of past events must be taken with some trepidation (especially the proximity of his death in 1916) but his overall biography does have a consistency in his opinions of the indigenous population of Natal. Ibid.
} 
two said to be charged with murder. ${ }^{57}$ The troop movement was reported to originally be related to the settlement of Africans in a new location by Shepstone. Though it appeared that the diplomatic agent was traveling with what could be inferred to be members of the Native Police, Shepstone gave the order for another regiment to be made available if necessary. When attempting to consolidate the forces in a valley, Shepstone deployed his corps on one side and once:

the malcontents were descending the opposite side of the valley, the latter were staggered at the appearance, as if by magic, of a well known clan, full armed, and attentively awaiting [Shepstone's] orders. In token of entire submission the over-awed kraals drove their cattle out to be taken possession of, and tendered their willingness to obey whatever directions might be given. ${ }^{58}$

In what was reported by the Witness with almost a passing curiousness, Shepstone thanked the African regiment "that had come so far without having been required to do anything worth the trouble" while the African captain of the regiment stated "his orders were to come and receive orders. ${ }^{" 59}$ The paper reported that farmers who were present expressed their surprise at the skill and authority Shepstone possessed, as well as the organization of the African troops and their ability to mobilize so quickly. Such a report could be dismissed as a show of Shepstone's authority over the indigenous population, but the reverence, or at least respect, that the editors of the Witness show to the African chiefs illustrate the potential benefits of the African troops within the colony. The surprise and slight admiration expressed by the farmers also showed a lack of universal scorn for the African military systems, especially when used to the benefit of British and European authority. Shepstone was the key implementer in this situation, and without the man who gave the orders, farmers could just as easily see those same forces driving them from their settlements and laying the ground to

\footnotetext{
${ }^{57}$ The Natal Witness, May 11, 1849.

${ }^{58}$ The Natal Witness, May 11, 1849.

${ }^{59}$ Ibid.
} 
waste, as had been done in the days of Shaka. It is little surprise then that these reservation would surface once again when even more Africans were called to fight for the British Empire and march through the colony of Natal.

\section{Call for Troops in the Xhosa War}

Though Natal began to attain some autonomy during the early 1850 s, it was still unable to ignore the political tension present amongst its neighbours, especially in Kaffraria. By 1850 , there was an upturn in horse thefts, the purchase of guns, assegais being constructed, and general desertion by workers amongst the Xhosa to the south of Natal. By Christmas, the Xhosa launched a coordinated rebellion in British Kaffraria and beyond, beginning the eighth Frontier War of 1850-1853 (also known as one of the many Xhosa or "Kaffir" Wars) ${ }^{60}$ Perhaps most unnerving was news that Cape Governor Harry Smith had been besieged at Fort White. Humiliatingly, Smith was forced to escape to King Williams Town by blackening his face and posing as a Cape Coloured, where he reported to the colonial office that British Kaffraria was in critical condition, due to the Xhosa who were described as a people of "determined, reckless and savage hostility" ${ }^{61}$

Such news would only exacerbate a fear amongst the colonists of Natal of an indigenous uprising that would threaten the lives of European colonists. The solution, similar to the fear that resulted from the Mpande crisis years later which spurred on the volunteer movement, was a call for greater troops within the colony. Nevertheless, there was clearly a stark contrast between what the colonist envisioned and what was proposed by the colonial government. This contrast reveals a contentious division over the perceived role of colonial troops within the colony and abroad.

\footnotetext{
${ }^{60}$ For a more comprehensive examination of the causes and results of the war, see Price, Making Empire, 233266.

${ }^{61}$ Harry Smith to Earl Grey, December 26, 1850, CO 48/309. Quoted in Ibid., 220.
} 
In January 1851, Sir Harry Smith requested that Lieutenant-Governor Pine raise an indigenous force of between one and three thousand "Zulus" to act as a force against the Xhosa fighting in the frontier war. Such a force would relieve the British being attacked in Kaffraria with a push by forces from Natal. Ironically, Harry Smith saw this rebellion not just as a challenge to British authority, but a betrayal to the "civilization" he had attempted to bring to the Xhosa who rebelled, as well as the Khoikhoi and Coloured Africans who joined the war. By the time Smith had made the request to Pine, the war had shifted to that of a race war, in which the alliance of blacks against whites was in direct contradiction to the preservation of British rule. With the attempt to raise such troops, Smith praised Pine who had "acted for the great cause, White v. Black, most opportunely \& judiciously."62 Pine, according to Guy, saw an opportunity in raising such forces, allowing him to consolidate his control of Natal's colonial government, and not necessarily to preserve the racial purity of the colonial expedition. This prospect rested on Pine's fondness for "men of action" and perhaps even his desire to associate with the hero of Aliwal, Sir Harry Smith. ${ }^{63}$

Even with Pine's enthusiasm, by March, no force had been successfully organized. Though Shepstone had succeeded in initially gaining the local chiefs approval of the plan, on January $17^{\text {th }}$ the executive council expressed their misgivings about the plan, though allowed it to continue further. In the meeting, Shepstone even went so far as to confide in the colonial secretary that he deemed the plan "not only disastrous in its consequences for this District, but actually 'suicidal' to Sir H Smith himself." 64 Shepstone, in all practicality, saw the major problems with such an expedition. The colonial government had yet to solidify its own control over its indigenous population. What hope would it have of maintain control of its

${ }^{62}$ Quoted in Elizabeth Elbourne, Blood Ground: Colonialism, Missions, and the Contest for Christianity in the Cape Colony and Britain, 1799-1853 (Montreal: McGill-Queen's University Press, 2002$), 357$.

${ }^{63}$ The simplicity of following orders was also a likely incentive. See Guy, Theophilus Shepstone and the Forging of Natal, 156.

${ }^{64}$ Colonial Secretary Moodie to Lt. Gov. Benjamin Pine, January 17, 1851, CO 179/17, No. 8811, 1851. 
people outside of the borders of the colony? To make matters worse, some of Natal's chiefs, including Matshana, who would later be expelled from the colony (See Below), did not believe they were even capable of providing the manpower that was being requested, informing Shepstone that their people (assumedly those Africans already allied with Shepstone) "did not know how to fight, they were women, they left the Zulu country because they feared firearms, and they would also not be where they were if they were not women."65 Such a lack in confidence, though not decisive, caused Shepstone to review the proposal and made his suggestions for a reconsideration of the plan.

Not to be dissuaded, Pine looked to other individuals to lead his African levies, and eventually settle upon Henry Francis Fynn. Fynn's role as a military presence in the colony cannot be overstated. He was amongst the first Europeans to meet the Zulu king Shaka, and remained one of the most famous residents in the region. Over the ensuing years, however, he had achieved some semblance of autonomy and even made use of the Africans he influenced in a military capacity, commanding a private military force of Africans since the 1820 s. His "African Force" which appeared in all purposes to be under his direct control, had a measurable impact on the security and military presence of Natal, within and outside its borders. One such incident revolved around the stealing of cattle from the across the border, resulting in a striking challenge to the authority of the local Mpondo leader, Faku. After Fynn had been appointed colonial resident with Faku in 1848, tensions had risen in the ensuing period over continuing disputes and encroachments with African chiefs. Fynn, however, was not entirely representative of the use of colonial force during this period, but instead was principally a rogue figure that attained near autonomy in the southern reached of Natal

${ }^{65}$ Quoted in Guy, Theophilus Shepstone and the Forging of Natal, 157. 
following his initial settlement in the $1820 \mathrm{~s} .{ }^{66}$ To Pine, Fynn represented an alternative to Shepstone that would allow for the raising of the levies required and retain the ability to control such a force as it marched into Kaffraria. Ironically, Fynn would use such forces to consolidate his own power base against Faku. The levies that were raised in 1851, though disbanded within the year, remained an intimidating group to Faku, who assembled his own force in response during mid-April of 1851.

Despite the attempts to retain some sense of secrecy with Pine's arrangements with Fynn, the plan to raise these African levies was soon revealed to the colonists of Natal. Unsurprisingly, there was a negative reaction amongst many colonists. Thomas Phipson, future sheriff of the colony, was one of the more outspoken critics of the rumoured policy of raising indigenous levies for the defence of the colony. To most colonists, the majority of African troops within Natal were placed in defence of their own individual kraals, and were used to a limited extent in internal matters. Though the Native Police had been a presence within the colony, few Europeans possessed an overwhelming fear of such a small group. Greater apprehension existed with the idea of a large African levy or militia which could overwhelm the colonists and lead to their ultimate removal from the colony. Phipson, in his initial quarrel against the African levies being mustered by Pine, argued that the creation of these units was not only immoral, but illegal because such actions lacked approval by the colonial population and was being implemented solely by Lieutenant-Governor Pine without the approval of the legislative or executive council. Phipson's initial suggestion, which took the form of a letter to the government, was more of a criticism of the overall system of

\footnotetext{
${ }^{66}$ Even the group under Fynn's control along the Mzimkulu River was rumoured to be composed of some of his own decedents with numerous African wives. Stapleton, Faku, 158.
} 
defence within the colony, leading to his suggestion for reliance on white volunteers from within the colony for defence, stating that "a volunteer is worth two pressed men."

A more direct outcry against the proposed levies was expressed a few weeks later in a memorial to the Secretary of the Colonies, Earl Grey, which was published in the Natal Witness, written by Phipson and accompanied (according to the Natal Independent) by 100 signatures. The memorial was propagated by the information that Pine had sidestepped Shepstone's authority on the matter and instead directly contacted Fynn about the creation of the African levies. The information had come from James Allison, a Wesleyan missionary, who informed Phipson that Pine had ordered Fynn: "to muster and call to arms certain native British subjects residing within this District [Natal]; and further that the said Fynn had, while so residing out of the boundaries of this District, sent orders or messages to certain Native Chiefs and others within the said boundaries, to muster and assemble in arms." 68 Such actions were reportedly done without the knowledge of Shepstone, though Pine did announce in the Witness that letters had been exchanged between he and Shepstone, but countered that "if the news of such disclosures as these reached Downing-street, all the Government officers here would be instantly dismissed." 69 The memorialists emphasized once again the simple fact that Fynn did not reside in the colony, and should therefore not be an active agent in any such affairs. Fynn's authority over the African population was called into question, rightly so considering Fynn primary use of the levies against Faku as a means to maintain his own authority in the region instead of pushing deeper into Kaffraria as requested by Harry Smith.

The "clandestine, unconstitutional, and illegal proceedings" enacted by Pine were seen by the memorialists as an affront to the colonists "rights and liberties as British

\footnotetext{
${ }^{67}$ See Chapter Three: Volunteers and Currey, Letters and Other Writings of a Natal Sheriff: Thomas Phipson, 1815-1876, 32.

68 “The Memorial of Thomas Phipson," The Natal Witness, March 17, 1851.

69 Ibid.
} 
subjects." 70 The memorial, however, was an attack on the authority of Pine and the manner in which he overstepped his powers in calling up the African levies. Yet Phipson and his supporters made clear that such an armed force of Africans "destitute of any proper and efficient control" would "endanger the peace of the District." indigenous troops was obvious in such accounts, and the possibility of African troops sent out to the frontier on their own for the defence of the colony was seen as simply unsound, but also inhumane, indicative of a mixed view of paternalism and contempt for indigenous defensive forces. Like so many accounts of the African troops within the colony of Natal, the African is quickly brushed aside in the debates over importance of colonial authority. The primary concern for the memorialists, though using the African troops as a conduit, is the abuse of power by Pine. After the initial accusations, it was merely the African's role in the debate which had any major importance, and not their role in the colony's defence. Instead, like so many debates involving Natal's African troops, the African is cleared aside for concerns about the Europeans role in colonial government, and the actions of their leaders that are seen as a "great detriment of the trade, commerce, agriculture, peace security, and well being of the white population of this District." 72

Perhaps most surprising, when the issue of the African forces was more directly addressed by the colonial population, much of their concerns rested on mere rumour and supposition, and not on any true awareness of the situation. C. Preller, a field cornet in Natal, addressed a letter to the secretary of the governor of Natal in response to the news that Shepstone would raise a "native levy" of 6,000. Preller claimed to have knowledge from a Mr. Potgieter and others of a plan by the Africans within the proposed force to mutiny once they had proceeded as far as the Mkhomazi River, some 40 kilometres south of Durban, kill

\footnotetext{
70 Ibid.

71 Ibid.

${ }^{72}$ Author's emphasis. The Natal Witness, March 17, 1851.
} 
Shepstone and his officers, and return to Natal to attack the settlements. Preller called attention to the "fact that the Native Police, who were intended to be in some measure a shield against the Bushmen, have been deliberately withdrawn from their station at the Spioen Kop, leaving the pathway of those predators entirely open."73 Preller neglected to consider that if such a mutiny occurred, this pathway would be unnecessary as the mutinous troops could simply turn back and return the way they came instead of marching to the north and enter the colony via Spioen Kop.

With such controversy and debate, it is no surprise that the African levies never materialized. By April, a force of 3,000 gathered along the south coast, but despite all attempts by Shepstone and Pine to encourage the troops deeper into British Kaffraria, there was little movement. In May, the expedition was called off by Harry Smith. The failure of the column was multifaceted. Fynn, though famous for his dealings with the indigenous population of the region, did not have the same personal relationship with the major African players that Shepstone possessed. Fynn's reputation by 1851 was also becoming over exaggerated and led to his eventual dismissal as magistrate of Faku's people and the abolition of the position the following year. Even with multiple attempts by Pine and Shepstone, there was a lack of overall organization and preparation for such a force. This was not helped by the continual changing of minds and alterations of plans that characterized this six month period in 1851 .

Admittedly, Harry Smith did not anticipate the simple problems of ethnic and social divisions that characterized Natal. Moreover, this incident contributed to the eventual distancing and open hostility between Pine and Shepstone that would characterized the

73 “Letter from Mr. C. Preller, Field Cornet to Sec. of Gov. Natal”, The Natal Witness, March 21, 1851. 
remainder of Pine's first tenure in Natal. ${ }^{74}$ What remains most striking, however, about this debate and the failure to raise the indigenous levies was the apprehension, paranoia, and outright rumours that dominated the colony during this period. Despite having both African military and police institutions within the colony for almost three years, colonists still retained major anxiety about African troops defending their homes and livelihoods. The white colonists' reservations on the use of African troops to defend Natal was, in context, nearly unfounded, as the majority of colonists did have experience with African troops within Natal beyond those commanded by Shepstone, and were in fact indebted to such groups for much of their safety during the early years of the colony.

\section{The Cape Mounted Rifles}

Other than the $45^{\text {th }}$ Regiment of Foot stationed at Fort Napier outside Pietermaritzburg, the largest and most continuous military presence within the colony during its first decade of existence was the Cape Mounted Rifles (or CMR), a cavalry unit that acted as the main protectors of the frontier region of the colony, from the border of southern Natal to the Drakensberg Mountains. The Cape Mounted Rifles remained in existence from 1806 to 1920, but their role in this formative period is illustrative of the role of African forces within the colony of Natal. In 1850, of the 12 troops in the CMR, eight were composed of Europeans who were formerly members of the British Army. Four were composed of coloured men from the Cape. These units, however, were typically referred to as "Hottentots", though there association with the Khoikhoi is somewhat ambiguous. ${ }^{75}$ These units also acted partially as

\footnotetext{
${ }^{74}$ The major point of contention rested on the use of amalgamation to destroy the locations system. Earl Grey had told Pine that "much blame for these unfortunate differences must rest upon yourself \& Mr. Shepstone". The tension between these two individuals rested almost solely on perceived interpretation of the best course of action for the future of the colony. See Guy, Theophilus Shepstone and the Forging of Natal, 161-163.

75 According to Young, this is "curious error" which appears in many books by various historians, but "the word 'Hottentot' was in those days loosely used when referred to Coloured folk, by which we mean people of missed white and other blood." See P.J. Young, Boot and Saddle: A Narrative Record of the Cape Regiment, the British Cape Mounted Rifles, the Frontier Armed Mounted Police, and the Colonial Cape Mounted Riflemen (Cape Town: Maskew Miller Limited, 1955), 62.
} 
the police force for the colony during its formative period, being sent out to capture criminals who attempted to escape into the frontier. Policing, even on a small scale, was centred on the rural areas, especially the theft of cattle while "adequate police attention was given to every case."76

Apprehension toward the CMR from the colonial troops probable increased following their participation in a mutiny near the Bushman's River during the Frontier War of 1851.

The outbreak of the Xhosa rebellion in 1851 astonished the British authority in the region, but even more shocking was the desertion of almost half of the Cape Mounted Rifles, who took their arms and military experience to join the Xhosa rebels. ${ }^{77}$ Ironically, one of the major leaders of the Xhosa guerrilla forces on horseback was Willem Uithalder, a pensioner from the Coloured ranks of the CMR. ${ }^{78}$ There is no evidence that troops stationed in Natal were part of this group of deserters, but it would have remained part of the colonists' collective conscious involving African troops. ${ }^{79}$ Such actions would lead to the eventual "whitening" of the regiment with the gradual reduction of African members in the ranks during the $1850 \mathrm{~s}$ and $1860 \mathrm{~s} .{ }^{80}$ The CMR would, however, continue to patrol the Natal frontier well into the 1870s but by this time the Natal government had established its own mounted police force for the protection of the colony.$^{81}$ The CMR, along with the British troops stationed at Ft. Napier,

\footnotetext{
${ }^{76}$ Young rightly points to the amorphous nature of such a force: "In a country such as South Africa where war, one may say, had been endemic, the mounted policeman had necessarily to be a soldier too." Ibid., 79.

${ }^{77}$ Price, Making Empire, 221.

${ }^{78}$ Uithalder would have a lasting legacy amongst the Coloured community in the Kat River community, even acting as the descendent of the fictional character Piet Uithalder in an early $20^{\text {th }}$ century newspaper supporting the African People's Organisation (APO). Mohamed Adhikari, Not White Enough, Not Black Enough: Racial Identity in the South African Coloured Community (Athens, Ohio: Ohio University Press, 2009), 164.

79 The larger participation of the CMR in the rebellion has also been dismissed by historians like Young. The only mention of African dissension during the Xhosa War of 1852 is in the appendices with no mention of other CMR members joining Uithalder alluded to or even considered. See Young, Boot and Saddle, 174.

${ }^{80}$ Dominy, "The Imperial Garrison in Natal with Special Reference to Fort Napier 1843-1914: Its Social, Cultural and Economic Impact," 127-128.

${ }^{81}$ For a detailed account of the movements and activities of the CMR during the 1870s and their interaction with the indigenous population of Natal, see Thomas J Lucas, Camp Life and Sport in South Africa, Experiences of Kaffir Warfare with the Cape Mounted Rifles (London: Chapman and Hall, 1878).
} 
remained a final line of defence in the case of emergencies. In extreme cases, the CMR would join other African troops as support, as was the case of the incident involving Sidoyi in the late $1850 \mathrm{~s} .^{82}$ The memory of the mutiny would remain in the minds of the colonists with Natal. The Xhosa War represented the imposing threat of black unity that moved beyond political and ethnic alliances, and represented a united Xhosa-Khoi alliance against white rule in Southern Africa ${ }^{83}$ Such perception of a widespread black rebellion contributed to the near overwhelming concern for African troops turning against their officers when moving beyond the borders of the colony. Nevertheless corruption and betrayal was not limited by race or position in Natal, but instead individual in character. This was the case with Ringler Thompson, Captain and Paymaster of the Natal Zulu Contingent.

\section{Regina v. Ringler Thompson}

The Shepstones were not solely responsible for the formation and organization of the African troops within the colony of Natal during its formative period. Local resident magistrates were also partially responsible for their own African police as well as the organization of indigenous levies in times of need. Though this provided considerable power and authority for the local magistrates, for much of the first decade of Natal's existence, many of these tasks fell to Shepstone. Pine, however, on his appointment as lieutenantgovernor, began selecting new magistrates he deemed fit and able, as he had done with Francis Fynn in the attempt to organize an African contingent in aid of forces in the Xhosa War. Pine established such alliances with men he saw as potential supporters to his agenda, whether to the contrary of other members of the colonial government, including Shepstone. John George Ringler Thompson was such a man.

\footnotetext{
${ }^{82}$ Guy refers to the Cape Corps, along with the British military, as a key element of defence, but "more as a static presence than an active force." See Guy, Theophilus Shepstone and the Forging of Natal, 121.

${ }^{83}$ See Elizabeth Elbourne, Blood Ground: Colonialism, Missions, and the Contest for Christianity in the Cape Colony and Britain, 1799-1853 (Montreal: McGill-Queen's University Press, 2002).
} 
Selected as magistrate of the Mzinyathi Location, north of Greytown along the Zululand border, Thompson appeared an ideal candidate for the position; a scholar and linguist with published works on geology, with occasional bouts of drunkenness. ${ }^{84}$

Thompson, despite his academic credentials, was not the ideal citizen. While sailing to Natal on the Washington, Thompson's life was threatened by Hughbert Baker, an Irish land surveyor also traveling to Natal. The source of the altercation was Mrs. Baker, who was reported to have been involved with Thompson (and several other passengers) in an unacceptable fashion. Thompson could be cast as the victim in this situation, but it has been speculated that Thompson was paying particular attention to Mrs. Baker primarily to infuriate her husband. ${ }^{85}$ Thompson's attitude did not seem to improve with his appointment as magistrate. Theophilus Shepstone reported rumours that Thompson had been drinking and "keeping native women" during his time as magistrate, a claim with no strong evidence and was unequivocally denied ${ }^{86}$ Though supported strongly by Pine, a pattern of behaviour can be traced which predicted Thompson's problematic tenure in Natal.

\section{During Pine's attempt to raise an African contingent to assist the Cape Colony in}

1851, Thompson had been appointed captain and paymaster of the Natal Zulu Contingent.

Though composed primarily of Africans from the Drakensberg, like most of the levies raised in 1851, the unit never achieved the size and organization envisioned by Pine and Shepstone. ${ }^{87}$ Thompson's responsibilities as paymaster allowed him access to government funds which were very limited within the colony during its early formation. The temptation

\footnotetext{
${ }^{84}$ Guy consistently describes Thompson as one of Pine's "gentlemen and scholars" that were appointed in 1851 who failed miserably in their tasks as magistrate. Guy, Theophilus Shepstone and the Forging of Natal, 170.

${ }^{85}$ Baker's consistent beating of his wife, who was described as a "very pretty interesting little wife", should not be dismissed from this account, but it does shine some light on the character of Thompson. Shelagh O'Byrne Spencer, British Settlers in Natal 1824-1857: A Biographical Register : Gadney-Guy (Pietermaritzburg: University of Natal Press, 2001), 10.

${ }^{86}$ Guy, Theophilus Shepstone and the Forging of Natal, 170.

${ }^{87}$ Not only was the name of "Natal Zulu Contingent" a fallacy, the entire endeavor was really nothing more than a false start, with no clear organization or agreement between Shepstone and Pine. See Guy, Ibid., 155-158.
} 
must have been too much for Thompson, who was experiencing considerable pressure from Pine and Shepstone to extend British authority into the Orange River Sovereignty in late 1851. It was this excursion which provided Thompson the means to move from dereliction of duty to outright criminal behaviour.

Between September 1851 and April 1852, Thompson had collected nearly $£ 1,400$ for the payment and provision of his troops in the Natal Zulu Contingent. It was revealed, however, in January 1853 that these large sums of money had been unaccounted for from the commandant's office at Fort Napier. The commandant's office had initial suspicions as early as November of 1852, but by the following January, the commandant was no longer in doubt that Thompson had "misapplied a considerable sum of Public Money" ${ }^{88}$ More importantly, Thompson had disappeared from the district for the past four or five month, and had failed to report any account of this absence. Ironically, it was Langalibalele (the leader of the 1873 rebellion) who reported in June to the hut-tax collector that he and his men had not received payment for their services to the colonial government. ${ }^{89}$ A warrant for Thompson's arrest was issued and by October, Thompson was charged before the resident magistrate of Pietermaritzburg of "fraudulent appropriation and embezzlement of a large sum of money entrusted to his charge". ${ }^{90}$

According to the initial proceedings, Thompson had collected the funds to pay for the members of the contingent over the last previous two years, but had never fully paid any Africans under his command. The promised pay for the Africans under Thompson's command was six pence a day, but for many Africans they had only received blankets and tobacco during the Orange River excursion in late 1851 . Thompson then drew nearly $£ 500$ in

\footnotetext{
${ }^{88}$ Commandant of Natal to the Honorable Crown Prosecutor, Pietermaritzburg, January 7, 1853, AGO I/8/2, $1 \mathrm{~A} / 1853$.

${ }^{89}$ Guy, Theophilus Shepstone and the Forging of Natal, 206.

${ }^{90}$ Regina v. J.G. Ringler Thompson, October 14, 1853, AGO I/8/2, 50A/1854.
} 
January 1852 and an additional $£ 600$ the following April, none of which went to the African troops. Oddly, around this time, Thompson disappeared from the colony, only to be found in late 1853 beyond the Swazi kingdom. It was this time beyond the Swazi kingdom that presumably contributed to his decline in health. Thompson was returned to Durban in September, just in time for the beginning of the formal investigation against him. By February 1854, preliminary interviews had been completed with the former members of the contingent, and the trial would commence by the end of the month. ${ }^{91}$ With Thompson's declining health, his fitness to stand trial was called into question by his defence attorney. Dr. Warring Cunningham examined Thompson in June the following year and provided evidence to the district court that Thompson had gone insane and was deemed unfit for trial. ${ }^{92}$ By this point, Thompson was no longer a viable administrator for the colony, and was shipped back to England with the support of his friends and relatives. Though the whereabouts of the money were unknown, it was reported by one of Thompson's ex-lieutenants shortly before his disappearance that Thompson was seen riding toward the Klip River Distinct to make payments, loaded with gold and too drunk to properly load his pistols. ${ }^{93}$ A simple explanation may have been that Thompson simply lost the money, or forgot that he had not paid his troops their proper dues, because of a combination of his drunkenness and mental instability. ${ }^{94}$

We can easily consider Thompson's actions to be that of a disturbed individual who became overwhelmed or simply incapable of dealing with his responsibilities in the colonial setting. Yet the manner in which he abused his power is perhaps more important to

\footnotetext{
91 The Queen v. J.G. Ringler Thompson, February 16, 1854, AGO I/8/3, 145A/1854.

92 William Sargeant to the Honorable Acting Crown Posecuotr, Natal, June 22, 1854, AGO I/8/3, 114A/1854.

93 Guy, Theophilus Shepstone and the Forging of Natal, 205.

94 Though somewhat supported by the evidence, this conclusion is complete conjecture. It will likely never be known what happened to the money, or what caused Thompson's departure from the colony.
} 
understanding the changing role of the African in Natal's defensive structure. ${ }^{95}$ The Natal Zulu Contingent, as it was known, while deemed largely a failure in its initial implementation, became a model for magisterial and eventually colonial control of the African military institutions.

It is no coincidence that the model would become prominent in not only Shepstone's administration of the colony for the following decade, but also act as the precursor for the Natal Native Contingent during the Anglo-Zulu War. Despite the failures, the money Thompson was able to embezzle illustrates that the contingent was viewed as a viable expense as more and more money was being drained from the colonial treasury. The simple fact that it took nearly two years for the crime to be realized tells volumes about the belief in the system, as well as the colony's propensity to ignore the complaints of their African subjects, especially regarding the issue of pay.

\section{Removal and Shifts in Policy}

Despite all these contentious problems, the Thompson case illustrates the importance of the indigenous military organizations, especially the African troops commanded by the Shepstones, in the formation of colonial Natal. The 1850 s were a transformative period for the colony, not only in establishing a colonial charter in 1856 , the formation of the volunteer corps, or the corporate independence of the major urban centres, but in the way in which Africans were an intrinsic part of the security and organization of the colony. At the centre of this shift was Shepstone, who continued to define the African military policy despite the

\footnotetext{
${ }^{95}$ Guy casts Thompson as prime example of Pine's failure to properly manage the men he placed his faith in, also giving greater focus to the "psychotic tendencies" that Thompson and the other "Demonical men" propagated as magistrates during this period. See Guy, Theophilus Shepstone and the Forging of Natal, 205207.
} 
intervention of detractors like Pine. One such example was Shepstone’s “Grand Removal Scheme", ${ }^{96}$

Shepstone's removal scheme was a dramatic shift from his previous administration within Natal. The plan was simple. Shepstone would lead a large body of the African population of Natal from the locations to the vast territory to the south of the Umzimkulu River, south of Natal. There Shepstone would establish a near independent African territory that would be ruled, regulated, and maintained in the traditional manner. What was most unusual about this plan was the role of Shepstone himself. Shepstone would act as supreme Chief, or Ukumkani, of the Africans in the region and direct them in the same manner any other chief would preside. The plan rested almost exclusively on Faku's cooperation, which was no difficultly considering Shepstone's relationship with the old inkosi. Shepstone had known this man since childhood, and had developed such a close relationship that the chief often referred to Shepstone as "his son.",97

The new territory created by Shepstone would not only provide a home for thousands of Africans, but would also create a "kind of safety-valve provided for the passions of the people, in case of any discontent arising among them." 98 Bishop John Colenso, who accompanied Shepstone on one of his preliminary trips to Faku's territory, envisioned, like many others, with the removal of so many Africans from the colony, those Africans left behind and those who would continue to migrate to Natal could be placed under more

\footnotetext{
${ }^{96}$ For one of the most complete examinations of the removal scheme, including its causes and organizations, see Thomas McClendon, "The Man Who Would Be Inkosi: Civilising Missions in Shepstone's Early Career," Journal of Southern African Studies 30, no. 2 (June 1, 2004): 339-58. The origins of the scheme range from frustrations win Pine to the prospect of mineral rights within the colony. If the scheme had succeeded, McClendon rightly observes: "Shepstone's role in colonial history might have been closer to that of such literary figures as the heroes of Conrad's Lord Jim or Kipling's The Man Who Would be King than to the stern-faced administrator suggested by familiar portraits-both photographical and historical-of Natal's master of African affairs."

${ }^{97}$ John William Colenso, Ten Weeks in Natal: A Journal of a First Tour of Visitation Among the Colonists and Zulu Kafirs of Natal (London: Macmillan \& Company, 1855), 148.

${ }^{98}$ Ibid., 148.
} 
"civilized" restriction, including the ending of polygamy, the use of respectable clothing, and the ending of the sales of wives, which Colenso claimed as "absolutely necessary for their improvement in civilization. ${ }^{\circ 99}$ Colenso also believed this system would greatly assist in the process of conversion by the missionaries of the colony.

Colenso's vision for the future did not stop there. Colenso believed that if Shepstone were to survive the migration with the Africans, his influence within South Africa would spread considerably. Shepstone would most likely bring Faku's people under his rule once the old chief died, and in doing so:

[Shepstone's] authority would be felt over the whole of Kafirland; and at length that very rich and productive region- incomparably the finest in all South Africa- would have rest from its many troubles, and welcome the peaceful steps of commerce, civilization, and Christianity. ${ }^{100}$

If Shepstone did not survive the migration, though, Colenso still believed it would benefit the region and not be a source of increased trouble in the colony. Despite such optimistic views and the initial approval by Pine, the plan was eventually scrapped by Earl Grey, leading Shepstone to seek other alternatives to the issue of indigenous Africans in the colony. But the removal scheme was representative of an idealized state which Shepstone could manipulate and even outright control. His previous use of African's in the Fodo incident and the Klip River increased his confidence. Though an African state manned solely by Africans was too extreme, the more direct deployment of African troops was not.

One extreme benefit, and perhaps hindrance, to Shepstone's relationship with Faku was the old chief's ability to assist Shepstone in the southern region of the colony. In one

\footnotetext{
${ }^{99}$ Colenso, Ten Weeks in Natal, 149.

${ }^{100}$ It must, of course, be taken into account that Colenso was not only a friend of Shepstone, but also Bishop of Natal and head of most of the missionary activity within the colony. Ibid., 150-151.
} 
such case, Faku requested Shepstone's assistance in reparations for cattle theft from Mdushane of the Bhaca. Making use of Henry Francis Fynn, who had become magistrate of the Mkhomazi division after his dismissal from Faku's territory in 1852, Shepstone led a force of indigenous troops in 1854 as tactical manoeuvre to cut off routes of escape for Mdushane. Another group of white volunteers were also involved, and provided the main thrust of military force from Natal, though the threat of attack from Faku was enough to have Mdushane quickly relent to Faku's demands for compensation. ${ }^{101}$ Whereas African troops had a relatively minor role in the overall conflict, it anticipated a much more striking use of indigenous forces in a series of incidents in 1857 and 1858 that, though condemned by some colonists, was illustrative of Shepstone's new policy in the use of African troops for the solidification of colonial security.

\section{Sidoyi Incident}

Like the Mdushane incident, the majority of disputes between indigenous chiefs eventually led to intervention by either the local magistrate or Shepstone. On such occasions, Shepstone would make use of the African troops at his disposal to intimidate and in some cases drive out "insubordinate chiefs". One such incident occurred in 1857 with the inkosi of the Nhlangwini, Sidoyi kaBaleni. ${ }^{102}$ Sidoyi, according to Shepstone, had been instilled as chief only seven years before, with "special pains" taken to explain to the new inkosi that his position was tenuous, "that neither the tribe nor the country were his, that he was but deputed by the Government to take charge of a section of its subjects, and that should he ever lose sight of this fact calamity would certainly fall upon both." ${ }^{103}$ There is no indication that

\footnotetext{
${ }^{101}$ For a more details account of the incident, including Shepstone's use of the image of Faku, see Guy, Theophilus Shepstone and the Forging of Natal, 217-222; Stapleton, Faku.

${ }^{102}$ Referred to by Guy as an "Inkosi of collateral lineage", Sidoyi is referenced as Usidoi in the colonial records. Guy, Theophilus Shepstone and the Forging of Natal, 538.

103 "Report of Secretary for Native Affairs Respecting the Commando Against the Native Chief Usidoi, May 27, 1857”, Legislative Council, Natal, No. 30, 1857. NCP 4/1/1/1, 1857.
} 
Sidoyi caused any major problems over the ensuing seven years, though a magistrate was eventually appointed to oversee Sidoyi and his actions were presented as "a source of anxiety amongst the old men of his tribe." 104 The source of this anxiety was Sidoyi's associating with an umthakathi, or one who practices witchcraft, a strong antecedent to the civilizing missions of the British. Witchcraft and the death penalty remained controversial topics the British were unable to property address. Many believed that the practices should be made illegal outright, as they in no way could be affiliated with civilized society. Shepstone disagreed with this approach, believing that these "savage" customs would eventually dissipate with in the locations. Still, it illustrated that Sidoyi was attempting to challenge British authority or at least expressed some resistance to colonial rule.

The catalyst for Sidoyi's challenge to colonial rule and the implementation of African troops against other Africans occurred in March 1857. During a wedding between a man of Sidoyi's people and a woman of Mshukangubo, inkosi of the Memela, only 10 miles downstream of Sidoyi, a dispute broke out between persons from both groups, resulting in one of Mshukangubo's men being killed and two of Sidoyi's being wounded. Sidoyi's people led an attack the next day against Mshukangubo's people, who retreated, leaving Sidoyi’s people to plunder the huts. The incident was immediately reported by both chiefs to the local magistrate, Mr. A.C. Hawkins, who sent messengers to stay any further violence while an investigation was organized. Sidoyi, however, was not present for this initial attack. He instead organized a larger expedition against his weaker neighbour before Hawkins could respond. Three days after the initial incident Sidoyi attacked Mshukangubo people with a force of 500 men. Mshukangubo was only able to muster 80, but, refusing to submit or surrender, was killed with 20 of his men. According to Shepstone, the next morning Mshukangubo body was discovered by Sidoyi, who proceed "with great ceremony to cut off

${ }^{104}$ Ibid. 
his right eyebrow and right hand and to extract his tongue and right eye." ${ }^{105}$ Following this incident, Sidoyi and the surviving members of Mshukangubo people were summoned by the magistrate to answer for the crime. ${ }^{106}$

Sidoyi's actions were part of a ceremonial custom which involved the transferring of power, both diplomatic and militarily, from one chief to another. Yet the mutilation of Mshukangubo was also a more concerning statement on colonial rule. These deeds by Sidoyi were not just an act of "barbarism", but a "proclamation of independence" causing Shepstone to become greatly concerned by how such an exercise in power would influence the other chiefs of the colony. ${ }^{107}$ Sidoyi's actions were not perceived simply as an isolated incident amongst minor chiefs within the colony, but instead a threat to the colonial system established by the British. Sidoyi had taking part in the one exercise of power that was strictly limited by the colonial government: the levying of war on one's neighbours. Because the act of mutilation was typically performed by independent and hereditary chiefs, Sidoyi was in essence declaring "independence" from the British authority, at least in the eyes of Shepstone. If such actions were allowed to continue, Shepstone concluded that "minor tribes would be destroyed by the more powerful, and the struggle for supremacy between the latter and the Government [would] soon follow."108 This was the source of great anxiety for Shepstone, not just for the security of the colonial government, but for the smaller indigenous groups within Natal that had fled under similar circumstances during the mfecane.

\footnotetext{
105 Ibid.

${ }^{106}$ Robert James Mann, The Colony of Natal: An Account of the Characteristics and Capabilities of This British Dependency (London: Jarrold and Sons, 1859), 219.

${ }^{107}$ I am indebted to Jeff Guy for making this connection, illustrating the deeper socio-political importance of these actions that could be easily dismissed as a component of "tribal warfare". Guy, Theophilus Shepstone and the Forging of Natal, 254.

108 "Report of Secretary for Native Affairs Respecting the Commando Against the Native Chief Usidoi, May 27, 1857”, Legislative Council, Natal, No. 30, 1857. NCP 4/1/1/1, 1857.
} 
To make matters worse, when summoned by Hawkins, Sidoyi refused to present himself along with his people, sending his excuses by a messenger. With this refusal, Lieutenant-Governor John Scott (appointed November 1856), issued a proclamation for the capture of Sidoyi in April 1857. Shepstone was instructed to summon 800 Africans to accompany a small force of Cape Mounted Rifles into the district. The orders were to arrest Sidoyi, if possible, "seize all the cattle belonging to the tribe of [Sidoyi]", take measures for the removal of Sidoyi and his family's authority, and place another person "to take charge of such portion of his tribe as may remain within the Colony."109

Some 800 indigenous forces were musters and formed into two columns. Led by Shepstone and his brother John, this force moved into Sidoyi's territory with the intention of removing the chief and replacing him. ${ }^{110}$ It should be noted that while there was a small contingent of Cape Mounted Rifles and regular troops from the $45^{\text {th }}$, the overwhelming majority of men sent against Sidoyi were Africans from the Pietermaritzburg region, presumably including the Mtintandaba. The African troops' orders were simple: they were to seize all cattle, horses and guns, and take Sidoyi and all of his principle men prisoners. Shepstone made clear that "no huts were to be burnt, nor any hard done to women and children, and no assegai to be used except in overcoming armed resistance to the execution of these orders." 111 This was an act of punishment, not warfare, in the minds of Shepstone and the colonial government. Within three days, the force had arrived in the district, and quickly seized a large number of cattle and goats, as well as a few horses and muskets. Sidoyi, however, remained elusive.

\footnotetext{
109 "Memorandum of Instructions from the Lieutenant-Governor Respecting Proceedings Against the Native Chief Usidoi, April 13, 1875," Legislative Council, Natal, No. 47, 1857. NCP 4/1/1/1, 1857.

${ }^{110}$ For another analysis of this event, see McClendon, White Chief, Black Lords, 67-68.

111 “Shepstone Report," Legislative Council, Natal, No. 47, 1857, NCP 4/1/1/1, 1857.
} 
By April $25^{\text {th }}$, Shepstone had given notice to the Africans driven away that they could return to their kraals and would be protected from any future incursions. Four days later, Shepstone succeeded in making arrangements for a general meeting with the elders of the area. At this meeting, Shepstone made clear the crimes that had been committed, and inquired to the location of Sidoyi. He was informed that Sidoyi had fled across the Drakensberg to this uncle's, who resided on the Orange River. Shepstone was quick to inform the elders that Sidoyi and his family were no longer the legitimate chiefs, and in place of Sidoyi, Shepstone placed Zashuke, one of Shepstone's induna lieutenants, in command of the area. But a new leader was only the beginning of the punishment inflicted by Shepstone and his African troops. The elders agreed to Shepstone's appointment, and in return only asked that "the Government would look upon them with a friendly eye, and grant them 'a spark to kindle a fresh fire' - a figurative expression to mean a few cattle to begin the world again with."112 This was ostensibly because Shepstone and his troops had seized 7,000 cattle, 12 horses, seven stands of firearms, and a large quantity of goats. Of this quantity, only 1,600 were restored to the Africans, 1,200 left in control of the magistrate for future disputes, 3,000 sold at public auction, and 700 cattle presented as payment to the indigenous forces that aided in the campaign, a continuation of the traditional African practice of using cattle as currency. ${ }^{113}$ All told, only ten percent of Sidoyi peoples' cattle escaped seizure, representing a massive impact on the economic viability of the district. Though the casualties of this incident were low, with only four of Sidoyi's people and one of Shepstone's being killed, the latter by accident and not direct conflict, the loss of cattle would have severely hampered the region's economic viability for years to come. Shepstone believed this punishment to be justified, and even touted the acceptance of such action by Sidoyi's people. Shepstone spent the final two weeks of the expedition without his troops in the Mkhomazi district, "surrounded by large

\footnotetext{
112 Ibid.

${ }^{113}$ Ibid. and McClendon, White Chief, Black Lords, 680; Mann, The Colony of Natal, 220.
} 
numbers of the very people I had been engaged in punishing." The secretary of native affairs expressed no apprehension and experienced no resentment from the Africans, claiming "their hope for the future was in the Government, because although a child may be punished, he still remains a child; and because when a parent punishes he leaves the shell."114

Because of the severity of these actions and their detrimental impact on the Africans in the district, the activities of Shepstone and the British government were condemned by some colonists, namely the editors of the Natal Mercury, who claimed it as an act of barbarism and injustice (ironic considering the catalyst for the event was seen by the colonial government as having the same characteristics). The use of African customs, such as the "eating up" of other chiefs, was universally condemned as a heathen and barbarous custom "abhorrent to humanity and social justice, and above all, to the genius of our Christian faith." 115 The editors of the Mercury were shocked that the initial reports of this incident were not a "joke," but instead a testament to the despotic nature of the British government in its attempts to rule. This was only fuelled by rumours that the cattle which were confiscated did not even belong to Sidoyi and that the "theft" had left the "unoffending men, women, and children...to perish miserably during the winter now at hand." ${ }^{116}$ Such a response is a testament to the divergent views of the indigenous population which existed in the colony, and is a clear indication of the paternalist nature that existed amongst the white community. Criticism would be even more severe following another similar incident the subsequent year.

What remains important about the Sidoyi incident, however, is the almost overwhelming use of African troops as the primary facilitators of colonial rule. Even when the initial threat had subsided, there were still rumours of a small group residing along the

\footnotetext{
114 “Shepstone Report," Legislative Council, Natal, No. 47, 1857, NCP 4/1/1/1, 1857.

115 The Natal Mercury, May 23, 1857.

116 Ibid.
} 
mountains near the Mshukangubo locality. Shepstone feared spies, or even a counterattack of some kind by Sidoyi himself. Instead of sending any of the European forces at his disposal, Shepstone instead despatched 250 Africans, "under a Native Commander" to make a rapid two night march to the area, capture any remaining cattle, and if possible, locate and capture Sidoyi. Though Sidoyi was not present, there was a small force of 150 men near the forest of the area. Independent of any European authority, the African troops caught the group completely by surprise and successfully drove them off and seized their cattle. As Shepstone praised the actions of his brother and Benjamin Moodie in commanding the troops, he had "every reason to be satisfied with the conduct of the Natives employed on this service; both the officers place over them bear testimony to their zeal and obedience, and I had seldom cause to find fault." ${ }^{117}$ Again, the African troops had proved their viability, and despite criticism from the press, had continued to illustrate their key role in Natal's defensive structure. Though the Sidoyi incident would not have the same controversy of the Matshana incident the following year, it was a shining example of Shepstone's use of African troops to fulfil imperial will while retaining distinct African agency in the parameters of colonial control. The "eating up" of Sidoyi was an act of controlled violence, both settler and African, which indicated the growth of colonial authority in Natal and hallmarked its solidification as a colonial state. ${ }^{118}$

\section{Matshana Incident}

There was little time to consider the long term ramifications of Shepstone and his African troops' actions. Soon after the Sidoyi incident, another problem with a local chief arose in the colony, this time in the northern section of Natal in the Klip River District. In

\footnotetext{
117 “Shepstone Report," Legislative Council, Natal, No. 47, 1857, NCP 4/1/1/1, 1857.

118 Though linked to Shepstone's power in Natal, the use of large numbers of armed Africans, raiding cattle, and "smothering resistance" became a mainstay of colonial rule during Natal's formative period, both by Shepstone and other members of the colonial government. See Guy, Theophilus Shepstone and the Forging of Natal, 256.
} 
December 1857, the mysterious death of a man named Ntwetwe occurred within the territory of Matshana, chief of the Sithole in the Msinga region of the colony. ${ }^{119}$ The death was soon associated with man by the name of Sigatiya, who was purportedly an umthakathi, or one who practices witchcraft. In retaliation, a group of men bound and brutally beat Sigatiya so severely he died. ${ }^{120}$ The incident was reported by Sigatiya's wife to the local magistrate, who immediately began an inquiry. Because of the government stance on witchcraft and its use within the colony, Matshana was called to appear before Magistrate T. F. Kelly and in a similar fashion to Sidoyi, he refused.

Still in the shadow of the Sidoyi incident, it was possibly Matshana's reputation within the colony that contributed to the harsh response to his refusal. Matshana had been cautioned about allowing deaths associated with witchcraft to occur under his jurisdiction in 1850 and three years later was reprimanded by Lieutenant-Governor Pine for the implementation of capital punishment on Matshana's uncle and sons. Pine even proclaimed that "any man who in future wilfully attempts to take the life of another will most assuredly forfeit his own." 121 Matshana's refusal to report to the magistrate in 1857 after the death of Sigatiya was communicated to the lieutenant-governor, who immediately ordered the mustering of troops to force repercussions. Initially, Duncan Moodie was ordered to request a force of men from Langalibalele to assist the government in dealing with the "rebellious chief”. By January, Resident Magistrate Kelly made attempts to meet with Matshana in a final effort to avoid direct conflict. The meeting failed and a larger force was mustered in Pietermaritzburg. In addition to 500 indigenous troops under the command of John

\footnotetext{
119 Known as "Matyana" in the colonial documents.

${ }^{120}$ Moodie's account of the incident can be presented as a somewhat reliable narrative, as he was Clerk of the Klip River District at the time. Duncan Campbell Francis Moodie, The History of the Battles and Adventures of the British, the Boers, and the Zulus, \& C. in Southern Africa: From the Time of Pharaoh Necho to 1880. (Cape Town: Murray \& St. Leger, 1888), 134.

121 "Warning to all Native chiefs concerning punishment for murder." The Natal Government Gazette, September 6, 1853.
} 
Shepstone, 47 men from the Natal Carbineers and Natal Frontier Guard and 38 Afrikaners were sent out to arrest Matshana. ${ }^{122}$ The force departed on January 11 and arrived in the Klip River District on the $18^{\text {th }}$. Theophilus, though not in direct command of the expedition, recommended the use of similar tactics as those used against Sidoyi the previous year. The force would split in two, sweep up opposite sides of the Mzinyathi River, search the areas for Matshana and his supporters, and take cattle as they proceeded. ${ }^{123}$

Matshana quickly fled the district into the Zululand, but remained in contact with his people across the river, limiting the success of the expedition. Some 4,000 cattle, three horses, and 2,000 goats and sheep were seized and the kraal's population dispersed. This effective show of force, however, had failed to successfully capture a chief who had been the source of problems in the past for British authority in the region. The volunteer military corps and indigenous troops performed adequately, with only two African deaths among the total casualties of the initial expedition. In the eyes of the colonial government, the colony had, in essence, effectively prevented a possible military crisis from within. The chief, however, who was the target of the expedition, had escaped again, leading to a continuous fear of his return with possible aid from the Zululand. This was only exacerbated by rumours of a force being gathered by Cetshwayo, future king of the Zululand, coming to Matshana's aid. ${ }^{124}$ Moodie even went as far as to claim that Matshana "like every other traitor to the British Government, found a ready asylum with [Cetshwayo]." ${ }^{125}$ Such aid, however, did not come, but the criticism of the incident from the colonists fostered a debate that would continue decades later.

\footnotetext{
122 Mann, The Colony of Natal, 220-221.

${ }^{123}$ Guy, Theophilus Shepstone and the Forging of Natal, 259.

${ }^{124}$ The Natal Mercury, February 4, 1858.

${ }^{125}$ Moodie, The History of the Battles and Adventures, 138.
} 
Criticism from the pages of the Natal Mercury took the form of questioning the amount of time and the delay of the use of force that resulted, in the opinion of the editors, in the escape of Matshana. The escape of this "petty young chief" could have been prevented, according the editors, by the quick summoning of the Natal Frontier Guard in the region, without the necessity to report to the lieutenant-governor and Shepstone in Pietermaritzburg. ${ }^{126}$ According to the editors, the fault laid in the insistence of the secretary of native affairs in summoning the indigenous military force while also placing it under the command of his brother, who appears to be the source of much scorn from the press. The accomplishments of the Natal Carbineers are commended, but the editors lament the lost opportunities once again in capturing an "impudent young vagabond barbarian" who had insulted the leader of the colony by his refusal to answer a summons. ${ }^{127}$ The memory of Sidoyi still resonated from within the colony and the indigenous troops were an easy target for criticism and scorn in regards to the efficiency of the colony's defensive structures.

If such an editorial is less a criticism of the indigenous military forces and more the administrative policy of Theophilus Shepstone, it remains interesting that the actions of the volunteer military corps were not questioned, and in fact were praised and used as an example of the existing potential of colonial security, despite the evidence that the mustering of the Natal Carbineers was most likely the cause for the delay. Similar criticisms of the efficiency of the volunteers compared to the African troops would be a common excuse during the Langalibalele rebellion as well. Such logic is typical among the European colonists during this period, largely due to their belief that a disciplined group of well-armed, mounted white men could "go any where, do anything, in the territory, beneath British

${ }^{126}$ The Natal Mercury, February 4, 1858.

${ }^{127}$ Ibid. 
rule." ${ }^{128}$ Ironically, such accounts were propagated by the volunteer histories, and not by any direct fault in the African troops. In the official Natal Carbineer history, the march from Pietermaritzburg is presented as a "fair day" event instead one of a military nature, with the troops marching out late in the morning and only arriving in the Klip River district after over five days march. To compare, the Carbineers came across a body of Africans who preceded the main force, and were so ignorant of the composition of the African troops that they were mistaken as spies. ${ }^{129}$ It come as no surprise than that the official history of the Carbineers made no reference to the contribution of the African troops in the Matshana incident, dismissing the vast majority of the force that was responsible for the stabilization of this region in the colony of Natal.

This omission became even more striking when considering the African contribution to an ill planned ambush attempt of Matshana by John Shepstone two months later. John Shepstone and his indigenous forces remained in the Klip River district following Matshana's retreat, but Shepstone held out hope of capturing the exiled chief. A dialogue opened between Matshana and Shepstone, resulting in several meetings. At each of these meetings Matshana arrived with over 50 armed men, making any attempt at capture him considerably unsafe. John Shepstone was eventually able to convince Matshana in April 1858 to meet under less hostile grounds. The plan was for Matshana and his men to leave their weapons a mile away from the meeting place to ensure a peaceful accord. Shepstone, however, had a more nefarious plan in mind. As the meeting commenced, a group of Shepstone's African troops would secure Matshana's weapons, leaving Matshana unarmed and expected to surrender. ${ }^{130}$

\footnotetext{
${ }^{128}$ Mann, The Colony of Natal, 222. It is possible that this incident also posited as a catalyst for the perceived need for a mounted police force in the 1860s. See Chapter Four: European Police.

129 The Natal Carbineers, 38.

${ }^{130}$ Moodie, The History of the Battles and Adventures, 134.
} 
To insure success, John Shepstone hid a pistol under his sitting mat, which would be the main weapon used in the capture attempt. ${ }^{131}$

Despite all of the planning, John Shepstone was unsuccessfully in his attempt to capture Matshana, resulting in the death of 30 of the chief's escorts in what has been termed a massacre. ${ }^{132}$ Matshana fled to the Zululand once again, never to make further attempts at parley with the Shepstones. In the short term, the actions of John Shepstone were praised as part of an attempt to capture this "impudent young vagabond barbarian". ${ }^{133}$ This event, however, would be called to attention later by the Bishop John Colenso following the Langalibalele incident in 1873. Colenso was particularly critical of the manner in which Sir Theophilus "shielded" his brother from the outrage following the incident in 1858, claiming that both Shepstones were responsible for a great injustice. ${ }^{134}$ From what has been described as "spin, cover-up and damage control", the actions of John Shepstone created a rift between the Shepstones and the Colensos and became a point of controversy in the Shepstonian policy for decades to come. ${ }^{135}$ Though the use of indigenous military forces would not be the key issue in the debate, the continuing use of said troops gave a clear indication of the usefulness they provided for the administrative structure of the colony, despite the failures of their administrators and commanders. It cannot be overstated that John Shepstone had no European military support in his attempted ambush of Matshana. His exclusive reliance on

\footnotetext{
131 The weapon is not mentioned in Shepstone's official report, but later inquires revealed this was part of the plan. Shepstone to Lieutenant Governor Scott, April 16, 1858, CO 179/49, 1858.

${ }^{132}$ McClendon, White Chief, Black Lords, 71-72.

${ }^{133}$ The Natal Mercury, February 4, 1858.

${ }^{134}$ George William Cox, The Life of John William Colenso, D.D. Volume II (London: W. Ridgeway, 1888), 380.

${ }^{135}$ Guy, Theophilus Shepstone and the Forging of Natal: African Autonomy and Settler Colonialism in the Making of Traditional Authority, 261-262; For the history of Colenso and the Shepstone, as well as the rift that formed between these two founding figures of the colony, See Jeff Guy, The Heretic : A Study of the Life of John William Colenso, 1814-1883 (Johannesburg Pietermaritzburg: Ravan Press ; University of Natal Press, 1983).
} 
the African military institutions continues to emphasize their importance to not only the colonial policies of defence, but the overall methods of colonial control within Natal.

Both the Matshana and Sidoyi incidents also represented the major means through which Shepstone, and in turn the colonial government, was able to maintain and expand such forces within the colony. With the removals of these two chiefs, a power vacuum was left open by Shepstone and his African troops. For Sidoyi, Shepstone had placed Zashuke, one of his primary induna lieutenants, in command of the area. In turn, Matshana's territory was eventually awarded to Ngoza, one of the leaders of the Mtintandaba, during the 1860s, which he ruled under the direction of Shepstone until his death in $1869 .{ }^{136}$ Shepstone awarded his indunas in the same manner Shaka had awarded his head men during the time of the mfecane. The Zulu military tradition which dominated the colony of Natal, whether directly or indirectly, continued to have longstanding impact on the formation of Natal's military structures, even when the "martial race" ideals of Natal's African populations were imposed from without, instead of within.

\section{The Zulu Militia}

These multiple instances of indigenous rebellion which permeated the 1850 s were directly or indirectly related to the colonial government's call for new forms of defence, taking the form of volunteer corps and later mounted police. There were still, however, those who advocated for a military presence of Africans to aid in the defence of not only Natal, but the Empire. In October 1858, Captain J.H. Browne and Lieutenant Colonel and Commandant J. Palmer presented two separate letters to Lord Lytton at the Office of the Secretary of State

\footnotetext{
${ }^{136}$ Though Ngoza's death did lead to a major problem with his hereditary heir and the transition of authority in the appointed chief system under Shepstone. See Guy, Theophilus Shepstone and the Forging of Natal, 469.
} 
for the Colonies. ${ }^{137}$ Both men were members of the South Mayo Rifles, an Irish militia stationed in the Castlebar Military Barracks and affiliated with the 88th (Connaught Rangers) Regiment of Foot. Both schemes involved the stationing of the Mayo Rifles in Natal and the raising of a "Zulu" militia that would be the blueprint for a militarized camp system within the colony and allow for the preparation of African troops to be sent across the Empire, particularly India (as an alternative or supplement to the Sepoy who had just been defeated in June). The manner in which these two officers present their plan, and the response from the British government, is illustrative of not only the perceptions of the Africans in Natal as a "martial race" within the British Empire, but also telling of the perceived shortcomings of the existing military systems in the colony of Natal.

Though Palmer and Browne made principally the same proposal to the Colonial Office, the context in which they placed the scheme was somewhat altered. Palmer argued that in the event of a European war, the British Army was "insufficient to defend the extremities of the empire" with a population of 3,000,000 contained by an army of only a 100,000 (including the 75,000 in India). ${ }^{138}$ With that in mind, Palmer argued that troops that could deal with the hot climates across the globe would be a worthy investment for the Empire. Palmer pointed to Natal, which by his estimates contained "a population of Zooloos [sic] \& Basutos of between $200 \& 300,000$ among whom are estimated 48,000 warriors." Interestingly, Palmer argued that the answer to concerns for systems of security within the colony of Natal would be the recruitment of these "hardy African troops" for the service of the Empire. It is almost impossible to consider where such a scheme came from, but Palmer believed that the officers of the South Mayo Rifles would be ideal candidates in the formation

\footnotetext{
${ }^{137}$ Captain Brown addressed his letter to Lord Stanley, who had left the post for the position of President of the Board of Control for India in June.

${ }^{138}$ J.R. Palmer, Lt. Colonel and Commandant, South Mayo Rifles to the Right Hon. Sir E Bulwer-Lytton, October 13, 1858, CO 179/50, No. 10625, 1858.
} 
of an African militia that would be the cornerstone of these new African regiments (despite none of these officers having any experience with African languages). With the confidence Palmer had in "the strongest regiment of Irish Militia excepting one", the British government could place its faith in the South Mayo Rifles forming this grande armée of the Empire. ${ }^{139}$ Ideally, the South Mayo Rifles would relieve the existing British troops in Natal, while also taking upon themselves the task of forming a second, African battalion of equal strength, with European officers appointed amongst the colonists by the governor, selected of course "from persons conversant with the native language". ${ }^{140}$ As for the recruitment of Africans, Palmer argued that the officers of the Mayo Militia had ample experience in recruiting during the "last war" (presumably the Crimean War) in the Curragh Camp in Kildare and Dublin. Palmer made the general assumption that recruitment techniques would be similar, as this is the only viable experience offered for the plan. From this battalion, Palmer recommended the formation of military farms on government land, where the African recruits could be set to the task of cultivating cotton under the supervision of their officers.

Expectations for the growth of cotton were typical during this period. Some 30,000 acres were granted by the government to the Natal Cotton Company in 1847 . High expectations, however, resulted in lacklustre sales figures. Also, many of the labourers who were brought into the colony to cultivate the land had little to no knowledge of cotton; their expertise lying more in oats, rye, potatoes and beans. The company soon withdrew its request for crown land and eventually the cotton industry itself would collapse by the 1860 s. ${ }^{141}$

Palmer argued that the military code that the Africans would work under could act as a bridge to the more "complicated civilization of the civil law" as soldiering was more

\footnotetext{
139 Ibid.

${ }^{140}$ Ibid.

${ }^{141}$ See Hattersley, The British Settlement of Natal, 86-87.
} 
adapted to "the ideas of a barbarian". ${ }^{142}$ This logic led directly to Palmer's belief that the martial race characteristics of the "Zulu" were ideal for military life, as it had been attained under the rule of King Shaka. More importantly, the "seeds of civilization", which these institutions developed, would lead to prosperity for both the Africans and the increase of European enterprise and profitability, moving the Southern African economy away from the traffic of slaves and into more civilized tasks of produce cultivation. For Palmer, this process would need five years to take root, with the establishment of the Mayo Rifles in Natal and the eventual creation of the first African Militia, numbering around 300 men. After this five year period, the Mayo Rifles would be incorporated with the army and be responsible for an "African Legion" numbering 2,000 men. The short term impact of the program would be the providing African troops to all segments of the Empire, namely India, but the grander goal of the program was the act as "pioneers in a new road to a field for recruiting" within the Empire. ${ }^{143}$

Captain Browne's letter was presented with almost the exact information, including the numbers of Africans and viable warriors in Natal. Instead of beginning his recommendation in light of the growing military concerns within the Empire, Browne instead pointed to the growing population within Natal and how "history shows them to be capable of military discipline". ${ }^{144}$ More importantly, Browne emphasized the plan's viability rested on the key characteristics exhibited by the Africans of Natal: the "prestige of England among South African tribes", the Africans adaptability to "service in hot climates," their nearly overwhelming numbers, and their "freedom from religious animosity to Europeans". ${ }^{145}$ Such characteristics made the Africans of Natal ideal for replacing British troops in India and

\footnotetext{
${ }^{142}$ CO 179/50, No. 10625, 1858.

143 Ibid.

144 W.H. Browne, Captain, Mayo Rifles to the Right Hon. Lord Stanley, October 24, 1858, CO 179/50, No. $11021,1858$.

145 Ibid.
} 
beyond. Browne also emphasized the impact on commerce and diminishing of the slave trade such forces would provide for Natal.

Despite the passion exhibited in both proposals, the War Department had no interest in such a scheme. After the proposals of Captain Brown and Lt. Col. Palmer were forwarded to the secretary of state for war, they were informed the next month that the government was "unable to entertain the proposal". ${ }^{146}$ In private correspondence within the colonial office, the proposal was described as a "wild scheme" which should not even be presented to the War Department. The primary concerns from the Colonial Office rested in the idea of arming Africans in a European style, which was essentially seen as "preparing a fresh Army of Sepoys to revolt against us...but Sepoys consisting of hardy Africans instead of timid Hindoos". ${ }^{147}$ Even those within the Colonial Office who saw the appeal of indigenous troops insisted that it was impractical to consider stationing the African troops in their own country, for the simple condition of safety. A "Zulu regiment" could perhaps work, but only if they were stationed "at Gibraltar and other posts of the same kind". ${ }^{148}$ The plan, in simplest terms, was too dangerous and too impractical to be even considered.

Such recommendations could be dismissed as absurd, or even laughable. Yet they are illustrative of the perceptions that existed within the imperial mind which envisioned a use for African troops within the colony of Natal and the Empire. Browne and Palmer both had substantial misconceptions regarding the Africans of Natal (the generalization of "Zulu" being just one). This was not for lack of trying. Captain Browne including in his proposal multiple segments of information from the Colonial Blue Books regarding the "State of the Kaffir Tribes", underlining quotes from Livingstone and the Reverend Shooter regarding the

\footnotetext{
${ }^{146}$ War Office to Captain Browne, November 18, 1858, CO 179/50, No. 11847, 1858.

147 "Natal," CO 179/50, No. 10625, 1858.

148 Ibid.
} 
"noble figures" of the Zulu and the military abilities of the people of Southern Africa. ${ }^{149}$ Perhaps more importantly, the aspirations of Palmer and Browne to become a part of the military establishment of the colony of Natal are evident in their letters. Browne, who includes his card as "Mr. J. Howe Browne, 39 Rutland Gate, Hyde Park", was seemingly no longer an active member of the Mayo Rifles, and saw this as an opportunity to improve his lot in the Empire. Palmer, almost on the verge of pre-emptive nostalgia, declared that the officers of the Mayo Rifles would be rewarded with their commissions in the army which they would "devote the best years of their lives" to the execution of the scheme. ${ }^{150}$ Such expectations reveal that the African in Natal, like so many other colonial troops in the nineteenth century, remained an avenue for imperial careering.

It should be noted that the "Zulu scheme" was not the only attempt to make use of forces available to the British. Obviously individuals like Palmer and Shepstone appreciated the use of indigenous forces within the colony (despite the variations of their systems of control). This, however, did not translate to a total advocacy for non-white troops within the colony. As we have seen with the failed attempt to create an Indian Volunteer unit, there were also plans to supplement both white and African troops in Natal during the 1860s. In 1867, the Select Committee of the House of Commons on the Indian Army and the Colonies made inquiries into the viability of stationing troops from India into other parts of the Empire, a pragmatic solution to the limitations of manpower in the ever growing imperial dominion. In a response to a questionnaire submitted by the committee, Shepstone admitted that the use of Indian forces within Natal would not be a very wise decision. ${ }^{151}$ Citing the African resentment that already existed toward Indian labour in Natal, Shepstone feared that the

149 "Extracts for the Blue Book of the State of the Kaffir Tribes, 1857, Also from the last Blue Book on the State of the Colony of Natal," CO 179/50, No. 11847, 1858.

${ }^{150}$ J.R. Palmer, Lt. Colonel and Commandant, South Mayo Rifles to the Right Hon. Sir E Bulwer-Lytton, October 13, 1858, CO 179/50, No. 10625, 1858.

${ }^{151}$ BPP: Reports from Committees: Army (India and the Colonies), 1867. 
presence of Indian troops would fuel anger as well as rebellion, which the Africans "might otherwise not have attempted." 152 Shepstone attested that the most reliable troops raised for the defence of the colony would be those from the colony itself, with the stipulation that white officers would be expected to lead them. The apprehension felt in regards to the Indian troops was most likely not the result of lingering fear from the Indian Mutiny ten years before, but instead related to a deeper understanding of the indigenous population of Natal that Shepstone was largely renowned for. Shepstone's understanding of the Africans, even by the 1860 s, was still seen as the most informed opinion within the colony of Natal. Even the infamous Langalibalele Rebellion would do little to diminish Shepstone's credentials or alter the importance of African troops to the safety and security of the colony.

\section{Africans in the Langalibalele Incident}

Perhaps one of the most haunting and telling events of the formative period of Natal, the Langalibalele "Rebellion" of 1873 represents a primary turning point in the place of Africans within the colony of Natal, in both the sense of its own protection and the fear of the indigenous population from colonial settlers. The Langalibalele incident has already been discussed in previous chapters, but it is important to understand the basic premises to better contextualize African participation in putting down the rebellion. Though the conflict between the Hlubi and the British administration was the primary motivator in this incident, it was the response by the government which created its infamy in the eyes of many colonial settlers. ${ }^{153}$ Though producing one of the most complete accounts of the motives and outcomes of the incident to date, Jeff Guy rightly points out that though these Africans were

\footnotetext{
152 Ibid., 241.

153 The previous volunteer chapter has discussed this component of colonial consciousness, but specifically omitted the African participation for reasons of clarity.
} 
crucial to the enterprise of putting down the rebellion "the details are few and it is difficult to reconstruct."154

From what has already been discussed, the Langalibalele incident was representative of a clash of indigenous and colonial forces over the issue of sovereignty and more importantly the rights of defence. John Macfarlane, Resident Magistrate at Estcourt, demanded in 1873 that Langalibalele, a powerful chief between the Bushman's and Little Thukela Rivers, turn in all unregistered firearms under Natal's Gun Laws. Much like the Sidoyi and Matshana incidents, Langalibalele refused. As has been previously noted, what made this incident so unique was the place Langalibalele held within Shepstone's system of military defence. The Hlubi had assisted Shepstone on multiple occasions, most notable the Matshana incident of 1858 (see above). When called upon in the same manner, the chief refused. The source of Langalibalele's actions has been a constant debate within the historiography, but it can be assumed that pride and ego dictated the actions of both sides leading up to the incident. Though the racial composition of the volunteers clearly defines their actions during the rebellion, it does little to explain the African response, or perceptions of their response, from the majority of the population within the colony of Natal. It must be emphasized that Langalibalele was a respected member of the indigenous community. Though he had fled into the colony during the Mpande incursions of the late 1840s and been forced into the Drakensberg location in 1849, Langalibalele had achieved resounding success for both himself and the people under his charge. Sadly, it was this success verging on prosperity that contributed to the eventual harsh repercussions against Langalibalele and his people.

${ }^{154}$ Guy, Theophilus Shepstone and the Forging of Natal, 393. 
As has been previously stated, the catalyst for the harsh repercussions against Langalibalele and his people can be traced to the incident at Bushman's Pass. Three volunteers and an interpreter were killed in what amounted to an act of folly by the British colonial officials, combined with the over confidence of the Natal Carbineers. ${ }^{155}$ Much was made by Major Durnford's report that orders were given "not to fire the first shot", but it was in all likelihood the failure of the volunteer's discipline that contributed to the "disaster". ${ }^{156}$ For many, it was the failure of Captain Allison's African troops to properly arrive on time to assist Durnford that gained the most scorn from the colonial population. Pine even went as far as to describe "the true cause of this disaster was the fatal mistake in the plans which prevented Mr. Allison and his large native force being on the spot to meet and support the volunteers." 157 One contributor to the Times of Natal dismissed any fault on the part of the volunteers, but instead cast the volunteers as a support group that was simply abused by its connected African force. Whereas much had been said about the order "not to fire the first shot" with reference to the disastrous occurrence at the head of Bushman's River Pass, the contributor to the Times argued that if examining the Durnford's orders further, one would realize that "the volunteers were sent to support the civil power in the arrest of a rebel; the civil power were supposed to be an armed force of native police." ${ }^{158}$ Since the Carbineers were sent to the pass to support a body of Africans under Captain Allison, the orders meant that the African troops would have to be the ones who would act fist. Since the orders never contemplated the volunteer force being opposed alone, there was no reason for Durnford to act as conservatively. In fact, the contributor went so far as to suggest that since a small

\footnotetext{
${ }^{155}$ See Chapter Three: Volunteers.

${ }^{156}$ BPP: Papers Related to the Late Kafir Outbreak in Natal, 1874, Enclosed in No. 11 Lieutenant Governor Pine to Early Kimberley, For Major Durnford's report on the incident at Bushman's Pass, November 30, 1873.

${ }^{157}$ BPP: Cd 1025, Papers Related to the Late Kafir Outbreak in Natal, 1874. No. 11, Lieutenant-Governor B. Pine to the Earl of Kimberly, November 13, 1873.

158 "Notes on 'The Langabellala [sic] Expedition"”, (Reprinted from The Times of Natal), The Natal Witness, December 5, 1873.
} 
contingent of Sotho was present, they should have been sent first, asking: "Would not the employment of this small force in attack have been within the means of the order, and have avoided any imputation of disobedience?"159 Even when critical of Durnford and the volunteers, responsibility still fell upon the African, ostensibly because there was no voice to defend their actions directly in the press.

Though it remained McFarlane's primary responsibility to draw up the forces from the local chiefs during the rebellion, it was a focus within the colonial government to bring about a large body of indigenous levies to participate in the formal putting down of Langalibalele and the Hlubi. This mustering was made more feasible with the declaration of martial law by Lieutenant-Governor Pine in November. Two flying columns, composing of largely Africans led by local magistrates, would be the primary response force that hunted down Langalibalele. Forces were mustered from around Pietermaritzburg, Estcourt, and the Klip River District. The appointed chiefs saw this as an opportunity to maintain their place within the British administrative structure, but also solidify claims to their own land and the opportunity for plunder and cattle. One group, the Mchunu of Phakade, had even taken part in driving the Hlubi into their location twenty years before. ${ }^{160}$ Now it was their goal to drive them out.

It would be an oversimplification to say that the response against the Hlubi was a simple continuation of the actions by Shepstone against the likes of Sidoyi and Matshana. The atrocities committed by the Africans and volunteers during the rebellion were ones that had been carried out in a multitude of colonial settings, including Natal: looting, seizing of livestock, and the forceful removal of people. Thousands of heads of cattle were seized, kraals were burned, and women and children were captured and forcibly removed. By the end

${ }^{159}$ Ibid.

${ }^{160}$ Guy, Theophilus Shepstone and the Forging of Natal, 393. 
of December, Langalibalele was captured, and by the end of April, he and seven of his sons, two of his indunas, and some 200 followers were sentenced to various types of imprisonment, with Langalibalele most notably being sentenced to Robben Island in the Cape Colony. Langalibalele's trial would cause more turmoil in the colony, but the incident was essentially concluded. ${ }^{161}$

Though the death of the volunteers at Bushman's pass had been labelled "a sad catastrophe", this attack against the Hlubi people was seen as a fitting repercussion, in light of Pine's report to the Earl of Kimberly:

Our forces have, in small skirmishes with the remainder of the tribe hidden in caves and strong fastnesses, been everywhere successful, killing a large number and taking some men and an immense number of their women. No men, however, have been killed unless with arms in their hands, but I regret that their number has been so considerable. ${ }^{162}$

Ironically, where the African forces under Allison were presented as the "fatal mistake" which led to the deaths of the volunteers at Bushman's Pass, Pine strongly emphasized the two flying columns of African troops which were sent out against Langalibalele, even praising the services of Shepstone along with "the services which the native contingents afforded me [Pine]." 163 In December 1873, toward the conclusion of the rebellion, Captain Allison also praised the contributions of the African troops, by that point numbering 1,600

\footnotetext{
${ }^{161}$ For a more in depth examination of the trial and its impact on Natal See Guy, The Heretic: A Study of the Life of John William Colenso, 1814-1883; Cox, The Life of John William Colenso, D.D. Volume II.

162 BPP: Cd 1025, Papers Related to the Late Kafir Outbreak in Natal, 1874. No. 11, Lieutenant-Governor B. Pine to the Earl of Kimberly, November 13, 1873.

${ }^{163}$ BPP: Cd 1025, Papers Related to the Late Kafir Outbreak in Natal, 1874. No. 11, Lieutenant-Governor B. Pine to the Earl of Kimberly, November 22, 1873.
} 
men. Though suffering hardships in the mountains due to improper clothing, there was no open dissent, and only "one case of punishment for neglect of duty."164

The failure of Allison to arrive on time did little to the importance of African troops to the putting down of the Hlubi, and did not limit the number of African troops mustered in response to the rebellion. This becomes striking when looking at the importance of African troops to the colonial military plan during the incident. Instead of acting as a supporting force, African troops were the primary military institution in the plans of Commandant Miles. This included 500 Africans under Allison, Lucas, Macfarlane, and Hawkins, all resident magistrates of their districts respectively. They would be supported by volunteer and regular forces, and not vice versa. This was not a dramatic departure from the use of African troops in the Sidoyi and Matshana incidents, but it shows a clear shift from the apprehensions shown in 1851 against the colonial levies. This shift is particular telling in regards to the response of many colonists to the destruction in the post-Langalibalele incident, including pillaging and cattle theft.

The repercussions for Langalibalele's flight did not end with the chief's capture. The defeat of the Hlubi created what amounted to socio-economic vacuum in Natal. Though white colonists were more than happy to take over the location land and begin farming, Africans taking part in the suppression of Hlubi forces also saw opportunities for economic gain. The payment of cattle was the major means of compensation by magistrates and officers within the indigenous levies, and additional plunder was seen as a means of appeasement and continuing cooperation between the European and African military forces within the colony. One such incident involved an African force attached to Captain Lucas' command in late December of 1873 .

${ }^{164}$ BPP: Cd 1025, Papers Related to the Late Kafir Outbreak in Natal, 1874. Enclosure 1 in No. 35, Albert Allison, Commanding Pursuing Column to Secretary of Native Affairs, December 20, 1873. 
In May 1874, Mr. Scott of Geluk Farm forwarded a complaint to lieutenant-governor regarding a "native force" under the command of James Gregory from the Klip River County. Scott contended that on December $20^{\text {th }}$, this group "destroyed the whole of the household stuffs and clothing of his [Scott's] native tenants as well as part of their live stock, ill-used the native themselves and threatened their lives, one Native being murdered by the said party on or on the verge of the Farm." 165 Despite the likelihood of such complaints following the actions of many military personnel during the rebellion, HC Shepstone, Theophilus' son and Resident Magistrate of Ladysmith, when inquiring into the accusation, discovered some discrepancies. According to Gregory, his troops were not near the Geluk Farm on the $20^{\text {th }}$, though he did pass the night at Scott's home the night of the $23^{\text {rd }}$, where Scott spoke to Gregory about his losses, and even offered to bring the owners of the kraals that had been robbed down the Tugela "the following morning that they might identify the offenders and...punish them." ${ }^{166}$ The next day Scott, however, arrived at the Tugela Punt (floating bridge), and informed Gregory that no complainants were coming, after which Gregory left.

Why the discrepancy? It is probable that Scott himself was not at the farm when the troops came through, and did not mention Gregory's arrival later due to either absentmindedness, or even the perception that it was not pertinent due to the lack of any conclusive outcomes. The complaint, however, could be used as conduit for further problems with the colonial government, including grievances about the manner in which African cases were handled by the magistrate, or even the simplicity of a gun charge which H. Shepstone simply states he could not address in the grievance. Time could also have been a relevant factor. Though the initial complaint had been put forward in May, it was not until October

\footnotetext{
${ }^{165}$ Shepstone Papers, Correspondence re Mr. Scott's complaint about a Native force, 1874. KCM 31486, Killie Campbell Library, Durban, South Africa.

${ }^{166}$ Shepstone Papers, From H. Shepstone to Mr. W. Scott, 1874. KCM 31474, Killie Campbell Library, Durban, South Africa.
} 
1874 that Shepstone began addressing the issue. This was nothing extraordinary, as the colonial government was still dealing with the repercussions of the Langalibalele incident well over a year later, prompting some complains to be backlogged or simply forgotten. The Geluk Farm incident is perhaps most revealing of the perceived versus actual role of the African troops in the rebellion, as well as the inability of many colonists and Africans to differentiate between rebel and collaborator.

According to Shepstone's report to the Secretary of Native Affairs (his father Theophilus), Captain Lucas during the rebellion had granted a pass to the indunas of many kraals of the Hlubi who reported themselves as unwilling to take part in the resistance to the colonial government. Such passes guaranteed both the safety of themselves and their property as long as their kraals remained neutral. Amongst these kraals included the Silonda, Sotemela, Undaba, Uklacs, and Uqitywa of Geluk Farm. ${ }^{167}$ On further examining and interviews, Shepstone discovered that the acts of theft on the farm were committed by a small party of Mclwyzi's men under an induna named Umginqizane. The probable reason Gregory's force was implicated in the incident was their presence in the neighbourhood the same day examining kraals and searching for rebels. Mclwyzi's men could not be called upon to corroborate, as they were in Pietermaritzburg and appeared to be under the protection of another chief outside the jurisdiction of H. Shepstone's magistracy. As for the murder, this remained unclear, as Shepstone contented there was little evidence that proved either a party of Gregory's men or those under Umginqizane were responsible. The only detail know for certain was the man's death was violent and unjustifiable as the victim was unarmed. Though compensation was provided for the loss of property, a total of $£ 810 \mathrm{~s}$. for the five men, there was no conclusive evidence or prosecution for the death of the African. Despite the fact that

\footnotetext{
${ }^{167}$ Shepstone Papers, From H. Shepstone to Secy Native Affairs, (Mr. Scott's complaints), October 29, 1874. KCM 31486, Killie Campbell Library; Durban, South Africa.
} 
the African forces were ostensibly cleared of wrongdoings, the cloud of possible violence still resonated in the area almost a year after the Langalibalele rebellion.

All of these incidents, combined with the activities by the African units during the rebellion itself, showed the heavy reliance the colonial government had on these African defensive institutions. It would not be an exaggeration to state that without the involvement of Africans in the capture and dispersing of Langalibalele's forces, Shepstone and the colonial government would lack the resource necessary to impose their colonial will. It remains telling, however, that the African units, despite their assistance, remained the source of blame and apprehension from large segments of the colonial society. Perhaps this was simply deflection on the part of the colonial population, or the product of a racialized world view. Perhaps, more likely, it was the revelation that Langalibalele, a long-time ally to Shepstone, would just as quickly become a threat the emerging colonial state. It was no surprise than, that the continued use of African troops created such apprehension and debate throughout the formative period.

\section{"A Pretorian Guard of Savages"}

The debates which raged in Natal over the use of African troops remained a heated issue throughout the formative period of the colony. The Sidoyi, Matshana, and Langalibalele incident all illustrated the need and practicality of the indigenous defensive institutions. Much like the African police, however, African troops were seen as a danger to the peace and security of the colony. The criticisms that had boiled over regarding the African levies in the 1850s had not subsided decades later in the shadow of the Langalibalele incident. Though the far-fetched schemes of the Zulu Sepoy style regiments were dismissed before any proper implementation, the continuing reliance on African troops posed an even greater problem for white settlers. As the volunteers and burgher forces were seen as a counterbalance to the 
necessity for a standing army, the African troops were seen as a dangerous crutch for the colony.

Oddly, the colony and its government remained on a precarious position of equilibrium by the conclusion of the 1860 s and moving into 1870 . The report of a commission appointed by the lieutenant-governor to inquire into the state of the colonial forces and defences in 1868 found major faults in the volunteer systems and regular colonial forces, calling upon the construction of more laagers in all counties and stating the present volunteer system was "very defective in respect to organization, efficiency, [and] disciple."168 Ironically, laagers were seen as the best means of protection as the settlers were "scattered among the native tribes of Natal" which at this point had reached 250,000 Africans compared to 15,000 Europeans and 6,000 Indians. ${ }^{169}$ Even with this impending threat, the commission reported that "native tribes have an organisation of their own sufficient for present purposes, and that it would be unwise to disturb their natural arrangements." ${ }^{170}$ Despite all the criticism, nothing was officially changed in the indigenous military systems. Whether this was the result of neglect or ignorance remains unclear. Theophilus Shepstone served on this committee, which submitted its report in March 1869, though it is unlikely he had any problems with his own system of indigenous troop management as he remained the de facto leader of any such organization.

It is important to note that the questionnaires sent out to resident magistrates regarding to topic of colonial defence included information relevant to the African military forces within the colony. The lists of question for the commission included descriptions of

\footnotetext{
168 "Report of a Commission appointed by his Excellency the Lieutenant Governor to inquire into the present state of the Colonial Forces and Defences, and for that better organization thereof.-1868." The Natal Government Gazette, June 8, 1869.

${ }^{169}$ Ibid.

${ }^{170}$ Ibid.
} 
the colonial force in their country or division as militia, burgher, volunteer, African, or a combination, whether military forces should be raised from the African population, and if so, on what principle, either armed, mounted or unmounted. ${ }^{171}$ Ironically, many of the later questions not pertaining to the volunteer forces focused almost exclusively on the "native forces”, including preventative measures insuring minimal panic amongst the African population in the case of invasion, or whether "a paid infantry force, officered by Europeans...could thorough dependence be place upon their fidelity, if property selected."172 In spite of these questions, the committee made little comment on the importance of indigenous troops the following year.

Even in the Report of the Select Committee upon the Financial State of the Colony in July 1869 no mention is made of the indigenous contribution to colonial defence. The committee recommended limiting Shepstone's powers as Secretary of Native Affairs, though this was nothing new in the continuing conflict with Shepstone and his detractors. The greatest concern regarding colonial defence was the possibility of the small body of imperial troops being withdrawn from the colony, throwing "the burden of preserving the peace of the country upon a small number of white inhabitants, surrounded on all sides by uncivilized native tribes." 173 This ignorance or dismissal of the indigenous forces, as has been shown, was nothing new. Nonetheless, this period was chiefly characterized by the call for reform and changes within the colonial system, as has been shown for both the volunteer and police institutions. The following year, two bills related to defence were introduced, one for the better regulation of the volunteers, and the other "For the better defence of the colony." The

\footnotetext{
171 "Notice: To the Resident Magistrate of Counties and Divisions of Natal- Questions by the Commission Appointed by Government to Enquire into the System of Colonial Defence, \&c., March 16, 1868.” The Natal Government Gazette, March 31, 1868.

172 Ibid.

173 "Legislative Council-No. 5, 1869: Report of Select Committee appointed to consider the Financial State of the Colony, July, 27, 1869.” The Natal Government Gazette, August 3, 1869.
} 
second bill principally attempted to create a system in which all able bodied white men would be capable of joining a military detachment in times of need, or simple be "armed and liable to be called out for active service when required." 174 The bill was never ratified (unlike its volunteer counterpart), but the complete dismissal of African troops is again glaring.

Within the public debate, however, Africans were not ignored, but instead cast as the worse possible solution to the problems of defence within the colony. When discussing the new military tactics used during the Franco-Prussian War of 1871, the editors of the Witness lamented the new technology, tactics, and science of the war which was not being implemented within the colonies. Though England had a strong military tradition:

at present, in Natal, the Executive seems to be undecided whether the defence of the colony, against internal enemies, should be undertaken by the Home or the Colonial Government; and, if the local authorities were left to themselves (which, of course, they could not be) they would probably begin to inaugurate a plan of defence after the Governor had been either scotched or killed by the enemy, and not before. ${ }^{175}$

Perhaps most threatening to the European population was not the possibility of an armed African force, but instead the lack of a proper implementation of discipline and fear to insure the submission of the local African population. The colonial government, in the opinion of the editors, had done nothing "to place the defence of the colony on a satisfactory footing, by preparing the colony for attack, or by weakening the powers of the Kafirs."176 Africans no long "feared" the "white man" because their defeat by the Afrikaners decades before had diminished in the collective memory. ${ }^{177}$ Instead, the Africans had forgotten, and in turn become "to a great extend armed with European weapons... [and remained] under their

\footnotetext{
174 “Bill—'For the better defence of the colony', June 18, 1870." The Natal Government Gazette, June 14, 1870.

175 The Natal Witness, April 2, 1872.

176 Ibid.

177 This was as direct reference defeated the Zulu kingdom under Dingane on December 15, 1838 at the notorious Battle of "Blood River" on the River Ncome.
} 
hereditary chiefs." ${ }^{178}$ Of course, the editors of the Witness did not venture to claim whether such conditions made them less or more defiant, but left the answer to their readers' imagination.

Criticism rested on the current government policy that had done nothing to remove the ongoing, imperceptible threat of the African but instead had only addressed emergency threats, such as the Sidoyi, Matshana, and Langalibalele incidents. Questions continued to be raised, which still resonated from the previous decade: "Have all or any of the natural fastness, in which the native are located been penetrated by good roads? Are our volunteers as well organised and armed as is possible? Have any efforts been made to facilitate the construction of railways?" ${ }^{179}$ All answers were in the negative, but for many of these infrastructure concerns, the colonial government was not entirely to blame before 1867 (largely due to the financial problems of the colony). Recommendations from the editors remained focused on the reliance on Europeans, with the encouragement of the burgher forces being organised by the Afrikaners (which have already been revealed to be ineffective for much of their existence in the colony) and the involvement of English and German colonists in "every possible effort should be made to get up an efficient volunteer corps, that should comprise of all classes." ${ }^{180}$ As was typically the case, suggestion were made for monetary grants which focused on the protection of prospective neighbourhoods, citing that cost savings would be better than the current system.

Of course, as has been previously discussed, such initial monetary investment was highly unlikely for most of the formative period of the colony. The level of anxiety expressed by the editor, however, ultimately extends to the belief that the colony should be less

178 The Natal Witness, April 2, 1872.

${ }^{179}$ Ibid.

${ }^{180}$ Ibid. 
dependent on "native police" and African troops, described as being fuelled by "tribal antipathies" which allowed for the alliance with other African leaders and the "eating up" of other chiefdoms. If the African troops were allowed to continue this system of influence, without being properly balanced against a European police force, the editors of the Witness believed the colony was "training a Pretorian guard of savages, who, no doubt will, if the system continued, do as such forces have ever done." 181 What the editors of the Witness continually ignored was with such an analysis; Shepstone was the "emperor" of the colony, not the Lieutenant-Governor, a fitting, if somewhat exaggerated metaphor to Natal's colonial power structure.

Just as the white population of the colony was concerned with an African arresting a European, the colonists of Natal were fearful of being usurped by the established military systems which predated their arrival in the colony. Though such systems had only slightly evolved since European arrival, the consistency of African military tradition remained an intimidating, if not outright threatening, prospect to the legitimacy of British rule. The combination of a fear of an invasion from the outside and within was only exacerbated by the inherent problems that existed within the European institutions of control. The Langalibalele rebellion provided fodder for greater criticism of indigenous troops, but did little to relieve the colony's own concerns for their own military traditions, despite all claims to the contrary from the parts of the media and many colonial administrators. Though the catalyst for military reform, including the greater formalization of the volunteer system and the implementation of a more professional mounted police, the Langalibalele incident did not change primary military structures of the colony. African troops of the colony of Natal would remain the most significant component of the colony's defensive institutions, and would be crucial in the British invasion of the Zululand in 1879.

181 Ibid. 


\section{Conclusion}

This chapter has demonstrated that the use of African troops and their contribution to the colonial order had a significant impact of the forging of Natal as a colonial state. It would be remiss, however, to ignore the African contribution to the most iconic incident of this formative period of the colony: the Anglo-Zulu War of 1879. The largest effort to mobilize the Africans into a semi-formal military organisation was the Natal Native Contingent (or NNC). Though largely forgotten in the collective memory of the war, over half of the 17,000 troops commanded by Lord Chelmsford that marched into the Zululand in January 1879 were Africans. ${ }^{182}$ Considered "black auxiliaries", the NNC was placed under the command of Colonel Anthony Durnford and headed by European officers and NCOs. The main trust of the contingent included three "lines" which contributed to the three major invasion columns, numbering about 2,000 men each. A major divergence from previous deployments was the organization of over 1,300 "mounted natives", consisting of eight companies, though 800 of these men were part of the "transport service" and "pioneer corps" that was associated with the Royal Engineers. All told, the NNC consisted of 8,187 men, including 14 white officers. ${ }^{183}$

Despite the size and organization of this contingent, these African troops were given no uniforms, save a red headband to distinguish them from the Zulu, and only one in ten were given rifles. The remaining men were forced to fight with traditional throwing spears and shields, resulting in cases of the members of the NNC being mistaken for Zulu troops in the heat of battle. The limited success of the NNC appeared largely the result of the inability of

\footnotetext{
${ }^{182}$ Ironically, the most famous member of the contingent was one of its white officers; a Swiss man named Christian Schiess who received the Victoria Cross at the Battle of Rorke's Drift. See Morris, The Washing of the Spears, 305-306.

183 "Summary of Colonial Forces (European and Native) raised under the authority of this Government During the Zulu War, 1879, Legislative Council, No. 9, November 17, 1879”, The Natal Government Gazette, November 25, 1879.
} 
the British command to fully implement them into the traditional British military organization. ${ }^{184}$ Though they were expected to make major contributions to the war effort, the overall impression of their use has rightly been described as rife with "authoritarian stupidity and racist exploitation." ${ }^{185}$ The $\mathrm{NNC}$ was also never able to be effectively used as a scouting force during the campaign, instead being used as manual labour instead of soldiers, particularly the pioneer and transport units. This was a consistent theme of African troops throughout the military history of the British Empire and not just Natal. ${ }^{186}$ Over 3,000 Africans were also used for "various Army Services", including an additional 2,291 used for transport and hospital services, and 724 men for the "Special Pioneer Service, on the Roads used by the Military within the Colony." 187

If the NNC could be perceived as a failure, it did not diminish their overall importance to the war. Despite part of the troops being nearly wiped out in Chelmsford's second column at Isandlwana, they remained an active part of the continued invasion for the remainder of the year. Discipline, of course, was also a factor, as was the case with any levied troops, African or otherwise. ${ }^{188}$ The fleeing of African troops from the Zululand into Natal after the disaster at Isandlwana contributed to the panic which subsidized the fear of Zulu invasion with Natal's white population. But they were no less dramatic than the desertions of British members of the invasion force, including the white volunteers. Lieutenant-Governor Bulwer even praised the "Native Auxiliaries" for their "good service" and assured all

\footnotetext{
${ }^{184}$ For a more the most complete account of the NNC and their role in the Anglo-Zulu War, see P. S Thompson, Black Soldiers of the Queen: The Natal Native Contingent in the Anglo-Zulu War (Tuscaloosa: University of Alabama Press, 2006).

185 Guy, Theophilus Shepstone and the Forging of Natal, 477.

${ }^{186}$ Even in Natal, there was apprehension about the militarization of labour units, but it was deemed necessary to make an unpopular duty attractive. See Thompson, Black Soldiers of the Queen, 18.

187 The Natal Government Gazette, November 25, 1879.

${ }^{188}$ This is counter to more established African forces, like the King's African Rifles, whose "special 'talent' was their willingness to military discipline", See Parsons, Social Implications of Colonial Military Service in the King's African Rifles, 1902-1964, 5.
} 
participants that "the memories of those who fell, and the circumstance of those whom the war has bereaved, claim our warmest recognition." 189 Though the Natal Native Contingent was an important component of Natal's defence in the war, it does not even include the over 10,000 Africans called up for the "Native Levies". These included forces under the command of local magistrates in each of the military districts established at the time of the war. It included 8,206 Africans on foot, 800 mounted, and 2,500 in reserve. These forces, less of an invasion force, represent the most consistent element of African contribution to colonial rule. They were "available for the Defence of the colony" according the government report, as they had been available for the vast majority of the formative period of the colony of Natal. ${ }^{190}$

Indigenous military forces were always a key component to the establishment of colonial authority within the British Empire. The colony of Natal was no different in that respect. This chapter has only analysed a select number of incidences from within the colony of Natal. Yet there is clear evidence of a continuing debate which took place within the colony over the use and importance of indigenous forces. This debate largely focused on the divides between Shepstone, the Natal government, and the local European population, which included the Afrikaner sympathizer "One of the People". As has been shown in previous chapters, this was nothing new.

The period of Natal's state formation was a time of great debate and fluidity within the colony. Pressures from all groups within Natal would result in compromises and consolidation from all sides, eventually achieving the outline of a fully functional colonial state. The use of African troops in the defence of the colony, though a practical and largely successful structure in Natal's developing ideas of colonial defence, was an easy target for

189 "His Excellency, the Lieutenant-Governor opened this Second Session of the Eight Council with the Following Speech: Sep. 29, 1879," The Natal News Gazette -Extraordinary, November 6, 1879.

${ }^{190}$ The Natal Government Gazette, November 25, 1879. 
dissenters, reformers, and exceptionalists who were eager and sometimes overzealous in their suggestions for alterations. They can be seen in Stainbank, "One of the People”, and Robson for the volunteers, Dartnell, Currey, and Miles for the mounted police, or even Constable Budaza, alias "Witboy". All of these individuals challenged the established systems and attempted to incorporate their own concepts of security within Natal. For African troops, despite plans from the likes of Pine and Palmer, it was Theophilus Shepstone who defined their use within the colony of Natal.

What does this tell us about the role of Africans in the defensive evolution of the colony of Natal? It reveals that there was clear indigenous involvement in the security of the colony. Such participation not only advances the theory of a type of militarization of society that took place in Natal during this period but also provides a viable platform for incorporating African agency into the administration and creation of Natal as a colonial state. The indigenous African forces of the colony of Natal remained largely associated with British administration and its treatment of other Africans. Nonetheless, these African military units continued to prove again and again their presence, numbers, and capabilities were a key component in the defence of the colony and the colonial structures that were established during the formative years of the colony of Natal. 


\section{Chapter Seven: Conclusion}

Shepstone's 1892 vision of a peaceful Natal over its "forty six years of existence" could, on the surface, be seen as a legitimate claim. Even the Anglo-Zulu War, despite fears of a Zulu invasion after the disaster at Isandlwana, did not bring a major offensive or open conflict into the hills of Natal. Peace, however, is not always the measurement of success, or righteousness, when examining the history of the British Empire. ${ }^{1}$ The trope of "Pax Britannica" and its use as a foundation for law and order within the British Empire is evidence enough of such contradictions. As historians, we use such events as wars and rebellions as a marker to indicate how a society evolves during its formation. This is why few historians have attempted to look exclusively at this formative period in Natal, and instead focus on the aftermath of the Anglo-Zulu War and the conflicts which permeated South Africa as a whole during the build-up to the South African Wars. Although Natal was hardly unique in the context of the emerging British Empire, its history did allow it to have a diverse perspective on the development of colonial rule in Southern Africa during the nineteenth century. The situation on the ground provide major case studies that illustrate a colonial state coming to grips with multiple social, political, racial, and economic problems. The relationships between white and black, European and African, whether beneficial, destructive, or benign, remained intrinsic to Natal's formation as a colonial state.

To claim that the making of Natal was defined solely by the military and police organization which precipitated the formative period of the colony would be overly simplistic. The impact of these institutions, however, cannot be dismissed. The relationships which developed between European, Afrikaner, and African military and police institutions

\footnotetext{
${ }^{1}$ Though some historians have continued to profess the underlying benefits of empire beyond other human costs. See Niall Ferguson, Empire: The Rise and Demise of the British World Order and the Lessons for Global Power (London: Basic Books, 2004).
} 
were indicative of a developing state attempting to come to grips with the problems of security, stability, and safety within the colonial period. Whether autonomous from the colonial government, or with its support, these institutions filled a void which was seen as necessary for the safety and security of the colony. Though the volunteer systems were either impractical or unnecessary, they provided a sense of security and community for the colonists who took part in them. Though the police institutions, both white and black, were either avenues for advancement within colonial society, or simply a means to maintain agency in the expanding scope of British rule, they continued to represent an important pillar in colonial order for the entirety of this formative period. And though the African military units used by Shepstone and the magistracy were rooted in a combination of a shortage of manpower and the perceived "martial race" characteristics of Natal's indigenous inhabitants, their participation in the major events of the colony illustrates the key role of the African in Natal's rise as a colonial entity. Such participation also advances the theory of a type of militarization of society that took place in Natal during this period and provides a viable platform for incorporating African agency into the administration and creation of Natal as a colonial state. Moreover, the multifaceted approach to colonial rule utilized in this dissertation highlights the hybridized makeup of Natal's defensive institutions.

The foundations for future military and police actions were forged during this seminal period. The volunteers would continue to hold on to their military tradition which stemmed from the Langalibalele incident and Anglo-Zulu War. Their regimental histories clearly show that the volunteers would endure (or possibly linger) into the twentieth century, taking part in the First and Second World War, and created veterans' associations which continue to this day. The Royal Carbineer Association still has an active, if diminished, presence in Natal, where they continue to hold meetings and organized events. The memory of their actions during the Anglo-Zulu War have reached an almost mythical level, though this remains a 
common trend in the popular history of the Anglo- Zulu War, as has been commented on by Jeff Guy. ${ }^{2}$ Little reference in these regimental histories was made to the Natal Carbineer's part in the brutal suppression of the Bambatha Rebellion in 1906, with a regimental history written in 1945 simply stating the regiment was "in the thick of things taking their full share of the hard work and fighting till the suppression of the trouble."'3 No reference is made to the killings at Mome Gorge where 600 of Bambatha's followers, given no chance to surrender, were massacred by the segments of the volunteers. ${ }^{4}$ Nonetheless, there remains a strong memory of the Carbineers and volunteers within the colony, and a Carbineer Street still cuts through central Pietermaritzburg, though somewhat off the main road. ${ }^{5}$

The Natal Mounted Police did not fare as well as their volunteer counterparts. Though they received some acclaim in their escorting of the Prince Imperial's mother to the site of her son's death following the Anglo-Zulu War, their effectiveness as a police force declined over the ensuing years. By 1892, the force was declared a failure by a magistrate's commission though it would retain a small force until its amalgamation with the rest of Natal's police branches in 1894. The unit would act as part of said police force well into the next decade, and along with the volunteers would take part in the Bambatha Rebellion. Like the rest of Southern Africa's police forces, they were absorbed into the South African Constabulary under the Union Government in 1910. Major Dartnell would eventually become

\footnotetext{
${ }^{2}$ Guy particularly criticized how the war has been used as a misrepresentation of history in an effort to illustrate some admirable aspects of British and Zulu character during the war. See Jeff Guy, "Battling with Banality," Journal of Natal and Zulu History 18, no. 1 (October 12, 1998).

${ }^{3}$ Hurst, Short History of the Volunteer Regiments of Natal and East Griqualand: Past and Present, 27.

${ }^{4}$ For more on the rebellion, see Marks, Reluctant Rebellion; Guy, Remembering the Rebellion.

${ }^{5}$ The one block side street (or alley) could easily be missed as it runs parallel with Langalibalele and Jabu Ndlovu Street two blocks south of Pietermaritzburg City Hall on Chief Albert Luthuli Street. However, it has yet to be changed in the wake of street renaming that has taken place in many cities in KwaZulu-Natal.
} 
Major General Dartnell, commanding Natal's police forces for thirty years until becoming the Honourable Colonel in Chief of the Colonial Forces of Natal. ${ }^{6}$

The African police would continue to act within the administrative system of the British colonial government of Natal. Africans continued to be the majority of police in the rural regions for the remainder of the nineteenth century. The Natal Native Police would also act as the principle inspiration for the Zululand Police. Formed in 1883, the Zululand Police oversaw the implementation of law and order for decades following the Anglo-Zulu War. They also took part in the Bambatha Rebellion, and like their predecessors under Shepstone, were instrumental in the putting down of their fellow Africans. Unlike many African police during the early colonial period, however, there seemed to be a greater system of regulation which was not a hallmark of the formative period of the colony. The Zululand Police continued the tradition of the British government using Africans as a cheaper alternative to white manpower. It also cultivated the advancement of these police as part of the "civilizing mission" directed toward the colony's African population. African troops and levies would also be called upon in this same manner for the ensuing decades of the nineteenth and early twentieth century, and even form a Natal Native Horse regiment during the Bambatha Rebellion, continuing the tradition of African troops being used to put down other Africans in rebellion. ${ }^{7}$

Though some work continues to be done on these aspects of Natal's defensive institutions, there is a gap in the historiography regarding the nature of these systems within

\footnotetext{
${ }^{6}$ Dartnell, in his own right, is a figure that deserves greater attention, especially his early work within Natal. Though easily dismissed as a typical British military official during the colonial period, there is space for a more nuanced examination of his contribution to Natal's colonial defensive institutions within the literature.

${ }^{7}$ Paul Thompson has addressed this issue in a recent paper, looking at the topic of African loyalty to the British versus the Zulu king during the rebellion, leading to more nuances questions on collaboration and resistance, See P. S Thompson, “'Loyalty's Fair Reward': The Natal Native Horse in the Zulu Rebellion of 1906” (Unpublished paper presented at the ASA 2013, Panel: The Zulu Kingdom, Guns and Security of the Colonial State, November 23, 2013); Paul Thompson, “'Loyalty's Fair Reward': The Natal Native Horse in the Zulu Rebellion of 1906," South African Historical Journal 66, no. 4 (2014): 656-76.
} 
Natal's history. This dissertation has contributed to an understanding of Natal's defensive institutions, but more work is needed to better understand the role of these institutions in the overall history of Natal, South Africa, and the British Empire. Larger questions of race, colonial policy, resistance, and collaboration continue to be widely debated within the historiography. Even with decolonization, the architects of African independence, to an extent, are still attempting to define the greater nuances of these questions, especially collaboration and resistance. Many African leaders, freedom fighters, or everyday peoples were not exclusively part of secondary resistance institutions, collaboration, or simply "stooges" working within the existing colonial systems. All were part of these African states and systems' rise to power and eventual independence. Resistors were not less enlightened than their collaborator counterparts, but the idea of the "romantic reactionaries" to colonial rule discussed by Robinson and Gallagher in many ways proved the foundation for future nationalist narratives. Because of the positive and negative associations given by nationalist narratives to resistance and collaboration, it has only been recently that historians have begun to truly examine the growing complexities between these two identifiers. ${ }^{8}$ The very fact that Africa was not conquered and colonial rule was not enforced by Europeans alone gives a clear indication of the greater complexities that go with defining collaboration and resistance. This dissertation is part of a growing body of work that no longer asks the question of "who were collaborators and who were resistors" but instead asks the more evocative question of "what were the roles of Africans in colonialism".

This dissertation is also part of an emerging segment of the field attempting to define the colony of Natal and Shepstone's influence within a greater Southern African context.

\footnotetext{
${ }^{8}$ Jacob Dlamini's recent book on "Comrade September", a member of the ANC and its military wing, MK, is at the cusp of this new wave of examination attempting a more nuanced way of developing an understanding of collaboration in the colonial setting. Jacob Dlamini, Askari: A Story of Collaboration and Betrayal in the AntiApartheid Struggle (Sunnyside, South Africa: Jacana Media, 2015).
} 
Recent scholarship by Jeff Guy and Thomas McClendon cast new light on Shepstone and Natal during the formative period. There has been somewhat a backlash growing against the work of Jeff Guy, particularly an upcoming review by Norman Etherington in the Journal of New Zealand History which challenges several key components of Guys argument, particular the importance of factors beyond Natal. ${ }^{9}$ Another is the upcoming article on "decentering Shepstone" by Jeremy Martens, who has described Guy's work as “a revisionist piece... designed to provoke debate and disagreement". Some will take issue with it in their own work and incite debate on the topic of Shepstone and his place in Natal history. ${ }^{10}$ Such debate is good for the field, as it forces those who support each side to delve deeper into the archives and re-examine assumed premises of Natal's history. ${ }^{11}$ Hlonipha Mokoena's unpublished work on African police in Natal in the late nineteenth and early twentieth century also illustrates the growing importance of looking at Natal from a new perspective. Perhaps most encouraging, a new crop of recent PhDs and students have taken up the topic of Shepstone, Natal, and the people of these regions in new and exciting ways. ${ }^{12}$ Such new research, along with this dissertation, contributes to this growing component of African and British imperial history. Natal, after being long overlooked, is finally beginning to gain the attention it deserves.

It is perhaps most fitting that Natal was one of the only states which did not receive the honour of hosting one of South Africa's three capitals after the Act of Union in 1910.

\footnotetext{
${ }^{9} \mathrm{My}$ thanks to Dr. Etherington for allowing me to read this review before publication. ${ }^{10}$ Jeremy Martens, "Decentring Shepstone: The eastern Cape frontier and the establishment of native administration in Natal, 1842-1849”, forthcoming in South African Historical Journal (2015).

${ }^{11}$ Sadly, Jeff Guy's death in December 2014 has left a void in the field. But new scholarship is quick to try and fill his place, illustrated by a memorial panel that will be hosted by $25^{\text {th }}$ Conference of the Southern African Historical Society (SAHS) in July 2015 at Stellenbosch, South Africa. Chaired by Keith Breckenridge, the panel will be devoted to new work inspired by Dr. Guy.

12 Examples include T.J. Tallie, "Racialised Masculinity and the Limits of Settlement: John Dunn and Natal, 1879-1883," Journal of Natal and Zulu History 30 (2012); Jochen Arndt, "The Great Bifurcation: Missionary Linguistics and the Emergence of 'Xhosa' and 'Zulu' as Ethno- Linguistic Identities, 1820-1870" (Unpublished paper presented at the ASA 2014, Panel: Identity and Violence, 2014).
} 
Practically, Natal was simply a victim of mathematics, claiming the smallest population between the Cape Colony, Orange Free State, and South African Republic. Its omission, however, is a telling example of Natal's place in the consciousness and history of South Africa. As has been shown, despite being close neighbours to three nations the British Empire waged war with during the nineteenth century (the Afrikaner Republics and the Zulu Kingdom), Natal forged itself into a viable colonial state with its own systems of administration and defence that ensured its survival. These defensive institutions contribute a small, but nevertheless important part of the underlying question of this topic: Natal's rise as a colonial state. Previous scholarship has tended to view the history of Natal as part of the backdrop to the larger story of South Africa. This placement in South African history was far from a foregone conclusion. At its core, the response and development of these defensive institutions within the colony shows the fluid and contentious nature of state formation within colonial Natal, and the British Empire as a whole. In essence, the fate of the colony of Natal, with its incorporation into the Union of South Africa in 1910, should not be regarded as inevitable or preordained. Instead, Natal built itself up as a colonial state to illustrate its place as a viable colony within the British Empire. The defensive institutions it created were but one layer of a foundation of colonial authority which precipitated the colonial period in Southern Africa. The making of Natal, in the scope of South African history, was a continuing process.

More importantly, these defensive institutions reveal a vital component in understanding the nature of colonial rule in Natal. The debates over these systems of defence and their continued evolution during the formative period highlights a massive disconnect that existed between many segments of the colonial population. In many cases, settlers, police, volunteers, and even African troops were unsure of their role within colonial society. Despite all measures and assurances of "peace", anxiety was the true state of existence in 
nineteenth century Natal. These defensive institutions were established for the sake of protection against dangers, whether internal or external. With such concerns, it is no surprise that the colonial state and its population were constantly attempting to improve or change these systems for the perceived benefit of the colony as a whole, whether necessary or not. When the editor of the Natal Witness feared the creation of "a Pretorian guard of savages", he ignored the success of those like Budaza. When blame was cast for the Langalibalele Incident, the volunteers were raised up as martyrs and the Africans were singles out for tardiness, despite the Africans being the primary force that put down the rebellion. These attacks and condemnations of the defensive institutions were not only the product of racism from the settler community, but were the product of fear, anxiety, and misunderstanding. When colonists were attempting to "Make Natal", they first and foremost wanted a safe Natal. And despite all of their apprehension, it remained somewhat safe and peaceful, thanks to the combined efforts of European and African, military and police, rich and poor, and finally, wanted and unwanted. Combined, these defensive institutions were critical in the making of colonial Natal. 


\section{Appendix:}

Map 1: Natal and Neighbouring States c. 1875 (CO 879/3)

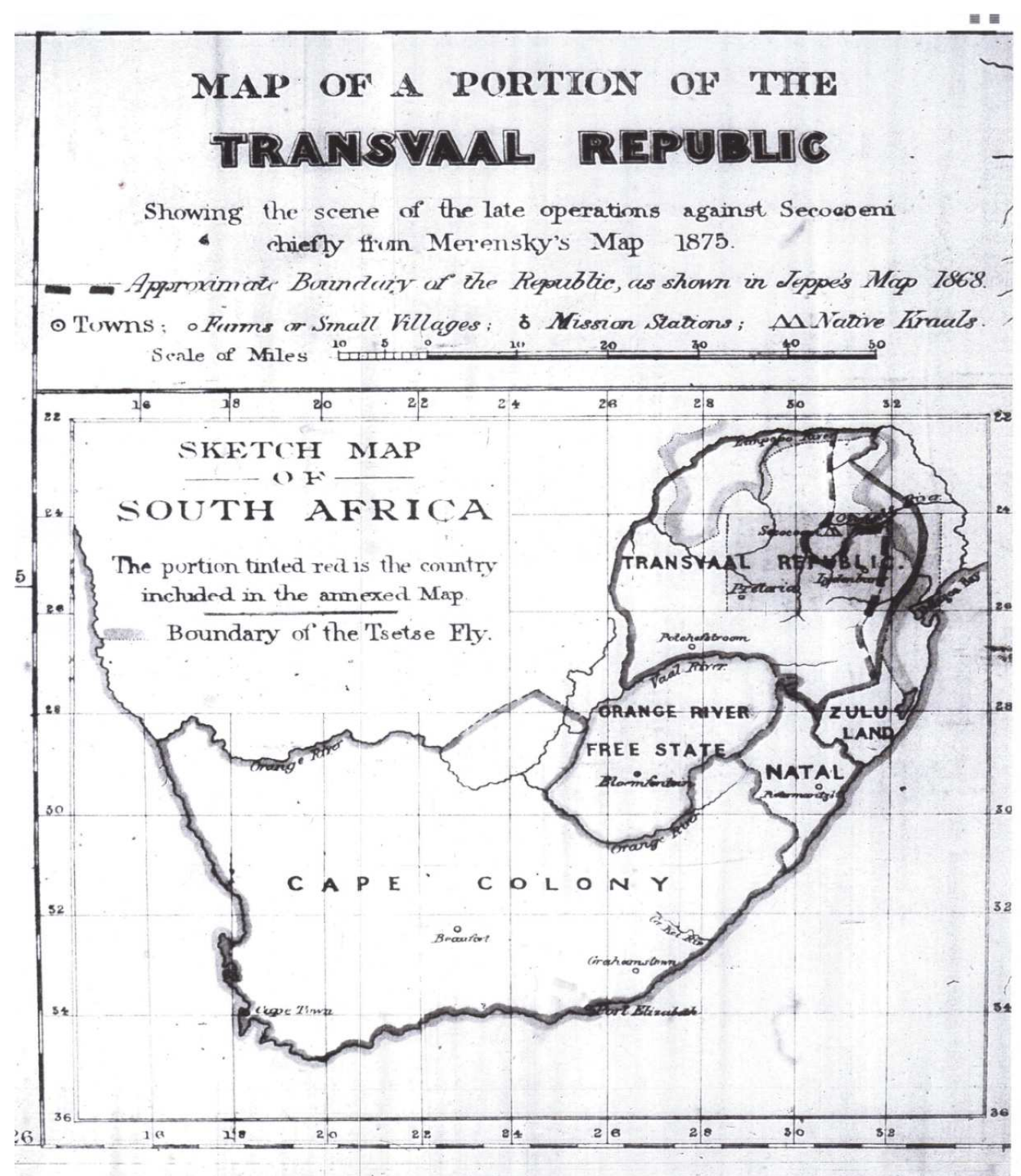


Map 2: Natal, c. 1860

Source: Franco Frescura Collection (Accessed from:

http://www.sahistory.org.za/content/colony-natal-and-part-colony-cape-1860 )

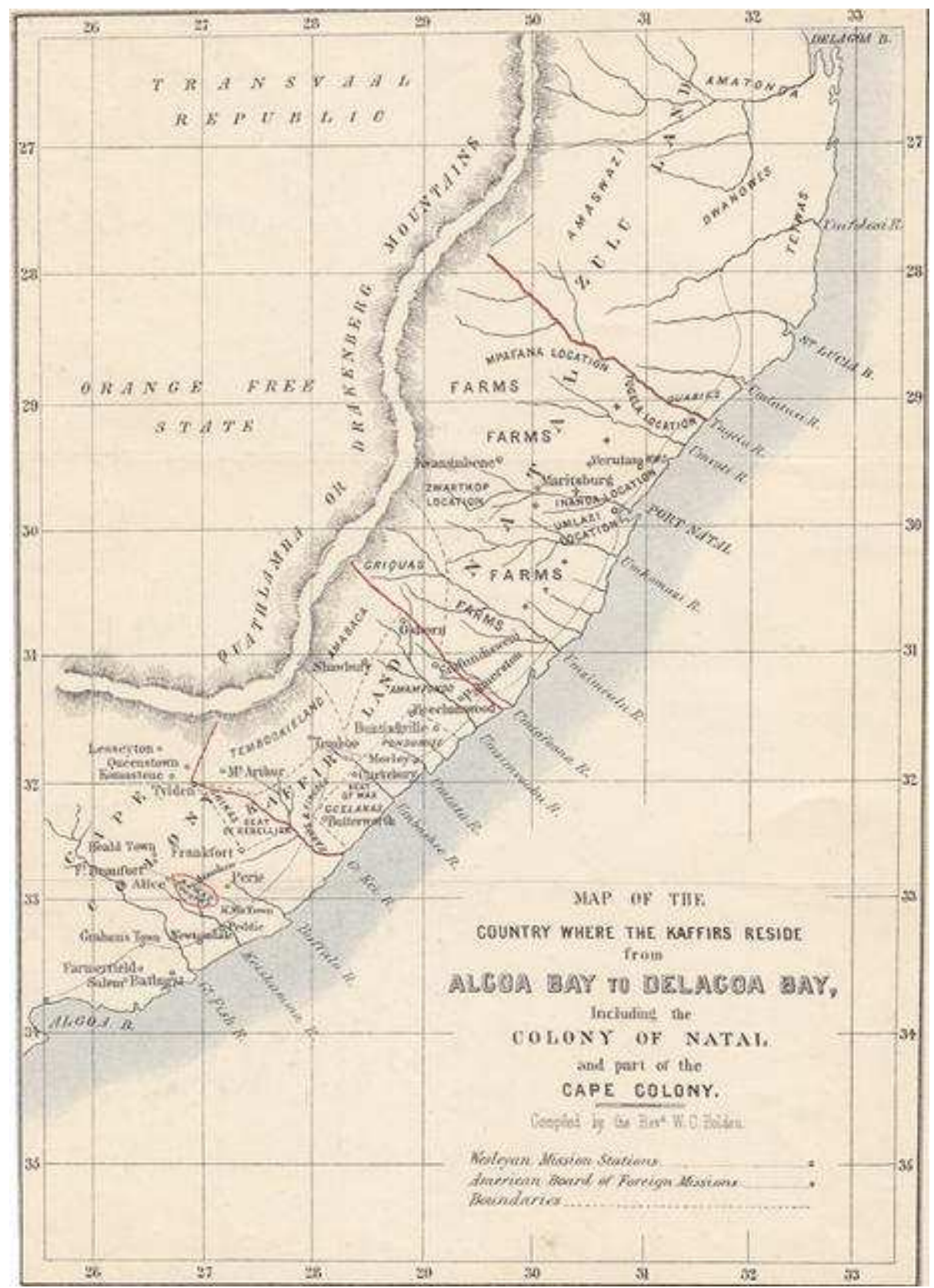




\section{Bibliography}

\section{Archives}

AGO Attorney General's Office of the Colony of Natal (Pietermaritzburg Archives)

CSO Colonial Secretary's Office of the Colony of Natal (Pietermaritzburg Archives)

CO Colonial Office Reports (UK National Archives at Kew)

GH Government House, Colony of Natal (Pietermaritzburg Archives)

KCM Campbell Manuscript Collection (Killie Campbell Africana Library)

NCP Natal Colonial Publications (Pietermaritzburg Archives)

RSC Registrar, Supreme Court, Pietermaritzburg (Pietermaritzburg Archives)

\section{Newspapers}

The Natal Government Gazette (Pietermaritzburg)

The Natal Mercury (Durban)

The Natal Witness (Pietermaritzburg)

Time of Natal (Durban)

\section{Published Primary Sources}

Bird, John. Annals of Natal:1495-1845, Vol. 1. Pietermaritzburg: P. Davis \& Sons, 1888. Annals of Natal:1495 to 1845, Vol. 2. Pietermaritzburg: P. Davis \& Sons, 1888.

British Colonial Office. Natal Blue Books. 1850-1883.

British Parliamentary Papers. Correspondence Relative to the Establishment of the Settlement of Natal and the Recent Rebellion of the Boers. London, 1850.

- Correspondence Related to the Establishment of the Settlement of Natal, London, 1851.

- Further Correspondence Related to the Settlement of Natal. London, 1851.

- Papers Related to the Late Kafir Outbreak in Natal. London, 1874.

—. Reports from Committees: Army (India and the Colonies). London, 1867. 
Cadiz, Charles Fitzwilliam. Natal Ordinances, Laws, and Proclamations: Compiled and Edited Under the Authority and with the Sanction of His Excellency the Lieutenant Govenor and the Honorable the Legislative Council. Pietermaritzburg [S. Africa]: WM Watson Government Printers, 1891.

Clarke, W. J. The N.M.P.: A Record of the Services of the Natal Mounted Police. Pietermaritzburg: Calvert, 1893.

Colenso, John William. Ten Weeks in Natal: A Journal of a First Tour of Visitation Among the Colonists and Zulu Kafirs of Natal. London: Macmillan \& Company, 1855.

Emigration to Natal, and Conditions of Government Land Grants: With Full Description of the Colony and Its Industries. London: Jarrold \& Sons, 1876.

Eybers, G.W. Select Constitutional Documents Illustrating South African History, 17951910. London: George Routledge \& Sons, 1918.

Holden, William C. History of the Colony of Natal, South Africa. London: Alexander Heylin, 1855.

Ingram, Joseph Forsyth. The Colony of Natal: An Official Illustrated Handbook and Railway Guide. London: Sir Joseph Causton and Sons, 1895.

Lucas, Thomas J. Camp Life and Sport in South Africa, Experiences of Kaffir Warfare with the Cape Mounted Rifles. London: Chapman and Hall, 1878.

Mann, Robert James. The Colony of Natal: An Account of the Characteristics and Capabilities of This British Dependency. London: Jarrold and Sons, 1859.

Moodie, Duncan Campbell Francis. The History of the Battles and Adventures of the British, the Boers, and the Zulus, \& C. in Southern Africa: From the Time of Pharaoh Necho to 1880. Cape Town: Murray \& St. Leger, 1888.

Moodie, William James Dunbar. Ordinances, Proclamations Relating to the Colony of Natal, 1836-1855, with Notes of Reference. Pietermaritzburg: May and Davis, 1866.

The Natal Almanac and Yearly Register. Pietermaritzburg: P. Davis, 1867.

The Natal Carbineers: The History of the Regiment from Its Foundation, 15th January 1855 to 30th June 1911. Pietermaritzburg: P. Davis, 1912.

Natal Law Reports: Supreme Court. Pietermaritzburg: Munro, 1902.

Natal Police Force: Revised Rules and Regulations. Pietermaritzburg: P. Davis \& Sons, 1906.

The Natal's Who's Who Publishing Company. The Natal Who's Who: An Illustrated Biographic Sketch Book of Natalians. Durban, South Africa: Robinson \& Co, 1906. 
Russell, George. The History of Old Durban and Reminiscense of an Emigrant of 1850. Durban, South Africa: P. Davis \& Sons, 1908.

Stainbank, H. E. Coffee in Natal: Its Culture and Preparation. London: Edward Stanford, 1874.

Webb, C. De B., and J. B. Wright, eds. The James Stuart Archive Vol. 5: Of Recorded Oral Evidence Relating to the History of the Zulu and Neighboring Peoples.

Pietermaritzburg: University Of KwaZulu-Natal Press, 2001.

Webb, Colin de B, J. A Verbeek, Mary Nathanson, Elaine Peel, and Colin de B Webb. Webb's Guide to the Official Records of the Colony of Natal. Pietermaritzburg: University of Natal, 1984.

\section{Published Secondary Sources}

\section{Books}

Adhikari, Mohamed. Not White Enough, Not Black Enough: Racial Identity in the South African Coloured Community. Athens, Ohio: Ohio University Press, 2009.

Anderson, David, and David Killingray, eds. Policing the Empire: Government, Authority, and Control, 1830-1940. Manchester, UK: Manchester University Press, 1991.

Arnold, David. Police Power and Colonial Rule: Madras 1859-1947. Delhi: Oxford University Press, 1986.

Bayly, Christopher Alan. Empire and Information: Intelligence Gathering and Social Communication in India, 1780-1870. Cambridge University Press, 2000.

Beckett, Ian F. W., ed. Citizen Soldiers and the British Empire, 1837-1902. London: Pickering \& Chatto, 2012.

Belich, James. Replenishing the Earth: The Settler Revolution and the Rise of the AngloWorld, 1783-1939. Oxford: Oxford University Press, 2009.

Boemeke, Manfred F., Roger Chickering, and Stig Förster, eds. Anticipating Total War: The German and American Experiences, 1871-1914. Cambridge: Cambridge University Press, 1999.

Bolt, Christine. Victorian Attitudes to Race. London: Routledge and K. Paul, 1971.

Braybon, Gail, ed. Evidence, History, and the Great War: Historians and the Impact of 191418. New York: Berghahn Books, 2003.

Briggs, Asa. Victorian Cities. London: Odhams Press, 1963. 
Brooks, Edgar H., and C. De B. Webb. A History of Natal. Pietermaritzburg: University of Natal Press, 1965.

Burton, Antoinette. At the Heart of the Empire: Indians and the Colonial Encounter in LateVictorian Britain. Berkeley: University of California Press, 1998.

Colley, Linda. Britons: Forging the Nation, 1707-1837. New Haven: Yale University Press, 1992.

Cooper, Frederick, and Ann Laura Stoler. Tensions of Empire: Colonial Cultures in a Bourgeois World. Berkeley: University of California Press, 1997.

Cox, George William. The Life of John William Colenso, D.D. Volume II. London: W. Ridgeway, 1888.

Cunningham, Hugh. The Volunteer Force: A Social and Political History, 1859-1908. London: Croom Helm, 1975.

Currey, R.N. Letters and Other Writings of a Natal Sheriff: Thomas Phipson, 1815-1876. Cape Town: Oxford University Press, 1968.

Davidson, Basil. Africa in History. Revised edition. New York: Touchstone Books, 1995.

Dlamini, Jacob. Askari: A Story of Collaboration and Betrayal in the Anti-Apartheid Struggle. Sunnyside, South Africa: Jacana Media, 2015.

Duminy, Andrew, and Bill Guest, eds. Natal and Zululand from Earliest Times to 1910: A New History. University of Natal Press, 1990.

Elbourne, Elizabeth. Blood Ground: Colonialism, Missions, and the Contest for Christianity in the Cape Colony and Britain, 1799-1853. Montreal: McGill-Queen's University Press, 2002.

Etherington, Norman. Preachers, Peasants and Politics in Southeast Africa, 1835-1880: African Christian Communities in Natal, Pondoland and Zululand. Royal Historical Society Studies in History Series, no. 12. London: Royal Historical Society, 1978.

- The Great Treks: The Transformation of Southern Africa, 1815-1854. Turning Points. Harlow, England; New York: Longman, 2001.

Ferguson, Niall. Empire: The Rise and Demise of the British World Order and the Lessons for Global Power. London: Basic Books, 2004.

Frevert, Ute. A Nation in Barracks: Modern Germany, Military Conscription and Civil Society. First Edition edition. Oxford; New York: Bloomsbury Academic, 2004.

Galbraith, John S. Reluctant Empire: British Policy in the South African Frontier, 1834-1854. Westport, CT: Greenwood Press, 1978. 
Gee, Austin. The British Volunteer Movement 1794-1814. Oxford: Oxford University Press, 2003.

Gewald, Jan-Bart. Herero Heroes: Socio-Political History Of Herero Of Namibia,. Athens, Ohio: Ohio University Press, 1999.

Gramsci, Antonio. Selections from the Prison Notebooks. Edited by Quintin Hoare and Geoffrey Nowell Smith. New York: International Publishers, 1971.

Guest, Bill, and John M. Sellers. Enterprise and Exploitation in a Victorian Colony: Aspects of the Economic and Social History of Colonial Natal. University of Natal Press, 1985.

Guy, Jeff. Remembering the Rebellion: The Zulu Uprising of 1906. Scottsville, South Africa: University of KwaZulu-Natal Press, 2006.

- The Destruction of the Zulu Kingdom: The Civil War in Zululand, 1879-1884. Pietermaritzburg [S. Africa]: University of Natal Press, 1994.

- The Heretic: A Study of the Life of John William Colenso, 1814-1883. Johannesburg Pietermaritzburg: Ravan Press ; University of Natal Press, 1983.

- Theophilus Shepstone and the Forging of Natal: African Autonomy and Settler Colonialism in the Making of Traditional Authority. Scottsville, South Africa: University of KwaZulu-Natal Press, 2013.

—. The View Across the River: Harriette Colenso and the Zulu Struggle Against Imperialism. Reconsiderations in Southern African History. Charlottesville, Va: University Press of Virginia, 2002.

Hall, Catherine. Civilising Subjects: Colony and Metropole in the English Imagination, 18301867. Chicago: University of Chicago Press, 2002.

Hamilton, Carolyn. Terrific Majesty: The Powers of Shaka Zulu and the Limits of Historical Invention. Harvard University Press, 1998.

- , ed. The Mfecane Aftermath: Reconstructive Debates in Southern African History. 1st ed. Witwatersrand University Press, 1995.

Harris, Andrew T. Policing the City: Crime and Legal Authority in London, 1780-1840. Columbus: Ohio State University Press, 2004.

Hattersley, Alan Frederick. Carbineer; the History of the Royal Natal Carbineers. Aldershot,: Gale and Polden, 1950.

- Portrait of a Colony: The Story of Natal,. Cambridge, UK: University Press, 1940.

- The British Settlement of Natal; A Study in Imperial Migration. Cambridge, UK: University Press, 1950. 
—. The Natalians; Further Annals of Natal. Pietermaritzburg,: Shuter \& Shooter, 1940.

Henderson, W. P. M. Durban: Fifty Years' Municipal History. Durban, South Africa:

Robinson, 1904.

_. Durban: Fifty Years' Municipal History. Durban, South Africa: Robinson, 1904.

Holt, H. P. The Mounted Police of Natal. London : J. Murray, 1913.

Hopkins, Anthony G. An Economic History of West Africa. New York: Columbia University Press, 1973.

Hull, Isabel V. Absolute Destruction: Military Culture and the Practices of War in Imperial Germany. Cornell University Press, 2006.

Hurst, Godfrey T. Short History of the Volunteer Regiments of Natal and East Griqualand: Past and Present. Durban, South Africa: Know Publishing Company, 1945.

Jeffries, Sir Charles. The Colonial Police. London: Max Parrish, 1952.

Joyce, Patrick. The Rule of Freedom: Liberalism and the Modern City. London: Verso, 2003.

Kiernan, V.G. Colonial Empires and Armies 1815-1960. Gloucestershire, UK: Sutton Publishing, 1998.

Killingray, David, and Anthony Clayton. Khaki and Blue: Military and Police in British Colonial Africa. Ohio University Center for International Studies Monographs in International Studies, Africa Series. Athens, Ohio: Ohio University, 1989.

Krüger, Christine G, and Sonja Levsen, eds. War Volunteering in Modern Times: From the French Revolution to the Second World War. Houndmills, Basingstoke, Hampshire; New York, NY: Palgrave Macmillan, 2011.

Laband, John, P. S Thompson, and Sheila Henderson. The Buffalo Border, 1879: The AngloZulu War in Northern Natal. Durban: Dept. of History, University of Natal, 1983.

Lambert, David, and Alan Lester, eds. Colonial Lives Across the British Empire: Imperial Careering in the Long Nineteenth Century. Cambridge University Press, 2010.

Lambert, John. Betrayed Trust: Africans and the State in Colonial Natal. Scottsville, UZA: University of Natal Press, 1995.

Lees, Andrew. Cities and the Making of Modern Europe, 1750-1914. New Approaches to European History. Cambridge, UK; New York: Cambridge University Press, 2007.

Liang, Hsi-huey. The Rise of Modern Police and the European State System from Metternich to the Second World War. Cambridge [England]; New York: Cambridge University Press, 1992. 
Low, D. A. Fabrication of Empire: The British and the Uganda Kingdoms, 1890-1902. Cambridge, UK ; New York: Cambridge University Press, 2009.

Lunt, James. Imperial Sunset: Frontier Soldering in the 20th Century. London: Macdonald, 1981.

Mahoney, Michael R. The Other Zulus: The Spread of Zulu Ethnicity in Colonial South Africa. Durham, NC: Duke University Press Books, 2012.

Mamdani, Mahmood. Citizen and Subject: Contemporary Africa and the Legacy of Late Colonialism. Princeton, N.J: Princeton University Press, 1996.

Marks, Shula. Reluctant Rebellion: The 1906-8 Disturbances in Natal. Oxford Studies in African Affairs. Oxford: Clarendon P, 1970.

Maylam, Paul, and Iain Edwards. The People's City: African Life in Twentieth-Century Durban. Pietermaritzburg: University of Natal Press, 1996.

McClendon, Thomas V. White Chief, Black Lords: Shepstone and the Colonial State in Natal, South Africa, 1845-1878. Rochester Studies in African History and the Diaspora, v. 46. Rochester, NY: University of Rochester Press, 2010.

Miller, Stephen M. Volunteers on the Veld: Britain's Citizen-Soldiers and the South African War, 1899-1902. Norman: University of Oklahoma Press, 2007.

Mokoena, Hlonipha. Mugema Fuze: The Making of a Kholwa Intellectual. Scottsville, UZA: University of KwaZulu-Natal Press, 2011.

Morrell, Robert. From Boys to Gentlemen: Settler Masculinity in Colonial Natal, 1880-1920. Pretoria: Unisa Press, 2001.

Morris, Donald R. The Washing of the Spears: A History of the Rise of the Zulu Nation Under Shaka and Its Fall in the Zulu War of 1879. New York: Da Capo Press, 1998.

Myerly, Scott. British Military Spectacle: From the Napoleonic Wars through the Crimea. Cambridge, MA: Harvard University Press, 1996.

Nightingale, Carl H. Segregation: A Global History of Divided Cities. Chicago: University Of Chicago Press, 2012.

Nordbruch, Claus. The European volunteers in the Anglo-Boer War 1899-1902. Pretoria: Auslieferung durch Tiegerpoort Versamelaars, 1999.

Omer-Cooper, J. D. The Zulu Aftermath: A Nineteenth-Century Revolution in Bantu Africa. Evanston, Ill: Northwestern University Press, 1966.

Palmer, Stanley H. Police and Protest in England and Ireland, 1780-1850. Cambridge: Cambridge University Press, 1988. 
Parsons, Timothy. Social Implications of Colonial Military Service in the King's African Rifles, 1902-1964. The African Rank-and-File. Portsmouth, NH: Heinemann, 1999.

Pearse, R. O, J. Clark, P.R. Barnes, and G. Tatham, eds. Langalibalele and the Natal Carbineers: The Story of the Langalibalele Rebellion, 1873. Ladysmith: Ladysmith Historical Society, 1973.

Penn, Nigel. The Forgotten Frontier: Colonist and Khoe-San on the Cape's Northern Frontier in the Eighteenth Century. Athens, Ohio: Ohio University Press, 2005.

Price, Richard. Making Empire: Colonial Encounters and the Creation of Imperial Rule in Nineteenth-Century Africa. Cambridge University Press, 2008.

Richards, Jonathan. The Secret War: A History of Queensland's Native Police. St. Lucia, Queensland: University of Queensland Press, 2008.

Robinson, Ronald, John Gallagher, and Alice Denny. Africa and the Victorians: The Official Mind of Imperialism. London: Macmillan, 1961.

Saunders, Christopher. The Making of the South African Past: Major Historians on Race and Class. Totowa, N.J: Rowman \& Littlefield Publishers, 1988.

Schneer, Jonathan. London 1900: The Imperial Metropolis. New Haven: Yale University Press, 1999.

Senior, Hereward. The Last Invasion of Canada: The Fenian Raids, 1866-1870. Toronto: Dundurn, 1991.

Spencer, Shelagh O'Byrne. British Settlers in Natal 1824-1857: A Biographical Register: Gadney-Guy. Pietermaritzburg: University of Natal Press, 2001.

Stapleton, Timothy Joseph. African Police and Soldiers in Colonial Zimbabwe, 1923-80. Rochester, NY: University of Rochester Press, 2011.

- A Military History of South Africa: From the Dutch-Khoi Wars to the End of Apartheid. Santa Barbara, Calif.: Praeger, 2010.

—. Faku: Rulership and Colonialism in the Mpondo Kingdom (c. 1780-1867). Waterloo, Ont.: Wilfrid Laurier Univ. Press, 2001.

Steinhart, Edward I. Conflict and Collaboration: The Kingdoms of Western Uganda, 18901907. Princeton, N.J: Princeton University Press, 1977.

Storey, William Kelleher. Guns, Race, and Power in Colonial South Africa. Cambridge; New York: Cambridge University Press, 2012.

Streets, Heather. Martial Races: The Military, Race and Masculinity in British Imperial Culture, 1857-1914. Manchester, UK: Manchester University Press, 2011. 
Sullivan, J. R. The Native Policy of Sir Theophilus Shepstone. Johannesburg: Walker \& Snashall, 1928.

Taylor, David. Policing the Victorian Town: The Development of the Police in Middlesbrough C. 1840-1914. New York, N.Y.: Palgrave Macmillan, 2002.

Thompson, Leonard. A History of South Africa. 3rd edition. New Haven, CT: Yale University Press, 2001.

Thompson, Paul. “'Loyalty's Fair Reward': The Natal Native Horse in the Zulu Rebellion of 1906.” South African Historical Journal 66, no. 4 (2014): 656-76.

Thompson, P. S. Black Soldiers of the Queen: The Natal Native Contingent in the Anglo-Zulu War. Tuscaloosa: University of Alabama Press, 2006.

Uys, C.J. In the Era of Shepstone: Being a Study of British Expansion in South Africa (18421877. Lovedale, South Africa: Lovedale Press, 1933.

Verhey, Jeffrey. The Spirit of 1914: Militarism, Myth and Mobilization in Germany. Cambridge; New York: Cambridge University Press, 2000.

Welsh, David. The Roots of Segregation; Native Policy in Colonial Natal, 1845-1910. Cape Town, New York: Oxford University Press, 1971.

Wesseling, H. L. Imperialism and Colonialism: Essays on the History of European Expansion. Westport, Conn: Praeger, 1997.

Wilson, Edward. Reminiscences of a Frontier Armed \& Mounted Police Officer in South Africa. Grahamstown: C.T. Campbell, 1866.

Wilson, Kathleen, ed. A New Imperial History: Culture, Identity and Modernity in Britain and the Empire, 1660-1840. Cambridge, UK: Cambridge University Press, 2004.

- The Island Race: Englishness, Empire and Gender in the Eighteenth Century. London; New York: Routledge, 2002.

Wilson, Monica, and Leonard Monteath Thompson, eds. The Oxford History of South Africa. Vol. I: South Africa to 1870. New York: Oxford University Press, 1969.

Wood, James. Militia Myths: Ideas of the Canadian Citizen Soldier, 1896-1921. Vancouver: University of Washington Press, 2010.

Wright, Gwendolyn. The Politics of Design in French Colonial Urbanism. Chicago: University of Chicago Press, 1991.

Wylie, Dan. Myth of Iron: Shaka in History. Scottsville, South Africa: University of KwaZulu-Natal Press, 2006.

Young, Crawford. The African Colonial State in Comparative Perspective. New York: Yale University Press, 1994. 
Young, P.J. Boot and Saddle: A Narrative Record of the Cape Regiment, the British Cape Mounted Rifles, the Frontier Armed Mounted Police, and the Colonial Cape Mounted Riflemen. Cape Town: Maskew Miller Limited, 1955.

\section{Articles and Chapters}

Atmore, Anthony, and Peter Sanders. "Sotho Arms and Ammunition in the Nineteenth Century." The Journal of African History 12, no. 04 (1971): 535-44.

Black, Jeremy. "Military Organisations and Military Change in Historical Perspective." The Journal of Military History 62, no. 4 (October 1, 1998): 871-92.

Cobbing, Julian. "The Mfecane as Alibi: Thoughts on Dithakong and Mbolompo." The Journal of African History 29, no. 3 (1988): 487-519.

Etherington, Norman. "The 'Shepstone System' in the Colony of Natal and Beyond the Borders." In Natal and Zululand from Earliest Times to 1910: A New History. Pietermaritzburg [S. Africa]: Univ of Natal Press, 1989.

- "Were There Large States in the Coastal Regions of Southeast Africa before the Rise of the Zulu Kingdom?" History in Africa 31 (January 1, 2004): 157-83.

__. "Why Langalibalele Ran Away.” Journal of Natal and Zulu History 1 (1978): 1-24.

Facey-Crowther, David. "Militiamen and Volunteers: The New Brunswick Militia 17871871." Acadiensis 20, no. 1 (October 1, 1990): 148-73.

Ghosh, Durba. “Another Set of Imperial Turns?” The American Historical Review 117, no. 3 (June 1, 2012): 772-93.

Guy, Jeff. "Battling with Banality." Journal of Natal and Zulu History 18, no. 1 (October 12, 1998). http://www.kznhass-history.net/ojs/index.php/jnzh/article/view/330.

Kennedy, Dane. "Imperial History and Postcolonial Theory." Journal of Imperial and Commonwealth History 24, no. 2 (2001): 131-41.

Kiernan, V.G. "Colonial Africa and Its Armies." In War and Society: A Yearbook of Military History, 20-39. 2. London: Croom Helm, 1977.

Kubicek, Robert. "British Expansion, Empire, and Technological Change." In The Oxford History of the British Empire: Volume III: The Nineteenth Century, edited by Andrew Porter, 247-69. Oxford: Oxford University Press, 2001.

Lynn, John A. "The Evolution of Army Style in the Modern West, 800-2000." The International History Review 18, no. 3 (August 1, 1996): 505-45.

Mackay, Mary. "Captors or Captives? The Australian Native Mounted Police.” In Body Trade: Captivity, Cannibalism, and Colonialism in the Pacific, 47-65. New York: Routledge, 2001. 
Marks, Shula. "The Nguni, the Natalians, and Their History." The Journal of African History 8, no. 03 (1967): 529-40.

McClendon, Thomas. "The Man Who Would Be Inkosi: Civilising Missions in Shepstone's Early Career.” Journal of Southern African Studies 30, no. 2 (June 1, 2004): 339-58.

Ogborn, Miles. "The Power of Speech: Orality, Oaths and Evidence in the British Atlantic World, 1650-1800." Transactions of the Institute of British Geographers 36, no. 1 (January 1, 2011): 109-25.

Omer-Cooper, J. D. "Has the Mfecane a Future? A Response to the Cobbing Critique." Journal of Southern African Studies 19, no. 2 (June 1993): 273-94.

Parsons, Timothy. "African Participation in the British Empire." In Black Experience and the Empire, edited by Philip D. Morgan and Sean Hawkins. The Oxford History of the British Empire Companion Series. Oxford: Oxford University Press, 2004.

Ranger, T. O. "African Reaction to the Imposition of Colonial Rule in East and Central Africa." In The The History and Politics of Colonialism in Africa, Vol. I. Cambridge: Cambridge University Press, 1969.

Saunders, Christopher, and Iain R. Smith. "Southern Africa, 1795-1910." In The Oxford History of the British Empire: Volume III: The Nineteenth Century, edited by Andrew Porter. Oxford: Oxford University Press, 2001.

Tallie, T.J. "Racialised Masculinity and the Limits of Settlement: John Dunn and Natal, 1879-1883." Journal of Natal and Zulu History 30 (2012).

Wright, John. "Making the James Stuart Archive.” History in Africa 23 (January 1, 1996): $333-50$.

_. "Political Mythology and the Making of Natal's Mfecane." Canadian Journal of African 23, no. 2 (1989): 272-91.

\section{Unpublished papers and Dissertations}

Arndt, Jochen. "The Great Bifurcation: Missionary Linguistics and the Emergence of 'Xhosa' and 'Zulu' as Ethno- Linguistic Identities, 1820-1870." Unpublished paper presented at the ASA 2014, Panel: Identity and Violence, 2014.

Dominy, Graham Andrew. "The Imperial Garrison in Natal with Special Reference to Fort Napier 1843-1914: Its Social, Cultural and Economic Impact.” PhD Dissertation, University of London, 1995.

Mokoena, Hlonipha. "Anonymity and the Zulu Policeman : An Economy of Portraiture." WISER Seminar (Wits University), July 2013. 
Thompson, P. S. “'Loyalty's Fair Reward': The Natal Native Horse in the Zulu Rebellion of 1906." Unpublished paper presented at the ASA 2013, Panel: The Zulu Kingdom, Guns and Security of the Colonial State, November 23, 2013. 